\author{
Universidade de Brasília \\ Faculdade de Direito \\ Pós-graduação stricto sensu (Mestrado) \\ Dissertação de Mestrado
}

\title{
IGUAL CONSIDERAÇÃO E RESPEITO, INDEPENDÊNCIA ÉTICA E LIBERDADE DE EXPRESSÃO EM DWORKIN: \\ UMA RECONCILIAÇÃO ENTRE IGUALDADE E LIBERDADE E A POSSIBILIDADE DO DISCURSO DO ÓDIO EM UM ORDENAMENTO COERENTE DE PRINCÍPIOS
}

Autora: Ana Luiza Nuñez Ramalho Orientador: Prof. Dr. Menelick de Carvalho Netto

\author{
BRASÍLIA - DF \\ 2016
}


ANA LUIZA NUÑEZ RAMALHO

IGUAL CONSIDERAÇÃO E RESPEITO, INDEPENDÊNCIA ÉTICA E LIBERDADE DE EXPRESSÃO EM DWORKIN: UMA RECONCILIAÇÃO ENTRE IGUALDADE E LIBERDADE E A POSSIBILIDADE DO DISCURSO DO ÓDIO EM UM ORDENAMENTO COERENTE DE PRINCÍPIOS

Dissertação apresentada à Faculdade de Direito da Universidade de Brasília como requisito parcial para a obtenção do título de Mestre junto ao Departamento de Direito.

Orientador: Prof. Dr. Menelick de Carvalho Netto 
Ao João, por me resplandecer de um amor pleno, que celestialmente melhora com os anos, e que me convida ao reencontro cotidiano comigo mesma.

À Moema, minha mãe e companheira inseparável, retrato genuíno da espontaneidade e energia das terras cearenses, que emanam leite e mel, pela dedicação exemplar àqueles que ama, por me haver conduzido, pela mão, incondicionalmente. 
“(...) I disapprove of what you say, but I will defend to the death your right to say it."

- Evelyn Beatrice Hall-. 


\section{RESUMO}

Referência: RAMALHO, Ana Luiza Nuñez. Igual consideração e respeito, independência ética, e liberdade de expressão em Dworkin: Uma reconciliação entre igualdade e liberdade e a possibilidade do discurso do ódio em um ordenamento coerente de princípios. 2016. 184p. Dissertação de Mestrado. Faculdade de Direito da Universidade de Brasília.

O Estado Democrático de Direito é exigência da própria sociedade democrática moderna, que construiu, para si, uma comunidade de princípios, orientada pelo reinado da igualdade. Não obstante o resquício insistente do positivismo jurídico, o atual paradigma moderno, insuflado pelo excesso do Estado Social, aprendeu a lição herdada pelo mito da perfeição científica, pela crença no método heurístico, incapaz de regular a indeterminação imanente ao Direito. Com a virada principiológica, ganham destaque dois filósofos do Direito contemporâneo: Robert Alexy e Ronald Dworkin. A partir da leitura que cada um deles realiza acerca das regras e dos princípios e do lugar que ocupam os direitos fundamentais no cenário jurídico, de suas possibilidades de restrição e da adoção de uma teoria interna ou externa, encontram-se distinções cruciais que convidam a caminhos distintos. Por um lado, percebe-se, em Alexy, o apego à aplicação de um direito metodológico, amparado na perquirição de fórmulas matemáticas para a garantia de certezas. A perspectiva axiológica dos direitos alexiana e o uso da técnica da ponderação e da máxima da proporcionalidade acabam por tratar o Direito como ordem concreta de valores passíveis de gradação, realizáveis, na maior medida do possível. Por outro lado, a perspectiva deontológica dos direitos, à luz da Justiça de ouriços, considera o valor como algo muito importante, passível de uma lógica binária, e não gradual. A unidade do valor forma um tecido que se interliga através dos fios argumentativos construídos pela teoria de Dworkin. Esses fios percorrem cada caso concreto, que exige um esforço interpretativo capaz de levar os direitos a sério, atendendo ao verdadeiro sentido de que o homem possui trunfos contra o Estado. Para isso, Dworkin sugere o reinado dos princípios da igual consideração e respeito, de onde fluem as liberdades, e do respeito às responsabilidades que cada cidadão possui para a escolha de questões essenciais - o respeito à independência ética. Nesse cenário, igualdade e liberdade se pressupõem, na medida em que, se uma liberdade é exigência da igualdade, então essa liberdade constitui um direito forte, um verdadeiro trunfo. Destarte, as liberdades são medidas pelo respeito à independência ética. Aborda-se a incômoda questão do discurso do ódio, defendendo-se que essa modalidade de expressão da liberdade encontra respaldo enquanto direito-trunfo pressuposto do igual tratamento e do respeito à independência ética. Assim, a teoria da liberdade dworkineana agasalha o direito dos detestáveis, e rechaça argumentos utilitaristas, que ilusoriamente contêm um matiz igualitário. Faz-se imperiosa a distinção entre argumentos de política e argumentos de princípio. O cenário jurídico brasileiro, no entanto, e, especialmente no emblemático caso Ellwanger, proíbe o discurso do ódio, por considerá-lo racista e discriminatório. Portanto, o contexto histórico-institucional optou por traçar a tênue linha divisória entre o discurso do ódio e as leis antidiscriminatórias um pouco antes do respeito à independência ética, um pouco antes da configuração real, fática, concreta e iminente de uma prática discriminatória. À luz da teoria dworkineana, isso configuraria um erro, pois o Estado censurou uma voz que tem direito à igualdade, e que merece respeito, ainda que detestável, ao menos que ela configurasse, além do plano das ideias impressas nas folhas de papel, um perigo grave, real, concreto e iminente. Vale refletir se nosso contexto está preparado para ressignificar a liberdade de expressão nos tempos de hoje.

Palavras-chave: Igual consideração e respeito; liberdade de expressão; independência ética; discurso do ódio; Dworkin; método; Alexy; Ellwanger. 


\begin{abstract}
The democratic rule of law is required by modern democratic society. This society has built a community of principles, guided by the reign of equality. Despite the persistence of legal positivism in some circles, the current legal scene has a new paradigm. It is a product of the lessons learned from the mistakes of the welfare state and the myth of scientific perfection (which is totally unfit to deal with law's inherent indeterminacy). After this paradigm shift based on the idea of principles, two contemporary philosophers of law have gained preeminence: Robert Alexy and Ronald Dworkin. Each one of them has reached crucially different conclusions, based on distinctions concerning rules and principles, the role of fundamental rights in the legal landscape, and the adoption of the external or the internal theory of rights. On one side, Alexy strives to find certainty, based in mathematical formulas and attachment to a rigorous methodology. Alexy's view and his use of balancing and proportionality assume that law is a system of values to be realized to the greatest extent possible, given the legal and factual possibilities. On the other side, the deontological view of rights, in light of a justice for hedgehogs, holds that values, because of their extreme importance, should be treated in a binary manner, and not in degrees. The unity of value constitutes a fabric that is intertwined with argumentative threads, just like in Dworkin's theory. These threads encompass each concrete case, which requires an interpretative effort capable of taking rights seriously. That is the true meaning of an individual having trumps against the Government. That is why Dworkin proposes a reign of principles of equal respect and concern. Every citizen is empowered by liberties - also arising from his responsibilities that demand respect for his ethical independence. In this context, equality and freedom presuppose one another, because, if a freedom is required by equality, then that freedom constitutes a strong right, a real trump. Therefore, freedoms are measured by the respect to ethical independence. The problem of hate speech can be settled in the following way: hate speech should be defended, because the freedom of speech is a right (and a trump) based on equal treatment and on the respect to one's ethical independence. Thus, Dworkin's theory of freedom protects the right of contemptible speech and sets aside utilitarian arguments, which only deceptively abide by equality. It is pivotal to differentiate arguments of policy and of principle. Nevertheless, the Brazilian legal systems, especially after the Ellwanger case, has banned hate speech, considering it racist and discriminating. Hence, the current legal system has chosen to draw a line between hate speech and anti-discrimination laws a little before ethical independence requires (a little before an actual and concrete act of discrimination takes place). In light of Dworkin's theory, that would be a mistake, since the Government has censured an opinion that, notwithstanding its despicable nature, deserves respect, because of the right to equality. The only exception would be if, beyond the mere expression of ideas, a clear and present danger was imminent. It is necessary to consider if our current system is prepared to give a new meaning to freedom of speech today, one that is compatible with the idea of equal respect and concern.
\end{abstract}

Keywords: equal respect and concern; freedom of speech; ethical independence; hate speech; Dworkin; method; Alexy; Ellwanger. 


\section{SUMÁRIO}

INTRODUÇÃO. 8

\section{PARTE I:}

Limitação aos direitos fundamentais em um sistema vivo de regras e princípios: a problemática trazida pelas teorias interna e externa dos direitos fundamentais

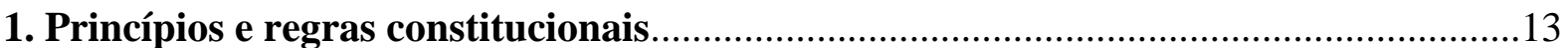

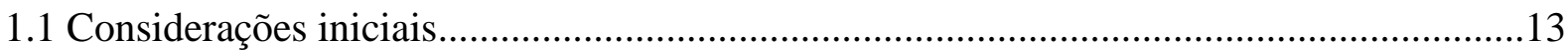

1.2 Principais critérios de distinção entre princípios e regras ................................................16

1.2.1 Ronald Dworkin - The Model of Rules (all or nothing)

e o ordenamento principiológico 19

1.2.2 Robert Alexy - princípios como mandamentos de otimização ..................................22

1.2.3 Contribuições da literatura jurídica brasileira ...........................................................26

2. Qual é a contribuição das regras e dos princípios para o sistema constitucional?.......30

2.1 A Constituição como sistema aberto de regras e princípios .............................................30

2.2 A essencialidade dos princípios diante da construção de uma identidade constitucional: a complexa tensão entre inclusão e exclusão e a abertura para a afirmação de direitos fundamentais como a igualdade e a liberdade.

3. Colisão entre normas constitucionais: quais os limites dos direitos fundamentais?.....37

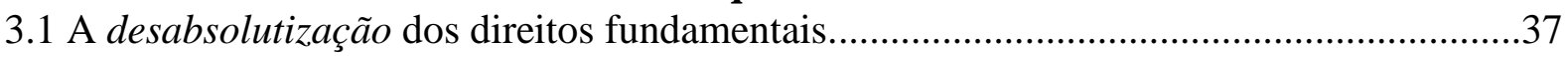

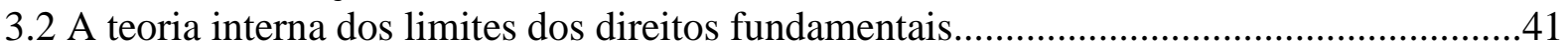

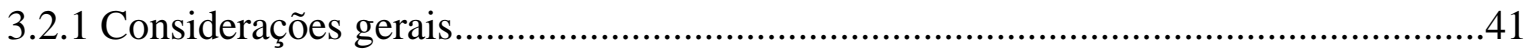

3.2.2 Principais críticas à teoria interna dos limites dos direitos fundamentais....................47

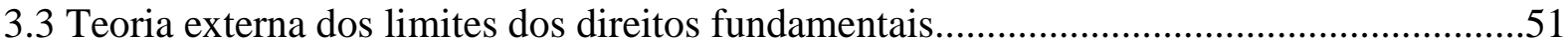

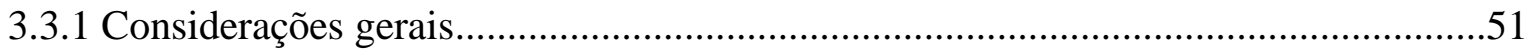

\section{PARTE II:}

O Direito como método em Alexy versus o Direito principiológico em Dworkin.

1. Alexy: o Direito como método

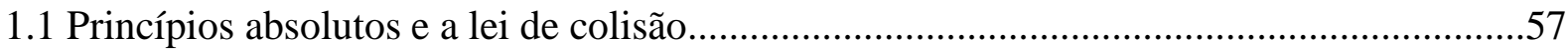

1.2 A dignidade humana em Alexy e suas duas normas: a regra absoluta

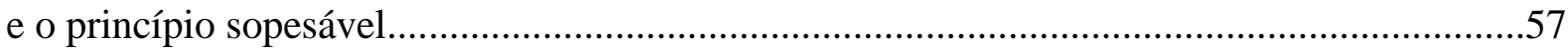

1.3 Princípios: Um conceito amplo. Direitos individuais e direitos coletivos.........................60

1.4 A teoria alexiana dos princípios e a máxima da proporcionalidade.................................61

1.5 A inaceitabilidade do modelo puro de princípios e do modelo puro de regras...................64

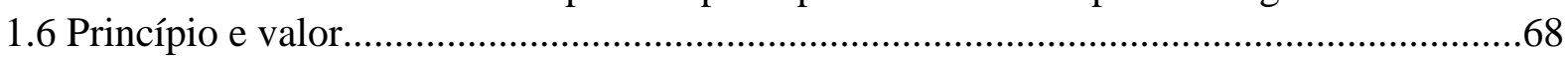

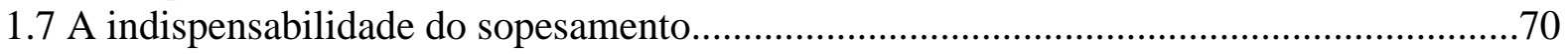

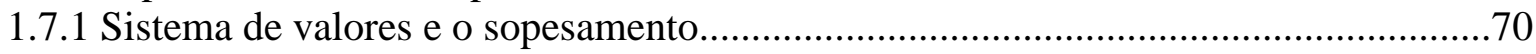

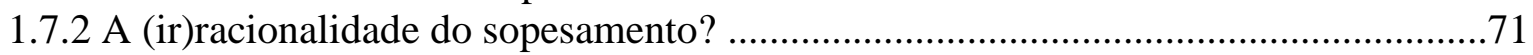

1.7.3 O modelo de sopesamento baseado na teoria dos princípios de Alexy .......................73

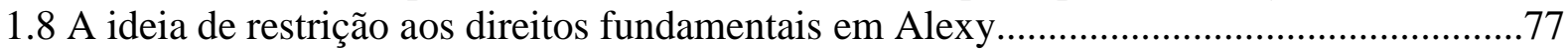

1.8.1 A possibilidade de restrições aos direitos fundamentais...................................78

1.8.2 A garantia do conteúdo essencial dos direitos fundamentais...........................82 


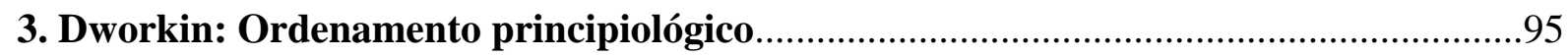

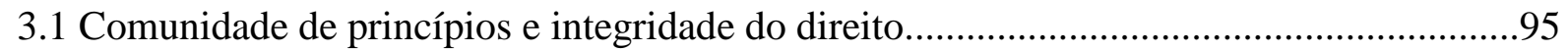

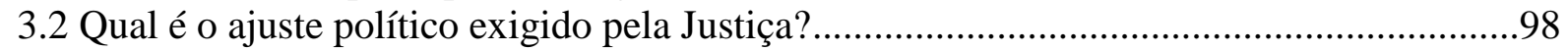

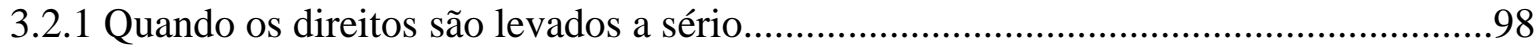

3.2.2 Uma crítica aos argumentos utilitaristas e aos seus benefícios especulativos. O perigo das maiorias?

3.2.3 O que é um direito em sentido forte? A ideia de direitos fundamentais como trunfos

\section{PARTE III:}

O discurso do ódio e os postulados da igual consideração e respeito e da liberdade de expressão. Uma análise do caso Ellwanger.

1. Liberdade e igualdade: princípios que se reforçam

1.1 Qual é o ponto de encontro entre os conceitos de igualdade e de liberdade?...................109

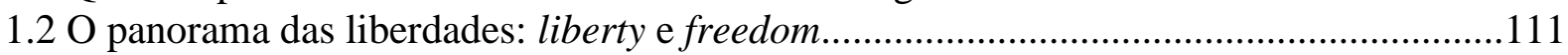

1.3 Ethical independence para uma melhor compreensão da liberdade ................................113

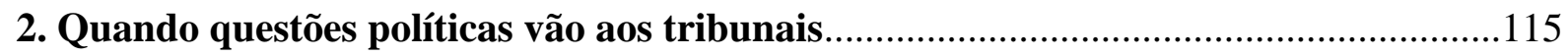

2.1 Como decidem os tribunais?

A atividade interpretativa do juiz e a tese da única decisão correta.

2.2 Qual lugar ocupa o direito à livre expressão?

Liberdade de expressão e o hate speech.............................................................................122

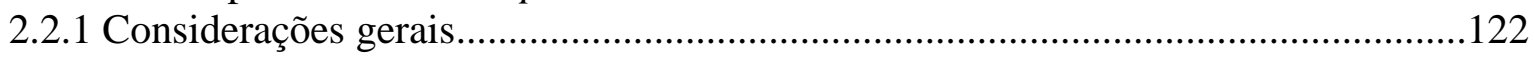

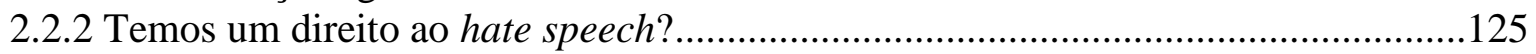

2.2.3 O caso Estados Unidos versus Snepp:

Os apelos ao bem-estar geral atraem a censura

3. Liberdade de expressão no cenário brasileiro:

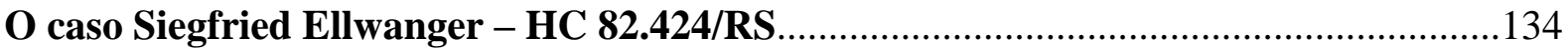

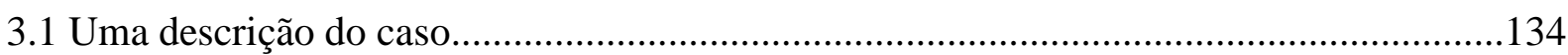

3.2 O caminho perquirido pelo STF rumo à decisão: o apelo ao método...............................140

3.3 A decisão do STF atendeu a exigência de se levar os direitos a sério?

É possível a reconciliação entre liberdade e igualdade no discurso do ódio?

Leis antidiscriminatórias convivem com a liberdade de expressão em um cenário de inclusão de minorias?.

3.3.1 Liberdade de expressão restringida: a impossibilidade do

discurso do ódio no cenário jurídico brasileiro.

3.3.2 Uma abertura à possibilidade do discurso do ódio em nosso contexto.

4. Hitler censurado: A decisão brasileira que ordenou o recolhimento do livro "Mein Kampf" 


\section{INTRODUÇÃO}

O presente estudo pretende convidar o leitor a uma reflexão orientada pela teoria dos direitos proposta pelo jusfilósofo americano Ronald Dworkin, acerca do desconfortante tema do discurso do ódio. Pretendemos demonstrar como se entrelaçam, coerentemente, os fios argumentativos da teoria dworkineana, regida pela importância do valor, o que desemboca na única decisão correta, enquanto exigência de que os direitos sejam levados a sério.

A Parte I deste trabalho constitui momento inicial e localizador, abordando os principais critérios de distinção traçados pela literatura jurídica entre regras e princípios constitucionais, conferindo-se especial destaque às considerações trazidas por Ronald Dworkin $^{1}$ e por Robert Alexy $^{2}$, que, embora tenham realizado uma leitura que nos convida a rumos distintos na aplicação do Direito, propiciaram a chamada virada principiológica, exigida pela sociedade democrática moderna. Destacamos o "model of rules" e o ordenamento principiológico apresentado por Dworkin, onde até mesmo as regras são principiologicamente lidas, enquanto densificação da comunidade de princípios construída pela sociedade. Destacamos, também, a perspectiva alexiana dos princípios enquanto mandamentos de otimização, realizáveis na maior medida possível sob determinada condição. Abordamos a necessidade de uma leitura principiológica diferenciada diante da construção de uma identidade constitucional, perplexamente constituída pela tensão entre inclusão e exclusão, que busca a abertura para a afirmação de direitos fundamentais como a igualdade e a liberdade. Para isso, utilizamo-nos das lições de autores que encorpam a linha do direito constitucional contemporâneo sectária do liberalismo defendido por John Rawls e por Ronald Dworkin, como Michel Rosenfeld ${ }^{3}$ (The identity of the constitutional subject), que, por sua vez, realiza uma análise em torno da natureza evasiva do sujeito constitucional e da busca pela identidade constitucional, e pelo equilíbrio entre o "eu" e o "outro". Demonstramos, sob o reforço da ótica habermasiana ${ }^{4}$, a importância do postulado da igualdade no cenário que busca a inclusão das minorias, uma vez que é inegável que a inclusão dos indivíduos

\footnotetext{
${ }^{1}$ Cf. DWORKIN, Ronald. Taking Rights Seriously. Cambridge: Harvard University Press, 1977; DWORKIN, Ronald. A Matter of Principle. Cambridge: Harvard University Press, 1985; DWORKIN, Ronald. Law's Empire. Cambridge: Harvard University Press, 1986; DWORKIN, Ronald. Justice for Hedgehogs. Cambridge: The Belknap Press, 2011.

${ }^{2}$ Cf. ALEXY, Robert. Teoria dos Direitos Fundamentais (2 ${ }^{\mathrm{a}}$ ed.). Tradução de Virgílio Afonso da Silva da $5^{\mathrm{a}}$ edição alemã Theorie der Grundrechte. São Paulo: Malheiros Editores, 2009.

${ }^{3}$ Cf. ROSENFELD, Michel. A identidade do sujeito constitucional. Texto original: The identity of the constitutional subject. In: Cardoso Law Review: A Mentalidade Pós-Moderna e o Direito, Nova Iorque: Yeshiva University Press, p. 1049-1109, Janeiro de 1995. Copyright: Yeshiva University e Michel Rosenfeld.

${ }^{4}$ Cf. HABERMAS, Jürgen. Notas sobre a tríade de Denninger: diversidade, segurança e solidariedade.
} 
pressuponha o igual acesso a relações e a tradições sociais constitutivas-de-identidade. Posteriormente, instigados pela compreensão do alcance dos direitos fundamentais, adentramos nas principais características das teorias interna e externa dos limites dos direitos fundamentais, momento em que assentamos nossa compreensão ao afirmar que o Direito moderno não é solucionado tão somente com a edição de normas, na medida em que requer a aplicação adequada de normas gerais e abstratas aos casos individualizados e concretos, dotados de unicidade e de irrepetibilidade. Percebemos, assim, que a complexidade do Direito pressupõe irmos além da edição de normas. Considerar o caráter de unicidade em cada caso é reflexo de um alerta diante de pretensões abusivas, que podem travestir-se por trás das normas. Dessa forma, acreditamos que a adoção da teoria interna é adequada para atender à proposta de integridade no Direito.

Ao adentrarmos na Parte II deste estudo, pretendemos realizar um contraponto entre o Direito enquanto método adotado por Robert Alexy e o Direito principiológico defendido por Dworkin. Para isso, iniciamos com a superação da ideia de absolutização de princípios e a conseguinte possibilidade do estabelecimento da lei de colisão pela doutrina alexiana. Prosseguimos com a abordagem alexiana, acerca da dignidade humana enquanto concepção que envolve duas normas - a regra absoluta impressa pela letra da lei, e o princípio, sopesável. Mais uma vez, realizamos uma contraposição entre Alexy e Dworkin. Este compreende a dignidade humana enquanto trunfo contra o Estado, não sendo passível de sopesamento, uma vez que é exigência da igual consideração e respeito e do respeito às responsabilidades pessoais de cada cidadão, compondo um padrão "genuinamente universal"5. Em seguida, retomamos a teoria alexiana dos princípios e a máxima da proporcionalidade, a concepção alexiana de princípios enquanto valor, e chegamos até a técnica do sopesamento, indispensável na teoria dos direitos fundamentais de Alexy. Explicitamos o sistema de valores e o sopesamento, expusemos as principais críticas ao sopesamento, e a réplica de Alexy a essas críticas, intentando comprovar sua racionalidade mediante uma apresentação metodológica do Direito. A lei do sopesamento, válida para todos os tipos de sopesamento de princípios, é fruto do apego metodológico alexiano, que extrai a cláusula "dentro das possibilidades jurídicas" do próprio conceito de princípios, verificando que "aquilo que é exigido por um princípio foi inserido em uma relação com aquilo que é exigido pelo princípio

\footnotetext{
${ }^{5}$ DWORKIN, Ronald. A raposa e o porco-espinho: justiça e valor. Tradução de Marcelo Brandão Cipolla. São Paulo: Editora WMF Martins Fontes, 2014, p. 507-517.
} 
colidente". ${ }^{6}$ Demonstramos como o jusfilósofo alemão recorre a técnicas matemáticas para embasar os pesos de princípios. Enunciamos também decisões da jurisprudência reiterada do Tribunal Constitucional Federal alemão, em consonância com as perspectivas teóriconormativas e de fundamentação da teoria dos princípios de Robert Alexy. ${ }^{7}$ Em seguida, abordamos a ideia de restrição aos direitos fundamentais em Alexy, assim como a garantia do conteúdo essencial dos direitos fundamentais para o referido doutrinador.

Após uma insistente exposição da teoria dos direitos fundamentais de Alexy, explicitamos nossas razões para rechaçar a concepção de um Direito metodológico. Destarte, a recorrência a um método heurístico supostamente garantidor de certezas leva a teoria alexiana a um resultado de aplicação prática que nem sempre atenderá ao respeito de direitos enquanto trunfos. Elucidamos como a perspectiva axiológica dos direitos, o uso da técnica do sopesamento e da máxima da proporcionalidade trata o Direito como uma ordem concreta de valores passíveis de gradação. É neste momento que nos valemos da citação do dramaturgo grego Arquíloco, segundo o qual "a raposa sabe muitas coisas, e o ouriço sabe uma só, mas o que o ouriço sabe é muito importante", ideia originária do termo Justiça de ouriços, utilizada por Dworkin na sustentação da tese principal da unidade do valor. A Justiça de ouriços é formada por fios argumentativos estruturalmente coerentes, que respeita a lógica binária do Direito, que não é passível de gradações. Apontamos, assim, que a leitura alexiana convida os direitos fundamentais a caírem em uma análise de custos e vantagens, confundindo-os com determinações de objetivos, a saber, com argumentos de política.

Ao final da Parte II, iniciamos os nossos esforços para uma melhor compreensão da teoria dworkineana, que afirma uma comunidade de princípios, complexamente formada e reciprocamente constitutiva, onde os direitos ganham validade deontológica, sinalizando a averiguação das únicas decisões corretas. A interpretação holística, orientada pela noção maior de integridade, insiste que a decisão judicial seja uma questão de princípio, e não um compromisso de estratégica política. Buscamos responder qual é o ajuste político exigido pela justiça, a partir da compreensão do que é levar os direitos a sério. Tecemos uma crítica aos argumentos utilitaristas, e analisamos qual é o perigo que as maiorias podem impingir sobre nossas vidas. Posteriormente, apresentamos a concepção dworkineana de direitos

\footnotetext{
${ }^{6}$ ALEXY, Robert. Teoria dos Direitos Fundamentais, 2. ed., Tradução de Virgílio Afonso da Silva da 5 a edição alemã Theorie der Grundrechte. São Paulo: Malheiros Editores, 2009, p. 131.

${ }^{7}$ ALEXY, Robert. Teoria dos Direitos Fundamentais, 2. ed., Tradução de Virgílio Afonso da Silva da $5^{a}$ edição alemã Theorie der Grundrechte. São Paulo: Malheiros Editores, 2009, p. 131 Cf., por exemplo, BVerfGE 19330 (337); 21, 150 (155); 26, 215 (228); 27, 211 (219); 30, 292 (316).
} 
fundamentais fortes, que compõem os chamados trunfos que o cidadão possui contra o Estado.

Por sua vez, sob o título "O discurso do ódio e os postulados da igual consideração e respeito e da liberdade de expressão. Uma análise do caso Ellwanger”, a Parte III do nosso trabalho dedica-se à análise da permissibilidade do discurso do ódio e da existência de leis antidiscriminatórias, em um mesmo cenário, de modo que ambos configurem exigência do reinado da igual consideração e respeito. Para isso, iniciamos com a ideia de que igualdade e liberdade são concepções que se complementam, de modo que um Estado que leve os direitos a sério é regido pela obediência ao postulado da igual consideração e respeito, assim como ao respeito à independência ética. Propõe-se a compreensão da lógica estrutural da teoria dos direitos sugerida por Dworkin: uma liberdade merece configurar a concepção de trunfo se ela for necessária para que um cidadão seja considerado como igual. E as margens dessa liberdade-trunfo-decorrente-da-igualdade serão traçadas pela independência ética, que, por sua vez, envolve o respeito às escolhas de questões essenciais concernentes à vida do cidadão.

Após analisar o reinado da igualdade, da liberdade e da independência ética em Dworkin, adentramos na atividade interpretativa jurisdicional, orientada por argumentos de princípio, e não de política, rumo à decisão correta. Em seguida, mergulhamos na polêmica questão do discurso do ódio. Temos um direito ao hate speech? À luz da teoria dworkineana, não somente temos um direito ao discurso do ódio, decorrente do trunfo da liberdade de expressão, como também somos insultados quando o Estado censura esse direito, ao menos que esteja na presença de um perigo grave, real e iminente. Dessa forma, o hate speech não deve ser censurado com base em argumentos de riscos especulativos em prol da utilidade geral. Se isso acontece, então se está emprestando as cores da política a um princípio, o que retira o próprio sentido de um trunfo.

Finalmente, perpetramos o emblemático caso Ellwanger. Após uma breve descrição do caso, analisamos o caminho perquirido pelo nosso Supremo Tribunal Federal para chegar à manutenção condenatória do editor Siegfried Ellwanger por crime de racismo. Verificamos que nosso tribunal utilizou-se da técnica da ponderação e do princípio da proporcionalidade, que levaram os Ministros Gilmar Mendes e Marco Aurélio a resultados diametralmente opostos. Reafirmamos nossas críticas à aplicação metodológica do Direito. Não obstante a questão inicial abordada pelos nossos ministros tenha sido a lamentável questão de se os judeus configurariam uma raça, o que nos levaria à conclusão paradoxal de que o racismo seria crime impossível, uma vez que raça, geneticamente, inexiste, a questão central foi a leitura que nosso cenário jurídico institucional realiza acerca da liberdade de expressão. 
Mencionamos também a decisão brasileira que ordenou o recolhimento do livro "Mein Kampf', de autoria de Adolf Hitler.

Convidamos o leitor a uma reconciliação entre liberdade e igualdade, entre leis antidiscriminatórias e liberdade de expressão do ódio, sem que isso implique em um esvaziamento dessas concepções. Propomos traçar a linha que divide o discurso do ódio e a existência de leis contra crimes raciais para além do discurso do ódio, para além do respeito à independência ética, de modo que esse discurso venha a ser censurado somente em casos concretos, fáticos e iminentes. Isso porque tanto o discurso do ódio como as leis antidiscriminatórias são exigência de uma sociedade que trate os cidadãos enquanto iguais, e que proteja o livre acesso a todos, sem distinções.

Direcionamos nossos esforços para que o leitor possa despir-se de juízos passionais, pois sabemos o quão detestável é o discurso do ódio. Contudo, não podemos considerar um homem menos que um homem nem negar-lhe o direito à voz igual porque essa voz é nefasta e maldosa. Não temos o direito de invadir a porção da autonomia ética desses detestáveis. Almejamos, ainda que cientes do peso de nossa tradição histórica, contribuir para o debate em torno da possibilidade de ressignificação da livre expressão por nosso paradigma moderno. 


\section{PARTE I - LIMITAÇÃO AOS DIREITOS FUNDAMENTAIS EM UM SISTEMA VIVO DE REGRAS E PRINCÍPIOS: A PROBLEMÁTICA TRAZIDA PELAS TEORIAS INTERNA E EXTERNA DOS DIREITOS FUNDAMENTAIS}

\section{PRINCÍPIOS E REGRAS CONSTITUCIONAIS}

\subsection{CONSIDERAÇÕES INICIAIS}

A classificação das normas constitucionais que as distingue em princípios e regras é bastante discutida pela doutrina contemporânea.

Ao referir-se a três fases de normatividade, Paulo Bonavides tece uma reconstrução da trajetória histórica dos princípios. A primeira fase corresponde ao predomínio do jusnaturalismo, onde os princípios eram encarecidos no plano moral, e concebidos como postulados de justiça. Todavia, nessa fase, a natureza dos princípios não era reconhecida como propriamente normativa. Já na segunda fase, onde predominava o positivismo jurídico, os princípios também não eram reconhecidos como normas, mas como meios de integração do Direito. Aqui, os princípios são considerados como imanentes ao ordenamento jurídico, ao invés de transcendentes a ele, e a sua construção dava-se mediante um processo de abstração que extraía do próprio sistema jurídico as suas principais orientações. Por sua vez, a fase atual, correspondente ao pós-positivismo, teria como característica central a valorização dos princípios, perpassando a dimensão ético-moral até o plano propriamente jurídico. É neste período que os princípios ganham significativo realce, por reluzirem uma "hegemonia axiológica", tendo em vista que se converteram em "pedestal normativo sobre o qual assenta todo o edifício jurídico dos novos sistemas constitucionais". ${ }^{8}$

Sabemos que o positivismo não acarreta em uma incompatibilidade conceitual frente ao reconhecimento da normatividade dos princípios jurídicos, desde que devidamente positivados. Entretanto, de acordo com Daniel Sarmento e Cláudio Pereira de Souza, "as versões do positivismo que lograram maior penetração no cotidiano do Direito, pelo menos no Brasil, não reservavam um lugar de honra para os princípios". 9

Devido ao receio de que a operacionalidade do modelo positivista-legalista fosse comprometida pela possível aplicação direta de normas tão abertas como os princípios, estes

\footnotetext{
${ }^{8}$ BONAVIDES, Paulo. Curso de direito constitucional. 8. ed. São Paulo: Malheiros, 1999, p. 232-238.

${ }^{9}$ SOUZA NETO, Cláudio Pereira de; SARMENTO, Daniel. Direito Constitucional: Teoria, história e métodos de trabalho. 2. ed. Belo Horizonte: Fórum, 2014, p. 380.
} 
não eram vistos com bons olhos pelo positivismo legalista com todo o seu método baseado na subsunção e na negação da dimensão constitutiva da interpretação jurídica. ${ }^{10}$

O normativismo, que encontrou inspiração em Hans Kelsen, tampouco apostava nos princípios, uma vez que considerava a vagueza das normas jurídicas uma simples autorização para a discricionariedade judicial na criação do Direito. Para Kelsen, a aplicação do Direito envolve sempre uma escolha política do intérprete, "no âmbito definido pela moldura da norma aplicada. No interior desta moldura, não há resposta certa ou errada, mas pura discricionariedade". ${ }^{11}$

Os princípios obtiveram sua normatividade reconhecida paralelamente à crise do positivismo jurídico, após a II Guerra Mundial, período de eminência de constituições predominantemente principiológicas, que contavam com encorpados mecanismos de controle jurisdicional de constitucionalidade. Nesse ínterim,

\section{A tendência, estimulada pela jurisdição constitucional, foi no sentido do paulatino reconhecimento de que todas as normas constitucionais eram normas jurídicas, inclusive os princípios mais indeterminados, antes vistos como meras proclamações políticas. ${ }^{12}$}

Há não muito tempo, no Brasil, prevalecia a concepção legalista do positivismo, onde os princípios jurídicos não eram considerados propriamente normas, sendo reduzidos a meros instrumentos para integração de lacunas, aos quais o intérprete socorrer-se-ia em situações excepcionais.

Esse entendimento está positivado no artigo $4^{\circ}$ da atualmente denominada Lei de Introdução às Normas do Direito Brasileiro: "Quando a lei for omissa, o juiz decidirá o caso de acordo com a analogia, os costumes e os princípios gerais de direito". Portanto, os princípios constituíam mera fonte subsidiária do Direito. ${ }^{13}$ Nos dias atuais, a doutrina e a jurisprudência realizam uma leitura diferente em relação a esse dispositivo. Devido à força normativa dos princípios, o artigo $4^{\circ}$ da LINDB sofreu uma releitura, sendo que a "lei" abrange tanto as regras como os princípios jurídicos, que são distintos dos princípios mencionados no artigo em comento, de forma que estes aludem a princípios meramente

\footnotetext{
${ }^{10}$ SOUZA NETO, Cláudio Pereira de; SARMENTO, Daniel. Direito Constitucional: Teoria, história e métodos de trabalho. 2. ed. Belo Horizonte: Fórum, 2014, p. 380.

${ }^{11}$ KELSEN, Hans. Teoria pura do direito, 5.ed., p. 463-473 apud SOUZA NETO, Cláudio Pereira de; SARMENTO, Daniel. Direito Constitucional: Teoria, história e métodos de trabalho. 2. ed. Belo Horizonte: Fórum, 2014, p. 380.

${ }^{12}$ SOUZA NETO, Cláudio Pereira de; SARMENTO, Daniel. Direito Constitucional: Teoria, história e métodos de trabalho. 2. ed. Belo Horizonte: Fórum, 2014, p. 380.

${ }^{13}$ SOUZA NETO, Cláudio Pereira de; SARMENTO, Daniel. Direito Constitucional: Teoria, história e métodos de trabalho. 2. ed. Belo Horizonte: Fórum, 2014, p. 380.
} 
informativos ou gerais ${ }^{14}$, compondo meros conselhos, recomendações, e usados em segundo plano pelo intérprete. $^{15}$

Dessa forma, o ordenamento jurídico brasileiro tem enfatizado não somente a força normativa dos princípios, mas também sua máxima relevância, especialmente os constitucionais. Inclusive, essa relevância passa a ser objeto de críticas severas, devido aos supostos excessos cometidos nesta área, "que culminam numa equivocada desvalorização das regras jurídicas", e num uso "muitas vezes pouco racional e fundamentado da principiologia constitucional", no "uso e abuso de princípios"16, ocasionando o fenômeno denominado euforia dos princípios. ${ }^{17}$

A partir da década de 90, as lições trazidas por dois grandes filósofos do Direito contemporâneos - Ronald Dworkin e Robert Alexy -, propiciaram a virada principiológica na literatura jurídica brasileira. Não obstante tenham apresentado uma teoria dos direitos com base em fundamentos especialmente distintos, ambos autores teceram diferenças qualitativas, e não meramente quantitativas entre as regras e os princípios. Não há que se olvidar de autores brasileiros como Celso Antônio Bandeira de Mello ${ }^{18}$ e Geraldo Ataliba ${ }^{19}$, que conferiram aos princípios notável valorização antes mesmo da chamada virada principiológica.

No entanto, foi somente a partir da década de 90 que a doutrina brasileira sofreu a enxurrada do tema princípios constitucionais. Vale destacar autores como Paulo Bonavides ${ }^{20}$, Eros Roberto Grau ${ }^{21}$, Humberto Ávila ${ }^{22}$, Ana Paula de Barcellos ${ }^{23}$, Jane Reis Gonçalves Pereira $^{24}$, Virgílio Afonso da Silva ${ }^{25}$, Ruy Samuel Espíndola ${ }^{26}$.

\footnotetext{
${ }^{14}$ Os princípios informativos ou gerais do sistema compreendem: não lesar a ninguém; dar a cada um o que é seu; viver honestamente.

${ }^{15}$ Cf. FARIAS, Cristiano Chaves de; ROSENVALD, Nelson. Curso de Direito Civil. Parte Geral e LINDB. Vol. 1. 13. ed. 2015.

${ }^{16}$ Expressão advinda da doutrina de Marcelo Neves. Cf. NEVES, Marcelo. Entre Hidra e Hércules: princípios e regras constitucionais como diferença paradoxal do sistema jurídico. São Paulo: Editora WMF Martins Fontes, 2013, p. 171 e ss.

${ }^{17}$ SARMENTO, Daniel. Ubiquidade constitucional: os dois lados da moeda. In: SARMENTO, Daniel. Livres e iguais: estudos de direito constitucional, p. 198-204; BARCELLOS, Ana Paula de. O direito constitucional em 2006. Revista de Direito do Estado, n. 5, p. 3-23.

${ }^{18}$ BANDEIRA DE MELLO, Celso Antônio. Elementos de direito administrativo. São Paulo: Revista dos Tribunais, 1986.

${ }^{19}$ ATALIBA, Geraldo. República e Constituição. São Paulo: Malheiros, 1985.

${ }^{20}$ Cf. BONAVIDES, Paulo. Curso de direito constitucional. 8. ed. São Paulo: Malheiros, 1999.

${ }^{21}$ Cf. GRAU, Eros Roberto. A ordem econômica na Constituição de 1988: interpretação e crítica, 2. ed. São Paulo: Revista dos Tribunais, 1990.

${ }^{22}$ Cf. ÁVILA, Humberto. Teoria dos princípios. 11.ed. São Paulo: Malheiros, 2010.

${ }^{23}$ Cf. BARCELLOS, Ana Paula de. A eficácia jurídica dos princípios constitucionais: o princípio da dignidade da pessoa humana. Rio de Janeiro: Renovar, 2002.

${ }^{24}$ Cf. PEREIRA, Jane Reis Gonçalves. Interpretação constitucional e direitos fundamentais. Rio de Janeiro: Renovar, 2006.
} 
Esse contexto permitiu a ressignificação dos direitos fundamentais, tendo em vista que cada geração logrou revisitar o passado, emprestando-lhe novas cores, enquanto clamava por desafios futuros.

Não obstante o positivismo tenha-se apegado ao método em busca da segurança que este poderia oferecer-lhe, acreditamos que isso representou o maior dos mitos: a crença em um método heurístico.

Contudo, vale perpassar, neste trabalho, os caminhos trilhados rumo à melhor compreensão acerca das regras e dos princípios, para, posteriormente, colher o entendimento da real leitura que eles exigem pelo ordenamento jurídico.

\title{
1.2 PRINCIPAIS CRITÉRIOS DE DISTINÇÃO ENTRE PRINCÍPIOS E REGRAS
}

Primeiramente, vale asseverar que constituem o conceito de norma tanto as regras como os princípios, uma vez que indicam o dever-ser. Ainda que de espécie bastante distinta, os princípios, assim como as regras, são razões para juízos concretos de dever-ser. Portanto, a distinção entre regras e princípios é uma distinção entre duas espécies de normas. ${ }^{27}$

Antes de mais nada, a doutrina moderna confere ênfase ao fato de que a distinção entre princípios e regras ocorre no plano das normas jurídicas, e não no dos respectivos textos, o que, de forma alguma, implicaria na insignificância destes.

Em breves considerações, é preciso deixar claro que texto não se confunde com norma. ${ }^{28} \mathrm{~A}$ importância do texto não é esvaziada pelo fato de ele não ser norma. De acordo com os anúncios da hermenêutica filosófica, Gadamer ${ }^{29}$ esclarece:

\begin{abstract}
(...) o papel do hermeneuta é deixar o outro falar em sua alteridade doadora de sentido: no campo do Direito, o processo de desvelamento significa acima de tudo que o sujeito intérprete não pode contaminar o processo interpretativo com suas idiossincrasias, isto é, com seus pré-juízos inautênticos e individuais. E é na fusão de horizontes da dimensão ôntica do texto com a ontológica da existência que a norma (e, logo, a determinação de seu conteúdo) deve emergir. ${ }^{30}$
\end{abstract}

\footnotetext{
${ }^{25}$ Cf. SILVA, Virgílio Afonso da. Princípios e regras: mitos e equívocos acerca de uma distinção. In: Revista Latino Americana de Estudos Constitucionais, n. 1, 2003.

${ }^{26}$ Cf. ESPÍNDOLA, Ruy Samuel. Conceito de princípios constitucionais: elementos teóricos para uma formulação dogmática adequada. 1999.

${ }^{27}$ ALEXY, Robert. Teoria dos Direitos Fundamentais (2a ed.). Tradução de Virgílio Afonso da Silva da $5^{\mathrm{a}}$ edição alemã Theorie der Grundrechte. São Paulo: Malheiros Editores, 2009, p. 87.

${ }^{28}$ Essa tese já foi demonstrada por Hans Kelsen - quando trata da proposição jurídica em sua Teoria Pura do Direito -, por Franco Cordero e Friederich Müller. Entre a doutrina brasileira, destaque-se Jacinto Coutinho, Lenio Streck, Alexandre Rosa e muitos outros.

${ }^{29}$ GADAMER, Hans-George. Verdad y Método. Tradução por Ana Agud Aparicio y Rafael de Agapino. Salamanca: Sígueme, 1977. p. 414.

${ }^{30}$ MARRAFON, Marco Aurélio. Texto constitucional não é norma, mas vincula. Disponível em: <http://www.conjur.com.br/2015-dez-28/constituicao-poder-texto-constitucional-nao-norma-vincula >. Acesso em 3 jan. 2016.
} 
Se a linguagem tem o seu caráter instrumental eliminado, em prol de sua historicidade e centralidade operada com a guinada linguística, resta demonstrado que "a lógica formal não fornece um acesso pleno ao sentido do ente (no caso, a própria estrutura do sistema jurídico e seus textos normativos)". Dessa forma, a lógica formal "não dá conta do logos hermenêutico inerente ao mundo prático, doador de sentidos existencialmente compartilhados", tampouco contempla a possibilidade - sempre real e iminente -, "de que o sentido seja antecipado por meio de um giro metafórico ou metonímico provenientes do inconsciente". ${ }^{31}$

Assim, no fenômeno jurídico, a diferença entre texto e norma é ontológica, de modo que o texto é ente, e a norma expressa o "ser", e "ente não existe como ente, pois só ganha existência quando internalizado". ${ }^{32}$ Todavia, quando isso ocorre, o texto expressa sua capacidade de promover a reorganização do universo compreensivo e, portanto, de gerar novos sentidos. ${ }^{33}$

Assim, de acordo com as palavras do Professor Marco Aurélio Marrafon,

(...) a análise estrutural do enunciado feita pelo logos apofântico é necessária, ou seja, o texto constitucional vincula (inclusive de maneira mais rígida em matéria penal, tributária, direitos fundamentais e garantias processuais fundamentais, em razão da própria origem protetiva de direitos). Contudo, o sentido normativo e seu resultado "norma" estão além do texto, porque a análise de sua estrutura é sempre insuficiente, vez que só atinge o ente e não alcança o "sentido da estrutura", fornecido pelo logos hermenêutico, por meio da leitura hermenêutica e os significados pré-existentes no mundo prático.

De qualquer modo, não resta dúvida de que a observância do texto, sem peripécias interpretativas, é fundamental para preservar a lei e salvá-la do império das vontades, pois o Judiciário (e, em especial, seu órgão de cúpula) não pode desempenhar o papel de novo soberano. ${ }^{34}$

Os critérios distintivos entre princípios e regras compõem objeto de amplo debate doutrinário em níveis nacional e internacional.

\footnotetext{
${ }^{31}$ MARRAFON, Marco Aurélio. Texto constitucional não é norma, mas vincula. Disponível em: $<$ http://www.conjur.com.br/2015-dez-28/constituicao-poder-texto-constitucional-nao-norma-vincula >. Acesso em 3 jan. 2016.

${ }^{32}$ STRECK, Lenio. Jurisdição constitucional e hermenêutica: uma nova crítica do direito. 2 ed. Rio de Janeiro: Forense, 2004. p. 246 apud MARRAFON, Marco Aurélio. Texto constitucional não é norma, mas vincula. Disponível em: <http://www.conjur.com.br/2015-dez-28/constituicao-poder-texto-constitucional-nao-normavincula >. Acesso em 3 jan. 2016.

${ }^{33}$ MARRAFON, Marco Aurélio. Texto constitucional não é norma, mas vincula. Disponível em: <http://www.conjur.com.br/2015-dez-28/constituicao-poder-texto-constitucional-nao-norma-vincula >. Acesso em 3 jan. 2016.

${ }^{34}$ MARRAFON, Marco Aurélio. Texto constitucional não é norma, mas vincula. Disponível em: <http://www.conjur.com.br/2015-dez-28/constituicao-poder-texto-constitucional-nao-norma-vincula >. Acesso em 3 jan. 2016.
} 
Descrevamos, genericamente, os modelos clássicos de distinção entre princípios e regras. Para as chamadas "distinções quantitativas" ou "distinções fracas”, princípios e regras possuem características comuns, mas com gradações distintas.

Nesse sentido, são considerados critérios quantitativos: o critério da indeterminação, segundo o qual os princípios são mais vagos e mais ambíguos que as regras; o critério da generalidade - critério mais utilizado para a distinção entre regras e princípios -, para o qual os princípios são normas com maior grau de generalidade, enquanto as regras possuem generalidade relativamente baixa ${ }^{35}{ }_{-3}^{36}$; o critério do papel do intérprete, segundo o qual o intérprete possui participação criativa e mais ativa ao aplicar princípios, o que não ocorre na aplicação de regras, uma vez que estas não admitem valorações subjetivas; o critério da importância na ordem jurídica ${ }^{37}$; o critério do papel desempenhado pelos princípios na ordem jurídica $^{38}$; o critério do conteúdo moral, para o qual os princípios possuem uma dimensão moral maior do que a das regras, incorporando e normatizando valores fundamentais, traduzindo-os em termos normativos ${ }^{39}$. Entretanto, no que tange a este último critério, Daniel Sarmento e Cláudio Pereira asseveram que existem regras dotadas de forte conteúdo moral, como é o caso da proibição da pena de morte (art. 5, XLVII, CF). Assim, para os autores, mais adequado é afirmar que os princípios, por sua "maior abertura linguística, franqueiam mais espaço para considerações morais na argumentação jurídica”, enquanto as regras, por

\footnotetext{
${ }^{35}$ ALEXY, Robert. Teoria dos Direitos Fundamentais (2a ed.). Tradução de Virgílio Afonso da Silva da $5^{\mathrm{a}}$ edição alemã Theorie der Grundrechte. São Paulo: Malheiros Editores, 2009, p. 89.

${ }^{36}$ Eros Roberto Grau refere-se à maior generalidade dos princípios porque estes, ao contrário das regras, não incidem apenas sobre determinado tipo de atos ou fatos definidos na sua hipótese de incidência, comportando antes "uma série indefinida de aplicações". Vide: GRAU, Eros Roberto. A ordem econômica na Constituição de 1988: interpretação e crítica. 2.ed. São Paulo: Revista dos Tribunais, 1991, p. 112.

${ }^{37}$ Para esse critério, os princípios, individualmente considerados, são mais importantes na ordem jurídica do que as regras, ou seja, normas principiológicas possuem, individualmente, maior relevância sistêmica em comparação àquelas que concernem às regras. Registre-se que esse critério foi utilizado pelo Professor Celso Antônio Bandeira de Mello, ao conceituar o princípio jurídico como "mandamento nuclear de um sistema, verdadeiro alicerce dele, disposição fundamental que se irradia sobre diferentes normas, compondo-lhes o espírito e servindo de critério para sua exata compreensão e inteligência, exatamente por definir a lógica e a racionalidade do sistema normativo, no que lhe confere a tônica e lhe dá sentido harmônico". Vide: BANDEIRA DE MELLO, Celso Antonio. Elementos de direito administrativo. São Paulo: Revista dos Tribunais, 1986, p. 230.

${ }^{38}$ Para o critério da função ou papel desempenhado na ordem jurídica, os princípios desempenham função argumentativa mais importante do que as regras, uma vez que servem de guia para a aplicação e interpretação das demais normas. Fala-se, aqui, na produção de efeitos irradiantes dos princípios, que se projetam mais amplamente pelo ordenamento. Vide: CANARIS, Claus Wilhelm. Pensamento sistemático e conceito de sistema na ciência do direito. Tradução de A, Menezes Cordeiro. Lisboa: Fundação Calouste Gulbenkian, 1989, p. 76102.

${ }^{39}$ LARENZ, Karl. Derecho justo: fundamentos de ética jurídica, p. 32-42 apud SOUZA NETO, Cláudio Pereira de; SARMENTO, Daniel. Direito Constitucional: Teoria, história e métodos de trabalho. 2. ed. Belo Horizonte: Fórum, 2014, p. 382.
} 
sua "maior densidade semântica, não conferem tamanha liberdade para que o intérprete persiga a solução mais justa para o problema enfrentado". 40

Há, ainda outros critérios de diferenciação, tais como "a determinabilidade dos casos de aplicação", o caráter explícito de seu conteúdo axiológico, a referência à ideia de direito ou a uma lei jurídica suprema, o fato de serem razões para regras ou serem eles mesmos regras, o fato de serem normas de argumentação ou normas de comportamento. ${ }^{41}$

Já as distinções de natureza qualitativa ou "distinções fortes" mencionam a existência de categorias absolutamente separadas e estanques de normas jurídicas, com características próprias e inconfundíveis. Ressalte-se que são essas as distinções mais utilizadas pelo ordenamento jurídico brasileiro, atualmente. É nesse cenário que encontramos as distinções trazidas por Ronald Dworkin e por Robert Alexy.

\subsubsection{Ronald Dworkin - The Model of Rules (all or nothing) e o ordenamento principiológico}

No artigo The Model of Rules, publicado no livro Taking Rights Seriously, Ronald Dworkin contraria-se com a insuficiência das crenças e posturas positivistas. A versão positivista-jurídica de H.L.A. Hart ${ }^{42}$ defende a existência da discricionariedade judicial para a solução dos casos difíceis do direito, os chamados hard cases, diante da "textura aberta" das normas jurídicas. Essa versão, para Dworkin, teria ignorado o papel dos princípios, pois a ausência de uma norma clara e precisa que indique a solução para determinado caso não confere ao juiz o poder discricionário para decidi-lo, sendo ele obrigado a recorrer aos princípios, que, uma vez interpretados adequadamente, conduzirão o intérprete à tomada da solução mais correta para o caso. ${ }^{43}$

Para Dworkin, princípios e regras apresentam uma distinção de natureza qualitativa pertencente ao seu modo de aplicação. Para ele, as regras determinam consequências precisas, e consistem em comandos disjuntivos, aplicados nos conformes do padrão tudo ou nada (all or nothing). Isso significa que, se a hipótese de incidência de uma regra é preenchida, ou a

\footnotetext{
${ }^{40}$ SOUZA NETO, Cláudio Pereira de; SARMENTO, Daniel. Direito Constitucional: Teoria, história e métodos de trabalho. 2. ed. Belo Horizonte: Fórum, 2014, p. 383.

${ }^{41}$ ALEXY, Robert. Teoria dos Direitos Fundamentais (2a ed.). Tradução de Virgílio Afonso da Silva da $5^{\mathrm{a}}$ edição alemã Theorie der Grundrechte. São Paulo: Malheiros Editores, 2009, p. 89.

${ }^{42}$ Cf. HART, H.L.A (1961). The Concept of Law. Oxford University Press: Oxford, 2012.

${ }^{43}$ DWORKIN, Ronald. Taking Rights Seriously. Cambridge: Harvard University Press, 1977, p. 131-149;

DWORKIN, Ronald. A Matter of Principle. Cambridge: Harvard University Press, 1985, p. 119-180;

DWORKIN, Ronald. Law's Empire. Cambridge: Harvard University Press, 1986, p. 225-275; DWORKIN,

Ronald. Justice for Hedgehogs. Cambridge: The Belknap Press, 2011, p. 400-415.
} 
regra será válida, devendo ser aplicada, produzindo-se as consequências jurídicas respectivas - tudo -; ou a regra será inválida, ou inaplicável ao caso - nada. ${ }^{44}$

Portanto, no caso de colisão entre regras, o intérprete socorrer-se-á de critérios formais para identificar qual das regras deverá ser considerada inválida ou inaplicável: de acordo com o critério hierárquico, a regra hierarquicamente superior prevalece sobre a regra hierarquicamente inferior; se se tratar de regras de mesma hierarquia, o critério cronológico será usado, sendo que prevalecerá a regra posterior; e, por fim, o critério da especialidade elucida que prevalecerá a regra especial que se chocar com uma regra geral. ${ }^{45}$

Inerentes a uma lógica completamente distinta, os princípios, para Dworkin, possuem o que ele denominou de dimensão de peso. Assim, nos casos de colisão entre princípios que apontem para soluções diferentes, será necessário analisar qual a importância assumida por cada um no caso em questão, para definir aquele que deverá prevalecer.

Em trabalhos mais recentes, Ronald Dworkin direciona suas forças para uma aplicação coerente dos princípios, baseada no ideal da integridade, como suficiente para excluir todos os conflitos em questão. ${ }^{46}$

Portanto, diante da colisão entre princípios, far-se-á uma análise substantiva, não se aplicando a lógica do tudo ou nada que, somente se aplica frente a regras colidentes. Além disso, o intérprete realizará uma apuração da importância de cada princípio no caso concreto para então chegar à decisão de qual deles prevalecerá. A solução passa, destarte, por uma análise argumentativa.

Indo mais além, Dworkin propõe que até mesmo as regras devem ser lidas sob um viés principiológico. Ele admite a complexidade do modelo de um ordenamento de princípios, que se apresenta por inteiro e, a um só tempo, onde, ao se tratar de princípios colidentes - apesar de serem princípios opostos -, merecem a leitura de que essa tensão é produtiva e reciprocamente constitutiva. Desse modo, os "princípios opostos" e igualmente válidos “dependem do caso concreto para que seja possível discernir a pretensão abusiva da correta que, com base nele, são levantadas". 47

Por isso mesmo, o caso em sua concretude e irrepetibilidade deve ser reconstruído de todas as perspectivas possíveis, consoante as próprias pretensões a direito

\footnotetext{
${ }^{44}$ DWORKIN, Ronald. Taking Rights Seriously. Cambridge: Harvard University Press, 1977, p. 131-149.

${ }^{45}$ DWORKIN, Ronald. Taking Rights Seriously. Cambridge: Harvard University Press, 1977, p. 131-149.

${ }^{46}$ DWORKIN, Ronald. Do liberty and equality conflict? In: BARKER, Paul. Living as equals, p.39-58; DWORKIN, Ronald. Moral Pluralism. In: DWORKIN, Ronald. Justice in Robes, p. 105-116.

${ }^{47}$ CARVALHO NETTO, Menelick de; SCOTTI, Guilherme. Os Direitos Fundamentais e a (in)certeza do Direito: a produtividade das tensões principiológicas e a superação do sistema de regras. Belo Horizonte: Editora Fórum, 2011, p. 9.
} 
levantadas, no sentido de se alcançar a norma adequada, a única capaz de produzir justiça naquele caso específico. ${ }^{48}$

Estamos diante da questão interpretativa sugerida por Dworkin, com a sua tese da única decisão correta, que será posteriormente aprofundada neste estudo. Para ele, cada caso é marcado pela unicidade e pela irrepetibilidade.

Assim, a partir da compreensão dworkineana, percebemos que o princípio pressupõe que se considere o oposto a ele, e, portanto, trata-se de opostos que se complementam. Há que se extrair a produtividade dessa tensão para que se consiga caminhar rumo a melhor decisão diante de um caso constitucional.

Para Dworkin, os princípios dividem-se em duas espécies: princípios em sentido estrito e diretrizes políticas - policies. Seguindo essa lógica, os princípios em sentido estrito relacionam-se aos direitos, devendo ser observados não porque essa observância promoverá ou garantirá alguma situação econômica, política ou social considerada desejável, mas porque se trata de uma exigência de justiça, de equidade ou de alguma outra dimensão da moralidade. Por outro lado, as policies consistem em standards que estabelecem "um objetivo a ser alcançado, geralmente a melhoria de algum aspecto econômico, político ou social da comunidade". 49

Daniel Sarmento e Cláudio Pereira reconhecem que a compreensão dworkineana é fiel ao ideário liberal, e atribui "primazia absoluta aos princípios em sentido estrito em relação às diretrizes políticas", de forma que, havendo conflito, os primeiros devem prevalecer. ${ }^{50} \mathrm{Tal}$ colocação adéqua-se quando compreendemos a estrutura principiológica do ordenamento jurídico proposta por Dworkin, que nos possibilita entender os princípios jurídicos em sua integridade, bem como a primazia dos argumentos de princípio, que remetem a uma análise do conteúdo dos direitos fundamentais, e de sua respectiva compreensão da validade deontológica desses direitos.

Destarte, a leitura positivista do direito enquanto sistema autossuficiente de regras que almeja regular com alto grau de determinação as situações de aplicação - deixa escassa a dimensão central de qualquer ordenamento jurídico pós-convencional:

\footnotetext{
${ }^{48}$ CARVALHO NETTO, Menelick de; SCOTTI, Guilherme. Os Direitos Fundamentais e a (in)certeza do Direito: a produtividade das tensões principiológicas e a superação do sistema de regras. Belo Horizonte: Editora Fórum, 2011, p. 9.

${ }^{49}$ DWORKIN, Ronald. Taking Rights Seriously. Cambridge: Harvard University Press, 1977, p. 22 apud SOUZA NETO, Cláudio Pereira de; SARMENTO, Daniel. Direito Constitucional: Teoria, história e métodos de trabalho. 2. ed. Belo Horizonte: Fórum, 2014, p. 384.

${ }^{50}$ SOUZA NETO, Cláudio Pereira de; SARMENTO, Daniel. Direito Constitucional: Teoria, história e métodos de trabalho. 2. ed. Belo Horizonte: Fórum, 2014, p. 384.
} 
(...) sua estrutura principiológica, necessariamente indeterminada em abstrato, embora determinável em concreto, aberta hermeneuticamente à construção intersubjetiva dos sentidos das normas universalistas positivadas enquanto direitos fundamentais ${ }^{51}$.

Nesse ínterim, em um sistema principiológico, até mesmo as regras, por mais que especifiquem com riqueza de detalhes as suas hipóteses de aplicação, não são capazes de esgotá-las. Por isso, podem ter sua aplicação afastada diante de princípios, "sempre com base na análise e no cotejo das reconstruções fáticas e das pretensões a direito levantadas pelas partes na reconstrução das especificidades próprias daquele determinado caso concreto". 52

A partir da compreensão do caráter normativo dos princípios jurídicos, verificamos que, não obstante sejam gerais e abstratos, mas, acima disso, eles exigem do intérprete uma “densificação voltada à história institucional e à sistematicidade do conjunto de princípios reciprocamente vinculados do Direito" ${ }^{, 53}$, sendo possível afastar a perspectiva decisionista a que chega o positivismo.

\subsubsection{Robert Alexy - princípios como mandamentos de otimização}

Elaborando também uma distinção qualitativa entre princípios e regras, o jurista alemão também ganhou notoriedade em relação ao tema. Não obstante essa distinção tenha alguns pontos de contato com a distinção formulada por Dworkin, ela possui compreensões diferentes.

A principal diferenciação teorético-estrutural para a teoria dos direitos fundamentais de Robert Alexy é a distinção entre regras e princípios, que, segundo o professor, constitui a "base da teoria da fundamentação no âmbito dos direitos fundamentais e uma chave para a solução de problemas centrais da dogmática dos direitos fundamentais". 54

Essa distinção, sob tal ótica, constitui um elemento indispensável da dogmática dos direitos de liberdade e de igualdade, por exemplo. Ela é a intenção alexiana de configurar o ponto de partida para a resposta dos questionamentos acerca da possibilidade e dos limites da

\footnotetext{
${ }^{51}$ CARVALHO NETTO, Menelick de; SCOTTI, Guilherme. Os Direitos Fundamentais e a (in)certeza do Direito: a produtividade das tensões principiológicas e a superação do sistema de regras. Belo Horizonte: Editora Fórum, 2011, p. 23-24.

${ }^{52}$ CARVALHO NETTO, Menelick de; SCOTTI, Guilherme. Os Direitos Fundamentais e a (in)certeza do Direito: a produtividade das tensões principiológicas e a superação do sistema de regras. Belo Horizonte: Editora Fórum, 2011, p. 23-24.

${ }^{53}$ CARVALHO NETTO, Menelick de; SCOTTI, Guilherme. Os Direitos Fundamentais e a (in)certeza do Direito: a produtividade das tensões principiológicas e a superação do sistema de regras. Belo Horizonte: Editora Fórum, 2011, p. 23-24.

${ }^{54}$ ALEXY, Robert. Teoria dos Direitos Fundamentais (2. ed.). Tradução de Virgílio Afonso da Silva da $5^{\mathrm{a}}$ edição alemã Theorie der Grundrechte. São Paulo: Malheiros Editores, 2009, p. 85.
} 
racionalidade no campo dos direitos fundamentais. Nesse sentido, para Alexy, a distinção entre regras e princípios assume a posição de uma das "colunas-mestras do edifício da teoria dos direitos fundamentais". 55

O critério adotado por Alexy posiciona os princípios como verdadeiros mandamentos de otimização, é dizer, "são normas que ordenam que algo seja realizado na maior medida possível dentro das possibilidades jurídicas e fáticas existentes" ${ }^{~} 56$. Esses mandamentos podem ser satisfeitos em graus variados, e a medida devida de sua satisfação depende das possibilidades jurídicas $^{57}$, e não apenas das possibilidades fáticas.

As regras, por sua vez, "são normas que são sempre ou satisfeitas ou não satisfeitas". Diante de uma regra válida, portanto, deve-se fazer exatamente o que ela exige - nem mais, nem menos. Assim, as regras contêm "determinações no âmbito daquilo que é fática e juridicamente possível" ${ }^{, 58}$. Portanto, Alexy enxerga as regras como comandos definitivos, que, quando válidos e incidem em uma situação concreta, devem ser integralmente aplicados.

E mais, Alexy não admite o cumprimento gradual de regras: ou as regras são cumpridas integralmente, ou são descumpridas. Na há, portanto, ponderação de regras segundo a compreensão alexiana.

Destarte, verifica-se que é qualitativa, e não de grau, a distinção entre regras e princípios abordada por Alexy.

Alexy assevera que um conflito entre regras encontra duas soluções: a introdução de uma cláusula de exceção que elimine o conflito, ou que uma das regras seja declarada inválida, uma vez que não é possível que dois juízos concretos de dever-ser contraditórios entre si sejam válidos. ${ }^{59}$ Assim, os conflitos entre regras se dão na dimensão da validade. Por outro lado, muito diferente é a solução a ser dada quando se está frente a uma colisão entre princípios - quando, por exemplo, algo é proibido de acordo com um princípio e, permitido, de acordo com outro -, um deles terá de ceder, o que não significa que o princípio cedente deva ser invalidado, tampouco que nele deva ser introduzida uma cláusula de exceção.

\footnotetext{
${ }^{55}$ ALEXY, Robert. Teoria dos Direitos Fundamentais (2 ${ }^{\mathrm{a}}$ ed.). Tradução de Virgílio Afonso da Silva da $5^{\mathrm{a}}$ edição alemã Theorie der Grundrechte. São Paulo: Malheiros Editores, 2009, p. 85.

${ }^{56}$ ALEXY, Robert. Teoria dos Direitos Fundamentais (2a ed.). Tradução de Virgílio Afonso da Silva da $5^{\mathrm{a}}$ edição alemã Theorie der Grundrechte. São Paulo: Malheiros Editores, 2009, p.90.

${ }_{57}$ Nesse sentido, o âmbito das possibilidades jurídicas será determinado pelos princípios e regras colidentes.

${ }^{58}$ ALEXY, Robert. Teoria dos Direitos Fundamentais (2 ${ }^{\mathrm{a}}$ ed.). Tradução de Virgílio Afonso da Silva da $5^{\mathrm{a}}$ edição alemã Theorie der Grundrechte. São Paulo: Malheiros Editores, 2009, p. 91.

${ }^{59}$ ALEXY, Robert. Teoria dos Direitos Fundamentais (2 ${ }^{\mathrm{a}}$ ed.). Tradução de Virgílio Afonso da Silva da $5^{\mathrm{a}}$ edição alemã Theorie der Grundrechte. São Paulo: Malheiros Editores, 2009, p. 92-93.
} 
Na colisão entre princípios, o que ocorre é que um dos princípios conflitantes terá precedência $^{60}$ em face do outro, sob determinadas condições. Uma vez que o conflito ocorre entre princípios válidos, essa colisão incide na dimensão do peso: nos casos concretos, os princípios possuem pesos distintos, e os princípios com maior peso terão precedência. ${ }^{61}$ Aqui não se está falando da existência de uma precedência absoluta. O conflito deve ser solucionado mediante um sopesamento entre os interesses conflitantes. Abstratamente falando, os interesses conflitantes têm o mesmo nível; mas, no caso concreto, um terá maior peso sobre o outro.

Alexy assevera que, os princípios, se isoladamente considerados, podem conduzir a uma contradição, o que significa que, no caso de princípios em rota de tensão, um deles restringe as possibilidades jurídicas de realização do outro. Portanto, Alexy estabelece que a solução para esses casos é a construção de uma relação de precedência condicionada entre os princípios, sempre com base nas circunstâncias do caso concreto. ${ }^{62}$

Ao contrário de Dworkin, Alexy não enxerga a tensão entre princípios como constitutiva e produtiva, devendo ser resolvida mediante o uso de um método que analisa os princípios gradualmente.

O estabelecimento das relações de precedência condicionada significa "a fixação de condições sob as quais um princípio tem precedência em face do outro". ${ }^{63}$ Assim, sob uma determinada condição $C$, um princípio $P_{l}$ terá precedência $\boldsymbol{P}$ sobre o outro princípio $P_{2}:\left(P_{l} \boldsymbol{P}\right.$ $\left.P_{2}\right) C$. Sob a luz de outra condição, o princípio $P_{2}$ terá prevalência sobre o princípio $P_{1}:\left(P_{2} \boldsymbol{P}\right.$ $\left.P_{l}\right) C$. Todavia, pergunta-se: sob quais condições qual princípio deve prevalecer e qual deve ceder?

À luz do Tribunal Constitucional Federal Alemão, Alexy aprecia a difundida metáfora do peso. De acordo com a teoria das relações de precedências, ressaltam-se as condições sob as quais se verifica uma violação a um direito fundamental. "Se uma ação viola um direito fundamental, isso significa que, do ponto de vista dos direitos fundamentais, ela é proibida". Assim, pode-se afirmar que a condição de precedência, identificada pela letra “ $C$ ”, realiza um duplo papel: ao mesmo tempo em que é condição de uma relação de precedência, é utilizada

\footnotetext{
${ }^{60}$ ALEXY, Robert. Teoria dos Direitos Fundamentais (2a ed.). Tradução de Virgílio Afonso da Silva da $5^{\mathrm{a}}$ edição alemã Theorie der Grundrechte. São Paulo: Malheiros Editores, 2009, p. 95-96.

${ }^{61}$ ALEXY, Robert. Teoria dos Direitos Fundamentais (2a ed.). Tradução de Virgílio Afonso da Silva da $5^{\mathrm{a}}$ edição alemã Theorie der Grundrechte. São Paulo: Malheiros Editores, 2009, p. 93-94.

62 ALEXY, Robert. Teoria dos Direitos Fundamentais (2a ed.). Tradução de Virgílio Afonso da Silva da $5^{\mathrm{a}}$ edição alemã Theorie der Grundrechte. São Paulo: Malheiros Editores, 2009, p. 93-96.

${ }^{63}$ ALEXY, Robert. Teoria dos Direitos Fundamentais (2 ${ }^{\mathrm{a}}$ ed.). Tradução de Virgílio Afonso da Silva da $5^{\mathrm{a}}$ edição alemã Theorie der Grundrechte. São Paulo: Malheiros Editores, 2009, p. 93-96.
} 
para indicar se uma determinada ação é proibida sob o ponto de vista dos direitos fundamentais. ${ }^{64}$

Destarte, $C$ é o pressuposto do suporte fático de uma regra. Alexy defende uma formulação onde "as condições sob as quais um princípio tem precedência em face de outro constituem o suporte fático de uma regra que expressa a consequência jurídica do princípio que tem precedência". ${ }^{65}$ A essa lei denomina-se "lei de colisão", sendo ela um dos fundamentos da teoria dos princípios defendida por Alexy.

A lei de colisão é um reflexo do atributo de mandamentos de otimização inerente aos princípios - a inexistência de precedência absoluta e sua dimensão não quantitativa. Nesse sentido, explica Alexy:

[...] A lei de colisão conduz a uma dogmática diferenciada dos direitos fundamentais específicos, isto é, não a preferências e cedências generalizantes. Assim, nos termos dessa lei, o estabelecimento de uma restrição não é uma questão tudo-ou-nada, mas um problema de "afastamento do direito fundamental em relações individuais". ${ }^{6}$

Entre os variados objetos do sopesamento indicados por Alexy, acrescentem-se os "valores constitucionais". ${ }^{67}$

Assim, para Alexy, os princípios clamam que algo seja realizado na maior medida possível dentro das possibilidades jurídicas e fáticas existentes, não contendo, portanto, um mandamento definitivo, mas prima facie. Nesse ínterim, poderão as razões dos princípios ser afastadas por razões antagônicas. A forma como é determinada a relação razão e contrarrazão não é definida pelo próprio princípio. Destarte, “os princípios não dispõem da extensão de seu conteúdo em face dos princípios colidentes e das possibilidades fáticas". ${ }^{6}$

Diante de colisão, Alexy propõe que se recorra à ponderação entre os princípios, pautada nos critérios da proporcionalidade, o que não acontece para as regras. ${ }^{69}$

Ao analisar a necessidade de um modelo diferenciado a respeito das regras e dos princípios, Alexy critica o modelo compreendido por Ronald Dworkin, onde, conforme a crítica alexiana, os princípios têm sempre um mesmo caráter prima facie, enquanto as regras,

\footnotetext{
${ }^{64}$ ALEXY, Robert. Teoria dos Direitos Fundamentais (2a ed.). Tradução de Virgílio Afonso da Silva da $5^{\mathrm{a}}$ edição alemã Theorie der Grundrechte. São Paulo: Malheiros Editores, 2009, p. 98.

${ }^{65}$ ALEXY, Robert. Teoria dos Direitos Fundamentais (2a ed.). Tradução de Virgílio Afonso da Silva da $5^{\mathrm{a}}$ edição alemã Theorie der Grundrechte. São Paulo: Malheiros Editores, 2009, p. 99.

${ }^{66}$ ALEXY, Robert. Teoria dos Direitos Fundamentais (2 ${ }^{\mathrm{a}}$ ed.). Tradução de Virgílio Afonso da Silva da $5^{\mathrm{a}}$ edição alemã Theorie der Grundrechte. São Paulo: Malheiros Editores, 2009, p. 99. Cf. BVerfGE 28, 243 (263).

${ }^{67}$ ALEXY, Robert. Teoria dos Direitos Fundamentais (2 ${ }^{\mathrm{a}}$ ed.). Tradução de Virgílio Afonso da Silva da $5^{\mathrm{a}}$ edição alemã Theorie der Grundrechte. São Paulo: Malheiros Editores, 2009, p. 101.

${ }^{68}$ ALEXY, Robert. Teoria dos Direitos Fundamentais ( $2^{\mathrm{a}}$ ed.). Tradução de Virgílio Afonso da Silva da $5^{\mathrm{a}}$ edição alemã Theorie der Grundrechte. São Paulo: Malheiros Editores, 2009, p. 104.

${ }^{69}$ ALEXY, Robert. Teoria dos Direitos Fundamentais (2a ed.). Tradução de Virgílio Afonso da Silva da $5^{\mathrm{a}}$ edição alemã Theorie der Grundrechte. São Paulo: Malheiros Editores, 2009, p. 93-120.
} 
um mesmo caráter definitivo. Para Alexy, Dworkin entende que as regras, caso sejam válidas, devem ser aplicadas de forma tudo-ou-nada, enquanto que os princípios contêm razões capazes de indicar uma direção, não tendo como consequência necessária uma determinada decisão. $^{70}$

Para Alexy, a equação das tensões entre princípios constitucionais solicita que se recorra à ponderação, que busca a otimização dos bens jurídicos em jogo.

\subsubsection{Contribuições da literatura jurídica brasileira}

No direito constitucional pátrio, a contribuição mais genuína ao debate sobre princípios e regras é de Humberto Ávila. Ao estudar a teoria dos princípios, o autor três critérios para a diferenciação entre regras e princípios, a saber: natureza do comportamento prescrito, natureza da justificação exigida de quem aplica a norma, e a medida da sua contribuição para a decisão.

Com relação ao primeiro critério, uma vez que estabelecem um estado ideal de coisas a ser atingido, os princípios são imediatamente finalísticos, ao passo que as regras são imediatamente prescritivas, já que elas preveem condutas a serem observadas. ${ }^{71}$ Explica o autor que, apesar de, em verdade, ambas as espécies normativas ligarem-se tanto a fins como a condutas, a distinção se mantém. No que tange aos princípios, a relação com os fins é direta e com as condutas, indireta; enquanto para regras, ocorre exatamente o inverso. ${ }^{72}$

Para o critério da natureza da justificação exigida, Ávila propõe que, ao operar com as regras, o intérprete tem o papel de, basicamente, verificar se os fatos se enquadram na descrição contida na norma. O autor admite ainda que, "em casos excepcionais, e com pesado ônus argumentativo, ele poderá analisar se os fatos, embora correspondentes à previsão normativa, contrariam os fins que dão suporte à regra”, fato que justificaria a sua não incidência, ou se a aplicação da regra pode ser superada por outras razões contrapostas (caso de superabilidade da regra). ${ }^{73}$ Já no caso dos princípios, caberá ao intérprete analisar se os efeitos da conduta correlacionam-se positivamente, ou não com o estado ideal de coisas almejado, contribuindo para a sua promoção.

\footnotetext{
${ }^{70}$ ALEXY, Robert. Teoria dos Direitos Fundamentais (2 $2^{\mathrm{a}}$ ed.). Tradução de Virgílio Afonso da Silva da $5^{\mathrm{a}}$ edição alemã Theorie der Grundrechte. São Paulo: Malheiros Editores, 2009, p. 104, Cf. Ronald Dworkin, Taking Rights Seriously, pp. 24 e 26.

71 ÁVILA, Humberto. Teoria dos princípios. 11.ed. São Paulo: Malheiros, 2010, p. 71.

72 ÁVILA, Humberto. Teoria dos princípios. 11.ed. São Paulo: Malheiros, 2010, p. 73.

${ }^{73}$ ÁVILA, Humberto. Teoria dos princípios. 11.ed. São Paulo: Malheiros, 2010, p. 73-76.
} 
Finalmente, Ávila sustenta que as regras possuem a pretensão de definir, de modo exclusivo, as soluções para as hipóteses de incidência, com o afastamento das demais razões e considerações. Tal característica é apregoada como "pretensão de decidibilidade e abrangência das regras". Por outro lado, traçando rota distinta, os princípios buscam contribuir para a adoção da solução adequada ao caso, possuindo a "pretensão de complementaridade e parcialidade". ${ }^{74}$

É digna de menção a propositura de um "outro modelo de diferença entre princípios e regras constitucionais", do Professor Marcelo Neves, segundo a qual mais além da disposição constitucional, a partir da inferência lógica de princípios do texto constitucional como um todo pelo intérprete-aplicador, atenta para o fato de que este processo não pode ser arbitrário. Assim, os princípios "construídos" no processo de concretização do texto constitucional e respectiva enunciação de normas "devem ser, no mínimo, compatíveis com a conexão de disposições constitucionais". ${ }^{75}$

Para Marcelo Neves, os critérios de distinção entre regras e princípios pautados de modo quantitativo ou qualitativo têm sido colocados inadequadamente. Segundo o autor, a diferença entre princípios e regras deve ser construída a partir de dois conceitos de conteúdo, não propriamente como uma "forma-de-dois-lados", mas como "conceitos típico-ideal nos termos da tradição weberiana".

Tais "tipos ideais" são utilizados como formas de interpretação da realidade social conferindo-se "ênfase unilateral em determinados elementos mais relevantes do conhecimento que se pretende obter". No plano normativo, eles contribuem, especialmente, como meio de “ordenação seletiva de disposições e enunciados normativos", à luz da lei e demais fontes do direito, da jurisprudência, doutrina, etc. assim, mesmo que, por exemplo, a "textualização constitucional" nos possa ajudar a perceber que tipo de norma está em pauta, ainda não é possível definir, de antemão, qual padrão consiste num princípio ou numa regra, o que irá “depender do modo mediante o qual a norma será incorporada do ponto de vista funcionalestrutural no processo argumentativo". 76

Acrescente-se, ainda, que, sendo "tipos ideais como categorias gnosiológicas", tais conceitos normativos não se quedam imunes à "contaminação recíproca” entre si. É por esse motivo que se fala em sua hibridez, visto que são "normas que se encontram em uma situação

\footnotetext{
74 ÁVILA, Humberto. Teoria dos princípios. 11.ed. São Paulo: Malheiros, 2010, p. 77.

${ }^{75}$ NEVES, MARCELO. Entre Hidra e Hércules: princípios e regras constitucionais como diferença paradoxal do sistema jurídico. São Paulo: Editora WMF Martins Fontes, 2013, p. 89 e ss.

${ }^{76}$ NEVES, MARCELO. Entre Hidra e Hércules: princípios e regras constitucionais como diferença paradoxal do sistema jurídico. São Paulo: Editora WMF Martins Fontes, 2013, p. 89 e ss.
} 
intermediária entre princípios e regras". Marcelo neves apregoa que os chamados "postulados normativos aplicativos" podem consistir em princípios, em regras ou no grupo dos "híbridos", consoante sejam ou não "regras imediatamente finalísticas":

(i) se não forem razões definitivas para uma norma de decisão de questões jurídicas, devem ser tratadas como princípios; (ii) se forem normas susceptíveis de actuar como razão definitiva de questões jurídicas, trata-se de regras; (iii) se não for possível enquadrá-las em nenhuma destas categorias, são os híbridos. ${ }^{77}$

O autor destaca o princípio da proporcionalidade como "uma condição de possibilidade do funcionamento efetivo e consistente de uma ordem de regras e princípios, assim como, especialmente, de um ordenamento de direito fundamentais". Ademais, tal princípio apresenta uma dupla face: por um lado, trata-se de "condição de possibilidade de funcionamento da própria Constituição"; ao passo que, por outro lado, afigura-se como uma verdadeira norma, na medida em que é também concebido como um "dever dos encarregados da interpretação-aplicação normativa”. É quando Neves aponta a obediência ao critério da proporcionalidade como reentry, ou seja, "o que é condição de possibilidade da ordem passa a ser norma da própria ordem". 78

Sob tal perspectiva, pergunta-se se a proporcionalidade seria um princípio ou uma regra. Neves considera que os critérios da adequação e da necessidade podem ser vistos como regras, tendo em vista que se apresentam como razões definitivas para que se decida se a medida de restrição a direitos fundamentais é adequada e necessária ao fim que dispõe a realizar. Por sua vez, a proporcionalidade em sentido estrito inclui o mandamento da ponderação, sendo, por isso, considerada "híbrida": estruturalmente é uma regra - "um critério ou uma razão definitiva para a solução do caso"; e funcionalmente é um princípio "atua no nível reflexivo do sistema jurídico, articulado com os princípios que pretende sopesar". ${ }^{79}$

Portanto, a partir da compreensão de que vivenciamos um contexto social hipercomplexo, Marcelo Neves aponta não ser a Constituição composta apenas por regras, mas também por princípios. Ademais, sob a ótica da dinâmica jurídica, tal como a relação entre Constituição e lei importa numa relação circular e não numa hierarquia linear, "a

\footnotetext{
${ }^{77}$ NEVES, MARCELO. Entre Hidra e Hércules: princípios e regras constitucionais como diferença paradoxal do sistema jurídico. São Paulo: Editora WMF Martins Fontes, 2013, p. 89 e ss.

${ }^{78}$ NEVES, MARCELO. Entre Hidra e Hércules: princípios e regras constitucionais como diferença paradoxal do sistema jurídico. São Paulo: Editora WMF Martins Fontes, 2013, p. 89 e ss.

${ }^{79}$ NEVES, MARCELO. Entre Hidra e Hércules: princípios e regras constitucionais como diferença paradoxal do sistema jurídico. São Paulo: Editora WMF Martins Fontes, 2013, p. 89 e ss.
} 
diferença entre princípios e regras constitucionais, do ponto de vista da estática jurídica, envolve uma relação de pressuposição recíproca". ${ }^{80}$

Por fim, ao discorrer sobre a aplicação de princípios colidentes, o autor compreende a exigência da ponderação como inafastável, sendo ela "uma das técnicas constitucionais de absorção do dissenso e, simultaneamente, de sua viabilização e promoção". ${ }^{81}$ Não resta dúvidas de que "a Constituição do Estado democrático de direito envolve uma articulação complexa e dinâmica entre princípios e regras" e que a "ponderação de princípios colidentes é uma das técnicas de argumentação e interpretação constitucional, permitindo a comparação de diferentes perspectivas da Constituição e dos direitos fundamentais". 82 O autor descarta o modelo de ponderação otimizante de princípios, devido a concorrência e incomensurabilidade dos modos de argumentação em torno de princípios, relacionadas tanto à dupla contingência de grupos e de pessoas envolvidas no processo de concretização constitucional quanto à heterogeneidade de perspectivas de princípios desenvolvidas pelos sistemas funcionais diferenciados, o que se torna ainda mais complexo "quando se consideram as perspectivas de outras ordens jurídicas envolvidas simultaneamente na solução de problemas constitucionais comuns". 83

Não obstante os inúmeros critérios existentes para a diferenciação entre princípios e regras constitucionais, Daniel Sarmento e Cláudio Pereira discorrem que, a rigor, não existe um único critério a ser considerado "correto". Entretanto, os autores, juntamente ao entendimento de Humberto Ávila e de Ana Paula Barcellos, consignam que, "em casos excepcionais, e com grande cautela, até as regras constitucionais podem sujeitar-se a ponderações". 84

Nesse sentido, a mencionada doutrina extrai um exemplo de decisão - segundo ela, acertada - da jurisprudência do STF. Trata-se do julgamento do Habeas Corpus n. 89.417, de $2006^{85}$, onde se discutiu a possibilidade de não aplicação da regra constitucional que determina que a prisão em flagrante de um deputado estadual deve ser submetida ao crivo da respectiva Assembleia Legislativa - art. 27, $1^{\circ}$, c/c art. 53, $\S 2^{\circ}, \mathrm{CF}$. No referido caso, o HC

\footnotetext{
${ }^{80}$ NEVES, MARCELO. Entre Hidra e Hércules: princípios e regras constitucionais como diferença paradoxal do sistema jurídico. São Paulo: Editora WMF Martins Fontes, 2013, p. 89 e ss.

${ }^{81}$ NEVES, MARCELO. Entre Hidra e Hércules: princípios e regras constitucionais como diferença paradoxal do sistema jurídico. São Paulo: Editora WMF Martins Fontes, 2013, p. 89 e ss.

${ }^{82}$ NEVES, MARCELO. Entre Hidra e Hércules: princípios e regras constitucionais como diferença paradoxal do sistema jurídico. São Paulo: Editora WMF Martins Fontes, 2013, p. 89 e ss.

${ }^{83}$ NEVES, MARCELO. Entre Hidra e Hércules: princípios e regras constitucionais como diferença paradoxal do sistema jurídico. São Paulo: Editora WMF Martins Fontes, 2013, p. 89 e ss.

${ }^{84}$ SOUZA NETO, Cláudio Pereira de; SARMENTO, Daniel. Direito Constitucional: Teoria, história e métodos de trabalho. $2^{\mathrm{a}}$ ed. Belo Horizonte: Fórum, 2014, p. 387-388.

${ }^{85} \mathrm{HC}$ n. 89.417, rel. min. Cármen Lúcia, julgamento em 22-8-2006, Primeira Turma, DJ de 15-12-2006.
} 
foi impetrado contra o ato judicial que determinara a prisão do Presidente da Assembleia Legislativa do Estado de Rondônia, acusado de chefiar quadrilha onde participariam 23 dos 24 deputados estaduais daquela unidade federativa. Por sua vez, o STF reconheceu a singularidade do caso, entendendo que ali se justificava a não aplicação da regra em comento. Assim, o STF ponderou a regra com princípios relevantes, como a República, a moralidade e a democracia. De acordo com a relatora Ministra Carmen Lúcia:

\begin{abstract}
A norma constitucional que cuida da imunidade parlamentar e da proibição de prisão do membro de órgão legislativo não pode ser tomada em sua literalidade, menos ainda como regra isolada do sistema constitucional. Os princípios determinam a interpretação e aplicação corretas da norma, sempre se considerando os fins a que ela se destina. A Assembleia Legislativa do Estado de Rondônia, composta de vinte e quatro deputados, dos quais, vinte e três estão indiciados em diversos inquéritos, afirma situação excepcional e, por isso, não se há de aplicar a regra constitucional do art. 53, § $2^{\circ}$, da Constituição da República, de forma isolada e insujeita aos princípios fundamentais do sistema jurídico vigente. ${ }^{86}$
\end{abstract}

A partir desse caso, percebemos que, não obstante as regras devam normalmente ser aplicadas de modo tudo ou nada, extraordinariamente e mediante um pesado ônus

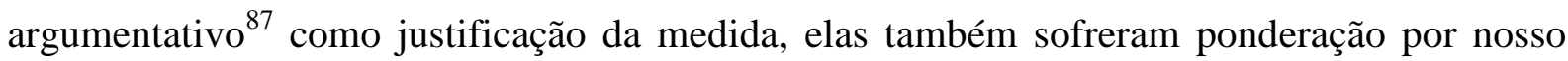
Tribunal.

\title{
2. QUAL É A CONTRIBUIÇÃO DAS REGRAS E DOS PRINCÍPIOS PARA O SISTEMA CONSTITUCIONAL?
}

\subsection{A CONSTITUIÇÃO COMO SISTEMA ABERTO DE REGRAS E PRINCÍPIOS}

Apesar de exercerem funções diferentes no cenário constitucional, as regras e os princípios são igualmente essenciais. Por isso, Gomes Canotilho muito bem caracteriza a Constituição como um sistema aberto de regras e princípios. ${ }^{88}$

Uma vez que propiciam maior amplitude para interpretações que considerem as especificidades do quadro empírico, os princípios possibilitam um melhor diálogo da Constituição com a realidade fática subjacente. Seu caráter plástico abre espaço para que a

\footnotetext{
${ }^{86}$ HC n. 89.417, rel. min. Cármen Lúcia, julgamento em 22-8-2006, Primeira Turma, DJ de 15-12-2006.

${ }^{87}$ SOUZA NETO, Cláudio Pereira de; SARMENTO, Daniel. Direito Constitucional: Teoria, história e métodos de trabalho. $2^{\text {a }}$ ed. Belo Horizonte: Fórum, 2014, p. 388.

${ }^{88}$ CANOTILHO, José Joaquim Gomes. Direito constitucional e teoria da Constituição. Coimbra: Almedina, 2003, p. 1036.
} 
solução mais justa no caso concreto possa penetrar a fim da concretização constitucional. É por tal motivo que muitos autores ${ }^{89}$ associam os princípios constitucionais ao ideal de justiça.

Contudo, tal afirmação não retira das regras constitucionais a possibilidade de elas serem fortemente inspiradas num ideário de justiça. Também não implica que em todos os princípios esse componente axiológico receba abundante destaque. No que tange à justiça, a diferença entre regras e princípios não se encontra nos respectivos conteúdos normativos, mas "no espaço construído pelo intérprete para buscá-la no caso concreto - maior nos princípios do que nas regras". É nesse sentido que Humberto Ávila associa as regras à justiça geral, e os princípios à justiça particular. $^{90}$

No campo hermenêutico, a maleabilidade dos princípios permite a articulação e o diálogo ou, até mesmo, a disputa de espaço de diferentes forças políticas e sociais, que apregoam ideologias e cosmovisões divergentes. Portanto, é cabível a afirmação de que a abertura semântica dos princípios confere maior abertura social à Constituição, que, por sua vez, torna-se mais receptiva ao pluralismo cultural e político, inerente às sociedades contemporâneas. $^{91}$

Ademais, a abertura dos princípios permite maior adaptação da Constituição às mudanças sociais, poupando, assim, a necessidade de frequentes alterações formais em seu texto. Desse modo, os princípios colaboram para o fenômeno da mutação constitucional ao longo do tempo.

2.2 A ESSENCIALIDADE DOS PRINCÍPIOS DIANTE DA CONSTRUÇÃO DE UMA IDENTIDADE CONSTITUCIONAL: A COMPLEXA TENSÃO ENTRE INCLUSÃO E EXCLUSÃO E A ABERTURA PARA A AFIRMAÇÃO DE DIREITOS FUNDAMENTAIS COMO A IGUALDADE E A LIBERDADE

De acordo com as palavras de Daniel Sarmento e de Cláudio Pereira, "sob o ângulo cultural, os princípios são fundamentais para enraizarem o sentimento constitucional do povo". 92 Tais autores atribuem boa parte do sucesso da ordem constitucional à sua capacidade

\footnotetext{
${ }^{89}$ Cf. BARCELLOS, Ana Paula. Ponderação, racionalidade e atividade jurisdicional. Rio de Janeiro: Renovar, 2005, p. 186-187; BARROSO, Luís Roberto. Curso de direito constitucional contemporâneo: os conceitos fundamentais e a construção do novo modelo. 2. Ed. São Paulo: Saraiva, 2010, p. 209.

${ }^{90}$ Cf. ÁVILA, Humberto. Neoconstitucionalismo: entre a ciência do direito e o direito da ciência. In: SOUZA NETO, Cláudio Pereira de; SARMENTO, Daniel; BINENBOJM, Gustavo (Org.). Vinte anos da Constituição Federal de 1988, p. 196-199.

${ }^{91}$ Cf. HÄBERLE, Peter. Pluralismo y Constitución: estudios de teoría constitucional de la sociedad abierta, p. 85-103 apud SOUZA NETO, Cláudio Pereira de; SARMENTO, Daniel. Direito Constitucional: Teoria, história e métodos de trabalho. $2^{\mathrm{a}}$ ed. Belo Horizonte: Fórum, 2014, p. 389.

${ }^{92}$ SOUZA NETO, Cláudio Pereira de; SARMENTO, Daniel. Direito Constitucional: Teoria, história e métodos de trabalho. $2^{\mathrm{a}}$ ed. Belo Horizonte: Fórum, 2014, p. 389.
} 
de "conquistar corações e mentes do cidadão comum". 93 No entanto, não há que se olvidar a importância das regras, que são cruciais para a segurança jurídica no seu processo de aplicação, aumentando a previsibilidade do Direito. Assim, é essencial para a operacionalidade do sistema jurídico que determinadas questões já estejam decididas com a devida clareza pela Constituição. ${ }^{94}$

Não obstante, tampouco podemos olvidar a lição aprendida após o excesso do Estado Social: que a pretensão de se regular todas as situações fadou-se ao fracasso, além do que a letra da lei deve ser interpretada para o bem de cada indivíduo pertencente ao contexto social.

Há que se buscar o equilíbrio na verificação da importância tanto de regras quanto de princípios no sistema jurídico atual, não se devendo assentar um modelo hermenêutico legalista - excessivamente rígido, refratário aos princípios e aos imperativos morais do constitucionalismo -, tampouco devemos menosprezar as regras constitucionais, sob pena de arriscar-nos à insegurança e ao arbítrio. Não obstante, ressaltamos que os juízes devem estar sempre atentos para a satisfação da exigência requerida pela comunidade de princípios, fruto do construto social democrático.

Ao adentrarmos ao tema concernente à identidade constitucional, percebemos que ele incide constante problematização frente aos regimes constitucionais contemporâneos. Isso porque, além de sua alterabilidade com o passar do tempo, ela encontra-se mergulhada "em complexas e ambíguas relações com outras identidades relevantes". 95

Nesse sentido, vale tecer breves considerações sobre a importância da atividade interpretativa judicial e de se alocar o tema rumo à formação de uma identidade constitucional.

Ao encorpar a linha do direito constitucional contemporâneo sectária do liberalismo defendido por John Rawls e por Ronald Dworkin, Michel Rosenfeld, em The identity of the constitutional subject, realiza uma análise em torno da natureza evasiva do sujeito e da identidade constitucionais, a posição do sujeito constitucional e a necessidade de sua reconstrução, e enfatiza a busca pelo sujeito constitucional do equilíbrio entre o "eu" e o "outro". O jurista reconhece que:

\footnotetext{
${ }^{93}$ SOUZA NETO, Cláudio Pereira de; SARMENTO, Daniel. Direito Constitucional: Teoria, história e métodos de trabalho. $2^{\text {a }}$ ed. Belo Horizonte: Fórum, 2014, p. 389.

${ }_{94}$ Cf. SCHAUER, Frederick. Playing by the Rules: a Philosofical Examination of Rule-Based Decision-Making in Law and in Life, p. 137-145.

${ }^{95}$ ROSENFELD, Michel. A identidade do sujeito constitucional. Texto original: The identity of the constitutional subject. In: Cardoso Law Review: A Mentalidade Pós-Moderna e o Direito, Nova Iorque: Yeshiva University Press, p. 1049-1109, Janeiro de 1995. Copyright: Yeshiva University e Michel Rosenfeld, p. 1.
} 
Um texto constitucional escrito é inexoravelmente incompleto e sujeito a múltiplas interpretações plausíveis. Ele é incompleto não somente porque não cobre todas as matérias que ele deveria idealmente contemplar, mas porque, além do mais, ele não é capaz de contemplar exaustivamente todas as questões concebíveis que podem ser levantadas a partir das matérias que ele acolhe. Mais ainda, precisamente em razão da incompletude do texto constitucional, as constituições devem permanecer abertas à interpretação; e isso, no mais das vezes, significa estarem abertas às interpretações conflitantes que pareçam igualmente defensáveis. ${ }^{96}$

Um dos desafios a ser percorrido pelo direito constitucional hodierno é reconhecer a abertura dos direitos fundamentais, bem como da Constituição formal, que se encontra em constante processo de construção e de reconstrução.

Os intérpretes constitucionais não podem se despir completamente de sua identidade nacional ou cultural. (...) A identidade constitucional surge como algo complexo, fragmentado, parcial e incompleto. Sobretudo no contexto de uma constituição viva, de uma living constitution, a identidade constitucional é o produto de um processo dinâmico sempre aberto à maior elaboração e à revisão. ${ }^{97}$

O pluralismo ganha maior relevância quando percebemos que o constitucionalismo não encontraria sentido na ausência daquele. Por derradeiro, há que se considerar produtiva, ainda que conflituosa, a tensão entre o pluralismo inerente ao constitucionalismo contemporâneo e a tradição - o confronto entre as identidades relevantes: identidade constitucional, identidade nacional, identidade étnica, identidade religiosa, identidades culturais.

Em uma comunidade completamente homogênea, com um único objetivo coletivo e sem uma concepção de que o indivíduo tenha em alguma medida direitos legítimos ou interesses distintos dos da comunidade como um todo, o constitucionalismo (...) seria supérfluo. ${ }^{98}$

O desafio é justamente este: O problema de uma identidade constitucional em um momento em que ela é necessariamente plural.

De tal modo, a identidade construída pela maioria deve coexistir com uma multiplicidade de particularidades relevantes. Mais que isso, deve dialogar com as demais

\footnotetext{
${ }^{96}$ ROSENFELD, Michel. A identidade do sujeito constitucional. Texto original: The identity of the constitutional subject. In: Cardoso Law Review: A Mentalidade Pós-Moderna e o Direito, Nova Iorque: Yeshiva University Press, p. 1049-1109, Janeiro de 1995. Copyright: Yeshiva University e Michel Rosenfeld, p. 1 e ss.

${ }^{97}$ ROSENFELD, Michel. A identidade do sujeito constitucional. Texto original: The identity of the constitutional subject. In: Cardoso Law Review: A Mentalidade Pós-Moderna e o Direito, Nova Iorque: Yeshiva University Press, p. 1049-1109, Janeiro de 1995. Copyright: Yeshiva University e Michel Rosenfeld, p. 4.

${ }^{98}$ ROSENFELD, Michel. A identidade do sujeito constitucional. Texto original: The identity of the constitutional subject. In: Cardoso Law Review: A Mentalidade Pós-Moderna e o Direito, Nova Iorque: Yeshiva University Press, p. 1049-1109, Janeiro de 1995. Copyright: Yeshiva University e Michel Rosenfeld, p. 3.
} 
identidades, de forma que se complementem, pois é inegável que a identidade constitucional necessita de referências oriundas das outras identidades relevantes.

É a partir do reconhecimento de que o sujeito e a matéria constitucionais são mais uma ausência do que uma presença, uma vez que carecem permanentemente de completude e de reconstrução, que se torna possível compreender a importância da incorporação de elementos de outras identidades, orientada pelo processo de reconstrução que, por sua vez, "busca alcançar um equilíbrio entre a assimilação e a rejeição das demais identidades relevantes". ${ }^{99}$

Já sabemos que uma tese defendida por Rosenfeld é a de que a identidade do sujeito constitucional se desenvolve em torno de um hiato, de uma ausência, e por isso, o autor encontra afinidades com a teoria psicanalítica de Freud e de Lacan, e com a teoria filosófica do sujeito de Hegel. Para este, "a questão do sujeito emerge da necessidade do confronto com

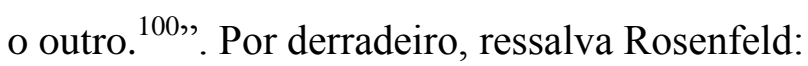

\begin{abstract}
O constitucionalismo moderno, por outro lado, não pode evitar o contraste entre o eu (self) e o outro como uma consequência do pluralismo que lhe é inerente. Em um nível, o eu (self) constitucional pluralista se enfrenta com o seu outro que é a tradição que mantinha integrada a ordem sociopolítica pré-moderna. Pode-se referir a esse outro como o "outro externo". ${ }^{101}$
\end{abstract}

O problema da exclusão das minorias clamou por políticas voltadas à assimilação cultural. E os conflitos emergentes entre distintos grupos étnicos, culturais e religiosos se intensificaram. As lutas por inclusão e reconhecimento são, para Habermas, verdadeiros "conflitos invisíveis", onde "a afirmação de identidades coletivas e o reconhecimento mútuo das diferenças são o que se encontra em questão". Por derradeiro, uma solução jurídica aceitável não pode visar "a síntese universal (de um todo) mas, ao contrário, à possibilidade da coexistência de uma multiplicidade de particularidades frequentemente incompatíveis". ${ }^{102}$

A questão da identidade constitucional demonstra-nos a rica e complexa tensão entre inclusão e exclusão, onde a visibilidade à exclusão "permite a organização e a luta pela

\footnotetext{
${ }^{99}$ ROSENFELD, Michel. A identidade do sujeito constitucional. Texto original: The identity of the constitutional subject. In: Cardoso Law Review: A Mentalidade Pós-Moderna e o Direito, Nova Iorque: Yeshiva University Press, p. 1049-1109, Janeiro de 1995. Copyright: Yeshiva University e Michel Rosenfeld, p. 6.

${ }^{100}$ ROSENFELD, Michel. A identidade do sujeito constitucional. Texto original: The identity of the constitutional subject. In: Cardoso Law Review: A Mentalidade Pós-Moderna e o Direito, Nova Iorque: Yeshiva University Press, p. 1049-1109, Janeiro de 1995. Copyright: Yeshiva University e Michel Rosenfeld, p. 7 . Ver Georg W.F. Hegel, Phenomenology of Spirit PP 175 - 96, pp. 109 -19 (Arnold V. Miller trans., Oxford Univ. Press 1979) (5th ed. 1952); Lacan, supra note 1, pp. 655 -56.

${ }^{101}$ Ibid., p. 7 e ss.

${ }^{102}$ HABERMAS, Jürgen. Notas sobre a tríade de Denninger: diversidade, segurança e solidariedade. Tradução livre, p. 5-6.
} 
conquista de concepções cada vez mais complexas e articuladas da afirmação constitucional da igualdade e da liberdade de todos". 103

Aqui, portanto, constata-se um grande desafio aos direitos fundamentais:

O primeiro e grande desafio é sabermos que se, por um lado, os direitos fundamentais promovem a inclusão social, por outro e a um só tempo, produzem exclusões fundamentais. A qualquer afirmação de direitos corresponde uma delimitação, ou seja, corresponde ao fechamento do corpo daqueles titulados a esses direitos, à demarcação do campo inicialmente invisível dos excluídos de tais direitos. 104

A teoria reconstrutiva de Dworkin, aplicada na interpretação jurídico-constitucional, determina que a tomada de decisão constitucional sempre se dá sob condições que excluem a possibilidade de uma determinação plena, o que torna a construção necessária. De fato, "a tomada de decisão constitucional envolve a construção na medida em que as questões constitucionais sempre requerem escolhas entre duas ou mais alternativas plausíveis". 105

Analisemos, sucintamente, o impacto da tomada de decisões na identidade constitucional de um país. A decisão da Suprema Corte dos Estados Unidos de 1973 no caso Roe v. Wade, por exemplo, ao reconhecer pela primeira vez um direito constitucional ao aborto, certamente envolveu uma construção criativa judicial. Esse ato de construção judicial exerceu um inquestionável e significativo impacto sobre a identidade constitucional dos Estados Unidos. O reconhecimento de um direito constitucional ao aborto "projeta uma imagem da identidade constitucional norte-americana notavelmente distinta da que teria surgido se a Suprema Corte houvesse se recusado a reconhecer esse direito". ${ }^{106}$

É possível afirmar que "todas as decisões constitucionalmente significativas produzem algum impacto na identidade constitucional” e por isso mesmo, requerem justificação. A interpretação e a atividade criacional introduzem novos elementos que exercem influência na composição das identidades constitucionais. Nesse sentido, a tarefa da reconstrução é a de

\footnotetext{
${ }^{103}$ CARVALHO NETTO, Menelick de; SCOTTI, Guilherme. Os Direitos Fundamentais e a (in)certeza do Direito: a produtividade das tensões principiológicas e a superação do sistema de regras. Belo Horizonte: Editora Fórum, 2011, p. 14.

${ }^{104}$ CARVALHO NETTO, Menelick de; SCOTTI, Guilherme. Os Direitos Fundamentais e a (in)certeza do Direito: a produtividade das tensões principiológicas e a superação do sistema de regras. Belo Horizonte: Editora Fórum, 2011, p. 14.

${ }^{105}$ ROSENFELD, Michel. A identidade do sujeito constitucional. Texto original: The identity of the constitutional subject. In: Cardoso Law Review: A Mentalidade Pós-Moderna e o Direito, Nova Iorque: Yeshiva University Press, p. 1049-1109, Janeiro de 1995. Copyright: Yeshiva University e Michel Rosenfeld, p. 13-15.

${ }^{106}$ ROSENFELD, Michel. A identidade do sujeito constitucional. Texto original: The identity of the constitutional subject. In: Cardoso Law Review: A Mentalidade Pós-Moderna e o Direito, Nova Iorque: Yeshiva University Press, p. 1049-1109, Janeiro de 1995. Copyright: Yeshiva University e Michel Rosenfeld, p. 13-15.
} 
harmonização dos novos elementos com os anteriormente existentes; ou, ainda, a recombinação de todos os elementos envolvidos em um quadro inteligível e persuasivo. ${ }^{107}$

Dworkin insiste que a interpretação judicial reconstrutiva deve ser pautada pela aceitação de determinados princípios deontológicos, tal como o direito de cada pessoa a ser tratada com igual consideração e respeito e dignidade, e a assunção da ideia de integridade do Direito enquanto "densificação vivencial do ideal da comunidade de princípio", é dizer, de "uma comunidade em que seus membros se reconhecem reciprocamente como livres e iguais e como co-autores das leis que fizeram para reger efetivamente a sua vida cotidiana em comum", assim como, em uma "dimensão diacrônica", a compreensão da sua história institucional "como um processo de aprendizado em que cada geração busca, da melhor forma que pode, vivenciar esse ideal" - de onde decorre a metáfora do romance em cadeia. ${ }^{108}$

Para Rosenfeld, a exigência da igual consideração e respeito é essencial para a autoidentidade constitucional, uma vez que "fornece um critério normativo amplamente aceitável que igualmente envolve tanto o $e u$ (self) quanto o outro, cujo vínculo comum é tão essencial para a auto-identidade constitucional." 109

Portanto, o Estado é portador de autoridade moral tão somente quando ele respeita o postulado da igual preocupação e respeito para com seus cidadãos. Tal ideia será posteriormente desenvolvida neste trabalho. ${ }^{110}$ Indubitavelmente, esse princípio "promove o mútuo reconhecimento entre o eu (self) e o outro, e mantém eu (self) e outro no mesmo patamar de dignidade". ${ }^{111}$

Sabemos que o postulado da igualdade implica em direito à diferença. Ao discorrer sobre o aspecto igualitário da igual proteção e da não discriminação, Habermas assevera que este "sempre importou em um igual direito à desigualdade". Nessa esteira, a legitimidade da norma jurídica dependerá do "filtro de um público discursivo", onde o debate público

\footnotetext{
${ }^{107}$ ROSENFELD, Michel. A identidade do sujeito constitucional. Texto original: The identity of the constitutional subject. In: Cardoso Law Review: A Mentalidade Pós-Moderna e o Direito, Nova Iorque: Yeshiva University Press, p. 1049-1109, Janeiro de 1995. Copyright: Yeshiva University e Michel Rosenfeld, p. 13 -15.

${ }^{108}$ CARVALHO NETTO, Menelick de; SCOTTI, Guilherme. Os Direitos Fundamentais e a (in)certeza do Direito: a produtividade das tensões principiológicas e a superação do sistema de regras. Belo Horizonte: Editora Fórum, 2011, p. 27-28.

${ }^{109}$ ROSENFELD, Michel. A identidade do sujeito constitucional. Texto original: The identity of the constitutional subject. In: Cardoso Law Review: A Mentalidade Pós-Moderna e o Direito, Nova Iorque: Yeshiva University Press, p. 1049-1109, Janeiro de 1995. Copyright: Yeshiva University e Michel Rosenfeld, p. 15.

${ }^{110}$ Vide Parte III do presente estudo.

${ }^{111}$ ROSENFELD, Michel. A identidade do sujeito constitucional. Texto original: The identity of the constitutional subject. In: Cardoso Law Review: A Mentalidade Pós-Moderna e o Direito, Nova Iorque: Yeshiva University Press, p. 1049-1109, Janeiro de 1995. Copyright: Yeshiva University e Michel Rosenfeld, p. 15 e ss.
} 
estabelecerá os "critérios segundo os quais os iguais devam ser tratados igualmente e os desiguais desigualmente". 112

Não obstante, devemos atentar-nos:

A igualdade do respeito às diferenças incluí e, ao mesmo tempo, exclui. Sempre que afirmamos quem somos nós, os titulares do direito à igualdade, fechamos o sujeito constitucional que, conforme nos ensina Michel Rosenfeld e requer o $\S 2^{\circ}$ do art. $5^{\circ}$ da Constituição da República, há que sempre permanecer aberto ao reconhecimento como igualdade de diferenças antes discriminadas e insustentáveis em um debate público quando questionadas. ${ }^{113}$

\section{COLISÃO ENTRE NORMAS CONSTITUCIONAIS: QUAIS OS LIMITES DOS DIREITOS FUNDAMENTAIS?}

\subsection{A DESABSOLUTIZAÇÃO DOS DIREITOS FUNDAMENTAIS}

O entendimento de conferir aos direitos fundamentais caráter absoluto encontrou alcance até o Século XVIII, sob a origem e influência de uma fundamentação jusnaturalista, sectária da noção racionalista do Direito Natural, e singular do pensamento de John Locke, no sentido de que qualquer restrição aos direitos fundamentais operava contra natura. ${ }^{114}$ De acordo com o estado de natureza de Locke, os indivíduos estão regulados pela razão, e nascem com os direitos naturais à vida, à liberdade e à propriedade privada.

Nascida em 12 de junho de 1776, a Declaração de Direitos de Virgínia ressaltava a natureza de direito absoluto ao direito fundamental à liberdade de expressão. Estabelecia sua 12 $2^{\text {a }}$ Seção: "That the freedom of the press is one of the great bulwarks of liberty, and can never be restrained but by despotic governments". ${ }^{115}$

No entanto, atualmente, resta superada a compreensão dos direitos fundamentais como direitos absolutos e ilimitados, inadmissíveis de serem restringidos. Inclusive, o Supremo Tribunal Federal acentuou que "não há, no sistema constitucional brasileiro, direitos ou garantias que se revistam de caráter absoluto (...)". ${ }^{116}$ De acordo com a doutrina de Francisco

\footnotetext{
${ }^{112}$ HABERMAS, Jürgen. Notas sobre a tríade de Denninger: diversidade, segurança e solidariedade. Tradução livre, p. 5.

${ }^{113}$ CARVALHO NETTO, Menelick de; SCOTTI, Guilherme. Os Direitos Fundamentais e a (in)certeza do Direito: a produtividade das tensões principiológicas e a superação do sistema de regras. Belo Horizonte: Editora Fórum, 2011, p.28.

${ }^{114}$ Cf. CAMAZANO, Joaquín Brage. Los Límites a los Derechos Fundamentales. Madrid: Dylinson, 2004.

115 [...] a liberdade de imprensa é um dos grandes baluartes da liberdade e não pode ser restringida jamais, a não ser por governos despóticos.

${ }^{116}$ RTJ 173/805-810, 807, Rel. Min. CELSO DE MELLO.
} 
Fernández Segado, “(...) el carácter limitado de los derechos es hoy una evidencia que no admite contestación alguna". 117

A admissão da restringibilidade e de limites aos direitos fundamentais, decorre, principalmente, na visão de Juan Echavarria ${ }^{118}$, do caráter universal ou geral desses direitos, bem como da imprescindível necessidade de coexistência desses direitos entre si ou com outros bens jurídicos constitucionalmente protegidos. Contrariamente, se fossem os direitos fundamentais considerados absolutos, tal ideia os conduziria a uma profunda ineficácia, impondo-se a sua limitação por questões até mesmo pragmáticas. ${ }^{119}$ A Corte Constitucional Italiana, por sua vez, afirmou ser o conceito de limite inerente ao conceito de direito, e, no âmbito do sistema jurídico, as diferentes situações de direito devem, necessariamente, limitarse, reciprocamente, a fim de que possam coexistir em uma comunidade civil bem ordenada:

[...] bisognerebbe ricordare che il concetto di limite é insito nel concetto di diritto e che nell'ambito dell'ordinamento le varie sfere giuridiche devono di necessità limitarsi reciprocamente, perché possano coesistere nell'ordinata convivenza civile. $^{120}$

Ademais, a limitação aos direitos fundamentais é um tema que encontra esboço desde a Declaração Universal dos Direitos Humanos - Déclaration des Droits de l'Homme et du Citoyen - que, no artigo 29.2 estabelece:

No exercício deste direito e no gozo destas liberdades ninguém está sujeito senão às limitações estabelecidas pela lei com vista exclusivamente a promover o reconhecimento e o respeito dos direitos e liberdades dos outros e a fim de satisfazer as justas exigências da moral, da ordem pública e do bem-estar numa sociedade democrática. ${ }^{121}$

Assim, em 1789, já se reconhecia que o exercício dos direitos fundamentais, constitucionalmente consagrados, não é absoluto, pelo contrário, sendo passíveis de regulação e de certas limitações.

A doutrina e a jurisprudência brasileira bem como o Direito Comparado posicionamse majoritariamente no sentido da possibilidade de as normas constitucionais colidirem entre

\footnotetext{
${ }^{117}$ SEGADO, Francisco Fernández. La dogmática de los derechos humanos. Lima: Ediciones Jurídicas, 1994, p. 100 e ss.

${ }^{118}$ ECHAVARRIA, Juan Jose Solozabal. Algunas questiones básicas de la teoría de los derechos fundamentales. In: Revista de Estudios Políticos. Nueva Época: Madrid, n. 71, p. 98, ene./mar. 1991.

${ }^{119}$ RENUCCI, Jean-François. Droit européen des droits de l'homme. Paris: L.G.D.J., 1999, p. 369 apud CHEQUER, Cláudio. A liberdade de expressão como direito fundamental preferencial prima facie: análise crítica e proposta de revisão ao padrão jurisprudencial brasileiro. Rio de Janeiro: Lumen Juris, 2011, p. 31.

${ }^{120}$ REPUBBLICA ITALIANA, LA CORTE COSTITUZIONALE. Sentenza n. 1, anno 1956.

${ }^{121}$ DECLARAÇÃO UNIVERSAL DOS DIREITOS DO HOMEM. Disponível em: $<$ http://www.humanrights.com/pt/what-are-human-rights/universal-declaration-of-human-rights.html>. Acesso em 20 dez. 2015.
} 
si. Nesse sentido, reconhece-se que o fenômeno da colisão entre normas constitucionais é corriqueiro, especialmente em uma sociedade plural e complexa, que demanda variados meios de inserção e de luta pela concretização de compromissos constitucionais.

A interpretação jurídica é exercício que envolve inúmeras dificuldades, tais como: a linguagem aberta dos textos jurídicos; as colisões entre normas constitucionais e os diferentes métodos de interpretação constitucional.

Nesse ínterim, a Constituição se utiliza de diversas cláusulas abertas, incluindo-se aí conceitos jurídicos indeterminados (calamidade pública, relevância e urgência, p.e.) e princípios (dignidade da pessoa humana e moralidade administrativa).

Cláusulas de tal tipo abrem espaço para distintas construções hermenêuticas, a depender da pré-compreensão do intérprete. É o que se chama de reasonable disagreement/ moral disagreement - desacordo moral razoável. ${ }^{122}$

Daniel Sarmento e Cláudio Pereira reúnem alguns fatores que, para eles, contribuem para o aumento do referido fenômeno de colisão: a extensão da Constituição, uma vez que quanto mais normas existirem, maior será a possibilidade da existência de conflitos entre elas; a natureza aberta da linguagem constitucional, por "multiplicar os riscos de que uma mesma hipótese fática possa ser enquadrada, simultaneamente, no campo de incidência de normas diferentes, que apontem soluções distintas para o caso"; o caráter compromissório da Constituição, por aumentar a possibilidade de atritos entre ideologias e visões de mundo diferentes. ${ }^{123}$

Para os autores, a Constituição da República de 88 possui uma quantidade vastíssima de normas, sendo que, muitas delas, possuem linguagem bastante vaga, além de ostentar uma indiscutível natureza compromissória. ${ }^{124}$

No entanto, parece-nos inviável a pretensão de regulação de todas as possíveis condutas por meio de regras abstratas, especialmente a partir da admissão da estrutura aberta da linguagem, inerente e inevitável a ela. Cabe, portanto, ao sistema jurídico lidar com essa indeterminação - “diante de sua tarefa inescapável de decidir". ${ }^{125}$

\footnotetext{
${ }^{122}$ MCMAHON, Christopher. Reasonable disagreement: a theory of political morality, 2009; e TERSMAN, Folke. Moral disagreement, 2006 apud BARROSO, Luís Roberto. JURISDIÇÃO CONSTITUCIONAL: A TÊNUE FRONTEIRA ENTRE O DIREITO E A POLÍTICA. Disponível em: <http://www.luisrobertobarroso.com.br/?p=1000>. Acesso em: 2 mar. 2014.

${ }^{123}$ SOUZA NETO, Cláudio Pereira de; SARMENTO, Daniel. Direito Constitucional: Teoria, história e métodos de trabalho. 2. ed. Belo Horizonte: Fórum, 2014, p. 495.

${ }^{124}$ SOUZA NETO, Cláudio Pereira de; SARMENTO, Daniel. Direito Constitucional: Teoria, história e métodos de trabalho. 2. ed. Belo Horizonte: Fórum, 2014, p. 495.

${ }^{125}$ CARVALHO NETTO, Menelick de; SCOTTI, Guilherme. Os Direitos Fundamentais e a (in)certeza do Direito: a produtividade das tensões principiológicas e a superação do sistema de regras. Editora Fórum, 2011, p.17.
} 
Por sua inegável relevância, o tema em comento atraiu especial atenção por parte da doutrina brasileira. Vale mencionar autores como Paulo Gonet Branco ${ }^{126}$, Emerson Garcia ${ }^{127}$, Jane R. Gonçalves Pereira ${ }^{128}$, Wilson Antônio Steinmetz ${ }^{129}$, Daniel Sarmento ${ }^{130}$, entre outros.

Nítida está a complexidade do tema, visto que ele entrelaça os campos político, jurídico e filosófico, abordando questões polêmicas como os limites ao ativismo judicial impostos pela democracia e pela separação de poderes, a possibilidade de comparação racional entre bens e valores carregados de excessiva heterogeneidade ${ }^{131}$, e a justa medida necessária para equacionar a tensão existente entre os direitos do indivíduo e os da coletividade.

É certo que a colisão pode ocorrer entre diferentes tipos de normas: há colisões entre princípios, entre regras, e entre princípio e regra. Contudo, o campo dos direitos fundamentais releva-se mais fecundo.

Superado tal debate, contemporaneamente, passa-se a discutir se a limitação do direito fundamental é inerente ao próprio direito previsto como fundamental ou se decorre de fatores externos - outros direitos fundamentais ou bens jurídicos constitucionais.

A depender da resposta, tal questionamento levará o intérprete a direções distintas. Portanto, é de suma importância entender o posicionamento de determinado caso frente ao âmbito de proteção ao direito fundamental. Nesse sentido, Joaquín Camazano ${ }^{132}$ explica que se entendemos que determinada situação não deve ser tutelada por estar fora do âmbito de proteção de um determinado direito fundamental - se entendemos que o direito fundamental à liberdade de expressão não tutela a veiculação de uma informação inverídica, por exemplo -, essa situação pode ser rejeitada por não existir em relação a ela o correspondente direito naquela hipótese concreta. Enquanto isso, estando-se frente a uma situação protegida, ainda que prima facie, por determinado direito fundamental, mas que, a depender das circunstâncias concretas, puder vir a violar outro direito fundamental, a solução não advirá do sacrifício total

\footnotetext{
${ }^{126}$ BRANCO, Paulo Gustavo Gonet. Juízo de ponderação na jurisdição constitucional. São Paulo: Saraiva, 2009.

${ }^{127}$ GARCIA, Emerson. Conflito entre normas constitucionais: esboço de uma teoria geral. Rio de Janeiro: Lumen Juris, 2008.

${ }^{128}$ PEREIRA, Jane Reis Gonçalves. Interpretação constitucional e direitos fundamentais. Rio de Janeiro: Renovar, 2006.

${ }^{129}$ STEINMETZ, Wilson Antônio. Colisão de direitos fundamentais e o princípio da proporcionalidade. Porto Alegre: Livraria do Advogado, 2001.

${ }^{130}$ SARMENTO, Daniel. A ponderação de interesses na Constituição Federal. Rio de Janeiro: Lumen Juris, 1999.

${ }^{131}$ Cf. BERNAL PULIDO, Carlos. El principio de proporcionalidad y los derechos fundamentales. 3.ed. Madrid: Centro de Estudios Constitucionales, 2007, p. 182-189.

${ }^{132}$ CAMAZANO, Joaquín Brage. Los Límites a los Derechos Fundamentales. Madrid: Dylinson, 2004, p. 256.
} 
de um dos direitos do conflito, uma vez que o núcleo essencial de um direito fundamental não está sujeito à ponderação. ${ }^{133}$

A partir do conhecimento do conteúdo dos direitos fundamentais, faz-se imprescindível uma análise em torno das teorias que estudam a possibilidade lógica de restrição a esses direitos. Nesse cenário, são duas as principais teorias desenvolvidas: i) a teoria interna ou concepção estrita dos limites dos Direitos Fundamentais; ii) a teoria externa ou concepção ampla dos limites dos Direitos Fundamentais.

\subsection{A TEORIA INTERNA DOS LIMITES DOS DIREITOS FUNDAMENTAIS}

\subsubsection{Considerações gerais}

Também intitulada de "concepção estrita do conteúdo dos direitos fundamentais", conforme preleciona Manuel Medina ${ }^{134}$, essa teoria apregoa que a Constituição já determina prévia e definitivamente o conteúdo de todos os direitos fundamentais, fixando, ainda, todos os seus limites. Desse modo, o conteúdo de todo direito fundamental já viria limitado pela própria Constituição, em razão da própria natureza de cada direito e de sua respectiva função social, conforme as palavras de Francisco Segado, a saber: "Los límites intrínsecos derivan de la propia naturaleza de cada derecho y de su función social."

Esses direitos apresentariam o que a doutrina chama de limites imanentes, a saber: os limites imanentes dos direitos fundamentais significam que tais direitos, "por estarem reconhecidos no interior do ordenamento jurídico, devem conciliar-se com outros bens que o ordenamento protege e não podem ser tutelados de forma absoluta frente a estes". ${ }^{136}$

Assim, conquanto não definidos no texto constitucional, os direitos fundamentais poderiam ser descobertos, mediante uma interpretação teleológica e sistemática da Lei Fundamental, que levasse em consideração os fins que motivam a proteção de cada direito, bem como todo o universo de outros bens também constitucionalmente protegidos. Esses

\footnotetext{
${ }^{133}$ ANDRADE, José Carlos Vieira. Os direitos fundamentais na Constituição portuguesa de 1976. Coimbra: Livraria Almedina, 1998, p. 217.

${ }^{134}$ Cf. MEDINA GUERRERO, Manuel. La vinculación negativa del legislador a los derechos fundamentales. Madrid: Ciencias Jurídicas, 1996, p. 93.

${ }^{135}$ SEGADO, Francisco Fernández. La teoría jurídica de los derechos fundamentales en la doctrina constitucional. In: "Revista Española de Derecho Constitucional", Madrid, n. 39, Septiembre/Diciembre, 1993, p. 236-237. Disponível em: < http://www.cepc.gob.es/gl/publicaci\%C3\%B3ns/revistas/revistaselectronicas?IDR=6\&IDN=341\&IDA=25145 >. Acesso em 4 nov. 2014.

${ }^{136}$ MARTÍN-RETORTILLO BAQUER, Lorenzo; OTTO Y PARDO, Ignacio. Derechos fundamentales y Constitución. Madrid: Editorial Civitas S.A., 1992, p. 110.
} 
limites imanentes, por serem inerentes às normas que consagram os direitos fundamentais, poderiam ser "explicitados" pelo legislador ou por decisões judiciais. ${ }^{137}$

O campo da interpretação judicial, sob a ótica da teoria em comento, compreende então que se o direito fundamental já está estabelecido prévia e definitivamente pelo constituinte, incorporando-se a um sistema único e harmônico de normas jurídicas, resta excluída a possibilidade de conflito entre direitos fundamentais. Nesse sentido, o que poderá ocorrer é a hipótese concreta ser resolvida pela aplicação adequada de apenas um dos direitos fundamentais potencialmente aplicáveis ao caso, tratando-se de mero caso de interpretação sistemática e unitária da Constituição. Para os professores Martín-Retortillo Baquer e Ignacio Otto y Pardo ${ }^{138}$ :

\begin{abstract}
Se se delimita o alcance da proteção que presta o direito fundamental, os problemas tratados como limitação para proteger outros bens constitucionais mostram ser em realidade, quando se trata verdadeiramente de bens de índole constitucional, problemas de interpretação sistemática e unitária da Constituição e que não é preciso ponderação alguma de bens e valores, nem consequentemente hierarquização dessa natureza, sim um exame pormenorizado do conteúdo de cada uma das normas.
\end{abstract}

Por derradeiro, ao quedar-se diante de um caso concreto, o intérprete adepto à teoria interna dos direitos fundamentais deverá analisar o conteúdo do direito fundamental previamente disposto pelo constituinte e, então, verificar qual o direito fundamental aplicável àquele caso, de modo que apenas um direito fundamental será adequado, não mais. Caberá ao intérprete, assim, reconhecer a demarcação precisa de cada direito fundamental, inexistindo a possibilidade de dois direitos fundamentais serem aplicados adequadamente, de modo simultâneo.

Emprestemo-nos das palavras de Gloria-Patricia L. Mesa, ao comentar a obra de Carlos Bernal Pulido:

Por su parte las teorías internas conciben a los derechos fundamentales como
entidades normativas cuyo contenido viene delimitado originariamente con carácter
definitivo, cuyos «límites» (si es que se admite esta forma de hablar) no provienen
de fuera, sino que son «inmanentes» al derecho mismo. (...) Así pues, desde el
enfoque propuesto por la teoría interna, la tarea del Tribunal Constitucional se
reduce a «descubrir» el contenido originario o verdadero del derecho fundamental
relevante en el caso y establecer si la ley enjuiciada afecta o no una posición
perteneciente al ámbito normativo del derecho en cuestión. ${ }^{139}$

\footnotetext{
${ }^{137}$ SOUZA NETO, Cláudio Pereira de; SARMENTO, Daniel. Direito Constitucional: Teoria, história e métodos de trabalho. 2. ed. Belo Horizonte: Fórum, 2014, p. 498.

${ }^{138}$ Cf. MARTÍN-RETORTILLO BAQUER, Lorenzo; OTTO Y PARDO, Ignacio. Derechos fundamentales y Constitución. Madrid: Editorial Civitas S.A., 1992, p. 143 apud CHEQUER, Cláudio. A liberdade de expressão como direito fundamental preferencial prima facie: análise crítica e proposta de revisão ao padrão jurisprudencial brasileiro. Rio de Janeiro: Lumen Juris, 2011, p. 46.

${ }_{139}$ LOPERA MESA, Gloria-Patricia. El principio de proporcionalidad y los dilemas del constitucionalismo. Comentario al libro de CARLOS BERNAL PULIDO: El principio de proporcionalidad y los derechos
} 
Friedrich Müller é sectário da teoria interna dos direitos fundamentais. Para ele, no cenário constitucional, deve-se manter firme o efeito esclarecedor e estabilizador da redação da norma como fator imprescindível ao Estado de Direito, devendo-se considerar os limites traçados pelo seu próprio texto como mero ponto de partida para a solução de um problema, de modo que a normatividade dos direitos fundamentais não se esgote no texto da norma. ${ }^{140}$ Nesse sentido, de acordo com as palavras de Friedrich Müller:

El texto determina los límites extremos de posibles variantes en el significado. Más allá de dichos límites no es lícito que los elementos del ámbito normativo, a menudo sólo insinuados en los preceptos constitucionales mediante palabras clave (...) se conviertan en el factor decisivo de la aplicación jurídica. ${ }^{141}$

As disposições normativas, portanto, não podem ser aplicadas como prescrições cerradas em si mesmas, mas devem ser concretizadas diante do caso concreto.

Assim, não é somente através das disposições normativas que se obtém a concreção das disposições constitucionais - em especial, de direitos fundamentais -, mas, principalmente, mediante as ações exercidas pelos titulares do Poder Legislativo, do Poder Executivo, e do Poder Judiciário. ${ }^{142}$

Por conseguinte, nítido está que a teoria interna dos direitos fundamentais rejeita a teoria da ponderação de princípios, segundo a qual dois direitos fundamentais podem, inegavelmente, entrar em rota de colisão diante de uma situação concreta. A técnica da ponderação, conforme ensina Alexy ${ }^{143}$, e nas palavras de Carlos Bernal Pulido:

(...) es únicamente una estructura por medio de la cual no se establece una relación absoluta, sino «una relación de precedencia condicionada» entre los principios, a la luz de las circunstancias del caso, a fin de determinar el sentido de la decisión judicial $^{144}$.

fundamentales, Madrid, Centro de Estudios Políticos y Constitucionales, 2003. In: Revista Española de Derecho Constitucional, Nueva Época, ISSN: 0211-5743, n. 73, enero-abril (2005), p. 389.

${ }^{140}$ MÜLLER, Friedrich. Tesis acerca de la estructura de las normas jurídicas. Traducción de Luis Villacorta Mancebo. Revista Española de Derecho Constitucional. Año 9. N. 27. Septiembre-Diciembre, 1989, p. p. 125.

${ }^{141}$ MÜLLER, Friedrich. Tesis acerca de la estructura de las normas jurídicas. Traducción de Luis Villacorta Mancebo. Revista Española de Derecho Constitucional. Año 9. N. 27. Septiembre-Diciembre, 1989, p. p. 125.

${ }^{142}$ CARA, Juan Carlos Gavara de. Derechos Fundamentales y Desarrollo Legislativo. La garantía del contenido esencial de los derechos fundamentales en la Ley Fundamental de Bonn. Madrid: Centro de Estudios Constitucionales, 1994, p. 107 e ss.

${ }^{143}$ ALEXY, Robert. Teoria de los derechos fundamentales. Madrid: Centro de Estudios Constitucionales, 1997, p. 269 e ss.

${ }^{144}$ PULIDO, Carlos Bernal. La Racionalidad de la Ponderación. In: Revista Española de Derecho Constitucional, ISSN: 0211-5743, n. 77, mayo-agosto, 2006, p. 61. 
Resta equivocada, portanto, a ideia de ponderação de princípios, sob a ótica da teoria interna. Logo, os direitos fundamentais, uma vez constitucionalmente tipificados e, por constituírem a decorrente eficácia normativa, revestem-se de caráter deontológico. ${ }^{145}$

Ao discorrer a respeito da teoria interna dos direitos fundamentais, Alexy assevera que sua base de sustentação não considera a existência de dois elementos, a saber, o direito e sua restrição, mas apenas de um deles: “o direito com um determinado conteúdo". Assim, "o conceito de restrição é substituído pelo conceito de limite". ${ }^{146}$

Desse modo, e, nas palavras de Cláudio Chequer, "para os adeptos da teoria interna, a ponderação não cumpre com um mínimo de racionalidade metodológica, tratando-se de um critério subjetivo e extremamente irracional". ${ }^{147}$ Observa o autor que os direitos fundamentais, sob tal perspectiva, não são absolutos, uma vez que se admite a existência de limites.

Com o intento de fundamentar o acerto da teoria interna dos direitos fundamentais, os professores Martín-Retortillo Baquer e Ignacio Otto y Pardo trazem à tona a decisão do Tribunal Constitucional da Espanha, a STC 2/1982. A decisão determina a imposição de pena por coações ocorridas no curso de uma reunião, dispensando, em absoluto, de argumentação com os limites do correspondente direito, por uma óbvia razão: "a de que o direito de reunião não compreende conceitualmente o direito de exercer coações sobre os demais". ${ }^{148}$

E, ainda, afirmam os autores, a sanção imposta a um funcionário que cedeu ao seu trabalho para assistir a uma missa, por exemplo, não corresponde a limitação alguma aos direitos fundamentais em questão, uma vez que esses direitos apenas não abraçam as hipóteses concretas. ${ }^{149}$

Autores como José María Guanter e Carlos Soría consideram inoportuno o termo limitação quando referido a um direito fundamental. Isso porque o direito à liberdade de

\footnotetext{
${ }^{145}$ HABERMAS, Jürgen. Direito e democracia: entre facticidade e validade, vol. I, 2.ed., tradução: Flávio Beno Siebeneichler. Rio de Janeiro: Tempo Brasileiro, 2012, p. 314 e ss.

${ }^{146}$ Cf. Peter Häberle, Die Wesensgehaltgarantie, p. 126 apud ALEXY, Robert. Teoria dos Direitos Fundamentais, 2. ed., Tradução de Virgílio Afonso da Silva da $5^{a}$ edição alemã Theorie der Grundrechte. São Paulo: Malheiros Editores, 2009, p. 277.

${ }^{147}$ CHEQUER, Cláudio. A liberdade de expressão como direito fundamental preferencial prima facie: análise crítica e proposta de revisão ao padrão jurisprudencial brasileiro. Rio de Janeiro: Lumen Juris, 2011, p. 47.

${ }^{148}$ MARTÍN-RETORTILLO BAQUER, Lorenzo; OTTO Y PARDO, Ignacio. Derechos fundamentales y Constitución. Madrid: Editorial Civitas S.A., 1992, p. 138 apud CHEQUER, Cláudio. A liberdade de expressão como direito fundamental preferencial prima facie: análise crítica e proposta de revisão ao padrão jurisprudencial brasileiro. Rio de Janeiro: Lumen Juris, 2011, p. 48.

${ }_{149}$ MARTÍN-RETORTILLO BAQUER, Lorenzo; OTTO Y PARDO, Ignacio. Derechos fundamentales y Constitución. Madrid: Editorial Civitas S.A., 1992, p. 139 apud CHEQUER, Cláudio. A liberdade de expressão como direito fundamental preferencial prima facie: análise crítica e proposta de revisão ao padrão jurisprudencial brasileiro. Rio de Janeiro: Lumen Juris, 2011, p. 48.
} 
expressão, por exemplo, uma vez que é inerente a uma pessoa, não tolera que nada nem ninguém o limite a partir de fora. ${ }^{150}$

O abuso a uma liberdade, portanto, configura-se perigoso para a coletividade e para o direito fundamental em si, enquanto instituição, de modo que se pode facilmente compreender que um abuso de um direito não pertence, desde o princípio, ao conteúdo do direito fundamental. Por derradeiro, leis que impedem o abuso não consistem em "restrições" a um direito, já que a inadmissibilidade de um abuso de direito advém da própria natureza do direito em questão, "sendo algo que se fusiona com a dimensão institucional dos direitos fundamentais". ${ }^{151}$ Assim, no âmbito dos direitos fundamentais, as regulações legislativas qualificam-se como conformação e determinação conforme a essência dos direitos fundamentais, nunca como uma restrição. ${ }^{152}$

A teoria interna remete alguns autores à diretriz de busca pela concordância prática entre normas constitucionais em tensão. De acordo com o princípio da concordância prática, diante de um aparente conflito entre preceitos constitucionais que apontem para diferentes direções para a solução de um determinado caso, caberá ao intérprete buscar a harmonização no caso concreto. Para Konrad Hesse, "os bens jurídicos constitucionalmente protegidos devem ser coordenados de tal modo na solução do problema que todos eles conservem a sua essência", sem o recurso à ponderação de bens ou de valores, que poderia prejudicar a unidade da Constituição. ${ }^{153}$

No entanto, vale lembrar que, apesar da usual adoção pela doutrina brasileira da concordância prática como um princípio de interpretação constitucional correlato à ponderação de interesses, na doutrina germânica, de onde se originam essas categorias, elas são antagônicas. Isso porque os adeptos ao uso da concordância prática tendem a rejeitar a ponderação, conforme elucida Virgílio Afonso da Silva. ${ }^{154}$ Contudo, na opinião de autores como Cláudio Pereira, isso não exclui a possibilidade da busca pela combinação entre a concordância prática e a ponderação, numa espécie de sincretismo metodológico:

\footnotetext{
${ }^{150}$ DESANTES GUANTER, José María; SORÍA, Carlos. Los límites de la información: la información en la jurisprudencia del Tribunal Constitucional, las 100 primeras sentencias. Madrid: Asociación de Prensa de Madrid, 1991, p. 62-63.

${ }^{151}$ CHEQUER, Cláudio. A liberdade de expressão como direito fundamental preferencial prima facie: análise crítica e proposta de revisão ao padrão jurisprudencial brasileiro. Rio de Janeiro: Lumen Juris, 2011, p. 48-49.

${ }^{152}$ HÄBERLE, Peter. La garantía del contenido esencial de los derechos fundamentales en la ley fundamental de Bonn. Una contribución a la concepción institucional de los derechos fundamentales y a la teoría de la reserva de la ley. Madrid: Dykinson-Constitucional, 2003, p. 118-119.

${ }^{153}$ HESSE,Konrad. La interpretación de la Constitución. In: HESSE,Konrad. Escritos de derecho constitucional. Traducción de Pedro Cruz Villalón. 2. Ed. Madrid: Centro de Estudios Constitucionales, 1992, p. 45-46.

${ }^{154}$ SILVA, Virgílio Afonso da. Interpretação constitucional e sincretismo metodológico. In: SILVA, Virgílio Afonso da (Org.) Interpretação Constitucional. Rio de Janeiro: Malheiros, 2005, p. 115-144; p. 127-128.
} 
primeiramente, recorre-se à concordância prática com o fim de lograr a harmonização entre as normas constitucionais em jogo no caso concreto; e, caso tal método se revele inviável, passase à outra fase do processo de concretização, que clamará pelo uso da ponderação. ${ }^{155}$

Vale também citar a posição de Jürgen Habermas e de Klaus Günther na presente discussão. ${ }^{156}$ Tais autores não negam a possibilidade de colisão entre normas constitucionais, não se classificando, assim, como defensores da categorização. Apesar disso, eles rechaçam a ponderação, acreditando ser o exame exaustivo da hipótese fática realizado pelo intérprete, bem como das alternativas jurídicas à disposição para a solução do caso, a fim de que se defina qual a norma mais adequada à situação concreta, como a melhor forma de proceder diante de normas constitucionais a priori incidentes sobre determinado caso. Assim, ao contrário do que ocorreria com o emprego da ponderação, o juízo de adequação é compatível com a função jurisdicional, que deve considerar princípios jurídicos não como normas impositivas, mas como valores otimizáveis.

Destaque-se, por sua vez, a perspectiva trazida por Dworkin segundo a qual a tensão entre normas é vista como produtiva. Em "Justice for Hedgehogs", Dworkin utiliza-se de uma citação do dramaturgo grego Arquíloco que, por sua vez, afirmou, em célebre passagem: “A raposa sabe muitas coisas, e o ouriço sabe uma só, mas o que o ouriço sabe é muito importante". É nesse momento que Dworkin sustenta a tese principal da unidade do valor. ${ }^{157}$ Em apertada síntese ${ }^{158}$, o jusfilósofo norte-americano propõe uma interpretação coerente com os valores morais que melhor justifiquem a trajetória político-constitucional de um Estado, de modo que, se assim forem interpretadas as normas constitucionais, o conflito é entendido como produtivo. A Justiça constitucional, para Dworkin, é uma Justiça de ouriço.

É nesse sentido que Dworkin se opõe à ideia de que liberdade e igualdade entram em colisão ${ }^{159}$, afirmando que elas não são virtudes independentes, "mas aspectos do mesmo ideal de associação política". 160

\footnotetext{
${ }^{155}$ SOUZA NETO, Cláudio Pereira de. Ponderação de princípios e racionalidade das decisões judiciais: coerência, razão pública, decomposição analítica e standards de ponderação. Boletim Científico da Escola Superior do Ministério Público da União, v. 15, p. 207-227.

${ }^{156}$ Vide: HABERMAS, Jürgen. Direito e democracia: entre facticidade e validade, vol. I, 2.ed., tradução: Flávio Beno Siebeneichler. Rio de Janeiro: Tempo Brasileiro, 2012, p. 314-330; e Günther, Klaus. Teoria da argumentação no direito e na moral: justificação e aplicação. Tradução de Cláudio Molz. São Paulo: Landy, 2004, p. 299-414.

${ }^{157}$ DWORKIN, Ronald. A raposa e o porco-espinho: justiça e valor. Tradução de Marcelo Brandão Cipolla. São Paulo: Editora WMF Martins Fontes, 2014, p. 180.

${ }^{158}$ A teoria em comento será melhor desenvolvida na Parte III deste trabalho

${ }^{159}$ A referida ideia será melhor desenvolvida na Parte III deste trabalho

${ }^{160}$ DWORKIN, Ronald. Sovereign Virtue: The Theory and Practice of Equallity. Cambridge; London: Harvard University Press, 2000, p. 182.
} 
Ao defender sua teoria, Dworkin admite a existência de um conflito aparente, que merece ser reinterpretado constantemente em nome da responsabilidade moral. Para ele, o "nosso pensamento se direciona para a unidade, não para a fragmentação. Qualquer que seja a nossa decisão, demos um passo rumo a uma compreensão mais integrada de nossas responsabilidades morais". Assim, "os conflitos aparentes são inevitáveis, mas podemos ter a esperança de que sejam apenas ilusórios e temporários", de modo que o apelo ao rearranjo conceitual colabora para que esses conflitos sejam eliminados. Nesse ínterim, Dworkin propõe uma interpretação capaz de reconciliar os valores de um jeito diferente: "demonstrando que o conflito é, no fundo, uma colaboração". 161

Em linhas gerais, é dessa forma que Dworkin pretende descrever um método - e não uma metafísica, em suas palavras - que aponte para um processo interpretativo integrativo, que "busca compreender cada parte e cada filamento do valor à luz das outras partes e filamentos". 162

Tendo em vista que, para Dworkin, todas as exceções são internas ao direito ou trunfo envolvido ${ }^{163}$, é possível classificar tal posicionamento, quanto à admissão de exceções aos trunfos, como inserido numa teoria interna, "uma vez que defende que todas as exceções aparentes a um determinado trunfo são, na verdade, internas a ele". ${ }^{164}$

Devemos esclarecer que a teoria interna exige uma leitura principiológica e sistêmica da Constituição, uma vez que ela é coerente com a visão de integridade do Direito. Ora, independentemente de menções externas pela Constituição, por exemplo, todo direito individual deve cumprir uma função social, o que é intrínseco ao seu próprio sentido. $\mathrm{O}$ sentido - interno - de um direito fundamental é a própria densificação de valores clamados pela própria comunidade de princípios. Portanto, a teoria em comento possibilita ao intérprete localizar a existência de pretensões abusivas, que pretendem travestir-se por trás das normas, aparentando um direito.

\subsubsection{Principais críticas à teoria interna dos limites dos direitos fundamentais}

\footnotetext{
${ }^{161}$ DWORKIN, Ronald. A raposa e o porco-espinho: justiça e valor. Tradução de Marcelo Brandão Cipolla. São Paulo: Editora WMF Martins Fontes, 2014, p. 180-183.

162 DWORKIN, Ronald. A raposa e o porco-espinho: justiça e valor. Tradução de Marcelo Brandão Cipolla. São Paulo: Editora WMF Martins Fontes, 2014, p. 180-183.

${ }^{163}$ DWORKIN, Ronald. Justice for Hedgehogs. Cambridge, MA: Harvard University Press, 2011, p. 413.

${ }^{164}$ COSTA NETO, João. Entre Cila e Caríbdis: a liberdade de expressão em meio ao conflito entre a discricionariedade do Legislador e a intensidade do controle exercido pelo Juiz Constitucional. São Paulo: Saraiva, no prelo.
} 
Uma das principais críticas à teoria interna dos direitos fundamentais é a de que esta acaba por reduzir tanto o conteúdo dos direitos fundamentais, que muitas situações não estão por eles contempladas. Diante da limitação a priori do âmbito de proteção dos direitos fundamentais, restringindo-o excessivamente, a teoria em comento permitiria que "certas posições relevantes do indivíduo fiquem completamente desguarnecidas". ${ }^{165}$

Além disso, a doutrina de Daniel Sarmento e de Jane Pereira, por exemplo, apontam que a teoria interna não exclui o risco de arbítrio judicial na definição do campo de incidência de cada norma constitucional. ${ }^{166}$ Nesse sentido:

\begin{abstract}
A dimensão constitutiva, criadora, da decisão judicial não é eliminada, mas tão somente escamoteada sob a cortina de fumaça dos limites imanentes, pois nada tem de mecânica a tarefa de definir os contornos de cada norma constitucional, levando em consideração todas as demais que compõem o sistema. E a estrutura da argumentação jurídica empregada para a definição destes limites não contém elementos para afastar ou constranger a discricionariedade judicial, como aqueles que foram desenvolvidos ao longo do tempo no campo da ponderação (...). ${ }^{167}$
\end{abstract}

Ademais, os críticos da teoria interna afirmam que ela nega a existência de uma tensão entre interesses conflitantes ou direitos concorrentes em todas as decisões sobre a prevalência de um trunfo. ${ }^{168} \mathrm{O}$ teórico interno, para isso, intenta demonstrar "que o conflito ou concorrência é apenas aparente, e que a exceção defendida é, de fato, um caso de nãoaplicabilidade, desde o início, do trunfo em questão". ${ }^{169}$ Portanto, tal ideia implica que "(...) o conteúdo do direito e as condições para sua restrição estão misturados". ${ }^{170}$

De acordo com a doutrina de Jorge Reis Novais, não obstante careça do oferecimento de uma forma racional e transparente de controlar a (in)constitucionalidade dos limites impostos a certos direitos fundamentais, a teoria interna apresenta uma delimitação bastante rígida, "apriorística" ou ultrarrestritiva dos direitos fundamentais, que elimina semântica e conceitualmente os conflitos entre direitos. ${ }^{171}$

\footnotetext{
${ }^{165}$ SOUZA NETO, Cláudio Pereira de; SARMENTO, Daniel. Direito Constitucional: Teoria, história e métodos de trabalho. 2. ed. Belo Horizonte: Fórum, 2014, p. 501.

${ }^{166}$ Cf. SOUZA NETO, Cláudio Pereira de; SARMENTO, Daniel. Direito Constitucional: Teoria, história e métodos de trabalho. 2. ed. Belo Horizonte: Fórum, 2014, p. 500; PEREIRA, Jane Reis Gonçalves. Interpretação constitucional e direitos fundamentais. Rio de Janeiro: Renovar, 2006, p. 174-182.

${ }^{167}$ SOUZA NETO, Cláudio Pereira de; SARMENTO, Daniel. Direito Constitucional: Teoria, história e métodos de trabalho. 2. ed. Belo Horizonte: Fórum, 2014, p. 500-501.

${ }^{168}$ COSTA NETO, João. Entre Cila e Caríbdis: a liberdade de expressão em meio ao conflito entre a discricionariedade do Legislador e a intensidade do controle exercido pelo Juiz Constitucional. São Paulo: Saraiva, no prelo.

${ }^{169}$ COSTA NETO, João. Entre Cila e Caríbdis: a liberdade de expressão em meio ao conflito entre a discricionariedade do Legislador e a intensidade do controle exercido pelo Juiz Constitucional, no prelo.

${ }^{170}$ KLATT, Matthias; MEISTER, Moritz. The Constitutional Structure of Proportionality. Oxford: Oxford University Press, 2012, p. 21.

${ }^{171}$ REIS NOVAIS, Jorge. Direitos Fundamentais e Justiça Constitucional em Estado de Direito Democrático. Coimbra: Coimbra Editora, 2012, p. 31 apud COSTA NETO, João. Entre Cila e Caríbdis: a liberdade de
} 
Ao constatar a persistência do problema prático sobre onde termina a abrangência de um direito, o Professor João Costa Neto comenta que, "na teoria interna, essa questão é respondida a partir de um ponto de vista conceitual, concernente à própria definição do direito". E, acrescenta, ainda, que, "na teoria externa, o conflito não é velado ou escondido, pois é resolvido através do sopesamento". ${ }^{172}$ Ademais, explica o aludido autor que, devido ao caráter holístico inerente à teoria interna, esta pode levar-nos à impressão de que:

(...) todos os direitos e interesses assegurados por determinado sistema jurídico estão em perfeita harmonia, uma vez que não pode haver qualquer sobreposição entre as áreas de proteção de quaisquer direitos ou trunfos. ${ }^{173}$

Para Aharon Barak, "a abrangência dos direitos fundamentais é determinada de acordo com sua interpretação”. Assim, limitações “(...) são parte dos direitos fundamentais. Elas não os limitam. Ao invés disso, determinam seu conteúdo de acordo com a perspectiva da comunidade em determinada época". ${ }^{174}$

Não obstante, Jorge Reis Novais sugere o que ele considera uma melhor solução: as construções capazes de evidenciar, da forma mais transparente possível, os conflitos de interesses, de valores e "princípios que subjazem a todos os casos difíceis de direitos fundamentais". ${ }^{175} \mathrm{O}$ que nos propõe o referido autor é a observância de que, ao resolver conflitos, tornar-se-ia possível controlar determinada solução de forma intersubjetivamente partilhada, no lugar de se ocultar semanticamente ou de neutralizar teoreticamente os tipos de conflitos entre direitos fundamentais que frequentemente constituem os chamados casos difíceis ou hard cases. ${ }^{176}$

Aharon Barak assevera que a redução do conflito entre direitos fundamentais acarreta um “(...) resultado interpretativo que deixa alguns aspectos da penumbra do direito fora de seu âmbito de proteção reconhecido". ${ }^{177}$

expressão em meio ao conflito entre a discricionariedade do Legislador e a intensidade do controle exercido pelo Juiz Constitucional, 2014, p. 152.

${ }^{172}$ COSTA NETO, João. Entre Cila e Caríbdis: a liberdade de expressão em meio ao conflito entre a discricionariedade do Legislador e a intensidade do controle exercido pelo Juiz Constitucional. São Paulo: Saraiva, no prelo.

${ }^{173}$ COSTA NETO, João. Entre Cila e Caríbdis: a liberdade de expressão em meio ao conflito entre a discricionariedade do Legislador e a intensidade do controle exercido pelo Juiz Constitucional. São Paulo: Saraiva, no prelo.

${ }^{174}$ BARAK, Aharon. Proportionality: Constitutional Rights and their Limitations. Cambridge: Cambridge University Press, 2012, p. 493.

${ }^{175}$ REIS NOVAIS, Jorge. Direitos Fundamentais e Justiça Constitucional em Estado de Direito Democrático. Coimbra: Coimbra Editora, 2012. p. 31 e ss.

${ }^{176}$ REIS NOVAIS, Jorge. Direitos Fundamentais e Justiça Constitucional em Estado de Direito Democrático. Coimbra: Coimbra Editora, 2012. p. 31 e ss.

177 BARAK, Aharon. Proportionality: Constitutional Rights and their Limitations. Cambridge: Cambridge University Press, 2012, p. 514. 
Daniel Sarmento e Cláudio Pereira Neto direcionam também suas objeções à teoria do juízo de adequação adotada por Habermas e Günther. Aqueles apontam que a referida teoria embora critique o arbítrio judicial, não oferece elementos consistentes para eliminá-lo. Sabemos que a partir do momento em que é permitido ao magistrado realizar juízos particularistas, é dizer, juízos que considerem as circunstâncias particulares ao caso concreto, como é o caso da ponderação, abre-se a possibilidade de se criticar a questão da discricionariedade judicial. Afinal de contas, a ponderação permite maior espaço para a atividade criativa do intérprete. No entanto, e, apesar de ser persuasiva em suas alegações, a teoria do juízo de adequação “incorre em uma inegável contradição performática”. É o que apontam os seus críticos da teoria, segundo os quais:

\begin{abstract}
(...) a alternativa que sugere é um procedimento ainda mais aberto e opaco, não provendo critérios consistentes ou parâmetros controláveis para se definir qual, afinal, é a norma adequada. A ponderação conta, por outro lado, com os critérios do princípio da proporcionalidade para domesticar o decisionismo e gerar alguma previsibilidade. A teoria da adequação, para ser coerente com a critica que formula à ponderação, deveria fornecer um método seguro e previsível, o que não ocorre. ${ }^{178}$
\end{abstract}

Acrescentam os referidos autores que, assim como o que ocorre com a teoria do juízo de adequação, a teoria formulada por Ronald Dworkin também não oferece solução para o risco do arbítrio nacional, mas, ao contrário, ela reconhece que a tarefa de definição dos limites das normas constitucionais e dos direitos fundamentais é dotada de tamanha complexidade que poderia somente ser levada a termo, em especial nos casos constitucionais difíceis, "por juízes idealizados, concebidos contrafaticamente como semideuses ('o juiz Hércules'), que seriam forçados a tornarem-se verdadeiros filósofos, como árbitros finais dos conflitos morais que dividem às sociedades". ${ }^{179}$

Nesse sentido, Robert Alexy ${ }^{180}$ nega que Dworkin tenha a expectativa de que os juízes reais sejam como Hércules. Pelo contrário, o conceito de juiz hercúleo enquanto aquele dotado de onisciência, de habilidades ideais e de todas as informações necessárias para conhecer todos os princípios, possuindo uma visão completa do conjunto do Direito vigente e, portanto, integral, "é uma construção contrafática proposta no contexto de formulação da tese

\footnotetext{
${ }^{178}$ SOUZA NETO, Cláudio Pereira de; SARMENTO, Daniel. Direito Constitucional: Teoria, história e métodos de trabalho. 2. ed. Belo Horizonte: Fórum, 2014, p. 500-501.

${ }^{179}$ SOUZA NETO, Cláudio Pereira de; SARMENTO, Daniel. Direito Constitucional: Teoria, história e métodos de trabalho. 2. ed. Belo Horizonte: Fórum, 2014, p. 501-502.

${ }^{180}$ ALEXY, Robert. Sistema jurídico, principios jurídicos y razón práctica. In: ALEXY, Robert. Derecho y razón práctica.Traducción de Manuel Atienza. México: Fontamara, 1993, p. 10.
} 
da única resposta correta". ${ }^{181}$ Nesse ínterim, Alexy conclui que a tese defendida por Dworkin de que existe uma única resposta correta para todas as controvérsias jurídicas é, na verdade, inalcançável, na prática. Seria, portanto, alcançada por magistrados ideais, como Hércules. ${ }^{182}$

Carlos Bernal Pulido, por derradeiro, assevera que a teoria interna percorre o intento de conferir objetividade à interpretação dos direitos fundamentais a partir de "reconstruções conceituais fatigadas por consideráveis problemas de racionalidade teórica" "183. Igualmente, ela não faz frente aos problemas reais esboçados pela argumentação "jusfundamental" dos casos difíceis, escondidos pelo manto de um "exagerado cognoscitivismo que se resolve em pura subjetividade do intérprete". Dá-se lugar, assim, a um “déficit de fundamentación” das decisões jurisprudenciais e, com isso, ao exercício de um poder discricionário não submetido a fiscalização alguma. ${ }^{184}$

Finalmente, podemos chegar a uma posição conclusiva: uma vez mais, deparamo-nos com a crença em um método heurístico que pretende conferir segurança, mas que não consegue. Os autores supracitados revelam-se envoltos pelo apego ao método e sua falsa garantia de defesa de direitos.

A despeito da gama de críticas, em momento posterior deste estudo (Parte III), mostraremos que essa impressão que conduz muitos dos críticos de Dworkin, de que todos os direitos e interesses assegurados por determinado sistema jurídico estão em perfeita harmonia, devido à existência de trunfos, resta equivocada. A ideia de integridade em Dworkin não anula a aceitabilidade de que direitos entrem em rota de colisão. A integridade será lida como o caminho coerente a se perquirir, onde o intérprete utilizar-se-á da diferenciação de argumentos de princípio dos argumentos de política, por exemplo, rumo a um juízo interpretativo de cada caso concreto.

\subsection{TEORIA EXTERNA DOS LIMITES DOS DIREITOS FUNDAMENTAIS}

\subsubsection{Considerações gerais}

\footnotetext{
${ }^{181}$ SOUZA NETO, Cláudio Pereira de; SARMENTO, Daniel. Direito Constitucional: Teoria, história e métodos de trabalho. 2. ed. Belo Horizonte: Fórum, 2014, p. 502.

${ }^{182}$ ALEXY, Robert. Sistema jurídico, principios jurídicos y razón práctica. In: ALEXY, Robert. Derecho y razón práctica.Traducción de Manuel Atienza. México: Fontamara, 1993, p. 10.

${ }^{183}$ LOPERA MESA, Gloria-Patricia. El principio de proporcionalidad y los dilemas del constitucionalismo. Comentario al libro de CARLOS BERNAL PULIDO: El principio de proporcionalidad y los derechos fundamentales. Tradução livre. Madrid, Centro de Estudios Políticos y Constitucionales, 2003. In: Revista Española de Derecho Constitucional, Nueva Época, ISSN: 0211-5743, n. 73, enero-abril (2005), p. 389.

${ }^{184}$ PULIDO, Carlos Bernal. El principio de proporcionalidad y los derechos fundamentales. Madrid: Centro de Estudios Políticos y Constitucionales, 2003, p. 471.
} 
Também denominada concepção ampla, de acordo com Medina Guerreiro ${ }^{185}$, essa teoria sustenta que a identificação do âmbito de proteção de um direito fundamental exige duas fases de raciocínio. O conteúdo protegido de um direito fundamental é identificado inicialmente, mas não de forma definitiva. Aqui, diferentemente do que ocorre na teoria interna, o âmbito de proteção do direito fundamental é bem amplo.

Ao discorrer sobre o âmbito de proteção do direito fundamental sob a ótica da teoria externa, a doutrina de Pedro Serna e Fernando Toller elucida que esse âmbito de proteção abrange:

\begin{abstract}
(...) as faculdades que genericamente se conectam com o interesse individual protegido pelo direito, entendidas com a maior extensão possível, sem prender-se em comprovar se podem danificar ou afetar algum direito dos demais ou interesse comunitários. ${ }^{186}$
\end{abstract}

Posteriormente, diante da necessidade de harmonizar o conteúdo do direito fundamental identificado prima facie com os demais direitos fundamentais e bens constitucionalmente protegidos, chegar-se-á, então, ao conteúdo definitivo do direito fundamental: a identificação das situações que podem considerar-se definitivamente amparadas por um direito fundamental. ${ }^{187}$ Portanto, somente após chegar-se à segunda fase é que se pode afirmar que o conteúdo do direito fundamental inicialmente verificado pode ser restringido por fatores externos a ele.

Ressalte-se, dessa forma, um ponto crucial para a diferenciação entre a teoria externa e a interna: para esta, a conformação de determinado direito fundamental com todos os demais não representa uma limitação externa ao direito fundamental, mas uma delimitação prévia da extensão do âmbito de proteção dos direitos fundamentais tecida pela própria Constituição, tratando-se dos limites imanentes aos direitos fundamentais. Nesse sentido, Mariano Bacigalupo questiona: "os limites imanentes delimitam a extensão do âmbito de proteção do direito fundamental ou constituem tais limites uma verdadeira limitação do direito?". ${ }^{188}$

De acordo com a teoria externa dos limites dos direitos fundamentais, quando se está frente a determinado caso concreto, o direito fundamental existe prima facie, mas por algum

\footnotetext{
${ }^{185}$ MEDINA GUERREIRO, Manuel. La vinculación negativa del legislador a los derechos fundamentales. Madrid: Ciencias Jurídicas, 1996, p. 91 e ss.

${ }^{186}$ SERNA, Pedro; TOLLER, Fernando. La Interpretación Constitucional de Los Derechos Fundamentales. Una alternativa a los Conflictos de Derechos. Buenos Aires: La Ley, 200, p. 20.

${ }^{187}$ Cf. BOROWSKI, Martin. La restricción de los derechos fundamentales. In: Revista Española de Derecho Constitucional, Madrid, a. 20, n. 59, mayo/ago., 2000, p. 31.

${ }^{188}$ BACIGALUPO, Mariano. La aplicación de la doctrina de los "límites inmanentes" a los derechos fundamentales sometidos a reserva de limitación legal (A propósito de la sentencia del Tribunal Administrativo Federal alemán de 18 de octubre de 1990).In: Revista Española de Derecho Constitucional, Madrid, a. 13, mayo/ago., 1993, p. 307.
} 
fator externo, como outros direitos fundamentais, a ordem pública, a moral pública, ou o bem comum, por exemplo, percebe-se a necessidade de reduzir, restringir o seu alcance. Assim, a relação entre o direito fundamental e a sua restrição nasce a partir da necessidade externa ao direito, de compatibilização de direitos - individuais e coletivos. ${ }^{189}$

Diante das supostas deficiências apresentadas pela teoria interna dos direitos fundamentais, Carlos Bernal ${ }^{190}$ defende a superioridade da teoria externa - também por ele chamada teoría del contenido amplio de los derechos fundamentales -, baseada na distinção entre um âmbito inicial de proteção prima facie e um âmbito de proteção definitiva. Trata-se das duas fases aqui supramencionadas. Tal distinção é obtida a partir do estabelecimento de uma relação, primeiramente, com as demais normas do sistema e, posteriormente, da resolução das colisões que emergem ao se determinar o conteúdo do direito frente a cada caso concreto.

Defende, ainda, o referido autor, que é sobre essa concepção que se apoia o princípio da proporcionalidade, uma vez que ela oferece "(...) una mejor aproximación teórica a la compleja estructura normativa de los derechos fundamentales y vincula la determinación de su contenido a una argumentación mucho más depurada y exigente (...)”, o que permite a demarcação visível da margem de discricionariedade da qual dispõe o juiz constitucional. ${ }^{191}$

Também defende a superioridade da teoria externa o Professor João Costa Neto, segundo o qual ela é superior à teoria interna uma vez que logra separar claramente o estágio em que um direito é definido daquele em que suas limitações são justificadas. Assim, “(...) os direitos de outros e os interesses públicos relevantes só são considerados na fase de justificação". ${ }^{192}$

Para a teoria externa, qualquer restrição a um direito fundamental é uma restrição externa a esse direito. Para que essa restrição venha a ser admitida pelo ordenamento jurídico, ela deve encontrar conciliação com o conjunto de garantias previstas pela Constituição garantias próprias de um estado de direito, para qualquer atividade limitadora de um direito fundamental. Desse modo, a lei que restringe o direito fundamental deverá ser genérica, além

\footnotetext{
${ }^{189}$ ALEXY, Robert. Teoria dos Direitos Fundamentais, 2. ed., Tradução de Virgílio Afonso da Silva da $5^{\mathrm{a}}$ edição alemã Theorie der Grundrechte. São Paulo: Malheiros Editores, 2009, p. 276 e ss.

${ }^{190}$ PULIDO, Carlos Bernal. El principio de proporcionalidad y los derechos fundamentales. Madrid: Centro de Estudios Políticos y Constitucionales, 2003, p. 458 e ss.

${ }^{191}$ PULIDO, Carlos Bernal. El principio de proporcionalidad y los derechos fundamentales. Madrid: Centro de Estudios Políticos y Constitucionales, 2003, p. 458 e ss.

${ }^{192}$ COSTA NETO, João. Entre Cila e Caríbdis: a liberdade de expressão em meio ao conflito entre a discricionariedade do Legislador e a intensidade do controle exercido pelo Juiz Constitucional. São Paulo: Saraiva, no prelo.
} 
de submeter-se à observância do princípio da proporcionalidade. ${ }^{193}$ A autorização constitucional, por derradeiro, clamará pelo respeito ao conteúdo essencial do direito fundamental restringido.

Acrescente-se que a teoria externa assinala o princípio da proporcionalidade como critério capaz de definir o conteúdo definitivo dos direitos fundamentais nos casos concretos. Esse entendimento é de larga escala entre as jurisprudências constitucionais, destacando-se sua adoção pelas doutrinas de Robert Alexy ${ }^{194}$ e M. Borowski ${ }^{195}$ na Alemanha, Manuel Medina Guerrero ${ }^{196}$, Carlos Bernal ${ }^{197}$ e Joaquín Camazano ${ }^{198}$ na Espanha, e Pedro Serna e Fernando Toller ${ }^{199}$ na Argentina, por exemplo.

Joachim Zekoll e Mathias Reimann ${ }^{200}$ indicam que, na Alemanha, possui força de predominância o entendimento de que os direitos fundamentais estão sujeitos à limitação em determinadas circunstâncias e que tais limitações são governadas pelo princípio da proporcionalidade, que, por sua vez, exige que qualquer interferência nos direitos fundamentais seja apropriada, necessária e razoável, ou seja, proporcional em sentido estrito.

Ao analisar as decisões constitucionais hispânicas, Pedro Serna e Fernando Toller asseveram:

\begin{abstract}
(...) ao menos no caso espanhol, e a nosso ver, só há limites externos ao direito fundamental. Não existem, sinceramente, limites imanentes (em sentido estrito), categoria que deve por isso rechaçar-se a si mesma. (...) Basta agora aqui deixar apontada esta ideia geral, que tem inválida a classificação que distingue entre limites imanentes (estritos) e limites externos, salvo na medida em que ela resulta útil para excluir toda possível existência dos primeiros. ${ }^{201}$
\end{abstract}

Ao tecer estudos sobre o princípio da proporcionalidade, Carlos Bernal relaciona o esclarecimento conceitual desse princípio com outras figuras dogmáticas que intervêm na fundamentação externa da premissa maior do juízo de constitucionalidade, tais como os

\footnotetext{
${ }^{193}$ SERNA, Pedro; TOLLER, Fernando. La Interpretación Constitucional de Los Derechos Fundamentales. Una alternativa a los Conflictos de Derechos. Buenos Aires: La Ley, 200, p. 19.

${ }^{194}$ Cf. ALEXY, Robert. Teoria dos Direitos Fundamentais, 2. ed., Tradução de Virgílio Afonso da Silva da $5^{\text {a }}$ edição alemã Theorie der Grundrechte. São Paulo: Malheiros Editores, 2009, p. 276 e ss.

${ }^{195}$ Cf. BOROWSKI, Martin. La restricción de los derechos fundamentales. In: Revista Española de Derecho Constitucional, Madrid, a. 20, n. 59, mayo/ago., 2000, p. 56 e ss.

${ }^{196}$ Cf. MEDINA GUERRERO, Manuel. La vinculación negativa del legislador a los derechos fundamentales. Madrid: Ciencias Jurídicas, 1996, p. 91 e ss.

${ }^{197}$ Cf. PULIDO, Carlos Bernal. El principio de proporcionalidad y los derechos fundamentales. Madrid: Centro de Estudios Políticos y Constitucionales, 2003, p. 458 e ss.

${ }^{198}$ Cf. CAMAZANO, Joaquín Brage. Los Límites a los Derechos Fundamentales. Madrid: Dylinson, 2004, p. 256.

${ }^{199}$ Cf. SERNA, Pedro; TOLLER, Fernando. La Interpretación Constitucional de Los Derechos Fundamentales. Una alternativa a los Conflictos de Derechos. Buenos Aires: La Ley, 200, p.87 e ss.

${ }^{200}$ ZEKOLL, Joaquim; REIMANN, Mathias. Introduction to German Law. 2nd ed. Washington: Kluwer Law International, 2005, p. 76.

${ }^{201}$ SERNA, Pedro; TOLLER, Fernando. La Interpretación Constitucional de Los Derechos Fundamentales. Una alternativa a los Conflictos de Derechos. Buenos Aires: La Ley, 200, p.87 e ss.
} 
cânones tradicionais da interpretação jurídica, os critérios específicos da interpretação constitucional, o método da ponderação, bem como a noção de conteúdo essencial. ${ }^{202} \mathrm{O}$ autor propõe-se a desenvolver uma reinterpretação deste último conceito - contenido esencial -, com o intento de conferir à cláusula prevista no artigo 53.1 da Constituição Espanhola ${ }^{203}$ um significado que permita torná-la operacionalmente possível e compatível com o princípio da proporcionalidade.

Nesse sentido, Bernal estipula que o conteúdo essencial estaria integrado "por todas las normas y posiciones definitivas que pueden adscribirse a una disposición iusfundamental". Nos casos fáceis essa atribuição pode dar-se sem ajuda do princípio da proporcionalidade, de forma que nessas situações a garantia do conteúdo essencial opera de modo independente do referido princípio. No entanto, isso não ocorre nos chamados casos difíceis, onde a determinação do conteúdo definitivo dos direitos, é dizer, do conteúdo essencial, é resultado da aplicação do princípio da proporcionalidade. ${ }^{204}$

No Brasil, pode-se dizer que a teoria externa é majoritariamente acolhida pela doutrina e jurisprudência, fixando-se a ponderação de princípios como forma capaz de direcionar o intérprete diante da solução de conflitos entre direitos fundamentais.

Pois bem, vale tecer algumas considerações acerca do que, para nós, consiste em um problema da teoria externa. O problema central é que ela concebe os direitos como, a princípio, ilimitados, dependendo de atos externos legislativos ou judiciais para lhes emprestar limites, de forma constitutiva. A partir dessa constatação, vale apontar: "Ora, mesmo no silêncio do texto qualquer direito, inclusive os clássicos direitos individuais, só pode ser compreendido adequadamente como parte de um ordenamento complexo". 205

\footnotetext{
${ }^{202}$ PULIDO, Carlos Bernal. El principio de proporcionalidad y los derechos fundamentales. Madrid: Centro de Estudios Políticos y Constitucionales, 2003, p. 560 e ss.

${ }^{203}$ Cf. LA CONSTITUCIÓN ESPAÑOLA DE 1978. Título I. De los derechos y deberes fundamentales. Capítulo cuarto. De las garantías de las libertades y derechos fundamentales. Artículo 53: "Los derechos y libertades reconocidos en el Capítulo segundo del presente Título vinculan a todos los poderes públicos. Sólo por ley, que en todo caso deberá respetar su contenido esencial, podrá regularse el ejercicio de tales derechos y libertades, que se tutelarán de acuerdo con lo previsto en el artículo 161, 1, a).”

${ }^{204}$ PULIDO, Carlos Bernal. El principio de proporcionalidad y los derechos fundamentales. Madrid: Centro de Estudios Políticos y Constitucionales, 2003, p. 560 e ss.

${ }^{205}$ CARVALHO NETTO, Menelick de; SCOTTI, Guilherme. Os Direitos Fundamentais e a (in)certeza do Direito: a produtividade das tensões principiológicas e a superação do sistema de regras. Belo Horizonte: Editora Fórum, 2011, p. 55 e ss.
} 
A nossa vivência geracional permite-nos enxergar "a possibilidade de que pretensões abusivas em relação a direitos genérica e abstratamente prefigurados em lei tendam a ser levantadas nos casos concretos, na vida cotidiana". ${ }^{206}$

O problema do Direito moderno não é solucionado pela edição de normas, pelo contrário, precisamos ir mais além, depara-se com o desafio da aplicação adequada de normas gerais e abstratas a situações de vida sempre individualizadas e concretas, à situação de aplicação, sempre única e irrepetível, por definição. ${ }^{207} \mathrm{O}$ presente cenário é enriquecido pela complexidade do conjunto de normas gerais e abstratas. A complexidade, por sua vez,

(...) envolve uma faceta que não mais pode se confundir com o exercício legítimo de direitos, a das pretensões abusivas que a mera edição em texto do direito na forma de norma geral e abstrata incentiva. E isso porque ela (a norma) pode e tende a ser enfocada também da perspectiva de um mero observador interessado em sempre levar vantagem, o que vem ressaltar um aspecto central que hoje reveste os direitos fundamentais enquanto princípios constitucionais fundantes de uma comunidade de pessoas que se reconhecem como reciprocamente merecedoras de igual respeito e consideração em todas as situações de vida concreta em que se encontrem e que Konrad Hesse denominou a "força irradiadora dos princípios". ${ }^{208}$

${ }^{206}$ CARVALHO NETTO, Menelick de; SCOTTI, Guilherme. Os Direitos Fundamentais e a (in)certeza do Direito: a produtividade das tensões principiológicas e a superação do sistema de regras. Belo Horizonte: Editora Fórum, 2011, p. 55 e ss.

${ }^{207}$ CARVALHO NETTO, Menelick de; SCOTTI, Guilherme. Os Direitos Fundamentais e a (in)certeza do Direito: a produtividade das tensões principiológicas e a superação do sistema de regras. Belo Horizonte: Editora Fórum, 2011, p. 55 e ss.

${ }^{208}$ CARVALHO NETTO, Menelick de; SCOTTI, Guilherme. Os Direitos Fundamentais e a (in)certeza do Direito: a produtividade das tensões principiológicas e a superação do sistema de regras. Belo Horizonte: Editora Fórum, 2011, p. 55 e ss. 


\section{PARTE II - O DIREITO COMO MÉTODO EM ALEXY VERSUS O DIREITO PRINCIPIOLÓGICO EM DWORKIN}

\section{ALEXY: O DIREITO COMO MÉTODO}

\subsection{PRINCÍPIOS ABSOLUTOS E A LEI DE COLISÃO}

Ao analisar a designação "princípios absolutos" enquanto princípios extremamente fortes que, em nenhuma hipótese, cedem em favor de outros, Robert Alexy ressalta que se existem princípios desse tipo, então a definição de princípios deve ser modificada. Isso porque, "se um princípio tem precedência em relação a todos os outros em casos de colisão, até mesmo em relação ao princípio que estabelece que as regras devem ser seguidas, nesse caso, isso significa que sua realização não conhece nenhum limite jurídico" ${ }^{\text {209 }}$, mas apenas limites fáticos. A absolutização de princípios, já aprofundada neste trabalho ${ }^{210}$, torna inaplicável a chamada "lei de colisão", defendida pela doutrina alexiana.

Vale relembrar que a "lei de colisão" consiste em um dos fundamentos da teoria dos princípios defendida por Alexy. "Ela reflete a natureza dos princípios como mandamentos de otimização: em primeiro lugar, a inexistência de relação absoluta de precedência e, em segundo lugar, sua referência a ações e situações que não são quantificáveis". ${ }^{211}$ Ressalte-se que, ao estabelecer relações concretas de precedência, a lei de colisão possibilita uma dogmática diferenciada dos direitos fundamentais específicos, de modo a negar preferências e cedências generalizantes. De acordo com essa lei, "o estabelecimento de uma restrição não é uma questão tudo-ou-nada, mas um problema de 'afastamento do direito fundamental em relações individuais, ", 212

\subsection{A DIGNIDADE HUMANA EM ALEXY E SUAS DUAS NORMAS: A REGRA ABSOLUTA E O PRINCÍPIO SOPESÁVEL}

Diante do art. $1^{\circ}, \S 1^{\circ}, 1$ da Lei Fundamental alemã, segundo o qual "a dignidade humana é inviolável"213, quedamo-nos instigados à impressão de um caráter absoluto

\footnotetext{
${ }^{209}$ ALEXY, Robert. Teoria dos Direitos Fundamentais, 2. ed., Tradução de Virgílio Afonso da Silva da $5^{\text {a }}$ edição alemã Theorie der Grundrechte. São Paulo: Malheiros Editores, 2009, p. 111.

${ }^{210}$ Cf. Parte I, ítem 3.1.

${ }^{211}$ ALEXY, Robert. Teoria dos Direitos Fundamentais, 2. ed., Tradução de Virgílio Afonso da Silva da $5^{\text {a }}$ edição alemã Theorie der Grundrechte. São Paulo: Malheiros Editores, 2009, p. 99.

212 ALEXY, Robert. Teoria dos Direitos Fundamentais, 2. ed., Tradução de Virgílio Afonso da Silva da $5^{\text {a }}$ edição alemã Theorie der Grundrechte. São Paulo: Malheiros Editores, 2009, p. 99, Cf. BVerfGE 28, 243 (263).

${ }^{213}$ DEUTSCHER BUNDESTAG. Lei Fundamental da República Federal da Alemanha. Disponível em: < https://www.btg-bestellservice.de/pdf/80208000.pdf> . Acesso em 5 out. 2015.
} 
possivelmente conferido à dignidade humana. No entanto, para Alexy, o motivo para essa impressão reside no fato de a norma da dignidade humana ser tratada em parte como regra, e em parte como princípio e, também, no fato de existir, quando se trata da dignidade, "um amplo grupo de condições de precedência que conferem altíssimo grau de certeza de que, sob essas condições, o princípio da dignidade humana prevalecerá contra os princípios colidentes". ${ }^{214}$

Nesse sentido, a natureza de regra da dignidade humana seria percebida, nos casos em que a norma da dignidade humana é relevante, mediante a constatação do não questionamento se ela prevalece sobre outras normas, mas tão somente se ela foi violada, ou não. Contudo, a tecitura aberta inerente à referida norma permite uma ampla margem de sua apreciação. Diante de uma consideração do Tribunal Constitucional Federal alemão ${ }^{215}$, mais precisamente, em uma decisão acerca da interceptação telefônica, tem-se:

No que diz respeito ao princípio da inviolabilidade da dignidade humana, disposto no art. $1^{\circ}$ da Constituição alemã (...), tudo depende da definição das circunstâncias nas quais a dignidade humana pode ser considerada como violada. Com certeza, não há uma resposta geral, devendo-se sempre levar em consideração o caso concreto. ${ }^{216}$

Destarte, a partir da fórmula do "tratamento degradante" 217 , utilizada na decisão, o Tribunal permite-se a possibilidade de se recorrer ao sopesamento, abrindo ampla margem de apreciação para tal definição diante de casos concretos. Tal possibilidade é percebida em manifestações do Tribunal como aquela segundo a qual a dignidade humana não é violada no caso de a exclusão da proteção judicial não for motivada por uma desconsideração ou uma depreciação da pessoa humana, mas por uma necessidade de se manter em segredo as medidas que sirvam o a proteção da ordem democrática e para a própria existência do Estado. ${ }^{218}$ Com isso, Alexy compreende ser possível que o princípio da proteção do Estado tenha precedência em face do princípio da dignidade humana - no que concerne à exclusão da proteção judicial em casos de escuta telefônica, por exemplo - quando a manutenção do segredo for necessária e outras condições, como o controle jurídico por órgãos de representação popular, por

\footnotetext{
${ }^{214}$ ALEXY, Robert. Teoria dos Direitos Fundamentais, 2. ed., Tradução de Virgílio Afonso da Silva da $5^{\text {a }}$ edição alemã Theorie der Grundrechte. São Paulo: Malheiros Editores, 2009, p. 111-112. ${ }^{215}$ BVerfGE 30,1 (25).

${ }^{216}$ ALEXY, Robert. Teoria dos Direitos Fundamentais, 2. ed., Tradução de Virgílio Afonso da Silva da $5^{\text {a }}$ edição alemã Theorie der Grundrechte. São Paulo: Malheiros Editores, 2009, p. 112 Cf. BVerfGE 30,1 (25). 217 ALEXY, Robert. Teoria dos Direitos Fundamentais, 2. ed., Tradução de Virgílio Afonso da Silva da $5^{\mathrm{a}}$ edição alemã Theorie der Grundrechte. São Paulo: Malheiros Editores, 2009, p. 112-113 Cf. BVerfGE 30,1 (26). ${ }_{218}$ ALEXY, Robert. Teoria dos Direitos Fundamentais, 2. ed., Tradução de Virgílio Afonso da Silva da $5^{\text {a }}$ edição alemã Theorie der Grundrechte. São Paulo: Malheiros Editores, 2009, p. 112-113 Cf. BVerfGE 30,1 (27).
} 
exemplo, forem satisfeitas. ${ }^{219}$ Caso as referidas condições desaparecessem, a medida a ser julgada não seria mais permitida, constatação essa que demonstra a contraposição entre razões e contrarrazões. Aqui, o princípio da dignidade humana prevaleceria sobre o princípio da proteção do Estado. Conforme suas palavras, Alexy assevera que "isso pode ser generalizado: se no nível dos princípios a dignidade tem precedência, então, ela foi violada no nível das regras.",220

Desse modo, Alexy defende o sopesamento do princípio da dignidade humana perante outros princípios, para que se possa determinar o conteúdo da regra da dignidade humana. ${ }^{221}$ Percebemos esse entendimento, com particular clareza, refletido na decisão do Tribunal Constitucional Federal alemão acerca da prisão perpétua, onde se afirma que "a dignidade humana (...) tampouco é violada se a execução da pena for necessária em razão da permanente periculosidade do preso e se, por essa razão, for vedada a graça". ${ }^{222}$ Essa decisão será posteriormente abordada no presente trabalho, quando tratarmos da garantia do núcleo essencial dos direitos fundamentais. Nesse ínterim, o Tribunal posicionou-se pela compatibilidade da pena perpétua por homicídio qualificado diante da Lei Fundamental alemã, de modo que a pena perpétua não afronta o núcleo essencial da dignidade humana, desde que observada a possibilidade factível de o bom comportamento do preso vir a libertálo. A partir dessa formulação, preenchidas as devidas condições, tem-se que a proteção da "comunidade estatal", no caso em comento, tem precedência em face do princípio da dignidade humana. Diante de outras condições, ressalte-se que a precedência poderá ser estabelecida de outra forma. ${ }^{223}$

Com isso, Alexy destaca a necessidade do estabelecimento de duas normas da dignidade humana: "uma regra da dignidade humana e um princípio da dignidade humana". A partir da relação de preferência do princípio da dignidade humana em face de outros princípios, temos a determinação do conteúdo da regra da dignidade humana. Note-se que “(...) não é o princípio que é absoluto, mas a regra, a qual, em razão de sua abertura semântica, não necessita de limitação em face de alguma possível relação de preferência". ${ }^{224}$

\footnotetext{
${ }^{219}$ ALEXY, Robert. Teoria dos Direitos Fundamentais, 2. ed., Tradução de Virgílio Afonso da Silva da $5^{\text {a }}$ edição alemã Theorie der Grundrechte. São Paulo: Malheiros Editores, 2009, p. 112-113.

${ }^{220}$ ALEXY, Robert. Teoria dos Direitos Fundamentais, 2. ed., Tradução de Virgílio Afonso da Silva da $5^{\text {a }}$ edição alemã Theorie der Grundrechte. São Paulo: Malheiros Editores, 2009, p. 113.

221 ALEXY, Robert. Teoria dos Direitos Fundamentais, 2. ed., Tradução de Virgílio Afonso da Silva da $5^{\mathrm{a}}$ edição alemã Theorie der Grundrechte. São Paulo: Malheiros Editores, 2009, p. 113.

${ }^{222}$ BVerfGE 45, 187 (242).

${ }^{223}$ Cf. ALEXY, Robert. Teoria dos Direitos Fundamentais, 2. ed., Tradução de Virgílio Afonso da Silva da $5^{\mathrm{a}}$ edição alemã Theorie der Grundrechte. São Paulo: Malheiros Editores, 2009, p. 113.

224 ALEXY, Robert. Teoria dos Direitos Fundamentais, 2. ed., Tradução de Virgílio Afonso da Silva da $5^{\mathrm{a}}$ edição alemã Theorie der Grundrechte. São Paulo: Malheiros Editores, 2009, p. 113.
} 
Destarte, Alexy aponta tal construção como vantajosa, uma vez que, de um lado, não pressupõe a necessidade de introdução de uma cláusula restritiva ao direito fundamental à dignidade humana e, de outro, abre espaço para a possibilidade de realização de um sopesamento entre o princípio da dignidade humana e os demais princípios constitucionais.

Ao defender que o princípio da dignidade humana pode ser realizado em diferentes medidas, Alexy afirma que o fato de que, em determinadas condições, esse princípio prevaleça com maior grau de certeza sobre outros princípios não fundamenta uma natureza absoluta desse princípio. O que ocorre é que, sob determinadas condições, existem razões jurídico-constitucionais "praticamente inafastáveis para uma relação de precedência em favor da dignidade humana”. No entanto, alerta o doutrinador que a tese sobre a existência de uma posição nuclear também se aplica a outras normas de direitos fundamentais. Por conseguinte, "a norma da dignidade humana não é um princípio absoluto", sendo que a "impressão" de um caráter absoluto advém, primeiramente, da existência de duas normas da dignidade humana uma regra e um princípio. Ademais, essa impressão ganha reforço da existência de uma série de condições sob as quais o princípio da dignidade humana prevalecerá, "com grande grau de certeza", em face de todos os demais princípios. ${ }^{225}$

Dworkin $^{226}$, veremos adiante, adota uma postura completamente distinta acerca da dignidade humana: ele considera que não obstante haja a necessidade de um juízo interpretativo sensível às diferenças, é "genuinamente universal" a compreensão de que a dignidade humana, enquanto verdadeiro trunfo contra o Estado, exige preocupação e respeito iguais, além do respeito à responsabilidade pessoal, o que compõe um padrão abstrato, e não relativo, sopesável, como pressupõe Alexy.

\subsection{PRINCÍPIOS: UM CONCEITO AMPLO. DIREITOS INDIVIDUAIS E DIREITOS COLETIVOS}

Ao verificar que os princípios podem tanto se referir a direitos individuais como a direitos coletivos, Alexy ${ }^{227}$ menciona o exemplo do caso Lebach ${ }^{228}$, julgado pelo Tribunal Constitucional Federal alemão, que, por sua vez, verificou a existência de dois princípios contrapostos, sendo um garantidor de um direito prima facie à proteção da personalidade, e o

\footnotetext{
${ }^{225}$ ALEXY, Robert. Teoria dos Direitos Fundamentais, 2. ed., Tradução de Virgílio Afonso da Silva da $5^{\mathrm{a}}$ edição alemã Theorie der Grundrechte. São Paulo: Malheiros Editores, 2009, p. 114.

${ }^{226}$ DWORKIN, Ronald. A raposa e o porco-espinho: justiça e valor. Tradução de Marcelo Brandão Cipolla. São Paulo: Editora WMF Martins Fontes, 2014, p. 507-517.

${ }^{227}$ ALEXY, Robert. Teoria dos Direitos Fundamentais, 2. ed., Tradução de Virgílio Afonso da Silva da $5^{\mathrm{a}}$ edição alemã Theorie der Grundrechte. São Paulo: Malheiros Editores, 2009, p. 114.

${ }^{228}$ BVerfGE 35, 202 (219).
} 
outro de um direito prima facie à liberdade de informar. Ao tecermos uma equiparação ao direito brasileiro, é possível enumerar vários exemplos de princípios vinculados a interesses coletivos, como a proteção à ordem democrática, o fornecimento de energia, o combate ao desemprego, a proteção ao consumidor, entre outros.

Devido ao fato de existirem princípios que se refiram a esses tipos de interesses coletivos, Alexy defende que esses princípios exigem a criação ou a manutenção de situações que satisfaçam, "na maior medida do possível, diante das possibilidades jurídicas e fáticas", critérios que vão além da validade ou da satisfação de direitos individuais. ${ }^{229}$

Nesse momento, Alexy realiza mais uma crítica à tese dos direitos tecida por Dworkin, sob a argumentação de que este define o conceito de princípio de forma particularmente restrita. Para Alexy, Dworkin peca quando reduz a noção de princípios apenas às normas que podem ser usadas como razões para direitos individuais, ao passo que as normas referentes a interesses coletivos são denominadas por Dworkin como "políticas". ${ }^{230}$

De fato, Dworkin realiza tal diferenciação, quando afirma serem os argumentos de princípio destinados a estabelecer um direito individual, enquanto os argumentos de política são argumentos destinados a estabelecer um objetivo coletivo. Nesse sentido, “(...) os princípios são proposições que descrevem direitos; as políticas são proposições que descrevem objetivos". ${ }^{231}$ Posteriormente, o jusfilósofo americano discorre, então, sobre a diferença entre direitos e objetivos, sendo tal compreensão um ponto-chave para a tese dos direitos dworkineana, que será mais profundamente abordada neste estudo.

Não obstante considere importante a diferenciação entre direitos individuais e interesses coletivos, Alexy assevera não ser exigível nem conveniente vincular o conceito de princípio ao conceito de direito individual, uma vez que os casos de colisões entre princípios indicam com clareza a conveniência de um "conceito amplo de princípio". 232

\subsection{A TEORIA ALEXIANA DOS PRINCÍPIOS E A MÁXIMA DA PROPORCIONALIDADE}

\footnotetext{
${ }^{229}$ ALEXY, Robert. Teoria dos Direitos Fundamentais, 2. ed., Tradução de Virgílio Afonso da Silva da $5^{\text {a }}$ edição alemã Theorie der Grundrechte. São Paulo: Malheiros Editores, 2009, p. 115.

${ }^{230}$ DWORKIN, Ronald. Taking Rights Seriously. 2.ed. London: Duckworth, 1978, pp. 82 e 90.

${ }^{231}$ DWORKIN, Ronald. Levando os direitos a sério. Tradução: Nelson Boeira, 3.ed. São Paulo: Editora WMF Martins Fontes, 2010, p. 141 e ss.

${ }^{232}$ ALEXY, Robert. Teoria dos Direitos Fundamentais, 2. ed., Tradução de Virgílio Afonso da Silva da $5^{\text {a }}$ edição alemã Theorie der Grundrechte. São Paulo: Malheiros Editores, 2009, p. 116.
} 
Não há dúvidas de que a teoria dos princípios, em Alexy, e a máxima da proporcionalidade pressupõem uma íntima e mútua relação, uma vez que “(...) a natureza dos princípios implica a máxima da proporcionalidade, e essa implica aquela”.

Tal afirmação significa que a máxima proporcionalidade é deduzível da natureza dos princípios, ou seja, a proporcionalidade, com suas três máximas parciais, a saber: a adequação, a necessidade (mandamento do meio menos gravoso) e a proporcionalidade em sentido estrito (mandamento do sopesamento propriamente dito), decorre logicamente da natureza dos princípios. ${ }^{233}$

O Tribunal Constitucional Federal alemão adotou essa noção, quando dispôs que a máxima da proporcionalidade decorre, "no fundo, já da própria essência dos direitos fundamentais". ${ }^{234}$ Com isso, Alexy intenta demonstrar que as normas de direitos fundamentais possuem o caráter de princípios.

A máxima da proporcionalidade é frequentemente denominada "princípio da proporcionalidade". Contudo, o jusfilósofo alemão alerta que não se trata de um princípio no sentido aqui empregado, uma vez que a adequação, a necessidade e a proporcionalidade em sentido estrito "não são sopesadas contra algo", não se podendo dizer que elas, às vezes, tenham precedência, e, às vezes, não. Assim, o que se indaga é se essas máximas parciais foram ou não satisfeitas, ao passo que "(...) sua não satisfação tem como consequência uma ilegalidade". Portanto, as referidas máximas parciais devem ser consideradas regras. ${ }^{235}$

Não é demais mencionar que a doutrina alexiana conceitua os princípios como mandamentos de otimização em face das possibilidades jurídicas e fáticas. A máxima da proporcionalidade em sentido estrito, é dizer, a exigência de sopesamento, decorre da relativização em face das possibilidades jurídicas. Quando deparamo-nos com uma colisão entre uma norma de direito fundamental com caráter de princípio e um princípio antagônico, a possibilidade jurídica para a realização dessa norma depende do princípio antagônico. Nos termos da chamada "lei de colisão", faz-se necessário o sopesamento para que se possa chegar a uma decisão. ${ }^{236}$

\footnotetext{
${ }^{233}$ ALEXY, Robert. Teoria dos Direitos Fundamentais, 2. ed., Tradução de Virgílio Afonso da Silva da $5^{\text {a }}$ edição alemã Theorie der Grundrechte. São Paulo: Malheiros Editores, 2009, p. 116-117.

${ }^{234}$ ALEXY, Robert. Teoria dos Direitos Fundamentais, 2. ed., Tradução de Virgílio Afonso da Silva da $5^{\text {a }}$ edição alemã Theorie der Grundrechte. São Paulo: Malheiros Editores, 2009, p. 117 Cf. BVerfGE 19, 342 (348349); 65,1 (44).

${ }^{235}$ ALEXY, Robert. Teoria dos Direitos Fundamentais, 2. ed., Tradução de Virgílio Afonso da Silva da $5^{\text {a }}$ edição alemã Theorie der Grundrechte. São Paulo: Malheiros Editores, 2009, p. 117 Cf. HAVERKATE, Görg. Rechtsfragen des Leistungsstaats. Tübingen: Mohr, 1983, p. 11.

${ }^{236}$ ALEXY, Robert. Teoria dos Direitos Fundamentais, 2. ed., Tradução de Virgílio Afonso da Silva da $5^{\text {a }}$ edição alemã Theorie der Grundrechte. São Paulo: Malheiros Editores, 2009, p. 117.
} 
Assim, diante da obrigatoriedade da aplicação de princípios válidos e da consequente necessidade de sopesamento - nos casos de colisão -, "o caráter principiológico das normas de direito fundamental implica a necessidade de um sopesamento quando elas colidem com princípios antagônicos”, o que significa que “(...) a máxima da proporcionalidade em sentido estrito é deduzível do caráter principiológico das normas de direitos fundamentais". ${ }^{237}$

Sob tal perspectiva, a necessidade de sopesamento em casos de colisão é inerente ao caráter principiológico das normas de direito fundamental, do qual se pode extrair, então, a máxima da proporcionalidade em sentido estrito.

Ademais, ressalte-se que a máxima da proporcionalidade também serve como um indicador de existência de violação ao conteúdo essencial de um direito fundamental. Para Konrad Hesse, a restrição é violadora do conteúdo essencial sempre que ela não estiver "em uma relação apropriada como peso e a importância do direito fundamental". ${ }^{238}$

Por derradeiro, Alexy busca demonstrar como a máxima da necessidade decorre do caráter principiológico das normas. Para isso, ele elege uma "constelação mais simples", caracterizada pela presença de dois princípios e dois sujeitos de direito (Estado/cidadão). Essa constelação obedece a seguinte estrutura:

(...) o Estado fundamenta a persecução do objetivo $\mathrm{Z}$ com base no princípio $\mathrm{P}_{1}$ (ou $\mathrm{Z}$ é simplesmente idêntico a $\mathrm{P}_{1}$ ). Há pelo menos duas medidas, $\mathrm{M}_{1}$ e $\mathrm{M}_{2}$, para realizar ou fomentar $\mathrm{Z}$, e ambas são igualmente adequadas. $\mathrm{M}_{2}$ afeta menos intensamente que $\mathrm{M}_{1}$ - ou simplesmente não afeta - a realização daquilo que uma norma de direito fundamental com estrutura de princípio $-\mathrm{P}_{2}-$ exige. ${ }^{239}$

Nesse sentido, $P_{1}$ não exige que se escolha $M_{1}$ ou $M_{2}$, pois tal escolha resta, para $P_{1}$, indiferente. Por sua vez, $\mathrm{P}_{2}$ exige uma otimização tanto em relação às possibilidades fáticas como em relação às possibilidades jurídicas. No que tange às possibilidades fáticas, $\mathrm{P}_{2}$ é realizado em maior medida se se escolhe $\mathrm{M}_{2}$. Alexy assevera que tal raciocínio é aplicável a quaisquer princípios, objetivos e medidas. Por conseguinte, o exame de necessidade, definido pelo Tribunal Constitucional Federal alemão como a "exigência de que o objetivo não possa ser igualmente realizado por meio de outra medida, menos gravosa ao indivíduo", decorre do caráter principiológico das normas de direitos fundamentais. ${ }^{240}$

\footnotetext{
${ }^{237}$ ALEXY, Robert. Teoria dos Direitos Fundamentais, 2. ed., Tradução de Virgílio Afonso da Silva da $5^{\mathrm{a}}$ edição alemã Theorie der Grundrechte. São Paulo: Malheiros Editores, 2009, p. 118.

${ }^{238}$ HESSE, Konrad, Grundzüge des Verfassungsrechts, $\S 332$ e ss apud ALEXY, Robert. Teoria dos Direitos Fundamentais, 2. ed., Tradução de Virgílio Afonso da Silva da $5^{\text {a }}$ edição alemã Theorie der Grundrechte. São Paulo: Malheiros Editores, 2009, p. 131.

${ }^{239}$ ALEXY, Robert. Teoria dos Direitos Fundamentais, 2. ed., Tradução de Virgílio Afonso da Silva da $5^{\text {a }}$ edição alemã Theorie der Grundrechte. São Paulo: Malheiros Editores, 2009, p. 118-119.

240 ALEXY, Robert. Teoria dos Direitos Fundamentais, 2. ed., Tradução de Virgílio Afonso da Silva da $5^{\mathrm{a}}$ edição alemã Theorie der Grundrechte. São Paulo: Malheiros Editores, 2009, p. 119 Cf. BVerfGE 38, 281 (302)
} 
Entretanto, ressalta ainda o doutrinador, que, o fato de uma das duas alternativas tenha que ser escolhida não se configura, como uma questão de possibilidades fáticas, ou seja, não se trata de uma questão para o exame da necessidade, mas uma questão de possibilidades jurídicas, isto é, uma questão de sopesamento entre $\mathrm{P}_{1}$ e $\mathrm{P}_{2}$ - proporcionalidade em sentido estrito. $^{241}$ Com isso, Alexy intenta demonstrar que a exigência do sopesamento mostrar-se-á presente ao exame da necessidade.

Utilizando-se dessa linha de raciocínio, Alexy defende que também o exame da adequação decorre do caráter principiológico das normas de direitos fundamentais. No caso, se $\mathrm{M}_{1}$ não é adequada para a realização do objetivo $\mathrm{Z}$ (que é requerido por $\mathrm{P}_{1}$ ou é idêntico a ele), então $\mathrm{M}_{1}$ não é exigida por $\mathrm{P}_{1}$. Para $\mathrm{P}_{1}$ é indiferente a adoção de ou não de $\mathrm{M}_{1}$. Mas se $\mathrm{M}_{1}$ afeta a realização de $\mathrm{P}_{2}$, então, a adoção de $\mathrm{M}_{1}$ é vedada por $\mathrm{P}_{2}$, sob o aspecto da otimização em relação às possibilidades fáticas. ${ }^{242}$ Nesse sentido, Alexy cita o doutrinador alemão Eberhard Grabitz, segundo o qual:

Se se concebe o princípio que subjaz aos direitos de liberdade de forma positiva como a maior chance possível de desenvolvimento da personalidade garantida ao indivíduo em virtude da Constituição, então, toda regulação "excessiva" frustra a maximização de chances e é, por isso, constitucionalmente ilegítima. ${ }^{243}$

A dedução exposta por Alexy consiste em uma fundamentação ${ }^{244}$ da máxima da proporcionalidade a partir das normas de direitos fundamentais, na medida em que tenham caráter de princípio.

\subsection{A INACEITABILIDADE DO MODELO PURO DE PRINCÍPIOS E DO MODELO PURO DE REGRAS}

O modelo puro de princípios, elaborado por Eike Von Hippel ${ }^{245}$, sugere serem as normas de direitos fundamentais meras normas de princípios, indicadoras de que, na solução

\footnotetext{
${ }^{241}$ ALEXY, Robert. Teoria dos Direitos Fundamentais, 2. ed., Tradução de Virgílio Afonso da Silva da $5^{\mathrm{a}}$ edição alemã Theorie der Grundrechte. São Paulo: Malheiros Editores, 2009, p. 119-120.

242 ALEXY, Robert. Teoria dos Direitos Fundamentais, 2. ed., Tradução de Virgílio Afonso da Silva da $5^{\mathrm{a}}$ edição alemã Theorie der Grundrechte. São Paulo: Malheiros Editores, 2009, p. 120.

${ }^{243}$ GRABITZ, Eberhard. Der Grundsatz der Verhältnismäßigkeit in der Rechtsprechung des

Bundesverfassungsgerichts, p. 586 apud ALEXY, Robert. Teoria dos Direitos Fundamentais, 2. ed., Tradução de Virgílio Afonso da Silva da $5^{\text {a }}$ edição alemã Theorie der Grundrechte. São Paulo: Malheiros Editores, 2009, p. 120 .

${ }^{244}$ Também chamada, por Alexy, de "fundamentação a partir dos direitos fundamentais" Cf. ALEXY, Robert. Teoria dos Direitos Fundamentais, 2. ed., Tradução de Virgílio Afonso da Silva da $5^{\mathrm{a}}$ edição alemã Theorie der Grundrechte. São Paulo: Malheiros Editores, 2009, p. 120.
} 
de conflitos, deve-se conferir a determinados direitos um peso especial. Mais especificamente, esses direitos merecedores de um peso especial configurariam interesses de liberdade, como liberdades de crença, de opinião, de profissão, de propriedade etc., em suma, à ideia de autodeterminação individual. Nesse sentido, v. Hippel parte de uma fórmula geral segundo a qual "toda norma de direito fundamental vale somente se e na medida em que a um interesse de liberdade protegido não forem contrapostos interesses (bens jurídicos) de maior valor". ${ }^{246}$

A partir de então, Alexy rejeita essa teoria sob o fundamento de que ela não leva a sério a Constituição escrita, tendo em vista que esta rejeita, expressamente, a existência de uma cláusula geral de restrição. É certo que o Tribunal Constitucional Federal alemão trata as normas de direitos fundamentais como princípios, mas ressalta a importância das regras, quando menciona a importância de uma "cuidadosa regulação das restrições, ajustada à natureza de cada um dos direitos fundamentais". ${ }^{247}$ Portanto, de acordo com Alexy e Thomas Wülfing, a partir do momento em que um modelo puro de princípios não leva a sério essa regulação, já é digno de críticas, pela nítida contrariedade ao texto constitucional. ${ }^{248}$ É certo que, em determinados casos, é possível se desviar do texto constitucional, mas apenas por razões especiais, em respeito à sua força vinculante.

Por sua vez, de acordo com o modelo puro de regras, as normas de direitos fundamentais, por mais que necessitem de complementação, são sempre aplicáveis sem o recurso a ponderações, configurando-se, portanto, normas livres de sopesamentos. Tal característica já se mostra suficiente para se questionar o modelo puro de princípios, para Alexy, que direciona suas indagações em relação a três tipos importantes de normação dos direitos fundamentais, a saber: os direitos fundamentais sem reserva, os direitos fundamentais com reserva simples e os direitos fundamentais com reserva qualificada. ${ }^{249}$

No caso dos direitos fundamentais garantidos sem reserva, que conduzem aqueles que se baseiam tão somente no texto dos dispositivos acerca desses direitos, chega-se à conclusão da não possibilidade de restrições à liberdade de crença, à liberdade artística, e ao direito de se

\footnotetext{
${ }^{245}$ HIPPEL, Eike v. Grenzen und Wesensgehalt der Grundrechte, p. 15-16 apud ALEXY, Robert. Teoria dos Direitos Fundamentais, 2. ed., Tradução de Virgílio Afonso da Silva da $5^{\text {a }}$ edição alemã Theorie der Grundrechte. São Paulo: Malheiros Editores, 2009, p. 121 ss.

${ }^{246}$ HIPPEL, Eike v. Grenzen und Wesensgehalt der Grundrechte, p. 25-30 apud ALEXY, Robert. Teoria dos Direitos Fundamentais, 2. ed., Tradução de Virgílio Afonso da Silva da $5^{\text {a }}$ edição alemã Theorie der Grundrechte. São Paulo: Malheiros Editores, 2009, p. 121 ss.

${ }^{247}$ ALEXY, Robert. Teoria dos Direitos Fundamentais, 2. ed., Tradução de Virgílio Afonso da Silva da $5^{\mathrm{a}}$ edição alemã Theorie der Grundrechte. São Paulo: Malheiros Editores, 2009, p. 122 Cf. BVerfGE 32, 54 (75).

${ }^{248}$ ALEXY, Robert. Teoria dos Direitos Fundamentais, 2. ed., Tradução de Virgílio Afonso da Silva da $5^{\text {a }}$ edição alemã Theorie der Grundrechte. São Paulo: Malheiros Editores, 2009, p. 122 Cf. WÜLFING, Thomas, Grundrechtliche Gesetzesvorbehalte und Grundrechtsschranken, Berlin: Duncker \& Humblot, 1981, p. 21. ${ }^{249}$ ALEXY, Robert. Teoria dos Direitos Fundamentais, 2. ed., Tradução de Virgílio Afonso da Silva da $5^{\text {a }}$ edição alemã Theorie der Grundrechte. São Paulo: Malheiros Editores, 2009, p. 123.
} 
recusar o serviço militar, por exemplo. Aqui, Alexy ${ }^{250}$ pretende analisar se é possível, no âmbito dos direitos fundamentais garantidos sem reservas, estabelecer critérios que propiciem decisões acerca da extensão da proteção de um direito fundamental sem o recurso a qualquer forma de sopesamento. Para isso, o doutrinador cita a teoria que, à primeira vista, parece prescindir de sopesamentos, a teoria das restrições imanente de não-perturbação de Dürig ${ }^{251}$, e questiona se realmente as cláusulas ${ }^{252}$ elaboradas por esta teoria são livres de sopesamento.

Dürig menciona que há suportes fáticos onde normalmente são estabelecidas "restrições óbvias de não-perturbação" 253 . A partir dessa afirmação, Alexy entende que a análise em torno da legitimidade das restrições aos direitos fundamentais trata-se de se levar em consideração uma referência ao que é óbvio, o que "significaria dar uma resposta racionalmente não-controlável, o que conduziria a um intuicionismo no âmbito dos direitos fundamentais". ${ }^{254}$ Assim, ao contrário do que ocorre em condições concretas de precedência, as cláusulas abstratas de restrição frequentemente ocasionam casos duvidosos, devido a sua abertura e variedade de relações jurídicas no âmbito dos direitos fundamentais. Portanto, "nesses casos duvidosos o sopesamento volta a ser relevante". Nesse sentido, vale mencionar o delineamento da necessidade do sopesamento defendido por Alexy, em casos duvidosos:

(...) cláusulas que independam de sopesamento pode, em alguma medida, servir como regra geral, mas sua correção continua dependente dos sopesamentos que a elas subjazem. Quando surgem dúvidas, o sopesamento é inafastável. Portanto, critérios livres de sopesamento são, na verdade, sempre o resultado de um sopesamento que os sustenta e, na melhor das hipóteses, podem resumi-lo de maneira geral. Um acesso direto - ou "intuitivo" - a eles é algo que não satisfaz as exigências de uma fundamentação racional e, por isso, fracassa nos casos duvidosos. A impressão intuitiva de sua correção ou de seu caráter evidente - que surge em vários casos - decorre da obviedade dos pesos atribuídos aos princípios em colisão. $^{255}$

\footnotetext{
${ }^{250}$ ALEXY, Robert. Teoria dos Direitos Fundamentais, 2. ed., Tradução de Virgílio Afonso da Silva da $5^{\text {a }}$ edição alemã Theorie der Grundrechte. São Paulo: Malheiros Editores, 2009, p. 124 ss.

${ }^{251}$ DÜRIG, Günther. Art. 2 Abs. 1 apud ALEXY, Robert. Teoria dos Direitos Fundamentais, 2. ed., Tradução de Virgílio Afonso da Silva da $5^{\mathrm{a}}$ edição alemã Theorie der Grundrechte. São Paulo: Malheiros Editores, 2009 , p. 124 ss.

${ }^{252}$ Dürig elabora uma tríade de restrições originárias de não-perturbação: a restrição imanente lógico-jurídica, atribuída a direitos de terceiros; a restrição socialmente imanente, atribuída à ordem constitucional; e a restrição eticamente imanente, atribuída à lei moral. Cf. DÜRIG, Günther. Art. 2 Abs. 1, in Theodor Maunz/ Günther Dürig, Grundgesetz, § 70.

${ }^{253}$ DÜRIG, Günther. Art. 2 Abs. 1 apud ALEXY, Robert. Teoria dos Direitos Fundamentais, 2. ed., Tradução de Virgílio Afonso da Silva da $5^{\mathrm{a}}$ edição alemã Theorie der Grundrechte. São Paulo: Malheiros Editores, 2009 , p. 124 ss.

${ }^{254}$ ALEXY, Robert. Teoria dos Direitos Fundamentais, 2. ed., Tradução de Virgílio Afonso da Silva da $5^{\text {a }}$ edição alemã Theorie der Grundrechte. São Paulo: Malheiros Editores, 2009, p. 124 ss.

255 ALEXY, Robert. Teoria dos Direitos Fundamentais, 2. ed., Tradução de Virgílio Afonso da Silva da $5^{\mathrm{a}}$ edição alemã Theorie der Grundrechte. São Paulo: Malheiros Editores, 2009, p. 128.
} 
Acerca da "restrição eticamente imanente da lei moral", também proposta por Dürig, Alexy defende uma única tese, é dizer, a tese de que a lei moral, independente do conceito a qual se empregue, enquanto restrição a direitos fundamentais, jamais poderá ser uma cláusula livre de sopesamentos. Isso se justifica pelo fato de os próprios direitos fundamentais a serem restringidos são dotados de conteúdo moral e, além disso, para que seja juridicamente relevante, a lei moral deverá “(...) dizer respeito a relações entre indivíduos, bem como entre indivíduos e coletividade", o que implica na inafastabilidade dos sopesamentos, diante dos casos concretos. $^{256}$

Já no caso das normas de direitos fundamentais com reserva simples, Alexy explica que o problema está no fato de que elas garantem pouca coisa, uma vez que ao se levar em consideração apenas o texto constitucional, os direitos fundamentais garantidos com reserva simples "ficam esvaziados na parte que está além de seu conteúdo essencial". Esse esvaziamento pode ser evitado mediante uma garantia do conteúdo essencial que se estenda a toda intervenção em um direito fundamental, ou mediante a introdução de um critério adicional não escrito capaz de limitar a competência do legislador para impor restrições. Nesse sentido, “(...) a garantia do conteúdo essencial é estendida a todos os direitos fundamentais pelas chamadas teorias relativas, segundo as quais uma restrição atinge o conteúdo essencial de um direito fundamental se ela for desproporcional". ${ }^{257} \mathrm{Ou}$ seja, e de acordo com a doutrina de Konrad Hesse, se a restrição for inadequada, desnecessária ou desproporcional em sentido estrito, não estando "em uma relação apropriada com o peso e a importância do direito fundamental". ${ }^{258}$

Por fim, Alexy ressalta a impossibilidade de uma solução que prescinda de sopesamentos, sendo que a jurisprudência alemã encontra-se alinhada com a teoria dos princípios, exigindo-se para todos os casos de restrição a direitos fundamentais, o atendimento das máximas da adequação, da necessidade e da proporcionalidade em sentido estrito. Assim, segundo o jusfilósofo alemão, o modelo puro de regras fracassa também no caso dos direitos fundamentais garantidos com reserva simples. ${ }^{259}$

\footnotetext{
${ }^{256}$ ALEXY, Robert. Teoria dos Direitos Fundamentais, 2. ed., Tradução de Virgílio Afonso da Silva da $5^{\mathrm{a}}$ edição alemã Theorie der Grundrechte. São Paulo: Malheiros Editores, 2009, p. 128-129.

257 ALEXY, Robert. Teoria dos Direitos Fundamentais, 2. ed., Tradução de Virgílio Afonso da Silva da $5^{\mathrm{a}}$ edição alemã Theorie der Grundrechte. São Paulo: Malheiros Editores, 2009, p. 130-131.

${ }^{258}$ HESSE, Konrad, Grundzüge des Verfassungrechts, $\S \S 332$ e ss apud ALEXY, Robert. Teoria dos Direitos Fundamentais, 2. ed., Tradução de Virgílio Afonso da Silva da $5^{a}$ edição alemã Theorie der Grundrechte. São Paulo: Malheiros Editores, 2009, p. 131.

${ }^{259}$ ALEXY, Robert. Teoria dos Direitos Fundamentais, 2. ed., Tradução de Virgílio Afonso da Silva da $5^{\text {a }}$ edição alemã Theorie der Grundrechte. São Paulo: Malheiros Editores, 2009, p.131.
} 
Também insuficiente se revela o modelo puro de regras nos casos dos direitos fundamentais garantidos com reserva qualificada. Para isso, Alexy cita o artigo 13 da Lei Fundamental alemã - da inviolabilidade de domicílio, e o respectivo parágrafo $3^{\circ}$, que estabelece cláusulas de restrição. E explica que o referido dispositivo se refere tão somente àquilo que se inclui no teor do suporte fático da garantia constitucional, e caso essa garantia seja estendida para além do seu teor literal, mediante a aposição de uma regra que estenda a proteção do direito fundamental, com base no caráter principiológico do art. 13, "então, o alcance dessa restrição não está vinculado ao teor das cláusulas de restrição do art. $13, \S 3^{\circ}$, porque estas se referem somente àquilo que se inclui no teor literal do suporte fático". ${ }^{260}$

Finalmente, diante da compreensão do fracasso tanto o modelo puro de regras como do modelo puro de princípios, Alexy propõe que se considere a possibilidade de um modelo combinado: o modelo de regras e princípios, que emana da ligação entre um nível de princípios e um nível de regras. $^{261}$

\subsection{PRINCÍPIO E VALOR}

Em resposta à objeção que associa a teoria dos princípios à teoria dos valores, Alexy tece algumas considerações. Apesar de reconhecer a íntima relação a que estão passíveis os princípios e os valores, uma vez que é possível falar em colisão e em sopesamento tanto em princípios como em valores, assim como é possível afirmar que a realização gradual dos princípios corresponde à realização gradual dos valores, Alexy aponta para uma diferença importante entre valor e princípio.

Para isso, ele ressalta a contribuição trazida por Von Wright ${ }^{262}$, que propõe a divisão de conceitos básicos, divididos em três grupos: os deontológicos ${ }^{263}$, os axiológicos ${ }^{264}$ e os

\footnotetext{
${ }^{260}$ ALEXY, Robert. Teoria dos Direitos Fundamentais, 2. ed., Tradução de Virgílio Afonso da Silva da $5^{\mathrm{a}}$ edição alemã Theorie der Grundrechte. São Paulo: Malheiros Editores, 2009, p.135.

${ }^{261}$ ALEXY, Robert. Teoria dos Direitos Fundamentais, 2. ed., Tradução de Virgílio Afonso da Silva da $5^{\mathrm{a}}$ edição alemã Theorie der Grundrechte. São Paulo: Malheiros Editores, 2009, p.135.

${ }^{262}$ WRIGHT, Georg Henrik v. The Logic of Preference, p. 7 apud ALEXY, Robert. Teoria dos Direitos

Fundamentais, 2. ed., Tradução de Virgílio Afonso da Silva da $5^{a}$ edição alemã Theorie der Grundrechte. São Paulo: Malheiros Editores, 2009, p. 145.

${ }^{263}$ Os conceitos deontológicos são conceitos referentes ao dever, proibição, permissão e direito a algo.

${ }^{264}$ Os conceitos axiológicos referem-se ao conceito de bom, e possuem abertura para a variedade dessa compreensão, sendo utilizados quando algo é classificado como bonito, corajoso, seguro, econômico, democrático, social, liberal ou compatível com o Estado de Direito. Cf. ALEXY, Robert. Teoria dos Direitos Fundamentais, 2. ed., Tradução de Virgílio Afonso da Silva da $5^{a}$ edição alemã Theorie der Grundrechte. São Paulo: Malheiros Editores, 2009, p. 145.
} 
$\operatorname{antropológicos}^{265}$. A partir dessa tripartição, queda-se mais fácil o entendimento da diferença entre os conceitos de princípio e de valor. Sob a ótica da doutrina alexiana, temos que princípios são mandamentos de um determinado tipo, é dizer, mandamentos de otimização. Enquanto mandamentos, eles pertencem ao âmbito deontológico. Por sua vez, os valores são inerentes ao domínio axiológico. ${ }^{266}$

No presente cenário, vale destacar que valorações baseiam-se em diferentes critérios, entre os quais é necessário sopesar, uma vez que esses critérios competem entre si. Somente mediante uma valoração global podemos chegar, então, à classificação de algo como "bom". Nesse sentido, “a aplicação de critérios de valoração entre os quais é necessário sopesar corresponde à aplicação de princípios". A partir dessa percepção, a doutrina alexiana passa a classificar somente aqueles critérios passíveis de sopesamento enquanto critérios de valoração. Como contraponto, temos os critérios de valoração que, assim como as regras, são aplicáveis independentemente de sopesamento. Estes critérios são chamados, por Alexy, de regras de valoração. ${ }^{267}$

Também no nível axiológico seria possível verificar a diferença estrutural entre regras e princípios, uma vez que "aos princípios correspondem os critérios de valoração", enquanto que às regras correspondem as regras de valoração. ${ }^{268}$

No âmbito das diferentes formas de juízos de valor, os juízos comparativos ganham maior destaque frente ao direito constitucional. Assim, por exemplo, com base no critério de valoração "liberdade de imprensa", uma situação $Z_{1}$, onde a liberdade de imprensa é realizada em maior grau que em $Z_{2}$, deve ser valorada como melhor que $Z_{2}$. Há a possibilidade de que $Z_{1}$ possa realizar a liberdade de imprensa em maior medida que $Z_{2}$ devido ao fato de que $Z_{1}$ caracterize-se por circunstâncias não presentes em $\mathrm{Z}_{2}$. Assim, a partir do critério de valoração "liberdade de imprensa", a situação $Z_{1}$, na qual o segredo de redação é protegido de forma ilimitada, deve ser valorada como melhor que uma situação semelhante $Z_{2}$, onde essa proteção não ocorre. Já perante o critério de valoração “segurança nacional”, é possível que o contrário ocorra. Assim, o sopesamento revela-se fundamental, já que não se pode renunciar a nenhum dos dois critérios de valoração. Contudo, isso significa “(...) que uma situação que, segundo o

\footnotetext{
${ }^{265}$ Já os conceitos antropológicos são conceitos de vontade, interesse, necessidade, decisão e ação. Cf. ALEXY, Robert. Teoria dos Direitos Fundamentais, 2. ed., Tradução de Virgílio Afonso da Silva da $5^{\text {a }}$ edição alemã Theorie der Grundrechte. São Paulo: Malheiros Editores, 2009, p. 145-146.

${ }^{266}$ ALEXY, Robert. Teoria dos Direitos Fundamentais, 2. ed., Tradução de Virgílio Afonso da Silva da $5^{\mathrm{a}}$ edição alemã Theorie der Grundrechte. São Paulo: Malheiros Editores, 2009, p. 146.

267 ALEXY, Robert. Teoria dos Direitos Fundamentais, 2. ed., Tradução de Virgílio Afonso da Silva da $5^{\text {a }}$ edição alemã Theorie der Grundrechte. São Paulo: Malheiros Editores, 2009, p. 150.

268 ALEXY, Robert. Teoria dos Direitos Fundamentais, 2. ed., Tradução de Virgílio Afonso da Silva da $5^{\mathrm{a}}$ edição alemã Theorie der Grundrechte. São Paulo: Malheiros Editores, 2009, p. 150.
} 
critério de valoração 'liberdade de imprensa', é melhor que outra, ou é a melhor de todas, é melhor apenas prima facie". Por derradeiro, "a decisão acerca da situação definitivamente melhor é obtida somente após uma valoração global, na qual todos os critérios válidos de valoração sejam levados em consideração". ${ }^{269}$

Assim, é possível reduzir a diferença entre princípios e valores a um ponto: no âmbito do modelo de valores, aquilo que é, prima facie, o melhor, será, no âmbito do modelo dos princípios, prima facie, devido; e aquilo que, no modelo dos valores, é definitivamente o melhor, será, no modelo dos princípios, definitivamente devido. Portanto, "princípios e valores diferenciam-se (...) somente em virtude de seu caráter deontológico, no primeiro caso, e axiológico, no segundo". 270

\subsection{A INDISPENSABILIDADE DO SOPESAMENTO}

\subsubsection{Sistema de valores e o sopesamento}

A partir do entendimento de que a teoria dos princípios e a teoria dos valores possuem a mesma essência, Alexy reconhece que as objeções direcionadas às teorias valorativas também poderão atingir a teoria dos princípios.

Antes de qualquer coisa, e a fim de realçar sua importância, vale lembrar que as teorias valorativas dos direitos fundamentais já eram defendidas na época da Constituição de Weimar. Rudolf Smend, autor influente, estabeleceu a propalada formulação de que "o sentido substancial de um catálogo de direitos fundamentais" consiste na sua pretensão de "normar uma série substantiva com um certo grau de unidade, isto é, um sistema de valores ou de bens, um sistema cultural". 271

O entendimento jurisprudencial emanado, por exemplo, pelo Tribunal Constitucional Federal alemão é no sentido de que "os direitos fundamentais são destinados, em primeira instância, a proteger a esfera de liberdade do indivíduo contra intervenções dos poderes públicos". Ou seja, os direitos fundamentais constituem "direitos de defesa do cidadão contra o Estado". Ademais, o Tribunal acrescenta que a Constituição não pretende ser uma

\footnotetext{
${ }^{269}$ ALEXY, Robert. Teoria dos Direitos Fundamentais, 2. ed., Tradução de Virgílio Afonso da Silva da $5^{\text {a }}$ edição alemã Theorie der Grundrechte. São Paulo: Malheiros Editores, 2009, p. 152-153.

${ }^{270}$ ALEXY, Robert. Teoria dos Direitos Fundamentais, 2. ed., Tradução de Virgílio Afonso da Silva da $5^{\text {a }}$ edição alemã Theorie der Grundrechte. São Paulo: Malheiros Editores, 2009, p. 153.

${ }^{271}$ SMEND, Rudolf. Verfassung und Verfassungsrecht (1928). In: Staatsrechtliche Abhandlungen, 2.ed. Berlin: Duncker \& Humblot, 1968, p. 264 apud ALEXY, Robert. Teoria dos Direitos Fundamentais, 2. ed., Tradução de Virgílio Afonso da Silva da $5^{a}$ edição alemã Theorie der Grundrechte. São Paulo: Malheiros Editores, 2009, p. 154.
} 
ordenação axiologicamente neutra, e que ela estabeleceu, na seção dedicada aos direitos fundamentais, uma ordem objetiva de valores. Esse sistema de valores, "em cujo centro se encontra o livre desenvolvimento da personalidade humana e de sua dignidade no seio da comunidade social" deve valer, enquanto decisão constitucional fundamental, para todos os ramos do direito. ${ }^{272}$ Ao analisar essa decisão, Alexy aponta para a qualificação da ordem de valores como "hierarquia de valores", onde um sopesamento se faz necessário. ${ }^{273}$

Em defesa do sistema de valores, o constitucionalista norte-americano Donald Kommers ressalta que "a genialidade do pensamento constitucional alemão está na identificação de um tal sistema na ordem hierárquica de valores do Tribunal Constitucional Federal". 274

\subsubsection{A (ir)racionalidade do sopesamento?}

Encontramos várias objeções à teoria dos valores, podendo reuni-las em três grupos: filosóficas, metodológicas e dogmáticas. No âmbito das objeções filosóficas que, por sua vez, dirigem-se sobretudo contra o conceito de objetividade da teoria dos valores, encontramos a crítica à ideia do sopesamento. Nesse ínterim, a grande objeção aponta que a teoria dos princípios é necessariamente incorreta porque pressupõe "sopesamentos e as insuportáveis inseguranças a eles ligadas". 275

Assim, os sopesamentos não permitiriam um modelo aberto a um controle racional. Os valores e os princípios não disciplinam sua aplicação, o que tornaria o sopesamento refém do arbítrio daquele que sopesa, abrindo espaço para o subjetivismo e o decisionismo dos juízes. Autores como Jürgen Habermas e Jiménez Campo ${ }^{276}$ sustentam que a ponderação representa nada mais que um juízo arbitrário e salomônico e que nem o Tribunal Constitucional está revestido de legitimidade constitucional suficiente para aplicar os princípios mediante esse procedimento.

\footnotetext{
${ }^{272}$ BVerfGE 7, 198 (204).

${ }^{273}$ ALEXY, Robert. Teoria dos Direitos Fundamentais, 2. ed., Tradução de Virgílio Afonso da Silva da $5^{\text {a }}$ edição alemã Theorie der Grundrechte. São Paulo: Malheiros Editores, 2009, p. 154 Cf. BVerfGE 7, 198 (215). ${ }^{274}$ KOMMERS, Donald P. The constitutional jurisprudence of the Federal Republic of Germany. ${ }^{\text {rd }}$ ed., rev and expanded, p. 42 ss.

${ }^{275}$ ALEXY, Robert. Teoria dos Direitos Fundamentais, 2. ed., Tradução de Virgílio Afonso da Silva da $5^{\text {a }}$ edição alemã Theorie der Grundrechte. São Paulo: Malheiros Editores, 2009, pp. 144, 155 e 163.

${ }^{276}$ HABERMAS, Jürgen. Facticidad y Validez. Sobre el derecho y el Estado democrático de derecho en términos de teoría del discurso (traducción de Manuel Jiménez Redondo), Trotta, Madrid, 1998, págs. 327 y sigs.; JIMÉNEZ CAMPO, Javier. Derechos Fundamentales. Concepto y garantías, Trotta, Madrid, 1999, pág. 73.
} 
Há quem aponte o sopesamento como mera fórmula retórica ${ }^{277}$, eivada de imprecisões e de incomensurabilidade, uma vez que o âmbito dos princípios carece de uma "unidade de medida" 278 , e tampouco existe uma "moeda comum que possibilite a ponderação" 279 entre princípios colidentes. Grégoire C. N. Webber ${ }^{280}$, por sua vez, critica o sopesamento por sua prestensão de escapar das questões políticas e morais, além de "falhar" no intento de fornecer respostas categóricas e faz com que os direitos percam "any sense of certainty". ${ }^{281}$

A partir das referidas críticas, Carlos B. Pulido ${ }^{282}$ assevera que muitos de seus aspectos devem ser rechaçados devido ao seu caráter hiper-racional e, portanto, irracional. De acordo com John Elster ${ }^{283}$, alguém é hiper-racional quando não reconhece que a racionalidade encontra certos limites. É certo que o sopesamento, por não ter um caráter essencialmente formal, não é capaz de excluir apreciações subjetivas do juiz. ${ }^{284}$

Bernal Pulido reconhece que a indeterminação normativa abre sempre as portas para apreciações subjetivas do juiz. E mais, acrescenta o doutrinador: "Todo aquél que pretenda excluir de la ponderación las apreciaciones subjetivas del juez, incurre en hiperracionalidad". 285

Virgílio Afonso da Silva ${ }^{286}$, que adotou a teoria hegemônica do sopesamento de Alexy, reconhece que o sopesamento não envolve um raciocínio isento de valores, puramente lógico e imune a influências subjetivas, bem como a considerações morais. Acrescenta o autor que “ (...) the faith that balancing as well as the principle of proportionality turn 'the review

\footnotetext{
${ }^{277}$ LEISNER, Walter. Der Abwägungsstaat. Duncker \& Humblot, Berlin, 1997, pág. 171 apud PULIDO, Carlos Bernal. La Racionalidad de la Ponderación. In: Revista Española de Derecho Constitucional, ISSN: 0211-5743, n. 77, mayo-agosto, 2006, p. 53.

${ }^{278}$ HABERMAS, Jürgen. Anhang zu Faktizität und Geltung. Replik auf Beiträge zu einem Symposion der Cardozo Law School. In: ID.: Die Einbeziehung des Anderen. Studien zur politischen Theorie, Frankfurt a. M., 1996, pág. 369 apud PULIDO, Carlos Bernal. La Racionalidad de la Ponderación. In: Revista Española de Derecho Constitucional, ISSN: 0211-5743, n. 77, mayo-agosto, 2006, p. 53.

${ }^{279}$ ALEXANDER ALEINIKOFF, THOMAS. Constitutional Law en the Age of Balancing. Yale Law Journal, núm. 96, 1987, pág. 973 apud PULIDO, Carlos Bernal. La Racionalidad de la Ponderación. In: Revista Española de Derecho Constitucional, ISSN: 0211-5743, n. 77, mayo-agosto, 2006, p. 53.

${ }^{280}$ WEBBER, Grégoire C. N.. The Negotiable Constitution: On the Limitation of Rights. New York: Cambridge University Press, 2009, p. 105.

${ }^{281}$ WEBBER, Grégoire C. N.. The Negotiable Constitution: On the Limitation of Rights. New York: Cambridge University Press, 2009, p. 103-110.

${ }^{282}$ PULIDO, Carlos Bernal. La Racionalidad de la Ponderación. In: Revista Española de Derecho Constitucional, ISSN: 0211-5743, n. 77, mayo-agosto, 2006, p. 55.

${ }^{283}$ ELSTER, John. Juicios salomónicos. Las limitaciones de la racionalidad como principio de decisión (traducción de Carlos Gardini). Gedisa, Barcelona, 1999, p. 11 e ss.

${ }^{284}$ PULIDO, Carlos Bernal. La Racionalidad de la Ponderación. In: Revista Española de Derecho Constitucional, ISSN: 0211-5743, n. 77, mayo-agosto, 2006, p. 55.

${ }^{285}$ PULIDO, Carlos Bernal. La Racionalidad de la Ponderación. In: Revista Española de Derecho Constitucional, ISSN: 0211-5743, n. 77, mayo-agosto, 2006, p. 55-56.

${ }^{286}$ SILVA, Virgílio Afonso da. Comparing the Incommensurable: Constitutional Principles, Balancing and Rational Decision. Oxford Journal of Legal Studies, n. 31, p. 273-301, 2011.
} 
process into a relatively straightforward exercise of logical or syllogistic reasoning' or that subjective points of view 'never come into play', is a very naive approach". ${ }^{287}$

Com a adoção de diversas apreciações normativas e empíricas relativas a controvérsias, o juiz deparar-se-á com interpretações acerca de, por exemplo, de que tanta liberdade deve dispor o indivíduo em um Estado Constitucional e que restrições devem ser impostas aos princípios, e até que ponto pode um Estado Social intervir na economia a fim de garantir a redistribuição de condições materiais. Nesse sentido, Bernal Pulido, descartando a possibilidade de existência de uma única resposta correta, assevera que “ (...) no puede esperarse que, ni aún en el sistema constitucional más preciso, exista una única respuesta correcta para controversias de esta magnitud y complejidad". ${ }^{288}$ Não obstante, assevera ainda o autor, o fato de que a perfeita objetividade seja utópica por natureza não significa que se deva renunciar à tentativa de alcançá-la na maior medida possível. ${ }^{289}$

Bernal Pulido intenta demonstrar a possibilidade de se conferir ao sopesamento uma estrutura clara e precisa. E, para isso, ele realiza uma análise em torno da "fórmula do peso" proposta por Robert Alexy, e se tal propositura permite a existência de um modelo dotado das características a que se busca. ${ }^{290}$

\subsubsection{O modelo de sopesamento baseado na teoria dos princípios de Alexy}

Ao refutar as já mencionadas objeções, Alexy assegura que elas seriam procedentes se com elas se quer dizer que o sopesamento não é um procedimento capaz de conduzir, “(...) em todo e qualquer caso, a um resultado único e inequívoco", o que não ocorre. ${ }^{291}$

O sopesamento veio explicitamente à tona em decisões do Tribunal Constitucional Federal alemão e da Suprema Corte americana ao final dos anos 1950 e início dos anos 1960. Os primeiros casos de uso da ponderação, ou balancing, referiam-se ao julgamento de casos envolvendo a liberdade de expressão. ${ }^{292}$

\footnotetext{
${ }^{287}$ SILVA, Virgílio Afonso da. Comparing the Incommensurable: Constitutional Principles, Balancing and Rational Decision. Oxford Journal of Legal Studies, n. 31, p. 273-301, 2011.

${ }^{288}$ PULIDO, Carlos Bernal. La Racionalidad de la Ponderación. In. Revista Española de Derecho Constitucional, ISSN: 0211-5743, n. 77, mayo-agosto, 2006, p. 57.

${ }^{289}$ PULIDO, Carlos Bernal. La Racionalidad de la Ponderación. In: Revista Española de Derecho Constitucional, ISSN: 0211-5743, n. 77, mayo-agosto, 2006, p. 57.

${ }^{290}$ PULIDO, Carlos Bernal. La Racionalidad de la Ponderación. In. Revista Española de Derecho Constitucional, ISSN: 0211-5743, n. 77, mayo-agosto, 2006, p. 59.

${ }^{291}$ ALEXY, Robert. Teoria dos Direitos Fundamentais, 2. ed., Tradução de Virgílio Afonso da Silva da $5^{\text {a }}$ edição alemã Theorie der Grundrechte. São Paulo: Malheiros Editores, 2009, p. 164.

${ }^{292}$ BOMHOFF, Jacco. Balancing Constitutional Rights: The Origins and Meanings of Postwar Legal Discourse. Cambridge University Press, p. 29.
} 
Ao admitir que as regras são aplicadas por meio da subsunção, enquanto os princípios são aplicados mediante a ponderação, Carlos Bernal Pulido reconhece a ponderação como “(...) un criterio metodológico básico para la aplicación jurídica, en especial, para la aplicación jurídica de los derechos fundamentales". 293 O autor verifica que, em oposição a um modelo como o proposto por Rawls, que pretende defender a regra da prioridade absoluta do seu primeiro princípio de justiça sobre o segundo e, como consequência, que "a liberdade só pode ser restringida em razão da própria liberdade" ${ }^{294}$, Alexy conceitua o sopesamento enquanto uma estrutura por meio da qual não se estabelece uma relação absoluta, mas uma relação de precedência condicionada entre os princípios, à luz das circunstâncias do caso, a fim de determinar o sentido da decisão judicial. ${ }^{295}$

Para atender à exigência da realização dos princípios na "maior medida possível", os sectários da teoria alexiana deparam-se com a necessidade de contrastar o princípio em jogo com os demais princípios que jogam em sentido contrário, ou ainda com os princípios que fundamentam as regras que jogam em sentido contrário. Nesse cenário, princípios entram em colisão. Eles fundamentam prima facie normas incompatíveis. ${ }^{296}$

A doutrina alexiana demonstra que as colisões entre princípios devem ser resolvidas mediante a definição de uma relação de precedências condicionadas. Mas o sopesamento não se resume, para Alexy, à formulação de um enunciado de preferências e, por derradeiro, à determinação de uma regra relacionada ao caso - decorrente do enunciado. Se assim fosse, o sopesamento não representaria um procedimento racional. E "o estabelecimento de preferência condicionada poderia ocorrer de forma intuitiva", sendo que aquele que sopesa poderia seguir unicamente suas concepções subjetivas, o que não nos permitiria falar em sopesamentos corretos ou em sopesamentos equivocados. ${ }^{297}$

Contudo, "a um tal modelo decisionista de sopesamento pode ser contraposto um modelo fundamentado". ${ }^{298} \mathrm{Se}$, por um lado, o modelo decisionista implica na definição do enunciado de preferência como resultado de um "processo psíquico não controlável

\footnotetext{
${ }^{293}$ PULIDO, Carlos Bernal. La Racionalidad de la Ponderación. In: Revista Española de Derecho Constitucional, ISSN: 0211-5743, n. 77, mayo-agosto, 2006, p. 52.

${ }^{294}$ Cf. RAWLS, John. The Basic Liberties and Their Priority. In: ID.: The Tanner Lectures on Human Values, Salt Lake City, 1983.

${ }^{295}$ PULIDO, Carlos Bernal. La Racionalidad de la Ponderación. In: Revista Española de Derecho Constitucional, ISSN: 0211-5743, n. 77, mayo-agosto, 2006, p. 61.

${ }^{296}$ PULIDO, Carlos Bernal. La Racionalidad de la Ponderación. In. Revista Española de Derecho Constitucional, ISSN: 0211-5743, n. 77, mayo-agosto, 2006, p. 60.

${ }^{297}$ ALEXY, Robert. Teoria dos Direitos Fundamentais, 2. ed., Tradução de Virgílio Afonso da Silva da $5^{\text {a }}$ edição alemã Theorie der Grundrechte. São Paulo: Malheiros Editores, 2009, p. 164-165.

298 ALEXY, Robert. Teoria dos Direitos Fundamentais, 2. ed., Tradução de Virgílio Afonso da Silva da $5^{\mathrm{a}}$ edição alemã Theorie der Grundrechte. São Paulo: Malheiros Editores, 2009, p. 165.
} 
racionalmente", o modelo fundamentado, por outro lado, pressupõe conseguir discernir esse processo psíquico da fundamentação do enunciado de preferência. ${ }^{299}$

Alexy insiste em demonstrar a racionalidade de seu método: "um sopesamento é racional quando o enunciado de preferência, ao qual ele conduz, pode ser fundamentado de forma racional". A partir de então, somos direcionados à questão da possibilidade de fundamentação racional de enunciados que elaboram preferências condicionadas entre valores ou princípios colidentes. ${ }^{300}$

Alexy menciona decisão na qual o tribunal alemão faz referência a "um sopesamento global entre a intensidade da intervenção e o peso e a urgência das razões que a justificam". ${ }^{301}$ Tendo como ponto de partida manifestações como essas, que, segundo Alexy, fazem referência a uma regra que é constitutiva para os sopesamentos do Tribunal Constitucional Federal alemão, o doutrinador elabora a seguinte forma, enquanto reflexo dessa regra: “(A) Quanto maior for o grau de não-satisfação ou de afetação de um princípio, tanto maior terá que ser a importância da satisfação do outro". 302

A essa regra corresponde à chamada lei do sopesamento, válida para todos os tipos de sopesamento de princípios. Segundo essa lei, "a medida permitida de não-satisfação ou de afetação de um princípio depende do grau de importância da satisfação do outro". Da própria cláusula "dentro das possibilidades jurídicas" extraída do conceito de princípios, verifica-se que "aquilo que é exigido por um princípio foi inserido em uma relação com aquilo que é exigido pelo princípio colidente". Nesse sentido, a lei de colisão reflete em quê consiste essa relação.

Por conseguinte, Alexy utiliza-se da lei de colisão para aclarar a percepção de que " $o$ peso dos princípios não é determinado em si mesmo ou de forma absoluta" ${ }^{\text {"303 }}$, de modo que só é possível falar em pesos relativos.

Nesse ínterim, a lei do sopesamento aponta, primeiramente, para a importância da satisfação do princípio colidente e, em segundo lugar, para um dever. O sopesamento constitucional, ressalta Alexy, não se refere à importância que alguém confere à liberdade de imprensa ou à segurança nacional, por exemplo, mas à definição de qual deve ser a

\footnotetext{
${ }^{299}$ ALEXY, Robert. Teoria dos Direitos Fundamentais, 2. ed., Tradução de Virgílio Afonso da Silva da $5^{\text {a }}$ edição alemã Theorie der Grundrechte. São Paulo: Malheiros Editores, 2009, p. 165.

300 ALEXY, Robert. Teoria dos Direitos Fundamentais, 2. ed., Tradução de Virgílio Afonso da Silva da $5^{\text {a }}$ edição alemã Theorie der Grundrechte. São Paulo: Malheiros Editores, 2009, p. 165.

${ }^{301}$ BVerfGE 41, 251 (264) [sem grifo no original].

${ }^{302}$ ALEXY, Robert. Teoria dos Direitos Fundamentais, 2. ed., Tradução de Virgílio Afonso da Silva da $5^{\text {a }}$ edição alemã Theorie der Grundrechte. São Paulo: Malheiros Editores, 2009, p. 167.

303 ALEXY, Robert. Teoria dos Direitos Fundamentais, 2. ed., Tradução de Virgílio Afonso da Silva da $5^{\mathrm{a}}$ edição alemã Theorie der Grundrechte. São Paulo: Malheiros Editores, 2009, p. 167-168 [sem grifo no original].
} 
importância que se deve atribuir a ambas. Nesse sentido, é possível relacionar o sopesamento "a uma regra que prescreve como se deve sopesar". 304

Neste momento, Alexy intenta esclarecer as ideias que estão por trás da lei do sopesamento mediante a prescrição da definição de curvas de indiferença - como aquelas que são utilizadas nas ciências econômicas - às quais ele insere a lei do sopesamento em um metanível. $^{305}$ Mas aqui não se pretende ingressar a esse plano, inclusive porque Alexy reconhece que as curvas de indiferença não fornecem um procedimento decisório definitivo.

Não se olvide que, de acordo com a lei do sopesamento, a decisão que sopesa os princípios colidentes deve ser tomada com base no grau ou intensidade da não-satisfação ou da afetação de um princípio e, de outro lado, no grau de importância ou satisfação de outro princípio. Assim, aquele que defende que uma afetação muito intensa só poderia ser justificada por meio de um grau muito alto de importância da satisfação do princípio colidente ainda não diz quando essa afetação intensa e esse alto grau de importância estão presentes. Contudo, assevera Alexy, "ele diz o que deve ser fundamentado para justificar o enunciado de preferência que representa o resultado do sopesamento: enunciados sobre graus de afetação $e$ de importância". 306

Alexy assegura que o argumento contra a racionalidade dos sopesamentos não poderia basear-se meramente no fato de que valorações não definidas de forma cogente desempenham algum papel; mas "ele teria que se referir à extensão desse papel". 307

Alexy apoia-se num suposto modelo fundamentado que, segundo ele, evita uma série de dificuldades que estão frequentemente associadas à concepção de sopesamento. Esse modelo é capaz de afastar do sopesamento a precipitação, assim como um caráter abstrato ou generalizante. O modelo fundamentado resulta num enunciado de preferências condicionadas, ao qual, consoante a lei de colisão, corresponde uma regra de decisão diferenciada. ${ }^{308}$ Nesse sentido, do próprio conceito de princípio, extrai-se a constatação de que "os sopesamentos não são uma questão de tudo-ou-nada, mas uma tarefa de otimização".

\footnotetext{
${ }^{304}$ ALEXY, Robert. Teoria dos Direitos Fundamentais, 2. ed., Tradução de Virgílio Afonso da Silva da $5^{\text {a }}$ edição alemã Theorie der Grundrechte. São Paulo: Malheiros Editores, 2009, p. 169.

${ }^{305}$ Cf. ALEXY, Robert. Teoria dos Direitos Fundamentais, 2. ed., Tradução de Virgílio Afonso da Silva da $5^{\mathrm{a}}$ edição alemã Theorie der Grundrechte. São Paulo: Malheiros Editores, 2009, p.168-170.

${ }^{306}$ ALEXY, Robert. Teoria dos Direitos Fundamentais, 2. ed., Tradução de Virgílio Afonso da Silva da $5^{\mathrm{a}}$ edição alemã Theorie der Grundrechte. São Paulo: Malheiros Editores, 2009, p. 170.

307 ALEXY, Robert. Teoria dos Direitos Fundamentais, 2. ed., Tradução de Virgílio Afonso da Silva da $5^{\mathrm{a}}$ edição alemã Theorie der Grundrechte. São Paulo: Malheiros Editores, 2009, p. 173 [sem grifo no original]. 308 ALEXY, Robert. Teoria dos Direitos Fundamentais, 2. ed., Tradução de Virgílio Afonso da Silva da $5^{\mathrm{a}}$ edição alemã Theorie der Grundrechte. São Paulo: Malheiros Editores, 2009, p. 173.
} 
Nesse sentido, o modelo defendido por Alexy é equivalente ao denominado "princípio da concordância prática". ${ }^{309}$

Alexy também rechaça a objeção segundo a qual o sopesamento carece de um parâmetro para decisão, implicando, assim, em uma "fórmula vazia", apontado por autores como Christian Pestalozza ${ }^{310}$, por exemplo. Ainda que o sopesamento em si não possa estabelecer um parâmetro que permita uma decisão definitiva dos casos, o "modelo de sopesamento como um todo" oferece sim um critério que, para Alexy, associa a lei de colisão à teoria da argumentação jurídica racional. A lei de colisão aponta o que deve ser fundamentado de forma racional e, por isso, não se pode alegar que ela nada diz e que, portanto, ela seja uma fórmula vazia. ${ }^{311}$

A doutrina alexiana também rechaça a tese segundo a qual os sopesamentos conduziriam a "decisões particulares". Sabendo que decisões de sopesamentos consistem em decisões judiciais, estas nítida e geralmente são proferidas para a solução de casos particulares. Mas, com base na lei do sopesamento, é possível a formulação de uma regra. Portanto, "nada há de inconciliável entre o sopesamento no caso particular e sua universalizabilidade". 312

Ainda em “Teoria dos Direitos Fundamentais", Alexy explica que as questões de direitos fundamentais são questões normativas, e que os enunciados normativos não decorrem diretamente de enunciados empíricos. Quando se trata da mescla de elementos normativos e valorativos, então, surge a questão sobre a procedência dos elementos valorativos e de sua controlabilidade. Não obstante, o modelo de sopesamento baseado na teoria dos princípios é defendido enquanto resposta suficiente para o problema da valoração, "na medida em que vincula a estrutura formal do sopesamento a uma teoria da argumentação jurídica que inclui uma teoria da argumentação prática geral”. 313

\subsection{A IDEIA DE RESTRIÇÃO AOS DIREITOS FUNDAMENTAIS EM ALEXY}

\footnotetext{
${ }^{309}$ ALEXY, Robert. Teoria dos Direitos Fundamentais, 2. ed., Tradução de Virgílio Afonso da Silva da $5^{\text {a }}$ edição alemã Theorie der Grundrechte. São Paulo: Malheiros Editores, 2009, p. 173.

${ }^{310}$ PESTALOZZA, Christian. Kritische Bemerkungen zu Methoden und Prinzipien der Grundrechtsauslegung in der Bundesrepuplik Deutschland. Der Staat 2 (1963), p. 447 apud ALEXY, Robert. Teoria dos Direitos Fundamentais, 2. ed., Tradução de Virgílio Afonso da Silva da $5^{\text {a }}$ edição alemã Theorie der Grundrechte. São Paulo: Malheiros Editores, 2009, p. 173.

${ }^{311}$ ALEXY, Robert. Teoria dos Direitos Fundamentais, 2. ed., Tradução de Virgílio Afonso da Silva da $5^{\mathrm{a}}$ edição alemã Theorie der Grundrechte. São Paulo: Malheiros Editores, 2009, p. 173.

312 ALEXY, Robert. Teoria dos Direitos Fundamentais, 2. ed., Tradução de Virgílio Afonso da Silva da $5^{\text {a }}$ edição alemã Theorie der Grundrechte. São Paulo: Malheiros Editores, 2009, p. 174.

313 ALEXY, Robert. Teoria dos Direitos Fundamentais, 2. ed., Tradução de Virgílio Afonso da Silva da $5^{\text {a }}$ edição alemã Theorie der Grundrechte. São Paulo: Malheiros Editores, 2009, p. 175-176.
} 


\subsubsection{A possibilidade de restrições aos direitos fundamentais}

Se os direitos e as liberdades não são absolutos, menos ainda se pode conferir esse caráter aos limites a que o exercício desses direitos se submete. Ao analisar a posição do Tribunal Constitucional espanhol, Francisco Segado assevera que tanto as normas de libertad como as chamadas normas limitadoras se integram em um único ordenamento inspirado pelos mesmos princípios, "em um regime de concorrência normativa, e não de exclusão".314

Ao admitir como praticamente trivial a ideia de que direitos tenham restrições e que possam ser restringidos, Robert Alexy, em Teoria dos Direitos Fundamentais, reconhece que a problemática do tema restrições a direitos fundamentais gira em torno exatamente da definição do conteúdo e extensão dessas restrições, bem como na distinção entre restrições e outros conceitos, como o de regulamentações, configurações e concretizações. ${ }^{315}$

Robert Alexy elucida que o conceito de restrição a um direito implica a existência de duas coisas: o direito e sua restrição, entre as quais há uma relação de restrição, podendo ser considerada uma relação de tipo especial. Se isso for verdadeiro, há, primeiramente, o direito em si, não restringido, e, em segundo lugar, "aquilo que resta do direito após a ocorrência de uma restrição", ou seja, o direito restringido. Essa é a concepção a que se chama teoria externa. Ressalte-se que, embora essa teoria admita a restringibilidade de direitos, "ela tem que insistir que eles são também concebíveis sem restrições”. Destarte, Alexy aponta que, para a teoria externa, não existe nenhuma relação necessária entre o conceito de direito e o conceito de restrição, por sua vez, sendo que tal relação somente "é criada a partir da exigência externa ao direito em si, de conciliar os direitos de diversos indivíduos, bem como direitos individuais e interesses coletivos". 316

Alexy contrapõe tal perspectiva àquela trazida pela teoria interna, que, de forma completamente diferente, possui como base de sustentação apenas uma coisa: o direito com um determinado conteúdo, em vez de duas coisas - o direito e sua restrição. A ótica da teoria interna substitui o conceito de restrição pelo conceito de limite. ${ }^{317}$ Para o autor, as dúvidas

\footnotetext{
${ }^{314}$ SEGADO, Francisco Fernández. La teoría jurídica de los derechos fundamentales en la doctrina constitucional. In: "Revista Española de Derecho Constitucional", Madrid, n. 39, Septiembre/Diciembre, 1993, p. 236. Disponível em: < http://www.cepc.gob.es/gl/publicaci\%C3\%B3ns/revistas/revistaselectronicas?IDR=6\&IDN=341\&IDA=25145 >. Acesso em 4 nov. 2014.

${ }^{315}$ ALEXY, Robert. Teoria dos Direitos Fundamentais, 2. ed., Tradução de Virgílio Afonso da Silva da $5^{\mathrm{a}}$ edição alemã Theorie der Grundrechte. São Paulo: Malheiros Editores, 2009, p. 276.

316 ALEXY, Robert. Teoria dos Direitos Fundamentais, 2. ed., Tradução de Virgílio Afonso da Silva da $5^{\mathrm{a}}$ edição alemã Theorie der Grundrechte. São Paulo: Malheiros Editores, 2009, p. 277.

${ }^{317}$ Cf. HÄBERLE, Peter, Die Wesensgehaltgarantie, p. 126 apud ALEXY, Robert. Teoria dos Direitos Fundamentais, 2. ed., Tradução de Virgílio Afonso da Silva da $5^{\text {a }}$ edição alemã Theorie der Grundrechte. São Paulo: Malheiros Editores, 2009, p. 277.
} 
acerca dos limites do direito não se enquadram enquanto dúvidas sobre quão extensa pode ser sua restrição, senão dúvidas acerca do seu conteúdo.

$\mathrm{O}$ art. $2^{\circ}, \S 1^{\circ}$ da Constituição alemã consagra que: "Todos têm o direito ao livre desenvolvimento da sua personalidade, desde que não violem os direitos de outros e não atentem contra a ordem constitucional ou a lei moral" ${ }^{318}$. Nas palavras de Alexy, é "atribuível um princípio que exige a maior medida possível de liberdade geral de ação". O direito fundamental que corresponde a esse princípio abarca "algo de excedente", restringível, que não se trata de algo externo ao ordenamento jurídico - como um direito natural, por exemplo -, nem algo localizável abaixo da Constituição, "mas algo que pertence ao acervo de normas constitucionais". Dessa forma, quando se parte do modelo de princípios alexiano, "o que é restringido não é simplesmente um bem protegido pela norma de direito fundamental, mas um direito prima facie garantido por essa norma”. É, portanto, correto falar em restrição a direitos fundamentais no modelo de princípios, que, por sua vez, consagra a teoria externa. ${ }^{319}$

Uma restrição a um bem protegido consiste numa restrição também a uma posição prima facie garantida por um princípio de direito fundamental. Ao responder o questionamento sobre o que são restrições a direitos fundamentais, Robert Alexy afirma: "restrições a direitos fundamentais são normas que restringem uma posição prima facie de direito fundamental", e, acrescenta que tal resposta é dotada de caráter circular, sempre que utiliza o conceito de restrição para definir o conceito de restrição a direito fundamental, oferecendo um "pequeno avanço" ao prelecionar que "as restrições a direitos fundamentais são normas". ${ }^{320}$ Mas por que e como as normas possam ser restrições a direitos fundamentais?

Alexy inicia a resposta afirmando que normas serão restrições a direitos fundamentais tão somente se forem “compatíveis com a Constituição”. Destarte, normas inconstitucionais podem até ter natureza de uma intervenção, mas jamais de uma restrição. ${ }^{321}$ Portanto, a noção de restringibilidade não coaduna com a de incompatibilidade constitucional.

O jusfilósofo alemão aponta que as normas de competência do Estado para criar normas são, geralmente, estabelecidas mediante reservas legais constitucionais, por meio das quais o legislador é autorizado a estabelecer restrições aos direitos fundamentais. Ademais, "a essa competência do legislador corresponde a sujeição do titular de direitos fundamentais".

\footnotetext{
${ }^{318}$ DEUTSCHER BUNDESTAG. Lei Fundamental da República Federal da Alemanha. Disponível em: < https://www.btg-bestellservice.de/pdf/80208000.pdf> . Acesso em 5 out. 2015.

${ }^{319}$ ALEXY, Robert. Teoria dos Direitos Fundamentais, 2. ed., Tradução de Virgílio Afonso da Silva da $5^{\mathrm{a}}$ edição alemã Theorie der Grundrechte. São Paulo: Malheiros Editores, 2009, p. 279.

320 ALEXY, Robert. Teoria dos Direitos Fundamentais, 2. ed., Tradução de Virgílio Afonso da Silva da $5^{\text {a }}$ edição alemã Theorie der Grundrechte. São Paulo: Malheiros Editores, 2009, p. 281.

${ }^{321}$ ALEXY, Robert. Teoria dos Direitos Fundamentais, 2. ed., Tradução de Virgílio Afonso da Silva da $5^{\text {a }}$ edição alemã Theorie der Grundrechte. São Paulo: Malheiros Editores, 2009, p. 281.
} 
Alexy ressalta que somente as competências para a criação de normas que são fundamentadas pelas reservas legais constitucionais - diretamente estabelecidas pela Constituição - e não as competências constitucionais indiretas - edição de decretos ou de atos administrativos, por exemplo -, são capazes de restringir direitos fundamentais. Não se olvide que "à extensão da competência dos órgãos estatais equivale a extensão de sua sujeição às normas criadas de acordo com essa competência".322

Ainda utilizando-se do dever de usar capacete, endereçado aos motociclistas, Alexy observa que, enquanto esse dever não existe, o titular do direito fundamental tem, graças ao princípio da liberdade geral de ação, uma liberdade fundamental prima facie para, como motociclista, usar ou não um capacete. E a partir do momento em que passa a existir o dever, o titular queda-se em uma posição de não-liberdade definitiva, em face do Estado, quanto ao uso ou não do capacete. Portanto, a regra que obriga os motociclistas ao uso do capacete é uma restrição a um direito fundamental, “(...) porque em virtude de sua vigência surge, no lugar da liberdade prima facie, uma não-liberdade definitiva de igual conteúdo". 323

Contudo, o conceito de restrição a direitos fundamentais, em Alexy, vai além das restrições feitas pelas regras, de modo que princípios também podem configurar restrições a direitos fundamentais. O jusfilósofo alemão menciona o assentamento pelo Tribunal Constitucional Federal ${ }^{324}$ de que os "direitos fundamentais de terceiros e outros valores jurídicos de hierarquia constitucional" também podem restringir direitos fundamentais. Nessa esteira, faz-se referência a restrições a direitos fundamentais que possuem caráter de princípios.

No entanto, "princípios restringidores, por si sós, não são capazes de colocar o indivíduo em determinadas posições definitivamente restringidas (não-liberdades, nãodireitos)". Logo, para que uma posição definitiva seja alcançada, faz-se necessário o sopesamento entre o princípio constitucional atingido - posteriormente restringido - e o(s) princípio(s) que o restringe $(\mathrm{m})$ - restringidor. ${ }^{325}$

Princípios colidentes restringem materialmente as possibilidades jurídicas de realização de outros princípios. Deve-se atentar não para a natureza restritiva desses

\footnotetext{
${ }^{322}$ ALEXY, Robert. Teoria dos Direitos Fundamentais, 2. ed., Tradução de Virgílio Afonso da Silva da $5^{\mathrm{a}}$ edição alemã Theorie der Grundrechte. São Paulo: Malheiros Editores, 2009, p. 282.

${ }^{323}$ ALEXY, Robert. Teoria dos Direitos Fundamentais, 2. ed., Tradução de Virgílio Afonso da Silva da $5^{\mathrm{a}}$ edição alemã Theorie der Grundrechte. São Paulo: Malheiros Editores, 2009, p. 283-284. ${ }^{324}$ BVerfGE 28,243 (261).

${ }^{325}$ ALEXY, Robert. Teoria dos Direitos Fundamentais, 2. ed., Tradução de Virgílio Afonso da Silva da $5^{\mathrm{a}}$ edição alemã Theorie der Grundrechte. São Paulo: Malheiros Editores, 2009, p. 284.
} 
princípios, mas para a definição da extensão em que restringem outros princípios. ${ }^{326}$ Assim, um princípio configurará uma restrição a um direito fundamental se houver “(...) casos em que ele é uma razão para que, no lugar de uma liberdade fundamental prima facie ou de um direito fundamental prima facie, surja uma não-liberdade definitiva ou um não-direito definitivo de igual conteúdo".327

Por derradeiro, Alexy aponta uma reformulação conclusiva:

(...) restrições a direitos fundamentais são normas que restringem a realização de princípios de direito fundamental. $\mathrm{O}$ que significa restringir a realização de um princípio de direito fundamental é algo demonstrado de forma paradigmática por meio das normas mandatórias e proibitivas. ${ }^{328}$

Ao tratar das restrições diretamente constitucionais, Alexy assevera que as restrições a direitos fundamentais são ou normas de hierarquia constitucional ou normas infraconstitucionais, cuja criação é autorizada por normas constitucionais. Nesse cenário, ganha importância a distinção entre restrição e cláusula restritiva. Em linhas gerais, o conceito de restrição é inerente à perspectiva do direito, ao passo que o conceito de cláusula restritiva concerne à perspectiva da norma. Uma cláusula restritiva é, portanto, parte de uma norma de direito fundamental completa, “(...) que diz como aquilo que, prima facie, é garantido pelo suporte fático do direito fundamental foi ou pode ser restringido". Ao analisarmos, sob a ótica alexiana, a expressão contida no art. $8^{\circ}, \S 1^{\circ}$, da Constituição alemã, "pacificamente e sem armas" ${ }^{, 32}$, percebemos que a referida cláusula pode ser interpretada como uma "formulação resumida de uma regra", que transforma os direitos prima facie decorrentes do princípio da liberdade de reunião em não-direitos definitivos. Nesse sentido, “(...) a regra expressa pela cláusula restringe a realização de um princípio constitucional”, e foi o próprio constituinte que estabeleceu a restrição definitiva. Assim, a disposição constitucional goza da natureza de regra, contudo, "por trás do nível da regra, o nível do princípio mantém sua importância”. 330

Ao enunciar a delimitação como o principal problema das reservas, Alexy destaca o aspecto material, no que diz respeito à competência atribuída ao legislador para impor

\footnotetext{
${ }^{326}$ ALEXY, Robert. Teoria dos Direitos Fundamentais, 2. ed., Tradução de Virgílio Afonso da Silva da $5^{\text {a }}$ edição alemã Theorie der Grundrechte. São Paulo: Malheiros Editores, 2009, p. 284.

327 ALEXY, Robert. Teoria dos Direitos Fundamentais, 2. ed., Tradução de Virgílio Afonso da Silva da $5^{\text {a }}$ edição alemã Theorie der Grundrechte. São Paulo: Malheiros Editores, 2009, p. 284-285.

${ }^{328}$ ALEXY, Robert. Teoria dos Direitos Fundamentais, 2. ed., Tradução de Virgílio Afonso da Silva da $5^{\mathrm{a}}$ edição alemã Theorie der Grundrechte. São Paulo: Malheiros Editores, 2009, p. 285.

329 O qual prescreve: "Todos os alemães têm o direito de se reunirem pacificamente e sem armas, sem notificação ou autorização prévia”. Cf. DEUTSCHER BUNDESTAG. Lei Fundamental da República Federal da Alemanha. Disponível em: < https://www.btg-bestellservice.de/pdf/80208000.pdf> . Acesso em 5 out. 2015.

${ }^{330}$ ALEXY, Robert. Teoria dos Direitos Fundamentais, 2. ed., Tradução de Virgílio Afonso da Silva da $5^{\text {a }}$ edição alemã Theorie der Grundrechte. São Paulo: Malheiros Editores, 2009, p. 287.
} 
restrições. Ademais, essa competência não sofre limites apenas pelas condições expressas nas reservas qualificadas e pela barreira do conteúdo essencial, mas também pela máxima da proporcionalidade e, por derradeiro, pelo dever de sopesamento. Com isso, ao se associar competência e sopesamento, evita-se que os direitos fundamentais, ao menos no que concerne à parte que esteja além da barreira do conteúdo essencial, fiquem à mercê do legislador e, por derradeiro, tenham seu conteúdo esvaziado. No sopesamento, ao lado do princípio substancial da liberdade de profissão, por exemplo, “(...) o princípio formal da decisão por parte do legislador democraticamente legitimado também pode desempenhar um papel”. O princípio formal que diz respeito à competência decisória do legislador é o fundamento de uma competência legislativa constitutiva para a imposição de restrições, ainda que essa competência seja limitada por princípios substanciais. ${ }^{331}$

Por fim, não é demais apontar o reconhecimento, por Alexy, de que a jurisprudência reiterada do Tribunal Constitucional Federal alemão encontra-se alinhada com as perspectivas teórico-normativas e de fundamentação de sua teoria dos princípios. ${ }^{332}$

\subsubsection{A garantia do conteúdo essencial dos direitos fundamentais}

Após estabelecer, em sua primeira parte, que quando um direito fundamental venha a ser restringido por lei ou em virtude de lei, essa lei tem de ser genérica e não limitada a um caso particular, e que, além disso, a lei deverá citar o direito fundamental em questão, indicando o artigo correspondente, o artigo 19 da Lei Fundamental alema ${ }^{333}$, na segunda parte, dispõe: "Em nenhum caso, um direito fundamental poderá ser violado em sua essência."

Tal disposição, que protege a essência dos direitos fundamentais, corresponde à proteção ao conteúdo essencial desses direitos, o que a doutrina alemã chama de Wesensgehalt.

\footnotetext{
${ }^{331}$ ALEXY, Robert. Teoria dos Direitos Fundamentais, 2. ed., Tradução de Virgílio Afonso da Silva da $5^{\text {a }}$ edição alemã Theorie der Grundrechte. São Paulo: Malheiros Editores, 2009, p.292-295.

332 ALEXY, Robert. Teoria dos Direitos Fundamentais, 2. ed., Tradução de Virgílio Afonso da Silva da $5^{\text {a }}$ edição alemã Theorie der Grundrechte. São Paulo: Malheiros Editores, 2009, p. 131 Cf., por exemplo, BVerfGE 19330 (337); 21, 150 (155); 26, 215 (228); 27, 211 (219); 30, 292 (316).

${ }^{333}$ DEUTSCHER BUNDESTAG. Lei Fundamental da República Federal da Alemanha. Disponível em: < https://www.btg-bestellservice.de/pdf/80208000.pdf> . Acesso em 5 out. 2015.
} 
A partir do artigo 53.1 da Constituição espanhola ${ }^{334}$, que também exige o respeito ao conteúdo essencial dos direitos e liberdades previstos, o professor espanhol Alfonso Parejo entende por conteúdo essencial dos direitos fundamentais:

(...) aquella parte del derecho fundamental que es absolutamente necesaria para que los intereses jurídicamente protegibles, que dan vida al derecho, resulten real, concreta y efectivamente protegidos. Es el núcleo duro que permite reconocer al derecho fundamental como tal, y no como otra cosa. ${ }^{335}$

Destaca o referido autor que se, por um lado, a garantia do conteúdo essencial a determinados direitos fundamentais oferece um aspecto negativo, no sentido de proibição ou limitação ao legislador ordinário, por outro lado, oferece também um aspecto positivo, de "afirmação de um conteúdo imediatamente constitucional nesses direitos". 336

A partir do entendimento assentado do Tribunal Constitucional espanhol, Francisco Segado $^{337}$ aponta a existência de dois critérios de delimitação do conteúdo essencial. O primeiro deles equivale à "natureza jurídica de cada direito", ou seja, ao modo no qual cada direito é concebido. Aqui, o tipo abstrato do direito preexiste conceitualmente o momento legislativo e, assim, pode-se falar em uma "reconhecimento desse tipo abstrato na regulação concreta". A partir dessa ótica, as faculdades ou possibilidades de atuação necessárias para que o direito seja reconhecido como pertinente ao tipo descrito integram o conteúdo essencial de um direito subjetivo. Já a segunda acepção corresponde aos "interesses juridicamente protegidos como núcleo e medula do direito". ${ }^{338}$ Nesse sentido, pode-se indicar a essência do conteúdo do direito para fazer referência àquela parte que é absolutamente necessária para que os interesses juridicamente passíveis de proteção, que dão vida ao direito, resultem reais, concreta e efetivamente protegidos. Desse modo, alerta o autor que se o conteúdo essencial de

\footnotetext{
${ }^{334}$ O qual dispõe: “Los derechos y libertades reconocidos en el Capítulo segundo del presente Título vinculan a todos los poderes públicos. Sólo por ley, que en todo caso deberá respetar su contenido esencial, podrá regularse el ejercicio de tales derechos y libertades, que se tutelarán de acuerdo con lo previsto en el artículo 161, 1, a)." Cf. CONSTITUCIÓN ESPAÑOLA. Disponível em: < https://www.boe.es/buscar/act.php?id=BOEA-1978-31229>. Acesso em 24 nov. 2015.

${ }^{335}$ ALFONSO, Luciano Parejo. El contenido esencial de los derechos fundamentales en la jurisprudencia constitucional. A propósito de la sentencia del Tribunal Constitucional del 8 de abril de 1981. Revista Española de Derecho Constitucional, Vol. I, N³, Madrid, 1981.

${ }^{336}$ ALFONSO, Luciano Parejo. El contenido esencial de los derechos fundamentales en la jurisprudencia constitucional. A propósito de la sentencia del Tribunal Constitucional del 8 de abril de 1981. Revista Española de Derecho Constitucional, Vol. I, N³, Madrid, 1981.

${ }^{337}$ SEGADO, Francisco Fernández. La teoría jurídica de los derechos fundamentales en la doctrina constitucional. In: "Revista Española de Derecho Constitucional", Madrid, n. 39, Septiembre/Diciembre, 1993, p. 242 e ss. Disponível em: < http://www.cepc.gob.es/gl/publicaci\%C3\%B3ns/revistas/revistaselectronicas?IDR=6\&IDN=341\&IDA=25145 >. Acesso em 4 nov. 2014.

${ }^{338}$ SEGADO, Francisco Fernández. La teoría jurídica de los derechos fundamentales en la doctrina constitucional. In: "Revista Española de Derecho Constitucional", Madrid, n. 39, Septiembre/Diciembre, 1993, p. 243. Disponível em: < http://www.cepc.gob.es/gl/publicaci\%C3\%B3ns/revistas/revistaselectronicas?IDR=6\&IDN=341\&IDA=25145 >. Acesso em 4 nov. 2014 .
} 
determinado direito for desconhecido ou extrapolado, esse direito receberá limitações que se resultarão impraticáveis. Por fim, ressalta o autor que esses dois critérios de delimitação do conteúdo essencial dos direitos fundamentais são complementares, podendo ser usados conjuntamente pelo intérprete. ${ }^{339}$

Portanto, aceitar que as normas de direitos fundamentais possam ser restringidas e que essa restringibilidade tem limites também faz parte da natureza dessas normas. Diante de tal reconhecimento, Robert Alexy afirma que “(...) os direitos fundamentais, enquanto tais, são restrições à sua própria restrição e restringibilidade". 340

A partir do "limite adicional" à restrição e à restringibilidade dos direitos fundamentais previsto no art. 19, $\S 2^{\circ}$ da Lei Fundamental alemã, Robert Alexy estabelece uma sistematização das teorias acerca do conteúdo essencial mediante a utilização de dois pares conceituais: conforme o primeiro par, as teorias sobre o conteúdo essencial podem ser diferenciadas segundo relacionem a garantia do conteúdo essencial a uma situação subjetiva ou a uma situação objetiva de regulação constitucional; já o segundo par dispõe a diferenciação entre essas teorias segundo o modo pelo qual elas interpretam essa garantia, ou seja, em um sentido absoluto ou relativo. Independentemente dos referidos critérios, Alexy empenha suas forças em demonstrar os efeitos da teoria dos princípios nesse âmbito. ${ }^{341}$

O Tribunal Constitucional Federal alemão, em decisões seguidas, “(...) sempre associou a garantia do conteúdo essencial a posições individuais”. E, no tocante a esse ponto, Alexy concorda com o tribunal. Isso porque, uma vez que os direitos fundamentais constituem, primariamente, posições individuais, quando a Constituição estabelece algo tão importante quanto uma proibição de afetação do conteúdo essencial dos direitos fundamentais, então, “isso diz respeito no mínimo também a posições de direitos fundamentais individuais". ${ }^{342}$

Vale ressaltar que a natureza dos direitos fundamentais enquanto direitos dos indivíduos caminha, no mínimo, a favor de uma coexistência de uma teoria subjetiva e de uma teoria objetiva.

\footnotetext{
${ }^{339}$ SEGADO, Francisco Fernández. La teoría jurídica de los derechos fundamentales en la doctrina constitucional. In: "Revista Española de Derecho Constitucional", Madrid, n. 39, Septiembre/Diciembre, 1993, p. 243. Disponível em: < http://www.cepc.gob.es/gl/publicaci\%C3\%B3ns/revistas/revistaselectronicas?IDR=6\&IDN=341\&IDA=25145 >. Acesso em 4 nov. 2014.

${ }^{340}$ ALEXY, Robert. Teoria dos Direitos Fundamentais, 2. ed., Tradução de Virgílio Afonso da Silva da $5^{\text {a }}$ edição alemã Theorie der Grundrechte. São Paulo: Malheiros Editores, 2009, p. 296.

${ }^{341}$ ALEXY, Robert. Teoria dos Direitos Fundamentais, 2. ed., Tradução de Virgílio Afonso da Silva da $5^{\mathrm{a}}$ edição alemã Theorie der Grundrechte. São Paulo: Malheiros Editores, 2009, p. 296.

342 ALEXY, Robert. Teoria dos Direitos Fundamentais, 2. ed., Tradução de Virgílio Afonso da Silva da $5^{\text {a }}$ edição alemã Theorie der Grundrechte. São Paulo: Malheiros Editores, 2009, p. 297.
} 
As teorias subjetivas em torno do conteúdo essencial subdividem-se em absolutas ou relativas. Para a teoria relativa, o conteúdo essencial é aquilo que resta após o sopesamento. ${ }^{343}$ Assim, basta que as restrições respeitem a máxima da proporcionalidade, e elas não violarão a garantia do conteúdo essencial - nem mesmo se, no caso concreto, nada restar do direito fundamental. Aqui, “a garantia do conteúdo essencial é reduzida à máxima da proporcionalidade". ${ }^{344}$ Por sua vez, a teoria absoluta apregoa que cada direito fundamental é dotado de um núcleo, fechado para qualquer tipo de intervenção. ${ }^{345}$

A partir de inúmeras manifestações do Tribunal Constitucional Federal alemão, Alexy conclui que aquele parece defender uma teoria absoluta. Na decisão sobre gravações secretas afirma-se, nesse contexto, que:

(...) nem mesmo interesses preponderantes da coletividade podem justificar uma intervenção na esfera nuclear da configuração da vida privada, protegida de forma absoluta; não há lugar para um sopesamento nos termos da máxima da proporcionalidade. ${ }^{346}$

Em outras decisões, o tribunal menciona "um limite absoluto, cuja superação violaria o conteúdo essencial de um direito fundamental" ${ }^{347}$, um "limite extremo" "348 e uma "última área intocável" 349 .

No entanto, existem posições do referido tribunal que podem ser interpretadas nos termos de uma teoria relativa, segundo Alexy. Trata-se, por exemplo, da decisão acerca do bem-estar dos adolescentes e a assistência social ${ }^{350}$, onde o tribunal viu-se disposto a controlar dispositivos como os constantes na Lei de Assistência Social federal que, por sua vez, previam a internação em instituições estatais para pessoas que tivessem uma especial fraqueza de vontade ou um descontrole em seus desejos naturais, ou fossem abandonadas, ou

\footnotetext{
${ }^{343}$ Cf. HÄBERLE, Peter. Die Wesensgehaltgarantie, p. 47 e ss apud ALEXY, Robert. Teoria dos Direitos Fundamentais, 2. ed., Tradução de Virgílio Afonso da Silva da $5^{\text {a }}$ edição alemã Theorie der Grundrechte. São Paulo: Malheiros Editores, 2009, p. 297.

${ }^{344}$ ALEXY, Robert. Teoria dos Direitos Fundamentais, 2. ed., Tradução de Virgílio Afonso da Silva da $5^{\text {a }}$ edição alemã Theorie der Grundrechte. São Paulo: Malheiros Editores, 2009, p. 297-298.

${ }^{345}$ Cf. KRÜGER, Herbert. Der Wesensgehalt der Grundrechte i. S. Des Art. 19 GG, p. 597 e ss apud ALEXY, Robert. Teoria dos Direitos Fundamentais, 2. ed., Tradução de Virgílio Afonso da Silva da $5^{\text {a }}$ edição alemã Theorie der Grundrechte. São Paulo: Malheiros Editores, 2009, p. 298.

${ }^{346}$ BVerfGE 34, 238 (245) apud ALEXY, Robert. Teoria dos Direitos Fundamentais, 2. ed., Tradução de Virgílio Afonso da Silva da $5^{\text {a }}$ edição alemã Theorie der Grundrechte. São Paulo: Malheiros Editores, 2009, p.298.

${ }^{347}$ BVerfGE 16, 194 (201) apud ALEXY, Robert. Teoria dos Direitos Fundamentais, 2. ed., Tradução de Virgílio Afonso da Silva da $5^{\text {a }}$ edição alemã Theorie der Grundrechte. São Paulo: Malheiros Editores, 2009, p.298.

${ }^{348}$ BVerfGE 31, 58 (69) apud ALEXY, Robert. Teoria dos Direitos Fundamentais, 2. ed., Tradução de Virgílio Afonso da Silva da $5^{\text {a }}$ edição alemã Theorie der Grundrechte. São Paulo: Malheiros Editores, 2009, p.298.

${ }^{349}$ BVerfGE 6, 32 (41) apud ALEXY, Robert. Teoria dos Direitos Fundamentais, 2. ed., Tradução de Virgílio Afonso da Silva da $5^{\text {a }}$ edição alemã Theorie der Grundrechte. São Paulo: Malheiros Editores, 2009, p.298.

${ }^{350}$ BVerfGE 22, 180.
} 
corressem o risco de abandono, e para aqueles que pudessem ser ajudados somente no âmbito de tais instituições estatais. $\mathrm{O}$ tribunal entendeu que essas previsões violavam o art. $2^{\circ}, \S 2^{\circ}, 2$ da Constituição alemã, que preleciona: “A liberdade da pessoa é inviolável.” Inicialmente, na fundamentação, estabeleceu-se que "a liberdade da pessoa é um bem jurídico tão elevado que somente pode ser restringida por razões especialmente importantes”. Depois, o tribunal entendeu que a proteção da coletividade e do afetado configuraria uma dessas razões especialmente importantes. Posteriormente, o tribunal estabeleceu que o caso em comento não tratava da proteção da coletividade, nem da proteção do afetado, mas apenas a um tratamento deste. A partir de então, definiu-se o seguinte resultado: tendo em vista que o objetivo de tratar um adulto não é suficiente enquanto razão relevante para a privação da liberdade pessoal, o direito fundamental da liberdade pessoal resta afetado em seu conteúdo essencial. Assim, se não há motivo suficientemente forte para a restrição da liberdade pessoal, se esta for feita, estar-se-á violando o seu núcleo essencial. A internação de adultos para tratamento, portanto, viola o núcleo essencial da liberdade pessoal. Alexy discorre que essa argumentação corresponde exatamente à lei do sopesamento, e que o tribunal utilizou-se também da máxima da proporcionalidade em sentido estrito. Aqui, "uma intervenção intensa somente é justificada se estiver fundamentada com base em razões relevantes". ${ }^{351}$ No caso em tela, percebemos a existência de uma intervenção intensa, mas não há uma razão fundamentadora relevante. A intervenção configura-se, portanto, injustificada. Nesse ínterim, "se o tribunal defendesse uma teoria absoluta, teria ele que partir de alguma posição fixa", como, por exemplo, o direito à não-internação permanente ou por longo período em uma instituição estatal. Ao contrário de pressupor uma tal posição, o tribunal “(...) faz com que a posição abarcada pelo conteúdo essencial dependa das razões relevantes contrárias a uma proteção. Mas essa é exatamente a concepção da teoria relativa". ${ }^{352}$

Vale, aqui, estabelecer um recorte, apontando-se decisão proferida pelo Supremo Tribunal Federal brasileiro, em sede do Habeas Corpus n. 84219/SP, de relatoria do Ministro Marco Aurélio, julgado em 9.11.2004 (Informativo n. 369/STF). ${ }^{353}$ Trata-se da limitação temporal perante o instituto da medida de segurança que, diga-se de passagem, não é dotado de caráter repressivo-punitivo, sendo imposto ao inimputável após sua absolvição, e dotado de natureza preventiva.

\footnotetext{
${ }^{351}$ ALEXY, Robert. Teoria dos Direitos Fundamentais, 2. ed., Tradução de Virgílio Afonso da Silva da $5^{\mathrm{a}}$ edição alemã Theorie der Grundrechte. São Paulo: Malheiros Editores, 2009, p.299.

352 ALEXY, Robert. Teoria dos Direitos Fundamentais, 2. ed., Tradução de Virgílio Afonso da Silva da $5^{\text {a }}$ edição alemã Theorie der Grundrechte. São Paulo: Malheiros Editores, 2009, p.299.

${ }^{353}$ INFORMATIVO STF No 369. HC n. 84219/SP, rel. Min. Marco Aurélio, 9.11.2004. Disponível em: <http://www.stf.jus.br/arquivo/informativo/documento/informativo369.htm>. Acesso em 2 dez. 2015.
} 
No caso em tela, a Turma iniciou o julgamento do habeas corpus que buscava a extinção de medida de segurança aplicada à paciente, diagnosticada como doente mental pela prática do delito de homicídio, cujo cumprimento, em hospital de custódia e tratamento, já ultrapassara trinta anos. Trata-se de impetração contra a decisão do STJ, que indeferira a mesma medida, sob o fundamento de que a lei penal não prevê limite temporal máximo para o cumprimento da medida de segurança, sendo ela apenas condicionada à cessação da periculosidade do agente. Sustenta-se, na espécie, com base nos artigos 75 do Código Penal e 183 da Lei de Execuções Penais, estar a medida de segurança limitada à duração da pena imposta ao réu, e que, mesmo persistindo a doença mental e havendo necessidade de tratamento, após a declaração da extinção da punibilidade, este deve ocorrer em hospital psiquiátrico, cessada a custódia. O então relator Ministro Marco Aurélio, deferiu o HC para que fosse implementada a remoção da paciente para hospital psiquiátrico da rede pública, no que foi acompanhado pelos Ministros Cezar Peluso, Carlos Britto e Eros Grau. Nesse ínterim, o relator “(...) considerou que a garantia constitucional que afasta a possibilidade de ter-se prisão perpétua se aplica à custódia implementada sob o ângulo de medida de segurança"354, levando-se em consideração, ainda, que o limite máximo do tempo de cumprimento das penas privativas de liberdade a que dispõe o art. 75 do CP, e o que estabelece o art. 183 da LEP, segundo o qual o período da medida de segurança é delimitado, ao prever que esta ocorre em substituição da pena, não podendo, dessa forma, ser mais gravosa do que a própria pena. Destarte, a Turma concluiu que, embora o $\S 1^{\circ}$ do art. 97 do CP disponha ser indeterminado o prazo da imposição de medida de segurança, "a interpretação a ser dada a esse preceito deve ser teleológica, sistemática, de modo a não conflitar com as mencionadas previsões legal e constitucional que vedam a possibilidade de prisão perpétua". ${ }^{355}$

À luz do que delineou Alexy, percebemos que uma intervenção tão intensa necessitaria ser justificada por uma forte razão. Contudo, no caso pátrio, não há razão suficientemente importante a ponto de justificar a possibilidade de prisão perpétua.

A leitura que se pode realizar a partir do referido caso é a de que a vedação à prisão perpétua configuraria a medula, o coração, o núcleo essencial do direito fundamental à liberdade, que é violado sempre que a custódia implementada sob o viés da medida de segurança que, por sua vez, não possui caráter punitivo, é mascarada na forma de prisão perpétua pelo sistema judiciário brasileiro.

\footnotetext{
${ }^{354}$ INFORMATIVO STF No 369. HC n. 84219/SP, rel. Min. Marco Aurélio, 9.11.2004. Disponível em: <http://www.stf.jus.br/arquivo/informativo/documento/informativo369.htm>. Acesso em 2 dez. 2015 (grifou-se). ${ }^{355}$ INFORMATIVO STF No 369. HC n. 84219/SP, rel. Min. Marco Aurélio, 9.11.2004. Disponível em: <http://www.stf.jus.br/arquivo/informativo/documento/informativo369.htm>. Acesso em 2 dez. 2015(grifou-se).
} 
Em relação à teoria absoluta, Alexy acredita que ela está, "em certa medida", correta, quando ela afirma que há posições acerca das quais não há razões mais importantes que justifiquem sua restrição. Contudo, diante de tal afirmação, a teoria absoluta está correta “(...) exatamente na medida em que se apoia na teoria relativa". Quando discorre sobre a fundamentação relacionada especificamente ao sopesamento, Alexy entende que, "quanto mais um princípio é restringido, mais ele fica resistente", e que "a força das razões contrapostas tem que crescer de forma sobreproporcional”. Nesse sentido, para o jusfilósofo alemão, "há condições sob as quais é possível afirmar com enorme segurança que nenhum princípio colidente prevalecerá". ${ }^{356}$ Tais condições delineiam o “âmbito nuclear da configuração da vida privada". ${ }^{357}$ Assim, de acordo com Peter Häberle,

“(...) o que é descrito como 'núcleo' intangível da liberdade de ação ou da liberdade contratual é aquele âmbito dentro do qual, sem dúvidas, não há mais nenhum bem jurídico legítimo de igual ou maior valor capaz de limitar direitos fundamentais". ${ }^{358}$

O viés absoluto inerente a essa proteção permanece como uma questão referente à relação entre os princípios envolvidos. Desse modo, “(...) não é possível excluir uma constelação na qual os princípios contrapostos prevaleçam”. Mas a segurança da proteção é de tamanha grandeza que, em condições normais, é possível falar em proteção absoluta. Contudo, não se olvide o fundamento relativo dessa proteção. "A extensão da proteção 'absoluta' depende de relações entre princípios". 359

Não obstante as considerações tecidas por Alexy acerca da decisão, vale citar, ainda, a decisão proferida pelo Tribunal Constitucional Federal alemão que concluiu ser a pena perpétua por homicídio qualificado compatível com a Lei Fundamental. ${ }^{360}$ Entretanto, ressalte-se que o Tribunal estipulou uma série de pressupostos para a sua constitucionalidade $^{361}$, devendo eles serem clara e coerentemente regulados por lei em sentido formal, em homenagem ao princípio do Estado de Direito (Rechtsstaatsprinzip). No presente cenário, “(...) o Tribunal decidiu que a pena perpétua é constitucional desde que permaneça

\footnotetext{
${ }^{356}$ ALEXY, Robert. Teoria dos Direitos Fundamentais, 2. ed., Tradução de Virgílio Afonso da Silva da $5^{\text {a }}$ edição alemã Theorie der Grundrechte. São Paulo: Malheiros Editores, 2009, p.300.

${ }^{357}$ Cf. HABËRLE, Peter. Die Wesensgehaltgarantie, p. 64 apud ALEXY, Robert. Teoria dos Direitos Fundamentais, 2. ed., Tradução de Virgílio Afonso da Silva da $5^{\text {a }}$ edição alemã Theorie der Grundrechte. São Paulo: Malheiros Editores, 2009, p. 300.

${ }^{358}$ Cf. HABËRLE, Peter. Die Wesensgehaltgarantie, p. 64 apud ALEXY, Robert. Teoria dos Direitos

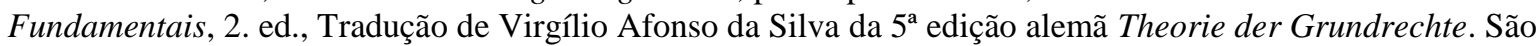
Paulo: Malheiros Editores, 2009, p. 300.

${ }^{359}$ ALEXY, Robert. Teoria dos Direitos Fundamentais, 2. ed., Tradução de Virgílio Afonso da Silva da $5^{\text {a }}$ edição alemã Theorie der Grundrechte. São Paulo: Malheiros Editores, 2009, p.301.

360 BVerfG, 45, 187.

${ }^{361}$ LAMPRECHT, Rolf. Ich gehe bis nach Karlsruhe: Eine Geschichte des Bundesverfassungsgerichts. München: Deutsche Verlags-Anstalt, 2011 apud COSTA NETO, João. Dignidade humana. Visão do Tribunal Constitucional Federal Alemão, do STF e do Tribunal Europeu. São Paulo: Saraiva, 2014, p. 79.
} 
uma chance factível de que o preso, por meio de seu próprio comportamento (conforme requisitos previstos em lei em sentido estrito), volte a ser livre". ${ }^{362}$ Portanto, o Tribunal entendeu que a pena perpétua não afronta o núcleo essencial da liberdade nem o da dignidade humana, desde que observada a possibilidade factível de o bom comportamento do preso vir a libertá-lo.

Finalmente, Alexy chega à conclusão de que a garantia do conteúdo essencial prevista no art. $19, \S 2^{\circ}$, da Lei Fundamental alemã, não cria nenhum limite adicional à restringibilidade dos direitos fundamentais, em relação à máxima da proporcionalidade. Assim, "visto que ela é equivalente a uma parte da proporcionalidade, fornece ela mais uma razão a favor da vigência dessa máxima". 363

Assim, percebemos em Alexy a adoção de uma teoria relativa de proteção ao núcleo essencial dos direitos fundamentais, uma vez que a garantia ao núcleo essencial convive intimamente com a máxima da proporcionalidade.

\section{POR QUE RECHAÇAR A IDEIA DO DIREITO ENQUANTO MÉTODO?}

Não obstante a teoria de Robert Alexy ainda se encontre em uso pela teoria constitucional contemporânea brasileira ${ }^{364}$, cabe, aqui, apontar os seus erros.

Jürgen Habermas e Klaus Günther teceram uma crítica à concepção alexiana de que princípios são mandamentos de otimização, suscetíveis de ponderação, tendo em vista que ela confundiria a argumentação deontológica - inerente à esfera de aplicação judicial do Direito com a axiológica. Para os autores, no campo do Direito, os juízos axiológicos caberiam exclusivamente ao legislador, quando da elaboração das normas jurídicas, e não ao juiz, por ocasião de sua aplicação. Sob tal ótica, a técnica da ponderação de princípios seria incompatível com a separação de poderes e com o Estado Democrático de Direito, acarretando insegurança jurídica e arbítrio judicial. ${ }^{365}$

\footnotetext{
${ }^{362}$ COSTA NETO, João. Dignidade humana. Visão do Tribunal Constitucional Federal Alemão, do STF e do Tribunal Europeu. São Paulo: Saraiva, 2014, p. 79.

363 ALEXY, Robert. Teoria dos Direitos Fundamentais, 2. ed., Tradução de Virgílio Afonso da Silva da $5^{\mathrm{a}}$ edição alemã Theorie der Grundrechte. São Paulo: Malheiros Editores, 2009, p.301.

364 Adotam essa posição autores como: BARROSO, Luís Roberto. A nova interpretação constitucional: ponderação, direitos fundamentais e relações privadas. Rio de Janeiro: Renovar, 2003, p. 327- 378; PEREIRA, Jane Reis Gonçalves. Interpretação constitucional e direitos fundamentais. Rio de Janeiro: Renovar, 2006, p. 75127; SILVA, Virgílio Afonso da. Direitos fundamentais: conteúdo essencial, restrições e eficácia. São Paulo: Malheiros, 2009, p. 43-64.

${ }^{365}$ Vide: HABERMAS, Jürgen. Direito e democracia: entre facticidade e validade, vol. I, 2.ed., tradução: Flávio Beno Siebeneichler. Rio de Janeiro: Tempo Brasileiro, 2012, p. 314-323; e Günther, Klaus. Teoria da argumentação no direito e na moral: justificação e aplicação. Tradução de Cláudio Molz. São Paulo: Landy, 2004, p. 349-414.
} 
Assim, a interpretação dos princípios como mandamentos de otimização, de maior ou menor intensidade, que vem ao encontro do discurso "frouxo" da ponderação de valores, é alvo de crítica em Habermas, para o qual:

\begin{abstract}
Quando princípios colocam um valor, que deve ser realizado de modo otimizado e quando a medida de preenchimento desse mandamento de otimização não pode ser extraído da própria norma, a aplicação de tais princípios no quadro do que é faticamente possível impõe uma ponderação orientada por um fim. E, uma vez que nenhum valor pode pretender uma primazia incondicional perante outros valores, a interpretação ponderada do direito vigente se transforma numa realização concretizadora de valores, referida a casos: ${ }^{366}$ "Concretização é o preenchimento criativo, apenas conforme à orientação ou ao princípio, de algo determinado, que no mais continua aberto, necessitando da determinação complementadora para se transformar numa norma exequível. Hans Huber já chamou há muito tempo a atenção para o fato de que a necessidade de concretização dos direitos fundamentais - entendidos como normas de princípio - que resulta de sua universal validade, amplidão e indeterminação, não pode ser confundida com necessidade de interpretação ... E é preciso acrescentar, por motivo de clareza, que essa legislação referida a casos, uma vez que surge como interpretação da constituição, atinge o nivel de constituição, representando, pois, legislação constitucional ${ }^{, 367}$.
\end{abstract}

A partir dessa citação, Habermas assevera que Böckenförde toma a autocompreensão metodológica do Tribunal Constitucional Federal alemão ao pé da letra, quando, na verdade, o verdadeiro problema reside na adaptação de princípios do direito a valores.

As normas possuem validade deontológica, e isso implica, conforme a compreensão habermasiana, no sentido absoluto de uma obrigação incondicional e universal - "o que deve ser pretende ser igual para todos". Portanto, sob a ótica das normas, é possível decidir o que deve ser feito; ao passo que, à luz dos valores, é possível saber qual comportamento é recomendável. No âmbito das normas, a aplicação correta dar-se-á, para Habermas, “quando partimos de um sistema de normas válidas, e a ação é igualmente boa para todos". Por outro lado, na dimensão dos valores, típica para uma determinada cultura ou forma de vida, será considerado "correto" o comportamento que, em sua totalidade e a longo prazo for considerado "bom para nós". 368

Nesse ínterim, quando se trata de princípios ou de bens jurídicos, a diferença é comumente deixada de lado. Não obstante,

(...) sem prejuízo dessa limitação fática da esfera de validade, quando Dworkin entende os direitos fundamentais como princípios deontológicos do direito e Alexy os considera como bens otimizáveis do direito, não estão se referindo à mesma coisa. (...) A transformação conceitual de direitos e valores fundamentais significa

\footnotetext{
${ }^{366}$ HABERMAS, Jürgen. Direito e democracia: entre facticidade e validade, vol. I, 2.ed., tradução: Flávio Beno Siebeneichler. Rio de Janeiro: Tempo Brasileiro, 2012, p. 315-316.

${ }^{367}$ BÖKENFÖRDE, 1991, 186s apud HABERMAS, Jürgen. Direito e democracia: entre facticidade e validade, vol. I, 2.ed., tradução: Flávio Beno Siebeneichler. Rio de Janeiro: Tempo Brasileiro, 2012, p. 315-316.

${ }^{368}$ HABERMAS, Jürgen. Direito e democracia: entre facticidade e validade, vol. I, 2.ed., tradução: Flávio Beno Siebeneichler. Rio de Janeiro: Tempo Brasileiro, 2012, p. 317.
} 
um mascaramento teleológico de direitos que encobre a circunstância de que, no contexto de fundamentação, normas e valores assumem papéis diferentes na lógica da argumentação. ${ }^{369}$

Habermas defende que o sentido deontológico dos direitos fundamentais impede que eles caiam em uma análise de custos e vantagens. Assim, "é preciso estabelecer um nexo racional entre a norma pertinente e as normas que passam para o pano de fundo, de tal modo que a coerência do sistema de regras permaneça intocada em seu todo". Em vez de serem as normas mandamentos de otimização, elas serão ou adequadas, ou não-adequadas. E, adequação, nesse sentido, significa "a validade de um juízo deduzido de uma norma válida, através do qual a norma subjacente é satisfeita". Portanto, conclui o jurista que "uma jurisprudência orientada por princípios precisa definir qual pretensão e qual ação deve ser exigida num determinado conflito", ao invés de "arbitrar sobre o equilíbrio de bens ou sobre o relacionamento entre os valores", 370

Não se olvide que autores como Habermas e Günther reconhecem que as hipóteses envolvendo colisões entre princípios não logram ser solucionadas tão somente com recurso à lógica formal. Nesses casos, o papel do juiz intérprete deve ser o de considerar todas as circunstâncias do caso, bem como as demais normas do sistema jurídico. E é a partir desse exame integral do contexto fático e normativo que se define qual dos princípios prima facie aplicáveis deverá efetivamente incidir, por ser ele o mais adequado à hipótese. ${ }^{371}$ Desse modo, contrariamente ao que sustenta Alexy, não se trata de ponderar ou de otimizar princípios, a fim de lhes conferir uma aplicação gradual, mas de verificar, atentando-se a "todas as especificidades e variáveis envolvidas na situação" qual o princípio mais adequado ao caso. Esse princípio deverá ser integralmente cumprido, ao passo que o outro que estava com ele concorrendo, será totalmente afastado da solução do problema. ${ }^{372}$

Para Daniel Sarmento e Cláudio Pereira, os princípios, sob tal perspectiva, "seriam normas cuja aplicação abrir-se-ia a múltiplas considerações relativas à sua adequação às especificidades de cada caso (juízo de adequação)",373. Por outro lado, as regras, ao terem sua incidência avaliada pelo intérprete a determinado caso, apresentariam apenas os elementos já

\footnotetext{
${ }^{369}$ HABERMAS, Jürgen. Direito e democracia: entre facticidade e validade, vol. I, 2.ed., tradução: Flávio Beno Siebeneichler. Rio de Janeiro: Tempo Brasileiro, 2012, p. 317-318.

${ }^{370}$ HABERMAS, Jürgen. Direito e democracia: entre facticidade e validade, vol. I, 2.ed., tradução: Flávio Beno Siebeneichler. Rio de Janeiro: Tempo Brasileiro, 2012, p. 322-323.

${ }^{371}$ SOUZA NETO, Cláudio Pereira de; SARMENTO, Daniel. Direito Constitucional: Teoria, história e métodos de trabalho. $2^{\mathrm{a}}$ ed. Belo Horizonte: Fórum, 2014, p. 385.

${ }^{372}$ SOUZA NETO, Cláudio Pereira de; SARMENTO, Daniel. Direito Constitucional: Teoria, história e métodos de trabalho. $2^{\text {a }}$ ed. Belo Horizonte: Fórum, 2014, p. 385-386.

${ }^{373}$ SOUZA NETO, Cláudio Pereira de; SARMENTO, Daniel. Direito Constitucional: Teoria, história e métodos de trabalho. $2^{\mathrm{a}}$ ed. Belo Horizonte: Fórum, 2014, p. 386.
} 
definidos pelo legislador, "excluindo da sua análise todas as outras possíveis dimensões do problema". 374

Uma vez que o procedimento de elaboração normativa tenha ocorrido democraticamente e que tenha levado em consideração, de forma imparcial, o interesse do todos os envolvidos, a escolha legislativa de positivação de normas jurídicas na forma de regras - e não de princípios -, já passou pelo juízo de valor sobre quais fatores deveriam ou não ser considerados pelo intérprete para deflagrar a aplicação normativa, devendo, portanto, essa escolha, ser considerada válida e admissível. ${ }^{375}$

Assim, verificamos em Habermas um ataque à jurisprudência de valores em geral e à técnica do sopesamento de princípios em especial enquanto autocompreensão equivocada da atividade da jurisdição constitucional. ${ }^{376}$

Diante do problema da racionalidade da prestação jurisdicional, ou seja, da aplicação de um direito contingente a ser realizado de maneira internamente consistente e externamente fundamentada, de forma racional, e que seja capaz de garantir, por conseguinte, a certeza do Direito e a correção ${ }^{377}$, a teoria de Ronald Dworkin pode ser bem vista, enquanto tentativa adequada de apontar como a decisão judicial pode cumprir, a um só tempo, as exigências de segurança jurídica e aceitabilidade racional. ${ }^{378}$

Sob a perspectiva dworkineana, que será posteriormente aprofundada neste estudo, o Direito moderno não é um simples instrumento a serviço de objetivos do poder político, como quer o realismo, mas indica um momento: O momento da indisponibilidade, que se afirma no sentido de validade deontológica
dos direitos, aponta, ao invés disso, para uma averiguação racional - orientada por
princípios - das "únicas decisões corretas". No entanto, como esses princípios não
são topoi historicamente comprovados, que podem ser extraídos exclusivamente do
contexto tradicional de uma comunidade ética, como pretende a hermenêutica
jurídica, a prática de interpretação necessita de um ponto de referência que
ultrapassa as tradições jurídicas consuetudinárias. Dworkin esclarece esse ponto de
referência da razão prática de dois modos: metodicamente, lançando mão do
processo da interpretação construtiva; e, conteudisticamente, através do postulado de

\footnotetext{
${ }^{374}$ GÜNTHER, Klaus. Teoria da argumentação no direito e na moral: justificação e aplicação. Tradução de Cláudio Molz. São Paulo: Landy, 2004, p. 392.

${ }^{375}$ SOUZA NETO, Cláudio Pereira de; SARMENTO, Daniel. Direito Constitucional: Teoria, história e métodos de trabalho. $2^{\text {a }}$ ed. Belo Horizonte: Fórum, 2014, p. 386.

${ }^{376}$ Cf. HABERMAS, Jürgen. Direito e Democracia: entre facticidade e validade. v.1. Rio de Janeiro: Tempo Brasileiro, 1997.

${ }^{377}$ HABERMAS, Jürgen. Direito e Democracia: entre facticidade e validade. v.1. Rio de Janeiro: Tempo Brasileiro, 1997, p. 247.

${ }^{378}$ MARQUES, Raphael Peixoto de Paula. Teoria dos direitos fundamentais e argumentação jurídica: reconstruindo o debate entre Jürgen Habermas e Robert Alexy. Disponível em: < www.agu.gov.br/page/download/index/id/13836048>. Acesso em 20 out.
} 
uma teoria do direito que reconstrói racionalmente e conceitualiza o direito vigente. $^{379}$

Tendo como ponto de partida a constatação de que as decisões judiciais envolvem não apenas a aplicação de regras, mas também de princípios, resta nítida a possibilidade de existência das colisões, sem que isso implique qualquer incoerência profunda do sistema jurídico. $^{380}$ De acordo com a teoria habermasiana, todas as normas vigentes são indeterminadas com relação à sua situação, o que pressupõe conexões adicionais no caso concreto. $^{381}$ Uma norma válida somente fundamenta um juízo singular correto quando é possível concluir que ela é a única apropriada para reger o caso concreto. Portanto,

\begin{abstract}
A aplicação imparcial de uma norma fecha a lacuna que ficara aberta quando da sua fundamentação imparcial, devido à imprevisibilidade das situações futuras. Em discursos de aplicação, não se trata da validade e sim da relação adequada da norma à situação. [...] Se entendêssemos a "colisão" das normas ponderadas no processo de interpretação como uma "contradição" no sistema de normas, estaríamos confundindo a "validade" de uma norma, justificada sob o aspecto da fundamentação, com a "adequação" de uma norma que é examinada sob o aspecto da aplicação. ${ }^{382}$
\end{abstract}

Ao estreitar a relação entre princípios e valores, apontando que princípios podem ser tratados como valores, "Alexy dilui o código binário do Direito e a pretensão de correção das normas". ${ }^{383}$ Sob a luz da compreensão habermasiana, aqui, não se trata de uma discussão meramente semântica, tendo em vista que é justamente esse código que assegura aos direitos fundamentais a designação de trunfos, de argumentos de princípios, que têm prioridade sobre argumentos de política ou utilitaristas. Para Habermas,

[...] o direito se apresenta diante de seus destinatários, assim como antes, munido de uma reivindicação de validação que exclui uma pesagem dos direitos segundo o modelo da ponderação de bens jurídicos precedentes ou menos importantes. A maneira de avaliar nossos valores e a maneira de decidir o que é bom para nós e o que há de melhor caso a caso, tudo isso se altera de um dia para o outro. Tão logo passássemos a considerar o princípio da igualdade jurídica meramente como um bem entre outros, os direitos individuais poderiam ser sacrificados caso a caso em favor de fins coletivos. ${ }^{384}$

\footnotetext{
${ }^{379}$ HABERMAS, Jürgen. Direito e Democracia: entre facticidade e validade. v.1. Rio de Janeiro: Tempo Brasileiro, 1997, p. 259-260.

${ }^{380}$ MARQUES, Raphael Peixoto de Paula. Teoria dos direitos fundamentais e argumentação jurídica: reconstruindo o debate entre Jürgen Habermas e Robert Alexy. Disponível em: < www.agu.gov.br/page/download/index/id/13836048>. Acesso em 20 out.

${ }^{381}$ MARQUES, Raphael Peixoto de Paula. Teoria dos direitos fundamentais e argumentação jurídica: reconstruindo o debate entre Jürgen Habermas e Robert Alexy. Disponível em: < www.agu.gov.br/page/download/index/id/13836048>. Acesso em 20 out.

382 HABERMAS, Jürgen. Direito e Democracia: entre facticidade e validade. v.1. Rio de Janeiro: Tempo Brasileiro, 1997, p. 269-270.

${ }^{383}$ MARQUES, Raphael Peixoto de Paula. Teoria dos direitos fundamentais e argumentação jurídica: reconstruindo o debate entre Jürgen Habermas e Robert Alexy. Disponível em: < www.agu.gov.br/page/download/index/id/13836048>. Acesso em 20 out.

${ }^{384}$ HABERMAS, Jürgen. Reply to symposium participants - Benjamin N. Cardoso School of Law. Cardozo Law Review, v. 17, março de 1996.
} 
A perspectiva axiológica dos direitos e o uso da técnica da ponderação, em Alexy, acaba por tratar o Direito e a Constituição enquanto uma ordem concreta de valores, passíveis de gradação em casos de conflito. Dworkin nos ensina que não há problema em tratar os princípios e o Direito como um todo como valor. O que não devemos é resvalar-nos na ideia de que valores entrem em conflito, uma vez que é possível uma teoria que unifique os valores em um todo coerente, o que delineia a ideia de integridade no direito, a Justiça de ouriços.

Habermas assevera que tanto as regras como os princípios "são mandamentos (...) cuja validade deontológica exprime o caráter de uma obrigação". Nesse sentido, essa distinção não se confunde com a determinação de objetivos. Princípios e regras "não podem ser entendidos como preceitos de otimização - conforme é sugerido pela 'ponderação de bens' nas demais doutrinas metodológicas -, porque isso suprimiria o seu sentido de validade deontológica". ${ }^{385}$

O que nos resta clara é a pretensão de Alexy de controlar metodologicamente a indeterminação estrutural do Direito e a consequente eliminação da tensão imanente ao Direito que, para Habermas, se manifesta na jurisdição enquanto tensão entre segurança jurídica e correção das decisões ${ }^{386}$.

Ao apresentar a sua teoria baseada em um método, com o intento de alcançar a racionalidade, Alexy não percebe que o método não implica a garantia de certeza, de inefabilidade, de segurança. A redução do Direito ao método heurístico somente evidencia uma verdadeira crença - exagerada - no poder das normas gerais e abstratas.

Até mesmo em artigos recentes, como em "Balancing, constitutional review, and representation", Alexy ${ }^{387}$ mantém sua argumentação, apontando que o sopesamento “(...) parte de uma estrutura complexa de sub-regras e que busca atingir um resultado que encontra respaldo, até mesmo, em uma fórmula matemática".388

Por outro lado, ao invés de tentar controlar a indeterminação do Direito, as propostas de Habermas, de Klaus Günther ${ }^{389}$ e de Ronald Dworkin complementam-se, na medida em que possuem vários pontos de encontro. Eles buscam evidenciar a especificidade do discurso

\footnotetext{
${ }^{385}$ HABERMAS, Jürgen. Direito e Democracia: entre facticidade e validade. v.1. Rio de Janeiro: Tempo Brasileiro, 1997, p. 258.

${ }^{386}$ HABERMAS, Jürgen. Direito e Democracia: entre facticidade e validade. v.1. Rio de Janeiro: Tempo Brasileiro, 1997, p. 245.

${ }^{387}$ ALEXY, Robert. Balancing, constitutional review, and representation. International Journal of constitutional Law. Oxford University Press e New York University School of Law, 2005. v. 3. n. 4, p. 573.

${ }^{388}$ PEDRON, Flávio Quinaud. A contribuição e os limites da teoria de Klaus Günther: A distinção entre discursos de justificação e discursos de aplicação como fundamento para uma reconstrução da função jurisdicional. Disponível em: <http://dspace/xmlui/bitstream/item/6243/Biblioteca\%20Digital\%20$\% 20$ Editora\%20F\%C3\%B3rum.pdf?sequence=1>. Acesso em 10 out. 2015.

${ }^{389}$ Cf. GÜNTHER, Klaus. Uma concepção normativa de coerência para uma teoria discursiva da argumentação jurídica. Cadernos de Filosofia Alemã, n. 06, São Paulo, 2000.
} 
de aplicação, é dizer, a irrepetibilidade e a unicidade de cada caso concreto de aplicação, o que exige do intérprete a sensibilidade para levar em conta todas as circunstâncias do caso, rejeitando, com isso, as pretensões abusivas baseadas em normas gerais e abstratas, ao passo que assegure, paralelamente, a certeza do direito e a justiça da decisão.

Portanto, a conclusão a que chegamos é a de que a compreensão principiológica de Alexy não se configura adequada ao atual paradigma do Estado Democrático de Direito, que pressupõe um esforço interpretativo sensível e coerente, direcionado à garantia dos trunfos clamados pelo paradigma moderno.

\title{
3. DWORKIN: ORDENAMENTO PRINCIPIOLÓGICO
}

\subsection{COMUNIDADE DE PRINCÍPIOS E INTEGRIDADE DO DIREITO}

Superando o questionamento acerca do que é a Constituição, Ronald Dworkin prefere demonstrar o que ela constitui. No célebre debate com Posner acerca do tema dos direitos implícitos, Dworkin afirma não ser partidário da distinção entre direitos constitucionais expressos (enumerated rights) e implícitos (unenumerated rights). Ele observa que não obstante a linguagem da Constituição (do Bill of Rights) utilize no mais das vezes os termos mais abstratos possíveis dos padrões de correção política (political morality), ela pode parecer, em alguns contextos, integralmente preocupada com os procedimentos. Nesse sentido, Dworkin ressalta que:

\begin{abstract}
Legal history has rejected that narrow interpretation, however, and once we understand the constitutional provisions to be substantive as well as procedural, their scope is breathtaking. For then, the Bill of Rights orders nothing less than that government treat everyone subject to its dominion with equal concern and respect, and that it not infringe their most basic freedoms, those liberties essential, as one prominent jurist put it, to the very idea of "ordered liberty". 390
\end{abstract}

Ao observar a declaração de direitos (Bill of Rights), Dworkin afirma que ela parece conferir ao juiz incríveis poderes, e que a cultura jurídica americana insiste no pensamento de que os juízes - inclusive os da Suprema Corte - possuem a palavra final acerca da interpretação adequada da Constituição. Uma vez que os grandes dispositivos constitucionais determinam simplesmente que o Estado demonstre igual consideração e respeito pelas liberdades fundamentais - sem especificar com maiores detalhes o que isso significa e requer

\footnotetext{
${ }^{390}$ DWORKIN, Ronald. The concept of non enumerated rights. In: University of Chicago Law Review. Vol. 59, 1992, p. 382.
} 
- então, "it falls to judges to declare what equal concern really does require and what the basic liberties really are". ${ }^{391}$

Em seguida, acrescenta Dworkin:

O Bill of Rights é constituído (...), por princípios universais, amplos e abstratos, de correção política (political morality), que conjuntamente envolvem, de forma excepcionalmente abstrata, todas as dimensões de correção política (political morality) que em nossa cultura política possa fundar um direito constitucional individual. A questão-chave na aplicação desses princípios abstratos às controvérsias políticas particulares não é da ordem da referência, mas da interpretação, que é coisa bem distinta. ${ }^{392}$

Ademais, Dworkin confere destaque ao caráter interpretativo do argumento, que exclui qualquer limite semântico que a distinção impõe. Assim, "a interpretação jurídica é essencialmente holística, ainda quando o alvo aparente da interpretação seja um determinado dispositivo ou expressão e não o documento como um todo". ${ }^{393}$ Nesse sentido, Dworkin alerta-nos para a não existência de uma fórmula capaz de garantir que todos os juízes alcançarão a mesma resposta nos casos constitucionais cruciais, novos ou complexos. Assim, é nítido o alerta de Dworkin segundo o qual a recorribilidade a fórmulas não é garantia de defesa contra más decisões - "No formula can protect us (...)".394

Resta-nos, portanto, o seguinte apelo:

Nor should we waste any more time with the silly indulgence of American legal academic life: the philosophically juvenile claim that, since no such formula exists, no one conception of constitutional equality or liberty is any better than another, and adjudication is only power or visceral response. ${ }^{395}$

Com isso, o jusfilósofo norte-americano aponta que devemos insistir, ao invés de buscarmos o falso amparo de uma fórmula, em um "princípio do genuíno poder" (principle of genuine power): a ideia, instinto presente no próprio conceito de Direito, segundo a qual quaisquer que sejam as suas visões de justiça e de correção normativa (fairness), os juízes

\footnotetext{
${ }^{391}$ DWORKIN, Ronald. The concept of non enumerated rights. In: University of Chicago Law Review. Vol. 59, 1992, p. 383.

${ }^{392}$ DWORKIN, Ronald. The concept of non enumerated rights. In: University of Chicago Law Review. Vol. 59, 1992, p. 384 e ss.

${ }^{393}$ DWORKIN, Ronald. The concept of non enumerated rights. In: University of Chicago Law Review. Vol. 59, 1992, p. 384 e ss.

${ }^{394}$ DWORKIN, Ronald. The concept of non enumerated rights. In: University of Chicago Law Review. Vol. 59, 1992 , p. 393.

${ }^{395}$ DWORKIN, Ronald. The concept of non enumerated rights. In: University of Chicago Law Review. Vol. 59, 1992, p. 393. Ver também: DWORKIN, Ronald. Pragmatism, Right Answers and true Banality. In: Michael

Brint, ed., Pragmatism and Law (forthcoming 1992).
} 
devem também aceitar o limite independente e superior da integridade (an independent and superior constraint of integrity). ${ }^{396}$

Por derradeiro, ao apontar as dimensões da integridade, Dworkin destaca que ela insiste que a decisão judicial seja uma questão de princípio, e não um compromisso ou uma estratégia de acomodação política; em segundo lugar, a integridade restringe (holds) verticalmente, sendo que um juiz que pretenda que um determinado direito de liberdade seja fundamental deve demonstrar que essa pretensão é consistente com as estruturas centrais de nossa organização constitucional. Em terceiro lugar, a integridade limita (holds) horizontalmente na medida em que um juiz que adote um princípio deve dar pleno peso a esse princípio em outros casos que ele decida. ${ }^{397}$

Ao negar a garantia de decisões uniformes, Dworkin elucida que a proteção da integridade é direcionada ao princípio, não à uniformidade. Finalmente, nas palavras de Dworkin: "We are governed not by a list but by an ideal, and controversy is therefore at the heart of our story. We are envied for our constitutional adventure, and increasingly imitated, throughout the democratic world". 398

A partir do referido debate, podemos compreender que Dworkin apregoa que a Constituição constitui uma comunidade de princípios, é dizer, uma comunidade fundada sobre princípios. Essa comunidade é calcada no reconhecimento recíproco da igualdade e da liberdade de todos e cada um de seus membros. Esse cenário é figurado pela recepção do abstrato conteúdo moral pelo Direito que, por sua vez, confere maior densidade e concretude a esse conteúdo, que o torna legítimo. Esse conteúdo moral, então, passa a ser incorporado ao Direito enquanto direitos fundamentais e princípios constitucionais. ${ }^{399}$

Portanto, faz-se necessário destacar, no presente cenário, que o Direito é concebido como um sistema aberto de princípios e regras, ambos dotados de natureza normativa, cuja aplicação demanda adequabilidade à unicidade e irrepetibilidade das particularidades de cada caso concreto. É neste momento quando, observado o esquema coerente da comunidade de princípios, o texto normativo logra alcançar o seu verdadeiro sentido. Vale lembrar que a coerência indicada pela comunidade de princípios não implica na ideia de que direitos não

\footnotetext{
${ }^{396}$ DWORKIN, Ronald. The concept of non enumerated rights. In: University of Chicago Law Review. Vol. 59, 1992 , p. 393.

${ }^{397}$ DWORKIN, Ronald. The concept of non enumerated rights. In: University of Chicago Law Review. Vol. 59, 1992, p. 393-394.

${ }^{398}$ DWORKIN, Ronald. The concept of non enumerated rights. In: University of Chicago Law Review. Vol. 59, 1992 , p. 394.

${ }^{399}$ NETTO, Menelick de Carvalho; SCOTTI, Guilherme. Os Direitos Fundamentais e a (in)certeza do Direito: a produtividade das tensões principiológicas e a superação do sistema de regras. Editora Fórum, 2011, p. 71-72.
} 
entrem em conflito. Pelo contrário, as tensões são inerentes e necessárias ao cenário jurídicosocial-democrático moderno.

Os sentidos da integridade, na teoria de Dworkin, podem ser resumidos pela seguinte constatação:

\begin{abstract}
A integridade do Direito significa, a um só tempo, a densificação vivencial do ideal da comunidade de princípio, ou seja, uma comunidade em que seus membros se reconhecem reciprocamente como livres e iguais e como co-autores das leis que fizeram para reger efetivamente a sua vida cotidiana em comum, bem como, em uma dimensão diacrônica, a leitura à melhor luz da sua história institucional como um processo de aprendizado em que cada geração busca, da melhor forma que pode, vivenciar esse ideal. Desse segundo sentido decorre a metáfora do romance em cadeia. ${ }^{400}$
\end{abstract}

\title{
3.2 QUAL É O AJUSTE POLÍTICO EXIGIDO PELA JUSTIÇA?
}

\subsubsection{Quando os direitos são levados a sério}

Baseado na constatação de que a reivindicação de um direito consiste, no sentido restrito, num "tipo de juízo sobre o que é certo ou errado que os Estados façam”, Dworkin baseia-se em uma teoria moderada de direitos contra o Estado, onde um homem possui um direito contra o Estado, "se pudermos mostrar que este comete um erro ao tratá-lo de uma determinada maneira, ainda que o faça tendo em vista o interesse geral". 401

Ao encararmos os direitos de tal forma, podemos afirmar, despidos de estranheza, "que os direitos podem variar em força e características de um caso para outro e de um momento a outro na história". ${ }^{402}$ Assim, o contexto pertencente ao paradigma vivido por cada momento permite a ressignificação da importância de cada direito.

O direito constitucional, na visão de Dworkin, não poderá realizar um verdadeiro progresso "enquanto não isolar o problema dos direitos contra o Estado e tornar esse problema parte de sua própria agenda", o que vale como um argumento em prol de uma "fusão do direito constitucional e da teoria moral". Sem o objetivo de adentrarmos na teoria moral, basta esclarecer que a compreensibilidade de que os juristas se "contaminem", no sentido de se influenciarem pelo diálogo da filosofia moral, especialmente pelos filósofos que

\footnotetext{
${ }^{400}$ NETTO, Menelick de Carvalho; SCOTTI, Guilherme. Os Direitos Fundamentais e a (in)certeza do Direito: a produtividade das tensões principiológicas e a superação do sistema de regras. Editora Fórum, 2011, p. 27.

${ }^{401}$ DWORKIN, Ronald. Levando os direitos a sério. Tradução: Nelson Boeira, 3.ed. São Paulo: Editora WMF Martins Fontes, 2010, p. 218.

${ }^{402}$ DWORKIN, Ronald. Levando os direitos a sério. Tradução: Nelson Boeira, 3.ed. São Paulo: Editora WMF Martins Fontes, 2010, p. 218.
} 
discorrem sobre direitos, "porque as nuanças fantasmagóricas desse conceito assombram o cemitério da razão". 403

Vale esclarecer que a teoria moderada dos direitos de Dworkin pressupõe que os cidadãos ${ }^{404}$ possuem certos direitos fundamentais contra o Estado. Esses direitos eram direitos morais, que foram transformados em direitos jurídicos pela Constituição. ${ }^{405}$

Assim, Dworkin trabalha com o conceito de direitos contra o Estado ${ }^{406}$, sendo que este comete um erro ao restringir um direito que os cidadãos têm contra ele. Nesse sentido, "um direito contra o Estado deve ser um direito de fazer algo mesmo quando a maioria considera errado fazer tal coisa, ainda que a maioria fique prejudicada em razão disso". 407

Os direitos constitucionais que Dworkin considera direitos fundamentais, como o direito à liberdade de expressão, configuram direitos, no sentido forte, contra o Estado. 408 Nesse sentido, um homem possui o direito de desobedecer a lei, se esse direito possui um sentido forte, e, sempre que a lei erroneamente invade direitos que ele tem contra o Estado. Essa é uma característica desses direitos e, para Dworkin, negar tal característica é negar a própria existência desses direitos. ${ }^{409}$

Dworkin também nos demonstra a quase incoerência da cláusula do "dever geral" de que todos devam obedecer a lei. No mínimo, com isso, Dworkin pretende apontar que não devemos nos conformar nem nos reduzir ortodoxamente à lei, uma vez que ela deve ser compreendida enquanto uma densificação principiológica, não direcionada a prejudicar os cidadãos. Imaginemos, portanto, em um simples exemplo, que um homem possua, em decorrência da liberdade de expressão, um direito à manifestação. Nesse sentido, ele deve acreditar que o Estado erraria ao impedir o exercício desse direito, com ou sem o respaldo legal. E "se ele está autorizado a acreditar nisso, é tolice falar de um dever de obedecer à lei enquanto tal, ou de um dever de aceitar uma punição que o Estado não tem o direito de aplicar". 410

\footnotetext{
${ }^{403}$ DWORKIN, Ronald. Levando os direitos a sério. Tradução: Nelson Boeira, 3.ed. São Paulo: Editora WMF Martins Fontes, 2010, p. 233.

${ }^{404}$ No contexto estadunidense.

${ }^{405}$ DWORKIN, Ronald. Levando os direitos a sério. Tradução: Nelson Boeira, 3.ed. São Paulo: Editora WMF Martins Fontes, 2010, p. 292.

${ }^{406}$ Governo, no sentido americano Government, que abrange os três Poderes: Judiciário, Legislativo e Executivo. ${ }^{407}$ DWORKIN, Ronald. Levando os direitos a sério. Tradução: Nelson Boeira, 3.ed. São Paulo: Editora WMF Martins Fontes, 2010, p. 228.

${ }^{408}$ DWORKIN, Ronald. Levando os direitos a sério. Tradução: Nelson Boeira, 3.ed. São Paulo: Editora WMF Martins Fontes, 2010, p. 294.

${ }^{409}$ DWORKIN, Ronald. Levando os direitos a sério. Tradução: Nelson Boeira, 3.ed. São Paulo: Editora WMF Martins Fontes, 2010, p. 295.

${ }^{410}$ DWORKIN, Ronald. Levando os direitos a sério. Tradução: Nelson Boeira, 3.ed. São Paulo: Editora WMF Martins Fontes, 2010, p. 296.
} 
Diante disso, os "conservadores" argumentarão que a lei proíbe a manifestação no caso de existir algum princípio mais importante do que o direito individual à liberdade de expressão, a saber, o princípio do respeito à lei. Contudo, para Dworkin, esse argumento somente encontra plausibilidade se nos esquecemos do que significa dizer que um indivíduo possui um direito contra o Estado. ${ }^{411}$

Ainda acerca dessa perspectiva, para Dworkin, "a perspectiva de ganhos utilitaristas não pode justificar que se impeça um homem de fazer o que tem direito de fazer. Os supostos ganhos resultantes do respeito à lei são meros ganhos utilitaristas". ${ }^{412}$ Aqui, não se está dizendo que o Estado não possa ter justificativas para limitar direitos de seus concidadãos com base em outros fundamentos. Pelo contrário, Dworkin admite essa limitação. Contudo, devemos observar quais direitos o Estado está a limitar e quais são os fundamentos utilizados para tanto. ${ }^{413}$ Dworkin aponta para o caso dos direitos concorrentes que seriam ameaçados caso o direito em questão não fosse limitado. Ele menciona o caso da lei sobre difamação, que restringe o direito pessoal de se dizer o que pensa, porque exige que as afirmações humanas sejam bem fundamentadas. Essa lei encontra justificação plausível, ainda que se acredite que ela viole um direito pessoal, pelo fato de proteger o direito de outros a não terem a reputação arruinada por uma afirmação descuidada. Assim, é perfeitamente possível, e necessário, uma vez que a tensão é produtiva, que os direitos individuais entrem frequentemente em conflito. Mas quando isso acontece, ressalta Dworkin, cabe ao intérprete escolher, de forma acertada, o direito mais importante, e conferir-lhe proteção. Se agir dessa forma, ele não terá enfraquecido a noção de direito. Por isso, devemos reconhecer que o Estado tem razão para restringir direitos, se, com plausibilidade, acreditar que um dos direitos concorrentes é o mais importante. $^{414}$

\subsubsection{Uma crítica aos argumentos utilitaristas e aos seus benefícios especulativos. $O$ perigo das maiorias?}

A noção da existência de direitos contra o Estado põe-se em risco se este colocar em segundo plano um direito individual forte, ao apelar para o direito de uma maioria

\footnotetext{
${ }^{411}$ DWORKIN, Ronald. Levando os direitos a sério. Tradução: Nelson Boeira, 3.ed. São Paulo: Editora WMF Martins Fontes, 2010, p. 296.

${ }^{412}$ DWORKIN, Ronald. Levando os direitos a sério. Tradução: Nelson Boeira, 3.ed. São Paulo: Editora WMF Martins Fontes, 2010, p. 296.

${ }^{413}$ DWORKIN, Ronald. Levando os direitos a sério. Tradução: Nelson Boeira, 3.ed. São Paulo: Editora WMF Martins Fontes, 2010, p. 297.

${ }^{414}$ DWORKIN, Ronald. Levando os direitos a sério. Tradução: Nelson Boeira, 3.ed. São Paulo: Editora WMF Martins Fontes, 2010, p. 297.
} 
democrática de fazer valer sua vontade. Ressalte-se, mais uma vez, que, "um direito contra o Estado deve ser um direito de fazer algo mesmo quando a maioria considera errado fazer tal coisa, ainda que a maioria fique prejudicada em razão disso". Tal afirmação pode soar muito radical se não compreendermos a noção de que um homem possui direitos fortes contra o Estado. ${ }^{415}$

Lembremo-nos que a preservação de uma gama de direitos que agasalham a maioria social depende, em verdade, de reconhecermos enquanto direitos concorrentes apenas aqueles pertencentes a outros membros da sociedade, tomados como indivíduos. ${ }^{416}$ Assim, "direitos" da maioria enquanto tal, que não podem valer como justificação para invalidar os direitos individuais, não se confundem com os direitos pessoais de uma maioria, que podem ser levados em conta. ${ }^{417}$

Nessa esteira, apontamos a diferenciação-chave na teoria dworkineana entre argumentos de princípio, que são destinados a estabelecer um direito individual, e argumentos de política, que são destinados a estabelecer um objetivo coletivo. ${ }^{418}$ Aqui, temos que os argumentos de princípio descrevem direitos, enquanto os argumentos de política descrevem objetivos. Portanto, torna-se importante diferenciar direitos de objetivos. Veremos com mais profundidade esses tipos de argumento ainda neste estudo.

Pois bem, sabemos que, para Dworkin, “(...) o benefício geral não pode ser uma boa razão para a restrição dos direitos". ${ }^{419}$ Mas por que devemos criticar o fato de uma maioria democrática fazer valer sua vontade? ${ }^{420}$

Para Dworkin, o utilitarismo faz parte do grupo proeminente das teorias que se ancoram na argumentação orientada sobre qual deve ser o objetivo da ação política, em prol de um bem-estar da comunidade. O utilitarismo, portanto, "supõe que a comunidade está em melhor situação se seus membros forem, na média, mais felizes ou se tiverem mais preferências satisfeitas". ${ }^{421}$

\footnotetext{
${ }^{415}$ DWORKIN, Ronald. Levando os direitos a sério. Tradução: Nelson Boeira, 3.ed. São Paulo: Editora WMF Martins Fontes, 2010, p. 297.

${ }^{416}$ DWORKIN, Ronald. Levando os direitos a sério. Tradução: Nelson Boeira, 3.ed. São Paulo: Editora WMF Martins Fontes, 2010, p. 298.

${ }^{417}$ DWORKIN, Ronald. Levando os direitos a sério. Tradução: Nelson Boeira, 3.ed. São Paulo: Editora WMF Martins Fontes, 2010, p. 298.

${ }^{418}$ DWORKIN, Ronald. Levando os direitos a sério. Tradução: Nelson Boeira, 3.ed. São Paulo: Editora WMF Martins Fontes, 2010, p. 141.

${ }^{419}$ DWORKIN, Ronald. Levando os direitos a sério. Tradução: Nelson Boeira, 3.ed. São Paulo: Editora WMF Martins Fontes, 2010, p. 296.

${ }^{420}$ DWORKIN, Ronald. Levando os direitos a sério. Tradução: Nelson Boeira, 3.ed. São Paulo: Editora WMF Martins Fontes, 2010, p. 298.

${ }^{421}$ DWORKIN, Ronald. Uma questão de princípio. Título original: A Matter of Principle. Tradução de Luís Carlos Borges. 2. ed. São Paulo: Martins Fontes, 2005, p. 534.
} 
$\mathrm{Na}$ política das democracias ocidentais, o direito tende a conferir prevalência a justificativas utilitaristas enquanto justificativas de fundo sobre decisões políticas. Os argumentos utilitaristas figuram, hoje, as justificativas mais influentes. Destarte, "o utilitarismo deve seu apelo, qualquer que seja ele, ao que poderíamos chamar de seu matiz igualitário", 422 que, por sua vez, “(...) afirma que as pessoas são tratadas como iguais quando as preferências de cada uma, avaliadas apenas no que diz respeito à intensidade, são equilibradas na mesma balança, sem nenhuma distinção de pessoa ou mérito". 423

Levemos em conta um caso concreto: quando discorre sobre a liberdade de expressão versus a lei contra distúrbios públicos, de Chicago, Dworkin defende que proibir um homem de falar ou de manifestar-se equivale a insultá-lo de forma incontestável e profunda, em troca de um benefício geral especulativo. E um Estado que quer levar os direitos a sério não deve trabalhar com experimentos, tentativas, extremas incertezas, especulações. ${ }^{424}$ Pode-se dizer que a lei contra distúrbios públicos permite a expressão das ideias de um homem de modo não provocativo. Contudo, isso "ignora o problema da conexão entre expressão e dignidade" e “(...) é arrogância da maioria pressupor que os métodos ortodoxos de expressão sejam as maneiras adequadas de falar, pois isso é uma negação ao direito da igual consideração e respeito". ${ }^{425}$ Devemos direcionar nossos juízos sobre a linguagem apropriada levando em conta a personalidade dos dissidentes que estão se expressando, "e não a personalidade de uma maioria silenciosa, que em nada é restringida pela lei contra os distúrbios públicos". ${ }^{426}$

No caso em tela, Dworkin busca examinar a existência de direitos concorrentes que sejam plausivelmente capazes de justificar a restrição trazida pela lei contra os distúrbios públicos. Os únicos direitos concorrentes plausíveis seriam os direitos de estar livre da violência, de modo que "a violência é a única ameaça plausível à sociedade que este contexto nos fornece". ${ }^{427}$ A partir de então, Dworkin constata que os réus do processo de Chicago não foram acusados de violência direta, sendo que o argumento corrente baseou-se na possibilidade de que os atos de fala que eles planejaram pudessem fazer com que outros

\footnotetext{
${ }^{422}$ DWORKIN, Ronald. Uma questão de princípio. Título original: A Matter of Principle. Tradução de Luís Carlos Borges. 2. ed. São Paulo: Martins Fontes, 2005, p. 537.

${ }^{423}$ DWORKIN, Ronald. Uma questão de princípio. Título original: A Matter of Principle. Tradução de Luís Carlos Borges. 2. ed. São Paulo: Martins Fontes, 2005, p. 537.

${ }^{424}$ DWORKIN, Ronald. Levando os direitos a sério. Tradução: Nelson Boeira, 3.ed. São Paulo: Editora WMF Martins Fontes, 2010, p. 308; 310.

${ }^{425}$ DWORKIN, Ronald. Levando os direitos a sério. Tradução: Nelson Boeira, 3.ed. São Paulo: Editora WMF Martins Fontes, 2010, p. 309.

${ }^{426}$ DWORKIN, Ronald. Levando os direitos a sério. Tradução: Nelson Boeira, 3.ed. São Paulo: Editora WMF Martins Fontes, 2010, p. 309.

${ }^{427}$ DWORKIN, Ronald. Levando os direitos a sério. Tradução: Nelson Boeira, 3.ed. São Paulo: Editora WMF Martins Fontes, 2010, p. 309.
} 
cometessem atos de violência, seja em apoio, seja como reação hostil ao que disseram. Mas isso, para Dworkin, não conta como justificativa ${ }^{428}$, porque se os direitos significam alguma coisa, o Estado não pode simplesmente pressupor respostas justificadoras de sua conduta. Dworkin ressalta que “(...) o perigo existente em permitir que ele fale é especulativo”. 429 Assim, os direitos dos cidadãos não devem ser anulados por supostas razões de bem-estar geral. $^{430}$

Por outro lado, o argumento utilitarista é atraente, por aparentar um igualitarismo, uma vez que trata os desejos dos membros da comunidade como equivalentes. Não obstante, Dworkin assevera que "o caráter igualitário de um argumento utilitarista é frequentemente uma ilusão". ${ }^{431}$ Isso porque "é impossível conceber procedimentos políticos que discriminem com precisão entre preferências pessoais e externas". ${ }^{432}$

Nesse sentido, Dworkin realiza uma crítica à democracia representativa: ela funciona imperfeitamente, pois a regra de decisão pela maioria não consegue levar suficientemente em conta a intensidade das preferências particulares.

(...) a democracia não é capaz de discriminar entre os diferentes componentes pessoais - convicções que o indivíduo escolhe para si mesmos - e externos preferências para impor uma forma de vida apropriada às outras pessoas - de modo que ofereça um método para implementar os primeiros e ignorar os últimos. ${ }^{433}{ }^{434}$

Frente a essa incapacidade de discriminação entre componentes pessoais e preferências externas, Dworkin elucida: "não quero dizer que endossar o direito de alguém ter suas preferências satisfeitas automaticamente endossa suas preferências como boas ou nobres". ${ }^{435}$ O utilitarismo, é possível dizer, ampara-se em motivos de preferências morais

\footnotetext{
${ }^{428}$ DWORKIN, Ronald. Levando os direitos a sério. Tradução: Nelson Boeira, 3.ed. São Paulo: Editora WMF Martins Fontes, 2010, p. 310.

${ }^{429}$ DWORKIN, Ronald. Levando os direitos a sério. Tradução: Nelson Boeira, 3.ed. São Paulo: Editora WMF Martins Fontes, 2010, p. 311.

${ }^{430}$ DWORKIN, Ronald. Levando os direitos a sério. Tradução: Nelson Boeira, 3.ed. São Paulo: Editora WMF Martins Fontes, 2010, p. 313.

${ }^{431}$ DWORKIN, Ronald. Levando os direitos a sério. Tradução: Nelson Boeira, 3.ed. São Paulo: Editora WMF Martins Fontes, 2010, p. 423.

${ }^{432}$ DWORKIN, Ronald. Levando os direitos a sério. Tradução: Nelson Boeira, 3.ed. São Paulo: Editora WMF Martins Fontes, 2010, p. 425.

${ }^{433}$ DWORKIN, Ronald. Levando os direitos a sério. Tradução: Nelson Boeira, 3.ed. São Paulo: Editora WMF Martins Fontes, 2010, p. 425.

${ }^{434}$ Para mais críticas à democracia, ver: DWORKIN, Ronald. A raposa e o porco-espinho: justiça e valor. Tradução de Marcelo Brandão Cipolla. São Paulo: Editora WMF Martins Fontes, 2014, p. 356.

${ }^{435}$ DWORKIN, Ronald. Uma questão de princípio. Título original: A Matter of Principle. Tradução de Luís Carlos Borges. 2. ed. São Paulo: Martins Fontes, 2005, p. 540.
} 
sobre como os outros devem comportar-se. ${ }^{436}$

Sem o intento de desprezar as qualidades e os benefícios da democracia representativa, é importante, contudo, alertar para o risco de imposições advindas pelas maiorias. Qual seria o perigo das maiorias? É também neste ponto que a crítica tecida por Dworkin aos argumentos utilitaristas coaduna-se com o discurso comunicativo habermasiano.

Em "A inclusão do outro", Habermas aponta o lado obscuro do pressuposto da homogeneidade nacional, demandada por Carl Schmitt, que implicaria em unidade política, na retomada da ideia grega de democracia enquanto identidade entre governante e governado. A ideia de democracia, para Schmitt, pode ser facilmente resgatada na forma de uma ditadura. Ao considerar o pressuposto da homogeneidade do povo, Schmitt desconsidera a intersubjetividade dos cidadãos - direitos fundamentais e uso das liberdades subjetivas. Quando uma democracia é introduzida com a ideia de auto-afirmação coletiva, o cidadão não consegue exercer uma série de direitos fundamentais fora do contexto de um povo constituído em nação. ${ }^{437}$ Com isso, abre-se espaço para o uso de políticas repressivas, como a assimilação coercitiva de elementos estranhos e ideias como a preservação da pureza de um povo (apartheid, limpezas étnicas). A homogeneidade destaca o inimigo, que é caçado e eliminado. Schmitt chega a falar na "submissão e evacuação da população heterogênea", assim como em sua segregação geográfica. ${ }^{438}$

A partir da compreensão de uma razão intersubjetiva, Habermas defende a abertura para a comunicação, para o olhar crítico, defendendo que o ponto característico da época moderna "é a transferência do poder legítimo para um nível reflexivo da justificação". ${ }^{439}$ Para Habermas, devemos lutar por uma ordem política aberta que inclua marginalizados sem confiná-los na ideia de comunidade homogênea de um povo.

Vale apontar, dessa forma, para o risco de uma cultura majoritária dominante, que impinge invisivelmente regras repressivas, ainda que inserta em uma comunidade republicana que garanta formalmente a igualdade de direitos para todos. E, com isso, a possibilidade de eclosão de "um conflito cultural movido pelas minorias desprezadas contra a cultura da maioria". 440

O problema também surge em sociedades democráticas, quando uma cultura majoritária, no exercício do poder político, impinge às minorias a sua forma de vida, negando assim aos cidadãos de origem cultural diversa uma efetiva igualdade de

\footnotetext{
${ }^{436}$ DWORKIN, Ronald. Uma questão de princípio. Título original: A Matter of Principle. Tradução de Luís Carlos Borges. 2. ed. São Paulo: Martins Fontes, 2005, p. 540.

${ }^{437}$ HABERMAS, Jürgen. A Inclusão do Outro: estudos de teoria política. São Paulo: Loyola, 2002, p. 153-155.

${ }^{438}$ HABERMAS, Jürgen. A Inclusão do Outro: estudos de teoria política. São Paulo: Loyola, 2002, p. 153-155.

${ }^{439}$ HABERMAS, Jürgen. A Inclusão do Outro: estudos de teoria política. São Paulo: Loyola, 2002, p. 158-159.

${ }^{440}$ HABERMAS, Jürgen. A Inclusão do Outro: estudos de teoria política. São Paulo: Loyola, 2002, p. 165.
} 
direitos. Isso tange questões políticas, que tocam o auto-entendimento ético e a identidade dos cidadãos. Nessas matérias, as minorias não devem ser submetidas sem mais nem menos às regras da maioria. O princípio majoritário chega aqui a seu limite $(\ldots)^{441}$

Dessa forma, verificamos que a crítica dworkineana à democracia representativa e aos seus argumentos utilitaristas se preocupa com a questão de uma cultura majoritária impositora de regras. Percebemos, aqui, a validade da preocupação de Dworkin, segundo a qual o utilitarismo irrestrito leva a resultados evidentemente inegualitários. ${ }^{442}$

Lembremo-nos, então, que essa abertura comunicativa proposta por Habermas faz-se crucial nos contextos democráticos, direcionados à permissão não apenas do consenso, mas também, e, principalmente, do dissenso. Vale apontar, a título de exemplo, a importância conferida a essa abertura em decisão pelo Supremo Tribunal Federal brasileiro, mais especificamente, na Ação Direta de Inconstitucionalidade n. 4.815/DF ${ }^{443}$, onde a Ministra Carmen Lúcia considerou os argumentos apresentados em audiência pública pela Associação Brasileira dos Constitucionalistas Democratas (Roberto Dias):

(...) a democracia, mais do que regime do consenso, é regime do dissenso; no Habeas Data $\mathrm{n}^{\circ} 22$, relatado pelo Ministro Celso de Mello, afirma-se, com base no pensamento de Noberto Bobbio, que o nosso modelo político jurídico atual, não autoriza poder que oculta e que se oculta. ${ }^{444}$

Para Dworkin, os utilitaristas reduzem a justiça a uma questão de agregação (tese agregativa), de aumentar o bem-estar geral da comunidade como um todo. ${ }^{445}$ Assim, como resposta aos defeitos filosóficos do utilitarismo, percebemos, em Dworkin, uma teoria geral dos direitos baseada no conceito de direito político individual, no sentido antiutilitarista forte ${ }^{446}{ }^{447}$, a qual direcionaremos nossos esforços para lograr sua compreensão.

\footnotetext{
${ }^{441}$ HABERMAS, Jürgen. A Inclusão do Outro: estudos de teoria política. São Paulo: Loyola, 2002, p. 164.

${ }^{442}$ DWORKIN, Ronald. Uma questão de princípio. Título original: A Matter of Principle. Tradução de Luís Carlos Borges. 2. ed. São Paulo: Martins Fontes, 2005, p. 540.

${ }^{443} \mathrm{Na}$ referida decisão, por unanimidade, o Plenário do Supremo Tribunal Federal julgou procedente a Ação Direta de Inconstitucionalidade (ADI) 4815-DF e declarou inexigível a autorização prévia para a publicação de biografias. Seguindo o voto da relatora, ministra Cármen Lúcia, "a decisão dá interpretação conforme a Constituição da República aos artigos 20 e 21 do Código Civil, em consonância com os direitos fundamentais à liberdade de expressão da atividade intelectual, artística, científica e de comunicação, independentemente de censura ou licença de pessoa biografada, relativamente a obras biográficas literárias ou audiovisuais (ou de seus familiares, em caso de pessoas falecidas)".

${ }^{444}$ Ação Direta de Inconstitucionalidade n. 4.815 - Distrito Federal. Relatora: Min. Carmen Lúcia. Disponível em: < http://www.stf.jus.br/arquivo/cms/noticiaNoticiaStf/anexo/ADI4815relatora.pdf>. Acesso em 26 mai.2015.

${ }^{445}$ DWORKIN, Ronald. A raposa e o porco-espinho: justiça e valor. Tradução de Marcelo Brandão Cipolla. São Paulo: Editora WMF Martins Fontes, 2014, p. 337.

${ }^{446}$ DWORKIN, Ronald. Levando os direitos a sério. Tradução: Nelson Boeira, 3.ed. São Paulo: Editora WMF Martins Fontes, 2010, p. 426.
} 


\subsubsection{O que é um direito em sentido forte? A ideia de direitos fundamentais como trunfos}

O intento de descrever o ajuste político que Dworkin entende ser exigido pela justiça é aprofundado em "Justice for Hedgehogs" "448. O capítulo 15 dessa obra trata de direitos e conceitos políticos.

Sabemos que existem direitos individuais tão importantes que devem ser protegidos até mesmo contra as políticas que efetivamente melhorariam uma coletividade. Esses direitos são tratados como direitos fortes. Mas que direitos temos contra nosso Estado? É nesse momento que Dworkin desenvolve a ideia de direitos políticos como trunfos sobre quaisquer outras justificações. $^{449}$

Uma comunidade política só tem autoridade moral para exercer coerção sobre alguém, criando-lhe e impondo-lhe obrigações se respeitar dois requisitos: igual consideração e respeito; e respeito às responsabilidades individuais. Em seus programas de ação política, o Estado deve considerar, portanto, "todos os seus destinos como igualmente importantes" além de respeitar a responsabilidade individual de cada um deles pela própria vida. ${ }^{450} \mathrm{Nas}$ palavras de Dworkin:

I suggest two reigning principles. First, government must show equal concern for the fate of every person, every citizen over whom it claims dominion. Second, government must respect the responsibility and right of each person to make something of value out of his or her life. So: equal concern and equal respect for responsibility. ${ }^{451}$

A partir da compreensão do reinado desses princípios é possível aclarar a importância do argumento de como as pessoas em coletividade, mediante o Estado, devem ser tratadas enquanto indivíduos. Ou seja: "how people collectively, through government, should treat

\footnotetext{
${ }^{447}$ Para mais críticas ao utilitarismo - exemplo da preocupação igual dos pais para com os filhos - ver: DWORKIN, Ronald. A raposa e o porco-espinho: justiça e valor. Tradução de Marcelo Brandão Cipolla. São Paulo: Editora WMF Martins Fontes, 2014, p. 362.

${ }^{448}$ DWORKIN, Ronald. A raposa e o porco-espinho: justiça e valor. Tradução de Marcelo Brandão Cipolla. São Paulo: Editora WMF Martins Fontes, 2014, p. 499.

${ }^{449}$ DWORKIN, Ronald. A raposa e o porco-espinho: justiça e valor. Tradução de Marcelo Brandão Cipolla. São Paulo: Editora WMF Martins Fontes, 2014, p. 501 e ss.

${ }^{450}$ DWORKIN, Ronald. A raposa e o porco-espinho: justiça e valor. Tradução de Marcelo Brandão Cipolla. São Paulo: Editora WMF Martins Fontes, 2014, p. 503.

${ }^{451}$ DWORKIN, Ronald. Justice for Hedgehogs. Keynote address. In: Boston University. Disponível em: < http://www.bu.edu/law/journals-archive/bulr/documents/dworkin_k.pdf>. Acesso em 15 fev. 2015.
} 
themselves as individuals". ${ }^{452}$ Assim, cada ato do Estado deve ser justificado no respeito a esses dois princípios fundamentais. Trata-se de princípios legitimadores, que formam a fonte mais abstrata dos direitos políticos. ${ }^{453}$

Para Dworkin, só há sentido em se dizer que um homem tem um direito fundamental contra o Estado, no sentido forte, se esse direito for necessário para proteger as ideias da dignidade humana - vaga, mas poderosa - e sua posição enquanto detentor da mesma consideração e do mesmo respeito - igualdade política. ${ }^{454}$

Nesse sentido, a violação de um direito em sentido forte é uma questão muito séria. Significa "tratar um homem como menos que um homem ou como se fosse menos digno de consideração que outros homens". ${ }^{455}$

Nesse sentido, Dworkin acrescenta que os princípios de dignidade declaram direitos políticos muito abstratos, que ganham, como trunfos, das políticas coletivas do governo; e que "todos os direitos políticos derivam desse direito fundamental". 456

A partir de então, queda-nos o seguinte questionamento: Serão os direitos humanos realmente universais? Ou será que qualquer lista é apenas local? Os direitos humanos dependem da cultura/história local, que as declarações universais ignoram? Ou será que existem alguns direitos humanos, pelo menos, independentes dessas circunstâncias? Diante de questões como essas, Dworkin afirma que o juízo interpretativo deve ser sensível às diferenças. Porém, a compreensão básica de que a dignidade humana exige preocupação e respeito iguais e o respeito pela responsabilidade pessoal compõe um "padrão abstrato" que não é relativo, mas "genuinamente universal". ${ }^{457}$

Finalmente, "nas democracias maduras, quase todos reconhecem, na qualidade de tese abstrata, que o Estado deve tratar os governados com igual consideração e deve conceder-lhes as liberdades de que precisam para definir uma vida bem-sucedida para si próprios". ${ }^{458}$ No entanto, Dworkin reconhece não haver concordância acerca de quais são os direitos mais

\footnotetext{
${ }^{452}$ DWORKIN, Ronald. Justice for Hedgehogs. Keynote address. In: Boston University. Disponível em: < http://www.bu.edu/law/journals-archive/bulr/documents/dworkin_k.pdf>. Acesso em 15 fev. 2015.

${ }^{453}$ DWORKIN, Ronald. A raposa e o porco-espinho: justiça e valor. Tradução de Marcelo Brandão Cipolla. São Paulo: Editora WMF Martins Fontes, 2014, p. 504.

${ }^{454}$ DWORKIN, Ronald. Levando os direitos a sério. Tradução: Nelson Boeira, 3.ed. São Paulo: Editora WMF Martins Fontes, 2010, p. 305.

${ }^{455}$ DWORKIN, Ronald. Levando os direitos a sério. Tradução: Nelson Boeira, 3.ed. São Paulo: Editora WMF Martins Fontes, 2010, p. 305 e ss.

${ }^{456}$ DWORKIN, Ronald. A raposa e o porco-espinho: justiça e valor. Tradução de Marcelo Brandão Cipolla. São Paulo: Editora WMF Martins Fontes, 2014, p. 504.

${ }^{457}$ DWORKIN, Ronald. A raposa e o porco-espinho: justiça e valor. Tradução de Marcelo Brandão Cipolla. São Paulo: Editora WMF Martins Fontes, 2014, p. 507-517.

${ }^{458}$ DWORKIN, Ronald. A raposa e o porco-espinho: justiça e valor. Tradução de Marcelo Brandão Cipolla. São Paulo: Editora WMF Martins Fontes, 2014, p. 504.
} 
concretos que decorrem desses direitos abstratos. A busca por essa resposta é orientada pelo desenvolvimento de uma teoria substantiva dos direitos políticos como trunfos. Essa teoria, ressalte-se, é construída com base nos conceitos interpretativos principais dos dois princípios fundamentais da dignidade, "de modo que cada um deles complemente o outro e o reforce". Para isso, a teoria de Dworkin rejeita a opinião popular de que a liberdade e a igualdade são valores conflitantes. ${ }^{459}$

Portanto, os dois postulados dworkineanos serão melhor compreendidos ao aprofundarmos essa ideia de liberdade e igualdade enquanto princípios conjuntos, inextricavelmente ligados ${ }^{460}$, o que será abordado a seguir neste estudo.

\footnotetext{
${ }^{459}$ DWORKIN, Ronald. A raposa e o porco-espinho: justiça e valor. Tradução de Marcelo Brandão Cipolla. São Paulo: Editora WMF Martins Fontes, 2014, p. 504-505.

${ }^{460}$ DWORKIN, Ronald. A raposa e o porco-espinho: justiça e valor. Tradução de Marcelo Brandão Cipolla. São Paulo: Editora WMF Martins Fontes, 2014, p. 505.
} 


\section{PARTE III - O DISCURSO DO ÓDIO E OS POSTULADOS DA IGUAL CONSIDERAÇÃO E RESPEITO E DA LIBERDADE DE EXPRESSÃO. UMA ANÁLISE DO CASO ELLWANGER}

\section{LIBERDADE E IGUALDADE: PRINCÍPIOS QUE SE REFORÇAM}

\subsection{QUAL É O PONTO DE ENCONTRO ENTRE OS CONCEITOS DE IGUALDADE E DE LIBERDADE?}

Ao tratar da suposta existência de um direito à liberdade, Dworkin inicia sua exposição apontando que "tornou-se comum descrever as grandes questões sociais de política interna e, em particular, a questão racial como paradigmas de conflitos entre as exigências da liberdade e da igualdade”. Nesse sentido, ele afirma ser possível que os pobres, os negros, os trabalhadores não especializados e os carentes de educação, por exemplo, tenham um direito abstrato à igualdade. Não obstante, os prósperos, os brancos, os instruídos, e os trabalhadores especializados também têm um direito à liberdade. Portanto, os dois conjuntos de direitos merecem consideração e respeito. ${ }^{461}$

À exceção dos extremistas, assevera Dworkin, "todos reconhecem a necessidade de se chegar a um acordo entre a igualdade e a liberdade". No entanto, "qualquer parcela de legislação social importante, desde a política tributária até os projetos de integração, é moldada pela suposta tensão entre esses dois objetivos". 462

Dworkin parte desse suposto conflito entre igualdade e liberdade para perguntar se temos um direito à liberdade. Se temos direito a liberdades, então devemos compreender que os demais também possuem esse direito em igual quota de respeito. Afinal de contas, temos um direito à liberdade?

Dworkin cita o famoso ensaio moderno sobre a liberdade, de Isaiah Berlin ${ }^{463}$, e a respectiva noção de liberdade como licença, como ausência de frustração e de obstáculos às escolhas e atividades possíveis. ${ }^{464}$ Para Bentham, "qualquer lei é uma infração contra a

\footnotetext{
${ }^{461}$ DWORKIN, Ronald. Levando os direitos a sério. Tradução: Nelson Boeira, 3.ed. São Paulo: Editora WMF Martins Fontes, 2010, p. 410.

${ }^{462}$ DWORKIN, Ronald. Levando os direitos a sério. Tradução: Nelson Boeira, 3.ed. São Paulo: Editora WMF Martins Fontes, 2010, p. 410.

${ }^{463}$ Cf. BERLIN, Isaiah. Two Concepts of Liberty (1958). In: Liberty (Oxford University Press, Oxford 2002), p. 169-178.

${ }^{464}$ DWORKIN, Ronald. Levando os direitos a sério. Tradução: Nelson Boeira, 3.ed. São Paulo: Editora WMF Martins Fontes, 2010, p. 411.
} 
liberdade”. E, ainda, de acordo com a definição clássica de John Stuart Mill, a liberdade é a de se fazer o que se quer. ${ }^{465}$

Todavia, se considerarmos essa definição tradicional de liberdade (tradição liberal) percebemos uma nítida competição entre liberdade e igualdade. O sentido neutro e abrangente de liberdade como licença desemboca, com evidência, na competição entre liberdade e igualdade. Ora, leis são necessárias para proteger a igualdade e, inevitavelmente, envolverão limitações à liberdade, explica Dworkin. ${ }^{466}$ Portanto, o sentido neutro da liberdade parece causar mais confusão que esclarecimento. Tal compreensão dilui a noção de direito e enfraquece a de liberdade, uma vez que, sob a perspectiva clássica, uma pessoa tem um direito à liberdade se for de seu interesse ter essa liberdade, e o "querer" liberdade não exige nenhuma concessão quanto aos esforços necessários para conferir a outras mulheres e a outros homens a igualdade que é sua prerrogativa. Verifica-se, a partir de então, que a liberdade precisa configurar um direito muito mais forte para que desempenhe o papel a ela talhado no debate político. ${ }^{467} \mathrm{E}$, se considerado em sentido forte, então é errado privar uma pessoa desse direito. Portanto, percebemos que, evidentemente, "não existe nenhum direito geral à liberdade enquanto tal". 468

Ainda que considerássemos o que adicionou Bentham à sua teoria, a saber, que toda lei é uma violação à liberdade, mas que só temos o direito de nos proteger contra as violações graves ou fundamentais, ou seja, teríamos o direito às liberdades básicas e importantes; essa compreensão não responde o que está em jogo nos casos a caracterizarem liberdades importantes. ${ }^{469}$

Mas como explicar isso? Por que determinadas restrições à liberdade são consideradas injustas, e outras, não? Por que há restrições à liberdade que ocasionam um impacto especial sobre a liberdade enquanto tal? Por que, em uma democracia, os cidadãos têm direitos a algum tipo específico de liberdade, como a liberdade de expressão, a liberdade religiosa? ${ }^{470}$

\footnotetext{
${ }^{465}$ DWORKIN, Ronald. A raposa e o porco-espinho: justiça e valor. Tradução de Marcelo Brandão Cipolla. São Paulo: Editora WMF Martins Fontes, 2014, p. 557 e ss.

${ }^{466}$ DWORKIN, Ronald. Levando os direitos a sério. Tradução: Nelson Boeira, 3.ed. São Paulo: Editora WMF Martins Fontes, 2010, p. 412.

${ }^{467}$ DWORKIN, Ronald. Levando os direitos a sério. Tradução: Nelson Boeira, 3.ed. São Paulo: Editora WMF Martins Fontes, 2010, p. 413.

${ }^{468}$ DWORKIN, Ronald. Levando os direitos a sério. Tradução: Nelson Boeira, 3.ed. São Paulo: Editora WMF Martins Fontes, 2010, p. 413-414.

${ }^{469}$ DWORKIN, Ronald. Levando os direitos a sério. Tradução: Nelson Boeira, 3.ed. São Paulo: Editora WMF Martins Fontes, 2010, p. 415.

${ }^{470}$ DWORKIN, Ronald. Levando os direitos a sério. Tradução: Nelson Boeira, 3.ed. São Paulo: Editora WMF Martins Fontes, 2010, p. 417.
} 
Ao afirmar ser irrelevante o argumento de utilidade geral, devido a sua incapacidade de defender os direitos enquanto tais, Dworkin procura um argumento para além dessa utilidade. $^{471}$

A partir de então, a igualdade posiciona-se enquanto conceito central na argumentação dworkineana. ${ }^{472}$ Temos, aqui, o postulado orientador exigido pela justiça: a igual consideração e respeito. O Estado deve, portanto, tratar as pessoas não somente com consideração e respeito, mas com igual consideração e respeito. Trata-se da "concepção liberal da igualdade" - treatment as an equal. ${ }^{473}$

O argumento defendido por Dworkin é o de que "os direitos individuais a diferentes liberdades devam ser reconhecidos somente quando se puder mostrar que o direito fundamental a ser tratado como igual (treatment as an equal) exige tais direitos". 474

Dessa forma, se uma determinada liberdade for exigida pelo princípio da igual consideração e respeito, então ela merece reconhecimento enquanto um direito forte, um verdadeiro trunfo contra o Estado.

$\mathrm{Na}$ proposta dworkineana, o direito a diferentes liberdades não entra em conflito com o direito à igualdade, uma vez que não são direitos concorrentes, ao contrário, o direito a uma determinada liberdade é exigência da própria igualdade, decorre da concepção fundamental de igualdade. $^{475}$

É neste ponto que encontramos a evidência de que liberdade e igualdade se pressupõem. Portanto, a compreensão obtida a partir da teoria dworkineana permite-nos ressignificar a noção tradicional e ultrapassada que implica na tensão entre esses dois conceitos. Torna-se possível, e mais que isso, crucial, que reconciliemos essas noções.

\subsection{O PANORAMA DAS LIBERDADES: LIBERTY E FREEDOM}

A teoria da liberdade sugerida por Dworkin é agraciada por uma universalidade indiscutível. Que liberdades temos, de fato? Qual o alcance pode tomar o édito estatal em minha vida?

\footnotetext{
${ }^{471}$ DWORKIN, Ronald. Levando os direitos a sério. Tradução: Nelson Boeira, 3.ed. São Paulo: Editora WMF Martins Fontes, 2010, p. 417-418.

${ }^{472}$ DWORKIN, Ronald. Levando os direitos a sério. Tradução: Nelson Boeira, 3.ed. São Paulo: Editora WMF Martins Fontes, 2010, p. 419.

${ }^{473}$ DWORKIN, Ronald. Levando os direitos a sério. Tradução: Nelson Boeira, 3.ed. São Paulo: Editora WMF Martins Fontes, 2010, p. 420.

${ }^{474}$ DWORKIN, Ronald. Levando os direitos a sério. Tradução: Nelson Boeira, 3.ed. São Paulo: Editora WMF Martins Fontes, 2010, p. 421.

${ }^{475}$ DWORKIN, Ronald. Levando os direitos a sério. Tradução: Nelson Boeira, 3.ed. São Paulo: Editora WMF Martins Fontes, 2010, p. 421.
} 
Em Justice for Hedgehogs, Dworkin aprofunda-se no conceito de liberdade, enquanto um conceito interpretativo, assim como o de igualdade. Dworkin rejeita, uma vez mais, o conflito entre liberdade e igualdade:

We need a theory of liberty as well, and we must be aware of the danger that any plausible theory of liberty will conflict with the egalitarian theory of distributive justice I just described. It was Isaiah Berlin's claim that this is necessarily the case. $^{476}$

Há dois conceitos interpretativos de liberdade: a liberdade positiva estipula o que significa as pessoas participarem de forma correta; e liberdade negativa, que descreve quais escolhas deverão estar isentas das decisões coletivas para que a responsabilidade pessoal seja preservada. Dworkin analisa justamente a teoria da liberdade negativa. ${ }^{477}$

Dworkin realiza uma estipulação terminológica para aclarar o conceito de liberdade ${ }^{478}$ :

I distinguish freedom, which is simply your ability to do anything you might want to do without government restraint, from liberty, which is that part of freedom that government would do wrong to restrain. So I do not accept any general right to freedom. I accept, instead, a right to liberty, and the right that I urge is rather complex. $^{479}$

Nesse caso, "freedom" configura a autonomia total de uma pessoa, a sua capacidade de agir como quiser, livre de condicionalismos ou ameaças impostas por outros ou por uma comunidade política. Já a liberdade negativa, ou apenas liberdade (liberty), é a porção da sua autonomia que uma comunidade não lhe pode retirar sem a ofender de algum modo especial, comprometendo a sua dignidade, ao negar-lhe a preocupação igual ou uma característica essencial da responsabilidade pela sua própria vida. ${ }^{480}$

A partir dessa diferenciação, Dworkin aponta o problema de Isaiah Berlin: ele equiparava a liberdade negativa à autonomia total, enxergando essas duas liberdades como coextensivas, onde qualquer limite à primeira implicaria a uma invasão à segunda. ${ }^{481}$ É também o problema em Mill e em H. L. A. Hart ${ }^{482}$. O Estado não compromete a liberdade dos

\footnotetext{
${ }^{476}$ DWORKIN, Ronald. Justice for Hedgehogs. Keynote address. In: Boston University. Disponível em: < http://www.bu.edu/law/journals-archive/bulr/documents/dworkin_k.pdf>. Acesso em 15 fev. 2015.

${ }^{477}$ DWORKIN, Ronald. A raposa e o porco-espinho: justiça e valor. Tradução de Marcelo Brandão Cipolla. São Paulo: Editora WMF Martins Fontes, 2014, p. 559.

${ }^{478}$ DWORKIN, Ronald. Justiça para Ouriços, p. 375.

${ }^{479}$ DWORKIN, Ronald. Justice for Hedgehogs. Keynote address. In: Boston University. Disponível em: < http://www.bu.edu/law/journals-archive/bulr/documents/dworkin_k.pdf>. Acesso em 15 fev. 2015.

${ }^{480}$ DWORKIN, Ronald. A raposa e o porco-espinho: justiça e valor. Tradução de Marcelo Brandão Cipolla. São Paulo: Editora WMF Martins Fontes, 2014, p. 561.

${ }^{481}$ DWORKIN, Ronald. A raposa e o porco-espinho: justiça e valor. Tradução de Marcelo Brandão Cipolla. São Paulo: Editora WMF Martins Fontes, 2014, p. 561.

${ }^{482}$ Cf. HART, H. L. A. Are there any natural rights? Philosophical Review 64 (1955).
} 
cidadãos nem os insulta quando os proíbe de matar uns aos outros, por exemplo. Pelo contrário, nossa dignidade enquanto cidadãos exige que o Estado nos proteja dessa maneira. Portanto, a liberdade não seria uma autonomia total, mas autonomia substancial. Mas como medir uma quantidade de autonomia perdida mediante uma lei em particular? ${ }^{483}$

Dworkin ressalta que a liberdade não é um conceito criterial, mas interpretativo, e que pode ser melhor compreendida quando associada a um valor mais profundo: o da responsabilidade pessoal.

\subsection{ETHICAL INDEPENDENCE PARA UMA MELHOR COMPREENSÃO DA LIBERDADE}

Dworkin associa a ideia de liberdade ao valor mais profundo da responsabilidade pessoal. $^{484}$

Existem dois tipos de constrangimento: não seria ofensivo, por exemplo, a imposição de regras de trânsito - desde que não sejam disparatadas, ou que uma lei proíba as pessoas de matarem umas às outras, como já foi mencionado, ou que tenham direitos sobre suas propriedades. Não obstante, seria ofensivo para uma pessoa ter que aceitar que uma maioria impusesse uma determinada convicção religiosa, ou que opiniões devem ou não ser expressas em debates políticos. ${ }^{485}$

Um Estado justo deve reconhecer que cada cidadão possui o direito ao que Dworkin denomina independência ética (ethical independence). Nesse sentido, a independência ética engloba as nossas escolhas no âmbito de questões essenciais, que envolvam valores éticos. Nas palavras de Dworkin: "We have a right to make fundamental choices about the meaning and importance of human life for ourselves, the right the Supreme Court ${ }^{486}$ recognized as justifying its holding that government must not prohibit early term abortion."487

Quando o Estado nos pressiona a pagar impostos, a dirigir de forma cautelosa, quando nos proíbe de praticar atos de violência, por exemplo, ele utiliza-se de um argumento ou uma justificação moral, e não ética, e, portanto, não ofende nossa independência ética, tendo em

${ }^{483}$ DWORKIN, Ronald. A raposa e o porco-espinho: justiça e valor. Tradução de Marcelo Brandão Cipolla. São Paulo: Editora WMF Martins Fontes, 2014, p. 562-563.

${ }^{484}$ DWORKIN, Ronald. A raposa e o porco-espinho: justiça e valor. Tradução de Marcelo Brandão Cipolla. São Paulo: Editora WMF Martins Fontes, 2014, p. 561.

${ }^{485}$ DWORKIN, Ronald. A raposa e o porco-espinho: justiça e valor. Tradução de Marcelo Brandão Cipolla. São Paulo: Editora WMF Martins Fontes, 2014, p. 562 e ss.

${ }^{486}$ Planned Parenthood of Se. Pa. v. Casey, 505 U.S. 833, 851 (1992) ("At the heart of liberty is the right to define one's own concept of existence, of meaning, of the universe, and of the mystery of human life."); Roe v. Wade, 410 U.S. 113, 164-65 (1973).

${ }^{487}$ DWORKIN, Ronald. Justice for Hedgehogs. Keynote address. In: Boston University, p. 471-472. Disponível em: < http://www.bu.edu/law/journals-archive/bulr/documents/dworkin_k.pdf>. Acesso em 15 fev. 2015. 
vista que ele não nega nossa responsabilidade de definir valores éticos para nós mesmos, não usurpando nossa responsabilidade de identificar uma vida de sucesso. Assim, "a independência ética não é comprometida quando um assunto não é fundamental e as restrições governamentais não supõem nenhuma justificativa ética”. 488

Por outro lado, existem leis coercitivas que violam a independência ética por negarem às pessoas o poder de tomar suas próprias decisões acerca de questões éticas fundamentais. Dworkin inclui ao rol das questões fundamentais as escolhas referentes à religião, os compromissos pessoais íntimos, os ideais éticos, morais e políticos. Nessa esteira, Dworkin menciona o entendimento de vários juízes da Suprema Corte dos Estados Unidos que se recusaram a permitir que alguns estados americanos proibissem categoricamente o aborto no início da gravidez, apontando que "essas questões envolvem as escolhas mais íntimas e pessoais que a pessoa talvez tenha de fazer em toda a sua vida, escolhas essenciais para a dignidade e a autonomia". Assim, as pessoas possuem um direito a essa independência, desde que não coloquem em risco a igual independência de outras pessoas. ${ }^{489}$

Exemplificamos, acima, leis que violam a independência ética em razão do caráter fundamental das decisões que inibem. Mas também há leis violadoras desse postulado por causa das motivações que o Estado utiliza ao promulgá-las. Trata-se do erro que este comete quando restringe a autonomia do indivíduo apoiando-se numa justificativa que pressuponha a superioridade ou a popularidade de quaisquer valores éticos controversos na comunidade. São leis que, por exemplo, censuram a literatura sexual e as que impõem a obrigatoriedade da saudação à bandeira. Ora, elas refletem uma imposição a uma escolha sobre as virtudes pessoais formadoras de uma boa vida. Ademais, há leis que violam a independência ética das duas maneiras. É o caso da proibição do casamento entre pessoas do mesmo sexo e a censura política, por exemplo. ${ }^{490}$

Assim, as leis com motivos adequados fazem parte do pano de fundo no qual faço as minhas escolhas éticas. A minha responsabilidade ética de fazer essas escolhas não é diminuída por esse pano de fundo. ${ }^{491}$

Dworkin incita uma discussão em torno do alcance aceitável das decisões coletivas nas vidas das pessoas. Qual o seu limite? Dworkin afirma que não obstante a impossibilidade de

\footnotetext{
${ }^{488}$ DWORKIN, Ronald. A raposa e o porco-espinho: justiça e valor. Tradução de Marcelo Brandão Cipolla. São Paulo: Editora WMF Martins Fontes, 2014, p. 565.

${ }^{489}$ DWORKIN, Ronald. A raposa e o porco-espinho: justiça e valor. Tradução de Marcelo Brandão Cipolla. São Paulo: Editora WMF Martins Fontes, 2014, p. 564.

${ }^{490}$ DWORKIN, Ronald. A raposa e o porco-espinho: justiça e valor. Tradução de Marcelo Brandão Cipolla. São Paulo: Editora WMF Martins Fontes, 2014, p. 564-565.

${ }^{491}$ DWORKIN, Ronald. A raposa e o porco-espinho: justiça e valor. Tradução de Marcelo Brandão Cipolla. São Paulo: Editora WMF Martins Fontes, 2014, p. 565-566.
} 
escaparmos da influência do nosso ambiente ético, pois estamos sujeitos a exemplos e celebrações das ideias de outras pessoas sobre como viver, "devemos insistir para que esse ambiente seja criado sob a égide da independência ética", é dizer:

(...) que seja criado organicamente pelas decisões de milhões de pessoas dotadas de autonomia para fazer suas próprias escolhas, não pela imposição arbitrária, a todos, das decisões de uma maioria política. ${ }^{492}$

Dworkin propõe uma interessante imagem: pessoas a nadarem em suas próprias pistas, que podem passar para pistas de outras para lhes auxiliar, mas não para lhes causar danos. A moral, entendida de modo amplo, define as pistas que separam os nadadores. Estipula quando uma pessoa deve atravessar para ajudar e quando o atravessamento é danoso e proibido (seriam os códigos do direito). Já a ética rege o modo como uma pessoa deve nadar na sua própria pista para nadar bem. Essa imagem demonstra os aspectos da moral como anterior à ética na política: "deve ser considerada anterior na definição das oportunidades e recursos que as pessoas têm o direito de ter e, assim, no estabelecimento de seus direitos à liberdade”. A partir dessa concepção interpretativa de liberdade Dworkin afirma ser possível compreender a não subordinação nem da moral à ética nem da ética à moral, já que "elas não competem, mas cooperam entre si”. 493

\section{QUANDO QUESTÕES POLÍTICAS VÃO AOS TRIBUNAIS}

Dworkin enumera algumas questões às quais ele considera questões políticas urgentes: "É justo dar prioridade aos negros em empregos e vagas de universidades? É incivilizado banir filmes sujos, e injusto censurar livros para proteger a segurança nacional? (...) Justiça social significa igualdade econômica? Os juízes devem tomar decisões políticas?" 494 A partir de questões como essas, o jusfilósofo norte-americano reconhece tratar-se da fusão, da interrelação entre problemas práticos com a teoria filosófica, questões de urgência e questões de princípio. Com isso, ele aponta que quando questões políticas vão ao tribunal, elas exigem uma decisão simultaneamente específica e calcada em princípios. ${ }^{495}$

Percebemos, com nitidez, na teoria de Dworkin uma rejeição de que o Direito e a

\footnotetext{
492 DWORKIN, Ronald. A raposa e o porco-espinho: justiça e valor. Tradução de Marcelo Brandão Cipolla. São Paulo: Editora WMF Martins Fontes, 2014, p. 567.

${ }^{493}$ DWORKIN, Ronald. A raposa e o porco-espinho: justiça e valor. Tradução de Marcelo Brandão Cipolla. São Paulo: Editora WMF Martins Fontes, 2014, p. 567-568.

${ }^{494}$ Cf. DWORKIN, Ronald. Uma questão de princípio. Título original: A Matter of Principle. Tradução de Luís Carlos Borges. 2. ed. São Paulo: Martins Fontes, 2005.

${ }^{495}$ Cf. DWORKIN, Ronald. Uma questão de princípio. Título original: A Matter of Principle. Tradução de Luís Carlos Borges. 2. ed. São Paulo: Martins Fontes, 2005.
} 
política possam pertencer a mundos completamente distintos. Mas, além disso, Dworkin também rejeita a opinião diametralmente oposta, segundo a qual o Direito e a política são "exatamente a mesma coisa". Essa última visão ignora o limite crucial do julgamento emitido pelo juiz. Ademais, essa visão "tosca" obscurece a distinção fundamental para a teoria jurídica entre argumentos de política e argumentos de princípios. ${ }^{496}$

Os argumentos de política são argumentos baseados em objetivos. Eles intentam demonstrar que a comunidade estaria melhor, como um todo, se um programa particular fosse seguido. Por outro lado, os argumentos de princípio são argumentos baseados em direitos, destinados ao estabelecimento de um direito individual. ${ }^{497}$

Nesse sentido, a importância da distinção entre os argumentos de princípio e os argumentos de política ganha considerável importância em Dworkin, que sustenta, por exemplo, que os programas de discriminação positiva (como o sistema de quotas) são melhor justificados por argumentos de política, "pelo benefício geral que asseguram ao conjunto da comunidade". Por outro lado, ao discorrer sobre a censura, Dworkin assevera que a defesa da liberdade de expressão encontra guarida em argumentos de princípio. Nessa esteira, Dworkin recorre a "um direito que as pessoas têm à liberdade da escolha sexual e, mais geralmente, a uma independência moral, ainda que suas escolhas não contribuam para melhorar a comunidade como um todo nem mesmo a longo prazo". ${ }^{498}$

Ao analisar o debate em torno da liberdade de imprensa, Dworkin chega à acertada conclusão de que boa parte desse debate foi deturpado "porque aqueles que defendem privilégios especiais para a imprensa oferecem, como argumentos de princípio, o que, na verdade, são argumentos de política". Por derradeiro, o jusfilósofo norte-americano considera errônea a "pressuposta" existência de um direito de saber do público, por não se tratar de um direito, mas de um argumento de política. Ora, "o argumento a favor da livre circulação de informação é um argumento de política: de que a comunidade será beneficiada de várias maneiras se for bem informada". Assim, o conflito entre o "julgamento justo" e a "liberdade de imprensa", não é, nesse caso, um conflito de princípio, "mas antes uma disputa entre um

\footnotetext{
${ }^{496}$ DWORKIN, Ronald. Uma questão de princípio. Título original: A Matter of Principle. Tradução de Luís Carlos Borges. 2. ed. São Paulo: Martins Fontes, 2005, p. 3 e ss; p. 559 e ss. Ver também: DWORKIN, Ronald. Levando os direitos a sério. Tradução: Nelson Boeira, 3.ed. São Paulo: Editora WMF Martins Fontes, 2010, p. 141 e ss.

${ }^{497}$ DWORKIN, Ronald. Uma questão de princípio. Título original: A Matter of Principle. Tradução de Luís Carlos Borges. 2. ed. São Paulo: Martins Fontes, 2005, p. 3 e ss; p. 559 e ss. Ver também: DWORKIN, Ronald. Levando os direitos a sério. Tradução: Nelson Boeira, 3.ed. São Paulo: Editora WMF Martins Fontes, 2010 , p. 141 e ss.

${ }^{498}$ DWORKIN, Ronald. Uma questão de princípio. Título original: A Matter of Principle. Tradução de Luís Carlos Borges. 2. ed. São Paulo: Martins Fontes, 2005, p. 437 e ss.
} 
princípio e a política". Apesar da inegável importância de ambos, salvo raros casos, a disputa deverá ser resolvida a favor do argumento de princípio - a favor do julgamento justo. ${ }^{499}$

Nesse sentido, Dworkin adverte que a confusão criada pelos defensores que intentam expandir a liberdade de imprensa, a partir da combinação entre política e princípio, põe em risco o "genuíno e frágil direito à livre expressão". O risco de comprometer esse direito é maior que os benefícios advindos da política. Confundir os dois é um perigo à liberdade. Dworkin vai além: "A advertência é genérica. Se nos importamos tão pouco com o princípio que emprestamos suas cores à política quando isso serve a nosso propósito, depreciamos o princípio e diminuímos sua autoridade". 500

Nesse cenário, Dworkin propõe a diferenciação entre direitos e objetivos. Não devemos confundir um direito com um objetivo político, "a menos que ele tenha um certo peso contra as metas coletivas em geral", como uma meta de urgência especial. ${ }^{501}$

Eis uma análise que se faz crucial no presente estudo:

\begin{abstract}
Suponhamos que um homem diga que reconhece o direito à liberdade de expressão, mas acrescente que tal liberdade deve ficar em segundo plano sempre que seu exercício possa ser inconveniente para o público. Ele quer dizer, imagino, que reconhece a meta amplamente disseminada do bem-estar coletivo, mas reconhece a distribuição da liberdade de expressão apenas nos termos recomendados por essa meta coletiva para circunstâncias específicas. Sua posição política é exaurida pela meta coletiva; o direito putativo nada acrescenta e não há nenhuma razão para reconhecê-lo como um direito. ${ }^{502}$
\end{abstract}

Esse é um raciocínio que nos permite, com clareza e segurança, afirmar o quanto a liberdade de expressão queda-se diminuída e depreciada se a enxergamos com as cores de argumentos de política, baseados na utilidade geral.

Portanto, diferentemente de uma solução política, uma solução constitucional exige a reflexão em torno de "alguma diferença importante de princípios". ${ }^{503}$ A busca por uma solução constitucional, em detrimento de uma solução política, configura numa exigência de justiça. Vale alertar, assim, “(...) os direitos políticos e morais dos indivíduos muitas vezes dependem de considerações que pessoas diferentes avaliarão de maneira diferente, e, nesse

\footnotetext{
${ }^{499}$ DWORKIN, Ronald. Uma questão de princípio. Título original: A Matter of Principle. Tradução de Luís Carlos Borges. 2. ed. São Paulo: Martins Fontes, 2005, p. 497 e ss.

${ }^{500}$ DWORKIN, Ronald. Uma questão de princípio. Título original: A Matter of Principle. Tradução de Luís Carlos Borges. 2. ed. São Paulo: Martins Fontes, 2005, p. 497 e ss.

${ }^{501}$ DWORKIN, Ronald. Levando os direitos a sério. Tradução: Nelson Boeira, 3.ed. São Paulo: Editora WMF Martins Fontes, 2010, p. 144.

502 DWORKIN, Ronald. Levando os direitos a sério. Tradução: Nelson Boeira, 3.ed. São Paulo: Editora WMF Martins Fontes, 2010, p. 145.

${ }^{503}$ DWORKIN, Ronald. Uma questão de princípio. Título original: A Matter of Principle. Tradução de Luís Carlos Borges. 2. ed. São Paulo: Martins Fontes, 2005, p. 461.
} 
caso, o Direito obteria certeza apenas ao preço de imperfeições e de injustiça”. Por isso, alega Dworkin, o Direito norte-americano - especialmente o Direito constitucional - recusou-se a pagar esse preço e, portanto, tornou-se motivo de inveja de sistemas jurídicos mais formalistas. ${ }^{504}$

Finalmente, devemos alertar que a busca de uma solução constitucional, no lugar de uma solução política, não implica que os juízes não possam proferir decisões que sejam políticas em algum sentido. O que rejeitamos é o uso de fundamentos políticos para a tomada dessas decisões.

\subsection{COMO DECIDEM OS TRIBUNAIS? A ATIVIDADE INTERPRETATIVA DO JUIZ E A TESE DA ÚNICA DECISÃO CORRETA}

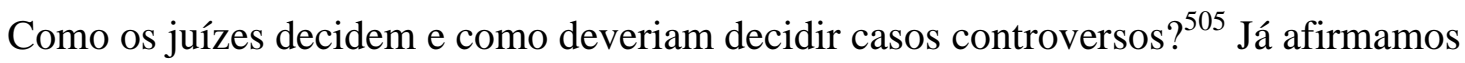
que é natural que as decisões tomadas pelos juízes sejam políticas em algum sentido. Mas vale perguntar: deverão os juízes decidir os casos valendo-se de fundamentos políticos?

Em Taking Rights Seriously ${ }^{506}$, Dworkin tece uma importante distinção entre dois tipos de argumentos políticos dos quais os juízes podem valer-se ao tomar suas decisões: argumentos de princípio político (recorrem aos direitos políticos de cidadãos individuais) e argumentos de procedimento político (exigem que uma decisão particular promova alguma concepção do bem-estar geral ou do interesse público). Destarte, a visão correta, segundo Dworkin, é a de que os juízes devem basear seus julgamentos de casos controversos em argumentos de princípio político, mas não em argumentos de procedimento político.

Faz-se importante relembrar a superação da atividade mecanicista judicial, de modo que a prática dos tribunais democráticos sinaliza para "a quebra do modelo kelseniano do legislador negativo", conforme os ensinamentos de Francisco Segado ${ }^{507}$. No paradigma moderno, sabemos que a jurisdição constitucional rompe de vez com a aplicação robótica do Direito. Inegável é o papel exercido por juízes e tribunais para a vida democrática da sociedade brasileira.

\footnotetext{
${ }^{504}$ DWORKIN, Ronald. Uma questão de princípio. Título original: A Matter of Principle. Tradução de Luís Carlos Borges. 2. ed. São Paulo: Martins Fontes, 2005, p. 466.

${ }^{505}$ DWORKIN, Ronald. Uma questão de princípio. Título original: A Matter of Principle. Tradução de Luís Carlos Borges. 2. ed. São Paulo: Martins Fontes, 2005, p. 3.

${ }^{506}$ DWORKIN, Ronald. Taking Rights Seriously. Cambridge, Mass.: Harvard University Press, 1977; Londres: Duckworth, 1978.

${ }^{507}$ SEGADO, Francisco Fernández. In: Direito Público, Brasília: IDP/Síntese, ano 1, n. o 2, out./dez. 2003 , p. 82.

La Obsolescencia de la Bipolaridad Tradicional (Modelo Americano - Modelo Europeo-Kelseniano) de los

Sistemas de Justicia Constitucional.
} 
Acerca do papel das cortes constitucionais, destaque-se a expressão dworkineana "fórum de princípios" ${ }^{508}$ que, conforme já explicitamos, remete-nos às questões decisivas que devem ser tratadas como questões de princípios, e não como questão de poder político nem de vontade majoritária. Não é demais afirmar que constituem questões de princípio, e não de política, as questões acerca da igualdade racial, da igualdade de gênero, da orientação sexual, dos direitos reprodutivos, do direito do acusado ao devido processo legal, dentre outras. Ademais, acrescente-se que Dworkin reconhece que a compreensão dessas questões, enquanto resultado da transformação exigida pelo fórum de princípios, "não poderá jamais ser integralmente bem-sucedida apenas no âmbito do Legislativo". 509

Portanto, no atual estágio do constitucionalismo, não se pode entregar a concretização dos direitos fundamentais à dependência exclusiva da atuação legislativa, uma vez que os direitos fundamentais constituem a base da comunidade de princípios referida por Dworkin.

Além disso, a força normativa dos princípios no ordenamento jurídico brasileiro encontra amparo no parágrafo $1^{\circ}$ do artigo $5^{\circ}, \mathrm{CF}$, que estabelece expressamente que as normas instituidoras de direito fundamentais têm aplicabilidade imediata.

Ressalte-se que o Judiciário se vale legitimamente de discursos jurídicos, com seu código binário de validade (jurídico/não jurídico), de caráter deontológico.

Não obstante, uma análise em torno de diversos casos julgados do Supremo Tribunal Federal permite-nos apontar que a referida Corte Constitucional, no lugar de uma leitura deontológica, realiza uma leitura axiológica da Constituição Federal, uma vez que, não raramente, opta pela solução de casos a partir da aplicação do chamado princípio da proporcionalidade, utilizando-se, portanto da técnica de ponderação de bens, ou do sopesamento, em sede de controle concentrado de constitucionalidade. ${ }^{510}$

Acatando a doutrina dworkineana, Damião Azevedo realiza severas críticas ao uso do princípio da proporcionalidade para solucionar casos de conflitos entre normas:

\footnotetext{
Se um juiz ou tribunal adota como método essa argumentação orientada por valores mais desejáveis que outros, ele acaba por impor seus próprios valores à sociedade, agindo numa espécie de tutela moral, como se sua condição de julgador lhe atribuísse um papel pedagógico sobe os cidadãos. ${ }^{511}$
}

\footnotetext{
${ }^{508}$ DWORKIN, Ronald. A matter of principle. Harvard University Press, 1985, p. 69-71.

${ }^{509}$ DWORKIN, Ronald. A matter of principle. Harvard University Press, 1985, p. 69-71.

${ }^{510}$ Cite-se, a título de exemplo, ocasiões em que o STF recorreu à teoria valorativa de Alexy, realizando a técnica do sopesamento, como foi o caso do julgamento da ADI 855 MC/PR, Rel. Min. Sepúlveda Pertence, de 01/07/1993, Tribunal Pleno, DJ de 01-10-1993, p. 71 e o julgamento da ADC 9/DF, Rel. Min. Ellen Gracie, de 13/12/2001, Tribunal Pleno, DJ de 23-04-1993, p. 6.

${ }^{511}$ AZEVEDO, Damião Alves de. Ao encontro dos princípios: crítica à proporcionalidade como solução aos casos de conflito aparente de normas jurídicas, Pós-graduação lato sensu em Direito Público, 2008, p. 16. Disponível em: <http://moodle.cead.unb.br/agu/course/view.php?id=9>.
} 
Acrescenta o referido autor que o Estado Democrático de Direito demanda a existência de uma democracia pluralista bem como a convivência entre diferentes formas de vida sem que seja necessário sopesar valores culturais existentes na sociedade, não devendo o juiz substituir os valores das partes pelos seus próprios ou por aquilo que acredita a melhor forma de bem-viver. ${ }^{512}$ Com isso, é possível dizer que, ao utilizar o princípio da proporcionalidade para a solução dos conflitos entre normas, a nossa Corte Constitucional apresenta fundamentos que refletem uma confusão entre a política e Direito, entre argumentos de política e argumentos de princípios, o que compromete a concretização dos trunfos que cada cidadão possui.

Por isso a importância da teoria defendida por Dworkin, onde o caráter deontológico dos princípios é reconhecido e demandado para a solução de cada caso concreto, considerando-se o direito em sua integridade.

Destaque-se que, para Dworkin, a análise jurídica é fundamentalmente interpretativa. Ao apresentar a possibilidade de uma única decisão correta, Dworkin verifica que os céticos (visão comum), que não concordam com essa tese, dirão que existem apenas respostas diferentes para a questão de direito e nenhuma resposta correta, ou melhor. Eles utilizam-se de argumentos como o da submissão dos juízes a instâncias mais representativas, como as legislativas, ou argumentos de que os juízes deverão pautar suas decisões de acordo com $o$ que for melhor para o futuro da nação. ${ }^{513}$

No entanto, o entendimento de que o argumento e a análise jurídica são dotados de caráter interpretativo, esse desafio cético queda-se alterado e minimizado. Assim que o Direito é visto dessa maneira, "há pouco sentido em afirmar ou negar uma verdade objetiva". 514

A tese da única decisão correta é tema central para grandes controvérsias acerca do que é o Direito. A referida tese assenta-se na unicidade e na irrepetibilidade inerentes a cada caso. Esse cenário é figurado pelo modelo de um ordenamento de princípios, onde mesmo as regras devem ser principiologicamente lidas, "que se apresenta por inteiro e, a um só tempo,

\footnotetext{
${ }^{512}$ AZEVEDO, Damião Alves de. Ao encontro dos princípios: crítica à proporcionalidade como solução aos casos de conflito aparente de normas jurídicas, Pós-graduação lato sensu em Direito Público, 2008, p. 17. Disponível em: <http://moodle.cead.unb.br/agu/course/view.php?id=9>.

${ }^{513}$ DWORKIN, Ronald. Uma questão de princípio. Título original: A Matter of Principle. Tradução de Luís Carlos Borges. 2. ed. São Paulo: Martins Fontes, 2005, p. 175 e ss.

${ }^{514}$ DWORKIN, Ronald. Uma questão de princípio. Título original: A Matter of Principle. Tradução de Luís Carlos Borges. 2. ed. São Paulo: Martins Fontes, 2005, p. 175 e ss.
} 
composto por princípios opostos em produtiva tensão". 515 O ordenamento principiológico é complexamente formado por princípios reciprocamente constitutivos e igualmente válidos, que, por derradeiro, dependem do caso concreto. Essa leitura nos permite discernir a pretensões abusivas da correta.

À tese da única decisão correta circundam importantes fatores:

\begin{abstract}
Por isso mesmo, o caso em sua concretude e irrepetibilidade deve ser reconstruído de todas as perspectivas possíveis, consoante as próprias pretensões a direito levantadas, no sentido de se alcançar a norma adequada, a única capaz de produzir justiça naquele caso específico. Essas reflexões de Dworkin marcam o emergir de um novo paradigma que vem, enquanto tal, de forma cada vez mais difundida e internalizada se afirmando através da constituição de um novo senso comum social, de um novo pano-de-fundo para a comunicação social, no qual são gestadas pretensões e expectativas muito mais complexas, profundas e rigorosas no que respeita ao projeto de reencantamento com o Direito, seja como ordenamento ou esfera própria da ação comunicativa, do reconhecimento e do entendimento mútuo dos cidadãos para o estabelecimento e a implementação da normativa que deve reger sua vida em comum, seja como simples âmbito específico de conhecimento e exercício profissionais. É esse novo paradigma que tem sido denominado pela Doutrina "Estado Democrático de Direito" e que, no Brasil, foi inclusive constitucionalmente consagrado. ${ }^{516}$
\end{abstract}

A exigência apontada por Dworkin de que o juiz deve buscar a única decisão correta longe está de reduzir o intérprete a recorrer a mandamentos escritos a priori, mas, pelo contrário, busca-se a postura a ser assumida em face das questões aparentemente nãoreguladas, apresentadas enquanto hard cases, "de densificação dos sentidos abstratos em face de um compartilhamento existente, embora sempre passível de ser problematizado e polemizado, do sentido vivencial dos princípios jurídicos" ${ }^{\$ 517}$, inerente à comunidade de princípios.

Por sua vez, Robert Alexy, releva-nos sua incompreensão diante da tese da única resposta correta, já que, para ele, ela pressupõe um consenso. Ora, a única resposta correta não depende de um real consenso sobre a sua correção, mas de uma postura hermenêutica diante do caso, que será regida pela comunidade principiológica exigida pela sociedade. ${ }^{518}$ Nesse sentido, vale mencionar a proposta dworkineana:

\footnotetext{
${ }^{515}$ CARVALHO NETTO, Menelick de; SCOTTI, Guilherme. Os Direitos Fundamentais e a (in)certeza do Direito: a produtividade das tensões principiológicas e a superação do sistema de regras. Belo Horizonte: Editora Fórum, 2011, p. 9.

${ }^{516}$ CARVALHO NETTO, Menelick de; SCOTTI, Guilherme. Os Direitos Fundamentais e a (in)certeza do Direito: a produtividade das tensões principiológicas e a superação do sistema de regras. Belo Horizonte: Editora Fórum, 2011, p. 9.

${ }^{517}$ CARVALHO NETTO, Menelick de; SCOTTI, Guilherme. Os Direitos Fundamentais e a (in)certeza do Direito: a produtividade das tensões principiológicas e a superação do sistema de regras. Belo Horizonte: Editora Fórum, 2011, p. 9 e ss.

${ }^{518}$ CARVALHO NETTO, Menelick de; SCOTTI, Guilherme. Os Direitos Fundamentais e a (in)certeza do Direito: a produtividade das tensões principiológicas e a superação do sistema de regras. Belo Horizonte: Editora Fórum, 2011, p. 50 e ss.
} 
Essa teoria não defende que exista qualquer procedimento mecânico que demonstre quais são os direitos das partes nos casos difíceis. Pelo contrário, o argumento supõe que juristas e juízes razoáveis irão muitas vezes divergir sobre os direitos, assim como cidadãos e políticos divergem sobre questões políticas. [Essa discussão] descreve as questões que juízes e juristas devem colocar para si próprios, mas isso não garante que todos eles darão a mesma resposta a essas questões. ${ }^{519}$

\title{
2.2 QUAL LUGAR OCUPA O DIREITO À LIVRE EXPRESSÃO? LIBERDADE DE EXPRESSÃO E O HATE SPEECH
}

\subsubsection{Considerações gerais}

No cenário brasileiro, encontramos decisões do STF que apontam a posição de destaque conferida à liberdade de expressão, como é o caso do já mencionado julgamento da ADI n. $4.815^{520}$, de relatoria da Ministra Carmen Lúcia. Em seu respeitável voto, ela reconheceu o acolhimento desse direito por todos os sistemas constitucionais democráticos, e asseverou que a atualidade expõe desafios novos quanto ao exercício desse direito. Ademais, “(...) em toda a história da humanidade, o que se tem como fio condutor de lutas de direitos fundamentais é exatamente a liberdade de expressão (...). Quem, por direito, não é senhor do seu dizer não se pode dizer senhor de qualquer direito". 521

Lembre-se, também, das considerações de J.J. Gomes Canotilho, para o qual:

\begin{abstract}
A liberdade de expressão permite assegurar a continuidade do debate intelectual e do confronto de opiniões, num compromisso crítico permanente. Com essa qualidade, ela integra o sistema constitucional de direitos fundamentais, deduzindo-se do valor da dignidade da pessoa humana e dos princípios gerais de liberdade e igualdade, juntamente com a inerente exigência de proteção jurídica. A liberdade de expressão em sentido amplo é um direito multifuncional, que se desdobra num cluster de direitos comunicativos fundamentais (Kommunikationsgrudrechte) que dele decorrem naturalmente, como seja, por exemplo, a liberdade de expressão stricto sensu, de informação, de investigação acadêmica, de criação artística, de edição, de jornalismo, de imprensa, de radiodifusão, de programação, de comunicação individual, de telecomunicação e comunicação em rede. ${ }^{522}$
\end{abstract}

\footnotetext{
${ }^{519}$ DWORKIN, Ronald. Levando os direitos a sério. Tradução: Nelson Boeira, 3.ed. São Paulo: Editora WMF Martins Fontes, 2010, p. 127 e ss.

${ }^{520} \mathrm{Na}$ referida decisão, por unanimidade, o Plenário do Supremo Tribunal Federal julgou procedente a Ação Direta de Inconstitucionalidade (ADI) 4815-DF e declarou inexigível a autorização prévia para a publicação de biografias. Seguindo o voto da relatora, ministra Cármen Lúcia, "a decisão dá interpretação conforme a Constituição da República aos artigos 20 e 21 do Código Civil, em consonância com os direitos fundamentais à liberdade de expressão da atividade intelectual, artística, científica e de comunicação, independentemente de censura ou licença de pessoa biografada, relativamente a obras biográficas literárias ou audiovisuais (ou de seus familiares, em caso de pessoas falecidas)".

${ }^{521}$ SUPREMO TRIBUNAL FEDERAL. Ação Direta de Inconstitucionalidade n. 4.815 - Distrito Federal. Relatora: Min. Carmen Lúcia. Disponível em: < http://www.stf.jus.br/arquivo/cms/noticiaNoticiaStf/anexo/ADI4815relatora.pdf >. Acesso em 26 mai.2015. ${ }^{522}$ CANOTILHO, J. J. Gomes; MACHADO, Jónatas E. M.. Constituição e código civil brasileiro: âmbito de proteção de biografias não autorizadas. In: JÚNIOR, Antônio Pereira Gaio; SANTOS, Márcio Gil Tostes
} 
É importante destacar a relação de interdependência que assumem a liberdade de expressão e o "megaprincípio" 523 da democracia. De acordo com a doutrina do jurista alemão Martin Kriele,

Os direitos fundamentais e a democracia se dão numa relação de condicionamento mútuo: a democracia pressupõe liberdade individual protegida juridicamente para todos; a liberdade para todos pressupõe democracia. Este fato é de grande importância para a interpretação dos direitos fundamentais. Se se separa a conexão entre liberdade e democracia, chega-se a uma interpretação dos direitos capaz de pôr em perigo tanto a liberdade como a democracia (...). O Estado constitucional democrático aparece como um feixe de compromissos entre ideias opostas entre si. $^{524}$

Para a doutrina de Ingo Sarlet, a liberdade de manifestação do pensamento e a liberdade de expressão, compreendidas em conjunto, configuram-se como:

(...) os direitos fundamentais mais preciosos e correspondem a uma das mais antigas exigências humanas, de tal sorte que integram os catálogos constitucionais desde a primeira fase do constitucionalismo moderno. Assim como a liberdade de expressão e manifestação do pensamento encontra um dos seus principais fundamentos (e objetivos) na dignidade da pessoa humana, naquilo que diz respeito à autonomia e ao livre desenvolvimento da personalidade do indivíduo, ela também guarda relação, numa dimensão social e política, com as condições e a garantia da democracia e do pluralismo político, assegurando uma espécie de livre mercado das ideias, assumindo, neste sentido, a qualidade de um direito político e revelando ter também uma dimensão nitidamente transindividual, já que a liberdade de expressão e os seus respectivos limites operam essencialmente na esfera das relações de comunicação e da vida social. $(\ldots)^{525}$

Nesse sentido, o mencionado autor ${ }^{526}$ defende que o desempenho da função dessa liberdade numa ordem democrática e plural pressupõe que, no que tange ao seu âmbito de proteção, a liberdade de expressão englobe "um conjunto diferenciado de situações", agasalhando, em princípio, uma série de liberdades (faculdades) de conteúdo espiritual, incluindo expressões não verbais, por exemplo. Por derradeiro, em se tratando de liberdade de expressão, há que se destacar, em especial, a liberdade de exprimir opiniões, os juízos de

dos. Constituição Brasileira de 1988. Reflexões em comemoração ao seu $25^{\circ}$ aniversário. Curitiba: Juruá, 2014, p. 132.

${ }^{523}$ Expressão utilizada pela doutrina de Carlos Ayres Britto, para o qual “a Democracia está no centro dos princípios constitucionais, tanto quanto os princípios constitucionais estão no centro da Constituição e a Constituição está no centro do Sistema Jurídico". Cf. BRITTO, Carlos Ayres. Teoria da Constituição. Rio de Janeiro: Forense, 2003, p. 183.

${ }^{524}$ KRIELE, Martin. Introducción a la teoría del Estado. Fundamentos históricos de la Legitimidad del Estado Constitucional Democrático. Traducción por Eugenio Bulygin. Buenos Aires: De Palma, 1980.

${ }^{525}$ SARLET, Ingo Wolfgang. Direitos Fundamentais em espécie. In: SARLET, Ingo Wolfgang, MARINONI, Luiz Guilherme. MITIDIERO, Daniel. Curso de Direito Constitucional. 3.ed. São Paulo: Revista dos Tribunais, 2014. p. 446 e ss.

${ }^{526}$ SARLET, Ingo Wolfgang. Direitos Fundamentais em espécie. In: SARLET, Ingo Wolfgang, MARINONI, Luiz Guilherme. MITIDIERO, Daniel. Curso de Direito Constitucional. 3.ed. São Paulo: Revista dos Tribunais, 2014. p. 446 e ss. 
valor a respeito de fatos, de ideias, bem como os juízos de valor sobre opiniões de terceiros etc. Portanto,

(...) assim é a liberdade de opinião que se encontra na base de todas as modalidades da liberdade de expressão, de modo que o conceito de opinião (que, na linguagem da Constituição Federal, acabou sendo equiparado ao de pensamento) há de ser compreendido em sentido amplo, de forma inclusiva, abarcando também, apenas para deixar mais claro, manifestações a respeito de fatos e não apenas juízos de valor. ${ }^{527}$

Acrescenta, ainda o autor que além da proteção do conteúdo, isto é, do objeto da expressão, também encontram proteção os meios de expressão, que, por sinal, consiste numa noção aberta, portanto inclusiva de novas modalidades, como é o caso da comunicação eletrônica. O referido autor afirma, com insistência, a necessidade de amplitude do âmbito de proteção que se deve conferir à liberdade de expressão, que se direciona a agasalhar “(...) tanto a manifestação de opiniões, quanto de ideias, pontos de vista, convicções, críticas, juízos de valor sobre qualquer matéria ou assunto e mesmo proposições a respeito de fatos”, assim como "gestos, sinais, movimentos, mensagens orais e escritas, representações teatrais, sons, imagens, (...) manifestações veiculadas pelos modernos meios de comunicação (...)". 528

Neste sentido, para Ingo Sarlet, podemos resumir que a liberdade de expressão destina-se a proteger todas as formas de manifestação, desde que não violentas. ${ }^{529}$ Acrescenta o autor que devido a sua relevância para a democracia e o pluralismo político, a liberdade de expressão "assume uma espécie de posição preferencial (preferred position), quando da resolução de conflitos com outros princípios constitucionais e direitos fundamentais", muito embora a teoria da posição preferencial - em que pese consagrada pelo STF quando do julgamento da ADPF 130 — tem sido, em geral, aplicada de forma tímida. ${ }^{530}$

Não obstante a liberdade de expressão ocupe essa posição, a ela não se deve conferir “(...) a condição de direito absolutamente imune a qualquer limite e restrição, nem de estabelecer uma espécie de hierarquia prévia entre as normas constitucionais". À teoria da posição preferencial da liberdade de expressão, no Brasil, pode-se relacionar a finalidade de

\footnotetext{
${ }^{527}$ SARLET, Ingo Wolfgang. Direitos Fundamentais em espécie. In: SARLET, Ingo Wolfgang, MARINONI, Luiz Guilherme. MITIDIERO, Daniel. Curso de Direito Constitucional. 3.ed. São Paulo: Revista dos Tribunais, 2014. p. 446 e ss.

${ }^{528}$ SARLET, Ingo Wolfgang. Direitos Fundamentais em espécie. In: SARLET, Ingo Wolfgang, MARINONI, Luiz Guilherme. MITIDIERO, Daniel. Curso de Direito Constitucional. 3.ed. São Paulo: Revista dos Tribunais, 2014. p. 446 e ss.

${ }^{529}$ SARLET, Ingo Wolfgang. Direitos Fundamentais em espécie. In: SARLET, Ingo Wolfgang, MARINONI, Luiz Guilherme. MITIDIERO, Daniel. Curso de Direito Constitucional. 3.ed. São Paulo: Revista dos Tribunais, 2014. p. 446 e ss.

${ }^{530}$ SARLET, Ingo Wolfgang. Direitos Fundamentais em espécie. In: SARLET, Ingo Wolfgang, MARINONI, Luiz Guilherme. MITIDIERO, Daniel. Curso de Direito Constitucional. 3.ed. São Paulo: Revista dos Tribunais, 2014. p. 446 e ss.
} 
reconhecer a essa liberdade uma posição de vantagem no caso de conflitos com outros bens fundamentais no que diz com a hierarquização das posições conflitantes no caso concreto. ${ }^{531}$

\subsubsection{Temos um direito ao hate speech?}

Os Estados Unidos sempre enfrentaram o incômodo tema do discurso do ódio (hate speech), que pode ser compreendido como o discurso destinado a promover o ódio ou a aversão, por razões de sexo, origem étnica, nacionalidade ou religião. Esses discursos podem tomar a forma de palavras faladas, mensagens escritas, gestos ou outras modalidades de atos que insultam ou intimidam pessoas ou grupos, o que estimula a violência. Nesse cenário, a Suprema Corte norte-americana tem conferido ampla proteção à liberdade de expressão, declarando a inconstitucionalidade das leis que procuraram restringir essa liberdade devido a inadequabilidade e na ofensa desses atos. De acordo com a Suprema Corte, a democracia pressupõe a proteção de todas as formas de expressão e, por conseguinte, a garantia de um debate aberto, vigoroso e desinibido. ${ }^{532}$

A concepção de liberdade (liberty), em Dworkin, pode ser justificada por três tipos de argumento: (1) Necessitamos de algumas liberdades, particularmente, a liberdade de expressão (liberty of speech), pois liberdades desse tipo são necessárias a um justo e adequado sistema democrático de governo. (2) O direito à independência ética, que decorre do primado do igual respeito à responsabilidade dos cidadãos. Temos o direito de realizar escolhas fundamentais, por conta própria, sem interferência do Estado, sobre o significado e importância da vida humana, por exemplo. (3) O direito também baseado na independência ética, de não ter negada qualquer autonomia (freedom) quando a justificação do Estado repousar na popularidade ou na superioridade de algumas concepções sobre um modo melhor de vida a ser seguido. ${ }^{533}$

O direito à livre expressão ocupa lugar central na teoria tradicional dos direitos liberais e deve, para Dworkin, "ser tratado com mais sutileza". No âmbito estadunidense, os especialistas em direito constitucional aceitam majoritariamente que a proibição dirigida ao Estado de limitar a liberdade de expressão (freedom of speech) constante na Primeira Emenda

\footnotetext{
${ }^{531}$ SARLET, Ingo Wolfgang. Direitos Fundamentais em espécie. In: SARLET, Ingo Wolfgang, MARINONI, Luiz Guilherme. MITIDIERO, Daniel. Curso de Direito Constitucional. 3.ed. São Paulo: Revista dos Tribunais, 2014. p. 446 e ss.

${ }^{532}$ A nível de jurisprudência norte-americana, vale mencionar a famosa decisão acerca do caso Ku Klux Klan, em Brandenburg vs. Ohio, julgado em 1969.

${ }^{533}$ DWORKIN, Ronald. Justice for Hedgehogs. Keynote address. In: Boston University, p. 471-472. Disponível em: < http://www.bu.edu/law/journals-archive/bulr/documents/dworkin_k.pdf>. Acesso em 15 fev. 2015.
} 
encontra justificação em diversos princípios e finalidades. Uma dessas justificativas baseia-se na liberdade positiva. A liberdade de expressão deve englobar qualquer concepção plausível do autogoverno por, no mínimo, duas concepções importantes:

(...) o autogoverno pressupõe o livre acesso à informação; e nenhum governo será legitimo, e portanto não terá o direito moral de exercer coerção, a menos que todos o s que sofram coerção tenham tido a oportunidade de influenciar as decisões coletivas. $^{534}$

Em "Virtude Soberana", Dworkin atenta para a importância da liberdade de expressão no contexto de organização social democrática, ao reconhecer que a soberania popular demanda que o povo tenha o poder final do Estado e que "uma estrutura constitucional que garante a liberdade de expressão contra a censura oficial protege os cidadãos em seu papel democrático como soberanos". Enquanto complementar à concepção de igualdade, a liberdade de expressão "resulta essencial para a associação democrática", devendo ser garantido o direito de se expressar qualquer opinião relevante, sem se importar se ditas opiniões são rechaçadas, odiadas ou temidas por outros cidadãos. ${ }^{535}$

Nesse sentido, Dworkin afirma que leis que proíbam marchas de neonazistas, por exemplo, "desfiguram a democracia", uma vez que se uma maioria de cidadãos tem o poder de negar a um concidadão o direito de falar quando considere que suas ideias resultam perigosas ou ofensivas, "então este não é um igual na competição argumentativa do poder". Por derradeiro, deve-se permitir que todos os cidadãos que estão submetidos às leis possuam voz igual no processo que as produz, "ainda quando temos razões para detestar suas convicções ou quando sacrifiquemos nosso direito a impor nossas leis sobre eles". 536

Em sua última obra "Religion Without God"537, Dworkin destaca: "A just state must recognize both a very general right to what we call 'ethical independence' and also special rights to particular liberties". Como já foi dito, a independência ética significa que o Estado jamais deverá restringir a liberdade amparado no argumento de que um determinado modo de vida seja intrinsecamente melhor que outro, não porque as consequências desse determinado

\footnotetext{
${ }^{534}$ DWORKIN, Ronald. A raposa e o porco-espinho: justiça e valor. Tradução de Marcelo Brandão Cipolla. São Paulo: Editora WMF Martins Fontes, 2014, p. 570.

${ }^{535}$ DWORKIN, Ronald. Virtud Soberana. La teoría y la práctica de la igualdad. Traducción de Fernando Aguiar y de María Julia Bertomeu. Barcelona: Ediciones Paidós Ibérica S.A., 2003, p. 396-397.

${ }_{536}$ DWORKIN, Ronald. Virtud Soberana. La teoría y la práctica de la igualdad. Traducción de Fernando Aguiar y de María Julia Bertomeu. Barcelona: Ediciones Paidós Ibérica S.A., 2003, p. 396-397.

${ }^{537}$ A última obra de Dworkin analisou que "freedom of religion should flow not from a respect for belief in God but from the right to ethical independence." Religion without God is the work of a humanist who recognized both the possibilities and limitations of humanity. Cf. DWORKIN, Ronald. Religion without god. Cambridge, Mass.: Harvard University Press, 2013.
} 
modo de vida sejam melhores, mas porque pessoas que vivem dessa forma (da forma melhor) são pessoas melhores. Nesse sentido, Dworkin prossegue: “In a state that prizes freedom, it must be left to individual citizens, one by one, to decide such questions for themselves, not up to government to impose one view on everyone". Por isso, o Estado não pode proibir o uso de drogas somente porque acredita que isso seja vergonhoso, nem pode aumentar os impostos devido ao fato de o materialismo ser maléfico, por exemplo. ${ }^{538}$

Mas isso não implica que o Estado não possa interferir nas escolhas de vida das pessoas por outros motivos. Ao contrário, o Estado deve proteger as pessoas de danos, deve fornecer o bem-estar geral, por exemplo. Nesse sentido, a proibição ao uso de drogas encontra sentido se é realizada com base na proteção da comunidade contra os custos sociais do vício, e, a cobrança de impostos pode fundamentar-se na ajuda aos pobres ou no financiamento de estradas, por exemplo. ${ }^{539}$ Portanto, a independência ética serve como escudo frente às restrições estatais somente por algumas justificativas.

Por outro lado, existem "special rights" que impõem restrições muito mais poderosas ao Estado. Aqui, encontramos a liberdade de expressão, sendo que "government may not infringe that special freedom unless it has what American lawyers have come to call a 'compelling' justification”. Aqueles que se expressam não devem sofrer censura até mesmo quando o que eles falam possa trazer más consequências para outros. ${ }^{540}$

Mas então, perguntamos: qual o limite da liberdade de expressão para a doutrina dworkineana? O direito à livre expressão poderá ser abreviado somente em situações emergenciais, a saber: para prevenir um perigo claro, presente e grave. ${ }^{541}$

A concepção dworkineana inevitavelmente agasalha os direitos dos detestáveis. A censura ao livre discurso do ódio configura, sob a ótica de Dworkin, a violação da independência ética. Dworkin ressalta como vários fatores interagem quando o Estado tenta proibir as expressões de ódio. Ele menciona a famosa decisão de um tribunal de Ohio, que condenou criminalmente um líder da Ku Klux Klan devido ao fato de ele defender o ódio contra negros e os judeus. Para Dworkin, a lei, como foi interpretada, violou seu direito à liberdade positiva - porque o proibia de tentar convocar outros a adotar suas ideias políticas, assim como sua independência ética, uma vez que "o direito de dar testemunho público das próprias convicções políticas é fundamental e a violência por ele pregada não era iminente". Violava também a sua independência ética de outro modo, por restar provável que o processo

\footnotetext{
${ }^{538}$ DWORKIN, Ronald. Religion without god. Cambridge, Mass.: Harvard University Press, 2013, p. 130.

${ }^{539}$ DWORKIN, Ronald. Religion without god. Cambridge, Mass.: Harvard University Press, 2013, p. 131.

${ }^{540}$ DWORKIN, Ronald. Religion without god. Cambridge, Mass.: Harvard University Press, 2013, p. 131.

${ }^{541}$ DWORKIN, Ronald. Religion without god. Cambridge, Mass.: Harvard University Press, 2013, p. 131-132.
} 
motivou-se não pelo medo da violência, "mas pela aversão - inteiramente justificada - à baixa estima que ele tinha pela importância de certas vidas”. Posteriormente, a Suprema Corte reformou a condenação. Dworkin menciona esse caso “(...) para mostrar como aspectos tanto da liberdade positiva quanto da liberdade negativa confluem honrosamente para proteger os direitos dos detestáveis". ${ }^{542}$

Determinar até que ponto as pessoas têm o direito de fazer algo errado consiste em um problema antigo da teoria liberal. "Os liberais insistem em que as pessoas têm o direito legal de dizer o que desejam em matéria de controvérsia política ou social”. Contudo, indaga Dworkin: essas pessoas devem ser livres para incitar o ódio racial, por exemplo? ${ }^{543}$

Ao discorrer acerca de um possível direito à pornografia e de suas restrições, Dworkin enumera duas estratégias permissivas diferentes: ${ }^{544}$ (1) A estratégia "baseada no objetivo": mesmo que a publicação e consumo da pornografia sejam prejudiciais à comunidade como um todo, considerada por si só, as consequências de tentar censurar ou suprimir a pornografia seriam, a longo prazo, muito piores. (2) A estratégia "baseada nos direitos": ainda que a pornografia piore a situação da comunidade, mesmo a um prazo muito longo, é errado censurá-la ou restringi-la, "pois isso viola os direitos morais e políticos individuais dos cidadãos que se indignam com a censura". 545

Posteriormente, Dworkin analisa o relatório do Comitê sobre a obscenidade e a censura de filmes - Relatório Williams, de 1979, Londres. Não obstante o Relatório rejeite algumas ideias de John Stuart Mill no que tange às condições mais propícias para a descoberta da verdade, ele aceita algo muito próximo da teoria especial sobre o valor geral da livre expressão, de John Stuart Mill (Da Liberdade). Mill "sugere que a sociedade tem mais chance de descobrir a verdade, não apenas na ciência mas também a respeito das melhores condições para a prosperidade humana, quando tolera o livre mercado de ideias”. O Relatório expõe a ideia de que "a livre expressão é essencial não apenas como um meio para o desenvolvimento humano, mas como parte dele". 546

Destarte, o Relatório reconhece o valor geral da livre expressão, de forma que tal valor

\footnotetext{
${ }^{542}$ DWORKIN, Ronald. A raposa e o porco-espinho: justiça e valor. Tradução de Marcelo Brandão Cipolla. São Paulo: Editora WMF Martins Fontes, 2014, p. 570-571.

${ }^{543}$ DWORKIN, Ronald. Uma questão de princípio. Título original: A Matter of Principle. Tradução de Luís Carlos Borges. 2. ed. São Paulo: Martins Fontes, 2005, p. 497.

${ }^{544}$ DWORKIN, Ronald. Uma questão de princípio. Título original: A Matter of Principle. Tradução de Luís Carlos Borges. 2. ed. São Paulo: Martins Fontes, 2005, p. 498.

${ }^{545}$ DWORKIN, Ronald. Uma questão de princípio. Título original: A Matter of Principle. Tradução de Luís Carlos Borges. 2. ed. São Paulo: Martins Fontes, 2005, p. 498 e ss.

${ }^{546}$ Relatório, p. 55 apud DWORKIN, Ronald. Uma questão de princípio. Título original: A Matter of Principle. Tradução de Luís Carlos Borges. 2. ed. São Paulo: Martins Fontes, 2005, p. 500.
} 
requer um pressuposto contra a censura ou proibição da atividade que expressa uma convicção sobre um determinado modo de viver ou de sentir, ou quando se opõe a convicções difundidas. Todavia, reconhece também que esse pressuposto não é absoluto, podendo ser superado a partir da demonstração de um grave e incontroverso prejuízo que a atividade ameaça produzir. Lembra que o pressuposto a ser superado deve ser forte, todavia, para que se possa proteger o objetivo de longo prazo de assegurar as melhores condições ao nosso alcance para o desenvolvimento humano. ${ }^{547}$

A essa estratégia Dworkin chama de Estratégia Williams. O Relatório confere um tratamento diferente aos diferentes tipos de pornografia, buscando um equilíbrio, na medida em que restringe certas formas de pornografia mais que outras. Ao discorrer sobre a questão de cenas de sexo ao vivo em espetáculos públicos, Dworkin explica que tal fato não implicaria em um rompimento da importante distinção entre o público e o privado. Embasa seu argumento nos diálogos culturais traçados ao longo do tempo, dando como exemplo os hábitos que as pessoas têm de comer na rua, de se beijarem e de se abraçarem em público, além da permissão de andarem nuas em determinadas praias públicas. São hábitos que, em outro tempo, pertenciam muito mais ao âmbito privado.

Nesse sentido, Dworkin, brilhantemente, aborda a questão produtiva entre o público e o privado, mais uma vez:

Com certeza, as dimensões e contornos do espaço público pertencem adequadamente ao diálogo, por meio de exemplo, a respeito das possibilidades do desenvolvimento humano, o diálogo que a estratégia Williams deseja proteger. A vitalidade e o caráter da distinção básica, a ideia básica de que deve existir um espaço privado, é mais ameaçada por um congelamento legalmente imposto das fronteiras estabelecidas em qualquer tempo específico do que permitindo que o mercado da expressão reexamine e redesenhe essas fronteiras constantemente. ${ }^{548}$

Ainda nesse cenário, Dworkin indaga:

Se o direito à liberdade é o direito de uma pessoa de não ter sua liberdade limitada simplesmente porque outros sentem nojo do que ela se propõe fazer, por que esse direito não inclui o direito de fazer o que quer em público, livre da possível ofensa da maioria ao presenciá-lo? ${ }^{549}$

Lembremos ainda que “(...) a proteção de uma esfera privada, o reconhecimento de um direito individual a esse tipo de privacidade, reduz o poder das pessoas em geral de pôr em

\footnotetext{
${ }^{547}$ DWORKIN, Ronald. Uma questão de princípio. Título original: A Matter of Principle. Tradução de Luís Carlos Borges. 2. ed. São Paulo: Martins Fontes, 2005, p. 501.

${ }^{548}$ DWORKIN, Ronald. Uma questão de princípio. Título original: A Matter of Principle. Tradução de Luís Carlos Borges. 2. ed. São Paulo: Martins Fontes, 2005, p. 510-11.

${ }^{549}$ DWORKIN, Ronald. Uma questão de princípio. Título original: A Matter of Principle. Tradução de Luís Carlos Borges. 2. ed. São Paulo: Martins Fontes, 2005, p. 515.
} 
prática suas próprias ideias a respeito das melhores circunstâncias para a prosperidade humana". 550

Acrescente-se, ainda, que o conceito de um direito à privacidade pertence, portanto, não à classe das estratégias baseadas em objetivos, mas à classe muito diferente das estratégias baseadas em direitos, porque esse conceito argumenta que as pessoas devem ter uma esfera privada, "mesmo que isso prejudique, em vez de promover, os objetivos a longo prazo da sociedade e, portanto, conceda à maioria das pessoas menos controle efetivo sobre o planejamento de seu ambiente". 551

Dworkin assevera que é preciso um argumento positivo no sentido de que a liberdade de escolha individual (de ler ou não romances sádicos, por exemplo) "é uma condição essencial ou altamente desejável para a prosperidade humana ${ }^{552}$. Ou, pelo menos, de que é uma condição indesejável dizer às pessoas que querem essas coisas que elas não podem fazê$10 " .553$

Os argumentos dworkineanos apontam para uma "fraqueza geral dos argumentos baseados em objetivos", que se tornam evidentes quando usados na defesa de uma postura liberal perante a pornografia, ou mesmo quando usados em favor da proteção de outras atividades impopulares como, por exemplo, “o discurso político espúrio ou odioso". ${ }^{554}$ Ora, “nossas convicções a respeito da liberdade de expressão não são provisórias, mornas nem marginais". ${ }^{555}$ São mais que convicções. Na verdade, Dworkin busca um argumento que atenda às estratégias baseadas em direitos, e não em objetivos. Mas no que consiste um argumento desse tipo?

$\mathrm{O}$ argumento proposto por Dworkin é o de que temos um direito à independência ética, e quem recorre a esse direito não se ampara na justificativa de um bem-estar geral da comunidade a longo prazo. Mas qual a força desse direito? Esse direito configura uma limitação poderosa para a regulamentação de uma liberdade.

Do mesmo modo que livros pornográficos poderiam incitar crimes de violência sexual

\footnotetext{
${ }^{550}$ DWORKIN, Ronald. Uma questão de princípio. Título original: A Matter of Principle. Tradução de Luís Carlos Borges. 2. ed. São Paulo: Martins Fontes, 2005, p. 520.

${ }^{551}$ DWORKIN, Ronald. Uma questão de princípio. Título original: A Matter of Principle. Tradução de Luís Carlos Borges. 2. ed. São Paulo: Martins Fontes, 2005, p. 520.

${ }_{552}$ Nota minha: lembre que essa questão do benefício da prosperidade humana foi incansavelmente debatida e incitada por John Stuart Mill, conforme vimos neste texto, anteriormente.

${ }^{553}$ DWORKIN, Ronald. Uma questão de princípio. Título original: A Matter of Principle. Tradução de Luís Carlos Borges. 2. ed. São Paulo: Martins Fontes, 2005, p. 522.

${ }^{554}$ DWORKIN, Ronald. Uma questão de princípio. Título original: A Matter of Principle. Tradução de Luís Carlos Borges. 2. ed. São Paulo: Martins Fontes, 2005, p. 523.

${ }^{555}$ DWORKIN, Ronald. Uma questão de princípio. Título original: A Matter of Principle. Tradução de Luís Carlos Borges. 2. ed. São Paulo: Martins Fontes, 2005, p. 523.
} 
ou um deletério sobre a economia geral, por causar absenteísmo no trabalho, livros de Shakespeare e a Bíblia também poderiam gerar essas infelizes consequências. Mas estes últimos são amplamente aceitos pela comunidade, que os compreende como aceitáveis dentro de um parâmetro do bem viver.

Com relação ao alcance das liberdades por meio da independência ética, Dworkin assevera: "O processo de tornar um direito abstrato sucessivamente mais concreto não é simplesmente um processo de dedução ou interpretação da formulação abstrata, mas um novo passo na teoria política". ${ }^{556}$ Não se trata, portanto, de encontrar um algoritmo para um direito acerca da obscenidade, da liberdade, de um direito abstrato, mas de encontrar uma “concepção concreta plausível de um direito abstrato" que seja capaz de oferecer um esquema sensato de regulamentação. ${ }^{557}$

Dworkin faz menção a uma crítica a ele dirigida por H. L. A. Hart, que, por sua vez, afirma que a fraqueza do argumento dworkineano, que o torna "fundamentalmente errado", é a de presumir que se a liberdade de alguém sofre restrição, isso deve ser interpretado como uma negação de igual tratamento. ${ }^{558}$ Dessa forma, Hart compreende que, a partir da formulação dworkineana, a negação da liberdade é interpretada como a negação da igual consideração e respeito. No entanto, Dworkin ressalva que nem sempre isso é assim, mas tão somente "quando a justificativa da restrição se apoia, de alguma maneira, no fato de outros condenarem as convicções ou valores daquela pessoa". 559

Portanto, a justificativa utilitarista não logra encontrar sucesso sem recorrer "às preferências moralistas sobre como a minoria deve viver, e o Estado, não obstante, insiste nessa justificativa", formando uma imagem de atuação política, para Dworkin, repulsiva. ${ }^{560}$ Trata-se, afinal, de uma imposição ao sofrimento impingida pela maioria sobre a minoria - e como ela deve viver. Incompatível, portanto, com uma sociedade comprometida em conferir às pessoas o tratamento igualitário.

O que busca Dworkin é:

(...) desenvolver uma teoria de direitos que seja relativa aos outros elementos de uma teoria política e examinar até que ponto essa teoria pode ser elaborada a partir da

\footnotetext{
${ }^{556}$ DWORKIN, Ronald. Uma questão de princípio. Título original: A Matter of Principle. Tradução de Luís Carlos Borges. 2. ed. São Paulo: Martins Fontes, 2005, p. 531.

${ }^{557}$ DWORKIN, Ronald. Uma questão de princípio. Título original: A Matter of Principle. Tradução de Luís Carlos Borges. 2. ed. São Paulo: Martins Fontes, 2005, p. 531.

${ }^{558}$ HART, H.L.A. Law, Liberty, and Morality. Stanford University Press, 1963, p. 842.

${ }^{559}$ DWORKIN, Ronald. Uma questão de princípio. Título original: A Matter of Principle. Tradução de Luís Carlos Borges. 2. ed. São Paulo: Martins Fontes, 2005, p. 546.

${ }^{560}$ DWORKIN, Ronald. Uma questão de princípio. Título original: A Matter of Principle. Tradução de Luís Carlos Borges. 2. ed. São Paulo: Martins Fontes, 2005, p. 547.
} 
ideia tremendamente abstrata (mas nem um pouco vazia) de que o governo deve tratar as pessoas com igualdade. ${ }^{561}$

Ele visa demonstrar, portanto, como os direitos se ajustam aos diferentes pacotes, e que os direitos devem ser aceitos como trunfos sobre a utilidade.

\subsubsection{O caso Estados Unidos versus Snepp: os apelos ao bem-estar geral atraem a censura}

Dworkin analisa o caso Estados Unidos versus Snepp, onde este assinou um contrato quando se juntou à CIA, prometendo submeter-lhe qualquer coisa que escrevesse posteriormente a seu respeito. A CIA argumenta que esse acordo (realizado com cada agente) é necessário para análise prévia dos materiais que o autor venha a pretender publicar. Caso ela o repute confidencial, e o autor não aceite esse julgamento, ela proporá ação jurídica. Ocorreu que, depois de deixar a agência, Snepp ${ }^{562}$ escreveu e publicou um livro, o "Decent Interval", onde critica rispidamente a conduta do CIA no Vietnã durante o período dos últimos meses da guerra. A CIA valeu-se do contrato para processar Snepp. Este alegou que a Primeira Emenda tornava nula sua aceitação do contrato, já que este consistia numa forma de censura. $\mathrm{O}$ tribunal do distrito não aceitou a reivindicação de Snepp, ordenando que ele, à guisa de reparação, entregasse ao governo todos os lucros obtidos com o livro. O Tribunal de Apelação tampouco recolheu a reivindicação de Snepp (apenas alterando a decisão do tribunal do distrito com relação à severidade da reparação, atenuando-a), que recorreu ao Supremo Tribunal, baseando-se na Primeira Emenda. Por sua vez, o Supremo Tribunal, parecendo estar furioso com a imprensa, recebeu o caso, apenas com a intenção de restabelecer a pena mais severa. ${ }^{563}$ Tal decisão, ao olhar de muitos, mais parecia um "dramático declínio da liberdade de expressão nos EUA”.

Diante desse caso, Dworkin defende a seguinte teoria: o direito destina-se à proteção daquele que fala. Portanto, "qualquer um que sustente essa teoria deve, é claro, demonstrar por que a censura é um dano mais sério que outras formas de regulamentação”. Deverá demonstrar por que alguém que sofre a proibição de falar é mais prejudicado, sofrendo assim um dano mais grave, do que quando é proibido, por exemplo, de dirigir em alta velocidade ou

\footnotetext{
${ }^{561}$ DWORKIN, Ronald. Uma questão de princípio. Título original: A Matter of Principle. Tradução de Luís Carlos Borges. 2. ed. São Paulo: Martins Fontes, 2005, p. 551.

562 SNEPP, Frank. Decent Interval: an Insider's Account of Saigon's Indecent End Told by the CIA's Chief Strategy Analyst in Vietnam. Nova York: Random House, 1977.

${ }^{563}$ DWORKIN, Ronald. Uma questão de princípio. Título original: A Matter of Principle. Tradução de Luís Carlos Borges. 2. ed. São Paulo: Martins Fontes, 2005, p. 568-9.
} 
invadir propriedade alheia. ${ }^{564}$ Teorias preocupadas em proteger aquele que fala sustentam-se em argumentos de princípio a favor da liberdade de expressão. Aquele que fala, desse modo, é dotado de posição especial "como alguém que quer expressar suas convicções em questões de importância política ou social", sendo que tal condição constitui, por si própria, numa autorização, com justiça, a uma "consideração especial”, ainda que isso custe o sofrimento da comunidade como um todo (aqui, o bem-estar da comunidade é desconsiderado, ignorado).

Portanto, quando estivermos diante de uma reivindicação da imprensa por algum privilégio especial, é importante observar se esse privilégio está sustentado por um argumento de política ou de princípio. ${ }^{565}$

Os apelos ao bem-estar geral da comunidade "atraem" a censura (ao invés da publicação) como resposta mais satisfatória ao interesse geral. ${ }^{566}$ Por outro lado, recorrer a direitos individuais proporciona a defesa de um princípio de direito forte o suficiente para fornecer proteção significativa para o caso em concreto.

A leitura dworkineana exige que, diante de uma restrição à livre expressão, questionemos: a restrição deixará alguma pessoa numa condição que se considera negar a igualdade pela Constituição ${ }^{567}$

Se analisarmos nossa Constituição, percebemos que ela inclui, no âmago da igualdade de condições, o direito de falar o que o indivíduo acredita ser importante, bem como o direito de ser fiel à consciência em questões de religião, por exemplo. Assim, a liberdade de expressão não está mais livremente disponível à troca que o direito à crença religiosa. E é por tal motivo que a analogia com os direitos de propriedade é tão pobre:

Se faço uma barganha financeira da qual posteriormente me arrependo, perco dinheiro. Mas minha condição de pessoa que participa da política como igual não foi prejudicada, não pelo menos segundo a definição constitucional do que é essencial para essa condição. Não me vendi como escravo nem fiquei numa situação que a Constituição julga ser parte da escravidão. ${ }^{568}$

Portanto, Dworkin considera que os tribunais devem "encontrar um limite para distinguir renúncias permissíveis de renúncias não permissíveis ao direito constitucional de

\footnotetext{
${ }^{564}$ DWORKIN, Ronald. Uma questão de princípio. Título original: A Matter of Principle. Tradução de Luís Carlos Borges. 2. ed. São Paulo: Martins Fontes, 2005, p. 575.

${ }^{565}$ DWORKIN, Ronald. Uma questão de princípio. Título original: A Matter of Principle. Tradução de Luís Carlos Borges. 2. ed. São Paulo: Martins Fontes, 2005, p. 578.

${ }^{566}$ DWORKIN, Ronald. Uma questão de princípio. Título original: A Matter of Principle. Tradução de Luís Carlos Borges. 2. ed. São Paulo: Martins Fontes, 2005, p. 579.

${ }^{567}$ DWORKIN, Ronald. Uma questão de princípio. Título original: A Matter of Principle. Tradução de Luís Carlos Borges. 2. ed. São Paulo: Martins Fontes, 2005, p. 591-92.

${ }^{568}$ DWORKIN, Ronald. Uma questão de princípio. Título original: A Matter of Principle. Tradução de Luís Carlos Borges. 2. ed. São Paulo: Martins Fontes, 2005, p. 592.
} 
falar". 569

A livre expressão, em todas as suas formas, é, para Dworkin, uma questão de princípio, e argumentos de política convidam à censura, uma vez que "a maioria viola o direito do falante ao censurá-1o" ${ }^{570}$. É, por isso, uma grande injustiça que alguém que quer falar o que pensa seja amordaçado, detido, censurado ou retardado.

\title{
3. LIBERDADE DE EXPRESSÃO NO CENÁRIO BRASILEIRO: O CASO SIEGFRIED ELLWANGER - HC 82.424/RS
}

\subsection{UMA DESCRIÇÃO DO CASO}

Em novembro de 1991, o Ministério Público do Rio Grande do Sul aceitou denúncia contra Siegfried Ellwanger, que foi acusado de incorrer no crime de "incitar e induzir a discriminação racial”, previsto na Lei n. 7.716/89, com a redação da Lei n. 8.081/90, art. 20, caput, que estabelece pena de reclusão de um a três anos para quem "praticar, induzir ou incitar a discriminação ou preconceito de raça, cor, etnia, religião ou procedência nacional”. A denúncia foi assim resumida pelo Promotor de Justiça:

\begin{abstract}
Segundo o incluso inquérito policial, o denunciado Siegfried, na qualidade de escritor e sócio dirigente da Revisão Editora Ltda., situada na Rua Voltaire Pires, $\mathrm{n}^{\circ}$ 300, conj. 02/11, nesta cidade, de forma reiterada e sistemática, edita e distribui, vendendo-as ao público, obras de autores brasileiros e estrangeiros, que abordam e sustentam mensagens anti-semitas, racistas e discriminatórias e com isso procura incitar e induzir a discriminação racial, semeando em seus leitores sentimentos de ódio, desprezo e preconceito contra o povo de origem judaica. ${ }^{571}$
\end{abstract}

Não obstante o teor da denúncia, a juíza substituta Bernadete Coutinho absolveu o paciente, por entender que ele estaria agasalhado pelo direito constitucional à liberdade de expressão. Com isso, os assistentes de acusação recorreram da sentença ao TJRS, obtendo êxito, uma vez que a sentença foi integralmente reformada pela unanimidade dos membros da Câmara Criminal do TJRS. Da referida decisão, Ellwanger impetrou habeas corpus ao STJ, que manteve o acórdão do TJRS, sendo que a única discordância foi do Ministro Edson Vidigal.

Diante da polêmica suscitada pelo caso, o Ministério Público da primeira instância

\footnotetext{
${ }^{569}$ DWORKIN, Ronald. Uma questão de princípio. Título original: A Matter of Principle. Tradução de Luís Carlos Borges. 2. ed. São Paulo: Martins Fontes, 2005, p. 592.

${ }^{570}$ DWORKIN, Ronald. Uma questão de princípio. Título original: A Matter of Principle. Tradução de Luís Carlos Borges. 2. ed. São Paulo: Martins Fontes, 2005, p. 589.

${ }^{571}$ Fl. 18 do processo. SUPREMO TRIBUNAL FEDERAL. Crime de Racismo e Anti-Semitismo: Um Julgamento Histórico do STF (Habeas Corpus n. 82.424/RS). Brasília: Brasília Jurídica, 2004, voto do Ministro Carlos Aires Britto, p. 135.
} 
requereu a absolvição do réu, enquanto os outros órgãos do Ministério Público que atuaram nas outras instâncias persistiam na tipicidade penal da conduta de Ellwanger.

O fundamento da impetração do habeas corpus baseou-se, erroneamente, no fato de que os judeus não configurariam uma raça, e, portanto, Ellwanger não teria cometido crime de racismo.

O julgamento do pedido de Habeas Corpus (HC n. 82.424) de Sigfried Ellwanger, iniciou-se em dezembro de 2002, levando nove meses para ser concluído.

O processo foi distribuído ao Ministro Moreira Alves, que acatou a argumentação do paciente, apontando que o crime de racismo significa apenas preconceito contra a raça negra. O relator concedia, assim, o habeas corpus, declarando extinta a punibilidade do acusado, pois já teria ocorrido a prescrição do crime.

Por sua vez, o Ministro Maurício Corrêa apresentou o primeiro voto divergente, denegando a ordem, ao fazer uso da história bíblica. Corrêa argumentou que a genética eliminou de vez o conceito tradicional de raça, e que a divisão dos seres humanos em raças decorre de um processo político-social originado da intolerância dos homens. Assim sendo, o referido Ministro aponta que a Constituição coíbe atos desse tipo, "mesmo porque as teorias anti-semitas propagadas nos livros editados pelo acusado disseminam ideias que, se executadas, constituirão risco para a pacífica convivência dos judeus no país" ${ }^{572}$

O Ministro Gilmar Mendes também negou a ordem de Habeas Corpus, por entender que "o racismo configura conceito histórico e cultural assente em referências supostamente raciais, aqui incluído o anti-semitismo". Nesse sentido, o Ministro compreendeu que "não se pode atribuir primazia à liberdade de expressão, no contexto de uma sociedade pluralista, em face de valores outros como os da igualdade e da dignidade humana", sendo por essa razão que o texto constitucional erigiu o racismo como crime inafiançável e imprescritível. ${ }^{573}$

Percebemos que o Ministro Gilmar Mendes, em sua análise, recorreu ao uso do princípio da proporcionalidade, que alcança as colisões de bens, valores ou princípios constitucionais, representando um método para a solução de conflitos entre princípios. Assim, o Ministro reconhece uma "tensão dialética que se coloca em face da liberdade de expressão"

\footnotetext{
${ }^{572}$ Voto-vista do Ministro Maurício Corrêa, do Supremo Tribunal Federal, nos autos do HC 82.424/RS, p. $23-45$. In: SUPREMO TRIBUNAL FEDERAL. Crime de Racismo e Anti-Semitismo: Um Julgamento Histórico do STF (Habeas Corpus n. 82.424/RS). Brasília: Brasília Jurídica, 2004.

${ }^{573}$ Ministro Gilmar Mendes, nos autos do HC 82.424/RS, p. 61-66. In: SUPREMO TRIBUNAL FEDERAL. Crime de Racismo e Anti-Semitismo: Um Julgamento Histórico do STF (Habeas Corpus n. 82.424/RS). Brasília: Brasília Jurídica, 2004.
} 
574. Mendes utilizou-se da técnica da ponderação do peso relativo de cada uma das normas em tese aplicáveis e hábeis a fundamentar decisões em sentidos opostos. Nesse sentido, o Ministro citou Robert Alexy:

O postulado da proporcionalidade em sentido estrito pode ser formulado como uma lei de ponderação, cuja fórmula mais simples voltada para os direitos fundamentais diz: quanto mais intensa se revelar a intervenção em um dado direito fundamental, maiores hão de se revelar os fundamentos dessa intervenção. ${ }^{575}$

Ao analisar o acórdão do TJRS, o Ministro Gilmar Mendes conclui ser evidente a adequação da condenação do paciente para que o fim almejado fosse alcançado, a saber, a salvaguarda de uma sociedade pluralista e tolerante. Ademais, ressaltou o Ministro não haver dúvidas sobre a necessidade da medida, tendo em vista a ausência de outro meio menos gravoso e igualmente eficaz. A decisão, portanto, atenderia à proporcionalidade em sentido estrito. Tal perspectiva buscou "aferir a existência de proporção entre o objetivo perseguido, qual seja, a preservação dos valores inerentes a uma sociedade pluralista, da dignidade humana, e o ônus imposto à liberdade de expressão do paciente". 576 Para o Ministro, a liberdade de expressão não alcança a intolerância racial nem o estímulo à violência.

Já o Ministro Marco Aurélio ${ }^{577}$ utilizou-se do mesmo princípio da proporcionalidade, contudo, chegou a uma decisão diametralmente oposta ao do Ministro Gilmar Mendes. Inicialmente, o Ministro Marco Aurélio teceu considerações acerca do sentido da democracia:

Democracia significa assegurar a formação e a boa captação da opinião pública;
significa garantir a soberania popular, para que os rumos do Estado acompanhem
fidedignamente os resultados e as manifestações dessa soberania. Para tanto, o
sistema constitucional brasileiro prevê vários institutos e mecanismos que têm por
finalidade concretizar o princípio democrático, de maneira a torná-lo algo vivo,
presente e eficaz. Na doutrina nacional, costuma-se indicar o sistema eleitoral, o
sufrágio universal, direto, secreto e periódico como uma das mais claras
manifestações jurídicas do princípio democrático. ${ }^{578}$

Para o Ministro, o direito à livre expressão encontra proteção em suas variadas formas,

\footnotetext{
${ }^{574}$ Ministro Gilmar Mendes, nos autos do HC 82.424/RS, p. 69. In: SUPREMO TRIBUNAL FEDERAL. Crime de Racismo e Anti-Semitismo: Um Julgamento Histórico do STF (Habeas Corpus n. 82.424/RS). Brasília: Brasília Jurídica, 2004.

${ }^{575}$ ALEXY, Robert. Palestra proferida na Fundação Casa de Rui Barbosa. Rio de Janeiro, em 10/12/98, apud Ministro Gilmar Mendes, nos autos do HC 82.424/RS, p. 71. In: SUPREMO TRIBUNAL FEDERAL. Crime de Racismo e Anti-Semitismo: Um Julgamento Histórico do STF (Habeas Corpus n. 82.424/RS). Brasília: Brasília Jurídica, 2004.

${ }^{576}$ OMMATI. José Emílio Medauar. Liberdade de Expressão e Discurso de Ódio na Constituição de 1988. 2.ed. Rio de Janeiro: Lumen Juris, 2014, p. 30.

${ }^{577}$ Ministro Marco Aurélio, nos autos do HC 82.424/RS, p. 162-170. In: SUPREMO TRIBUNAL FEDERAL. Crime de Racismo e Anti-Semitismo: Um Julgamento Histórico do STF (Habeas Corpus n. 82.424/RS). Brasília: Brasília Jurídica, 2004.

${ }^{578}$ Ministro Marco Aurélio, nos autos do HC 82.424/RS, p. 171. In: SUPREMO TRIBUNAL FEDERAL. Crime de Racismo e Anti-Semitismo: Um Julgamento Histórico do STF (Habeas Corpus n. 82.424/RS). Brasília:

Brasília Jurídica, 2004.
} 
e é por meio desse direito que alcançamos a participação democrática, garantindo-se que as mais diferentes e inusitadas opiniões sejam externadas de forma aberta, sem a preocupação de estarem contrariando o Estado ou mesmo a opinião majoritária. Tal perspectiva é, para o Ministro, pressuposto para uma sociedade livre e plural, com diversas correntes de ideologias, pensamentos e opiniões políticas. Em seu embasamento, o Ministro recorreu a autores de grande relevância em cenário mundial, tais como Ernst-Wolfgang Böckenförde, Hans Kelsen, além de importantes decisões da Suprema Corte Americana.

Não obstante tenha reconhecido que o livro de Ellwanger contenha uma clara ideia preconceituosa, o referido Ministro asseverou que não se pode proibir essa ideia:

\begin{abstract}
A questão de fundo neste Habeas Corpus diz respeito à possibilidade de publicação de livro cujo conteúdo revele ideias preconceituosas e antissemitas. Em outras palavras, a pergunta a ser feita é a seguinte: o paciente, por meio do livro, instigou ou incitou a prática do racismo? Existem dados concretos que demonstrem, com segurança, esse alcance? A resposta, para mim, é desenganadamente negativa. (...)

Há de se proclamar a autonomia do pensamento individual como uma forma de proteção à tirania imposta pela necessidade de adotar-se sempre o pensamento politicamente correto. As pessoas simplesmente não são obrigadas a pensar da mesma maneira. ${ }^{579}$
\end{abstract}

Além disso, ressaltou o Ministro Marco Aurélio, o Estado se torna mais democrático quando não expõe esse tipo de trabalho a uma censura oficial, mas, em vez disso, deixa à sociedade a incumbência de realizar tal censura. Em sua opinião, somente estaria configurado o crime de racismo se Ellwanger, em vez de publicar um livro onde suas ideias acerca da relação entre os judeus e os alemães na Segunda Guerra Mundial são expostas, como na espécie, "distribuísse panfletos nas ruas de Porto Alegre com dizeres do tipo 'morte aos judeus', 'vamos expulsar estes judeus do País', 'peguem as armas e vamos exterminá-los'. Mas nada disso aconteceu no caso em julgamento". 580

Portanto, segundo Marco Aurélio, Ellwanger restringiu-se a escrever e a difundir a versão da história vista com os próprios olhos.

Após tais constatações, o Ministro passou a analisar a colisão entre os direitos fundamentais, recorrendo ao princípio da proporcionalidade, e, com isso, chegou à conclusão de que a condenação do paciente resultaria excessiva, desproporcional. Posteriormente, ele concluiu que não teria havido crime de racismo, sendo que somente poderia incidir a prática

\footnotetext{
${ }^{579}$ Ministro Marco Aurélio, nos autos do HC 82.424/RS, p. 177 e ss. In: SUPREMO TRIBUNAL FEDERAL. Crime de Racismo e Anti-Semitismo: Um Julgamento Histórico do STF (Habeas Corpus n. 82.424/RS). Brasília: Brasília Jurídica, 2004.

${ }^{580}$ Ministro Marco Aurélio, nos autos do HC 82.424/RS, p. 177 e ss. In: SUPREMO TRIBUNAL FEDERAL. Crime de Racismo e Anti-Semitismo: Um Julgamento Histórico do STF (Habeas Corpus n. 82.424/RS). Brasília: Brasília Jurídica, 2004.
} 
de racismo contra o negro, "sob pena de se criar um tipo constitucional penal aberto imprescritível", 581

O Ministro Celso de Mello ${ }^{582}$, por sua vez, acompanhou a dissidência, destacando que "só existe uma raça: a espécie humana". E acrescentou: "Aquele que ofende a dignidade de qualquer ser humano, especialmente quando movido por razões de cunho racista, ofende a dignidade de todos e de cada um”. Achou correta a condenação de Ellwanger, negando-lhe o Habeas Corpus. Vale mencionar um trecho de seu voto:

Encerro o meu voto, Senhor Presidente. E, ao fazê-lo, devo enfatizar que este julgamento, como aqui já foi referido, mostra-se impregnado de alto e transcendente valor emblemático, pois nele está em debate, uma vez mais, o permanente conflito entre civilização e barbárie, cabendo, ao Supremo Tribunal Federal, fazer prevalecer, em toda a sua grandeza, a essencial e inconspurcável dignidade das pessoas, em solene reconhecimento de que, acima da estupidez humana, acima da insensibilidade moral, acima das distorções ideológicas, acima das pulsões irracionais e acima da degradação torpe dos valores que estruturam a ordem democrática, deverão sempre preponderar os princípios que exaltam e reafirmam a superioridade ética dos direitos humanos, cuja integridade, uma vez mais, será preservada, aqui e agora, em prol de todos os cidadãos e em respeito aos milhões de seres humanos que a crueldade inominável do regime nazista, em momento sombrio e declinante da História, destruiu e martirizou em um holocausto que jamais deverá ser apagado da memória de todos nós, permanecendo, ao contrário, como uma grave advertência, para as presentes e futuras gerações, de que o MAL jamais deverá triunfar outra vez. ${ }^{\mathbf{5 8 3}}$ (grifos no original)

O Ministro adere-se à teoria externa dos direitos fundamentais, quando assevera que

(...) os postulados da igualdade e da dignidade pessoal dos seres humanos constituem limitações externas à liberdade de expressão, que não pode, e não deve, ser exercida com o propósito subalterno de veicular práticas criminosas, tendentes a fomentar e a estimular situações de intolerância e de ódio público. $^{584}$ (grifos no original)

Seguindo a maioria e votando denegação do Habeas Corpus, o Ministro Cezar Peluso apontou que "a discriminação é uma perversão moral, que põe em risco os fundamentos de uma sociedade livre". 585

\footnotetext{
${ }^{581}$ Ministro Marco Aurélio, nos autos do HC 82.424/RS, p. 185 e ss. In: SUPREMO TRIBUNAL FEDERAL. Crime de Racismo e Anti-Semitismo: Um Julgamento Histórico do STF (Habeas Corpus n. 82.424/RS). Brasília: Brasília Jurídica, 2004.

${ }_{582}$ Ministro Celso de Mello, nos autos do HC 82.424/RS, p. 203-204. In: SUPREMO TRIBUNAL FEDERAL. Crime de Racismo e Anti-Semitismo: Um Julgamento Histórico do STF (Habeas Corpus n. 82.424/RS). Brasília: Brasília Jurídica, 2004.

${ }_{583}$ Ministro Celso de Mello, nos autos do HC 82.424/RS, p. 203-204. In: SUPREMO TRIBUNAL FEDERAL. Crime de Racismo e Anti-Semitismo: Um Julgamento Histórico do STF (Habeas Corpus n. 82.424/RS). Brasília: Brasília Jurídica, 2004.

${ }^{584}$ Antecipação dos votos do Ministro Celso de Mello, nos autos do HC 82.424/RS, p. 60. In: SUPREMO TRIBUNAL FEDERAL. Crime de Racismo e Anti-Semitismo: Um Julgamento Histórico do STF (Habeas Corpus n. 82.424/RS). Brasília: Brasília Jurídica, 2004.

${ }^{585}$ SUPREMO TRIBUNAL FEDERAL. STF nega Habeas Corpus a editor de livros condenado por racismo contra judeus. Disponível em: < http://www.stf.jus.br/portal/cms/verNoticiaDetalhe.asp?idConteudo=61291\&caixaBusca=N $>$. Acesso em 15 fev. 2015.
} 
O Ministro Carlos Ayres Britto elencou elementos em defesa da democracia que permite a convivência de opostos, reconhecendo que nosso estágio constitucional é dotado de conflitos, de princípios em tensão:

\begin{abstract}
Esse fenômeno da inter-referibilidade por oposição é de maior ocorrência ---- força é dizê-lo ---- no curso das relações que os particulares travam entre si e com o propósito de exercitar direitos e garantias individuais. Que são direitos e garantias imediatamente referidos ao princípio constitucional da dignidade da pessoa humana e defluentes de uma sociedade culturalmente pluralista; ou seja, de uma sociedade que se compõe de grupos humanos culturalmente díspares, formados por seres dotados de estrutura biopsíquica também personalíssima. Vale dizer, pessoas de mundividência e gosto pelas coisas verdadeiramente únicos. Por isso mesmo, pessoas que se fazem detentoras de uma jurídica autonomia de vontade para materializar as suas insimilares convicções políticas e filosóficas, de parelha com suas também insimilares preferências estéticas, profissionais, sexuais, religiosas, culinárias, etc., pois somente assim é que o ser humano se realiza enquanto ser humano mesmo ("ninguém é igual a ninguém", "cada cabeça uma sentença" e "gosto não se discute" são ditos populares que muito bem exprimem a incrível capacidade que tem a natureza de jamais se repetir). Assumindo o Direito Positivo, de conseguinte, o inevitável risco de ver uma dada autonomia de vontade a se antagonizar com outra, por abuso de uma delas. ${ }^{586}$
\end{abstract}

Nesse sentido, um Direito que permite a convivência entre os contrários é agraciado por "um dos mais expressivos conteúdos da Democracia". Embora reconheça,de antemão, que "a abstrata legitimação do uso de uma vontade individual pode resvalar para a danosa prática da abusividade", o Ministro prefere voltar seus olhos ao convencimento "da maior valiosidade da premissa democrática de que não é pelo receio do abuso que se vai proibir o uso daqueles direitos e garantias em que mais resplende o valor da Liberdade". 587

Não obstante o Ministro tenha entendido por conceder o habeas corpus, de ofício, pela atipicidade da própria conduta do paciente, “à época dos fatos noticiados na denúncia. E como se trata de impedir, aqui, a consumação de nulidade absoluta (retroatividade da lei penal para prejudicar o réu)", ele reuniu importantes argumentos em defesa da liberdade de expressão. ${ }^{588}$ O Ministro procurou observar, com cuidado, a linha divisória entre o uso e o abuso da liberdade de expressão:

\footnotetext{
${ }^{586}$ SUPREMO TRIBUNAL FEDERAL. STF nega Habeas Corpus a editor de livros condenado por racismo contra judeus. Disponível em: <

http://www.stf.jus.br/portal/cms/verNoticiaDetalhe.asp?idConteudo=61291\&caixaBusca=N>. Acesso em 15 fev. 2015.

${ }^{587}$ SUPREMO TRIBUNAL FEDERAL. STF nega Habeas Corpus a editor de livros condenado por racismo contra judeus. Disponível em: <

http://www.stf.jus.br/portal/cms/verNoticiaDetalhe.asp?idConteudo=61291\&caixaBusca=N>. Acesso em 15 fev. 2015.

${ }^{588}$ SUPREMO TRIBUNAL FEDERAL. STF nega Habeas Corpus a editor de livros condenado por racismo contra judeus. Disponível em: <

http://www.stf.jus.br/portal/cms/verNoticiaDetalhe.asp?idConteudo=61291\&caixaBusca=N>. Acesso em 15 fev. 2015. O Ministro Carlos Ayres Britto compartilhou em seu voto o trocadilho ao qual recorrera, em poema antigo: "a liberdade de expressão é a maior expressão da liberdade".
} 
43. Agravo e abuso passam a ser ventilados, portanto, já no plano da reação de outrem; sendo que o agravo suscita o exercício de um direito de resposta que nem depende de processo de apuração de transbordamento da originária autonomia de vontade. $\mathrm{O}$ abuso, no entanto, pressupõe a constatação processual do transbordamento daquela primitiva autonomia de vontade. Um transbordamento que só é transbordamento por violar uma outra e alheia autonomia de vontade, também juridicamente prezada. Mas a premissa da Constituição é uma só: não é pela possibilidade de agravo a terceiros, ou de uso invasor da liberdade alheia, que se vai coibir a primitiva liberdade de expressão (que se define, assim, como liberdade absoluta, nesse plano da incontrolabilidade da sua apriorística manifestação). Sendo que esse fraseado em si - "liberdade de expressão"- alcança as duas tipologias de liberdade: a liberdade de manifestação do pensamento e a liberdade de ação no quadripartite domínio intelectual, científico, artístico e de comunicação.

(...)

44. Pontue-se bem a diferença: do ângulo da autonomia de vontade de quem fala, escreve, gesticula, ou ainda de quem produz uma obra de natureza artística, intelectual, científica, ou de comunicação, o que se tutela de forma até absoluta é o direito mesmo de fazer algo ou passar para outrem uma mensagem, um recado, uma obra. Transformar em ação ou coisa objetiva algo até então subjetivo. O que se traduz no exercício do direito de não sofrer impedimento ou censura prévia nesse ato mesmo de agir ou de dirigir-se a terceiros. E uma vez operado esse transpasse de um momento psíquico de vida humana para um momento fático de vida social, realizada fica essa espécie de autonomia de vontade. Se se prefere, é no instante mesmo de materialização da autonomia de vontade que o direito subjetivo se realiza e a Constituição resta plenamente respeitada. Mas ele, direito subjetivo, tem no próprio instante de sua realização o exaurimento do seu conteúdo; quero dizer, não incorpora a si a força de bloquear posturas reativas de terceiros eventualmente prejudicados nas respectivas autonomias de vontade.

(...)

45. Veja-se então o outro ângulo, que é o prisma de quem se sente vítima de agravo ou de abuso no exercício da primeira modalidade de autonomia de vontade. Agora, o que se protege é: primeiro, o direito de resposta; segundo, o direito de desencadear um processo de apuração de abusividade, com o fito de responsabilização tanto civil quanto penal (se for o caso) do agente abusivo; pois é óbvio que a tutela penal de certos valores ---- como a honra pessoal e a não-submissão a práticas racistas, por hipótese ----, implica a possibilidade de acesso a uma jurisdição especificamente criminal. Para além, portanto, daquele singelo direito de resposta e até mesmo da prefalada reparação civil. ${ }^{589}$ [sem grifo no original]

Por fim, o Supremo Tribunal Federal manteve a condenação do editor Siegfried Ellwanger a ele imposta pelo Tribunal de Justiça do Rio Grande do Sul por crime de racismo. O julgamento do Habeas Corpus (HC 82424) ajuizado pela defesa de Ellwanger foi concluído em 17/9/2003. Por maioria de sete a três, o Plenário negou o recurso, vencidos os ministros Moreira Alves, Marco Aurélio e Carlos Ayres Britto.

\subsection{O CAMINHO PERQUIRIDO PELO STF RUMO À DECISÃO: O APELO AO MÉTODO}

${ }^{589}$ SUPREMO TRIBUNAL FEDERAL. STF nega Habeas Corpus a editor de livros condenado por racismo contra judeus. Disponível em: < http://www.stf.jus.br/portal/cms/verNoticiaDetalhe.asp?idConteudo=61291\&caixaBusca=N $>$. Acesso em 15 fev. 2015. 
Elencamos, acima, trechos dos votos que compuseram a decisão do STF no caso Ellwanger, bem como uma sucinta descrição do caso. Em análise acerca de como decidiram os ministros diante do caso, é possível tecer algumas considerações.

De um lado, tínhamos Siegfried Ellwanger, um editor e escritor gaúcho, o paciente do habeas corpus, que publicara obras de sua autoria bem como de outros autores, buscando um suposto revisionismo histórico em torno do Holocausto dos judeus. De outro lado, tínhamos os judeus de todo o país, que se sentiram diminuídos com o que Elwanger escrevera - que o Holocausto não passara de um golpe judaico voltado a ganhar vantagens políticas, econômicas e sociais.

Não obstante se tenha colocado, inicial e aparentemente, enquanto questão central, o questionamento de se os judeus configurariam uma raça ou não, o que realmente esteve em jogo durante todo o processo "foi exatamente qual a configuração do direito de liberdade de expressão no Texto Constitucional de 1988". ${ }^{590}$ Portanto, o que foi objeto de análise pelos aplicadores do direito foi a localização da liberdade de expressão, sua abrangência, seus limites, e o que ela significa em nosso cenário.

É nítido o uso da ponderação de valores como método aclamado pela doutrina e jurisprudência brasileiras como forma de solução de conflitos entre direitos. No caso Ellwanger, isso não foi diferente. O Direito, ao contrário do que propõem os sectários da ponderação, não é gradual, mas um código binário. A dúvida acerca de qual lado está correto não significa a inexistência de uma resposta correta. Contudo, essa resposta correta não é algo que nos é dado mediante o uso de um método, mas construído, e reconstruído, pelos argumentos, em cada caso concreto, que é dotado de unicidade e de irrepetibilidade, se se propõe a respeitar os direitos enquanto trunfos.

Os princípios constitucionais não são valores gradualmente aplicáveis. A leitura do direito enquanto integridade nos exige a compreensão de que a sociedade é regida por uma comunidade de princípios, e que existe uma tensão constitutiva entre esses princípios, de modo que, ao optarmos por um deles, nada se perde.

Ao recorrerem à técnica da ponderação de valores, os ministros do STF “continuaram a tratar a o Direito e a Constituição como uma ordem concreta de valores, passíveis de ponderação em caso de conflito (...), gerando uma perda de racionalidade da decisão". 591 Ronald Dworkin mostra-nos que o problema está na compreensão de que os valores entrem

${ }^{590}$ OMMATI. José Emílio Medauar. Liberdade de Expressão e Discurso de Ódio na Constituição de 1988. 2.ed. Rio de Janeiro: Lumen Juris, 2014, p. 4-5.

${ }_{591}$ OMMATI. José Emílio Medauar. Liberdade de Expressão e Discurso de Ódio na Constituição de 1988. 2.ed. Rio de Janeiro: Lumen Juris, 2014, p. 6. 
em conflito. A compreensão do Direito principiológico como um todo enquanto valor não é um problema. O valor é uma coisa muito importante. O empréstimo da citação do dramaturgo grego Arquíloco, segundo o qual "a raposa sabe muitas coisas, e o ouriço sabe uma só, mas o que o ouriço sabe é muito importante" é utilizado em "Justice for Hedgehogs", momento no qual Dworkin sustenta a tese principal da unidade do valor. ${ }^{592}$

Nesse sentido, a interpretação dos juízes deve orientar-se rumo à única resposta correta, coerente com os valores morais que melhor justifiquem a trajetória políticoconstitucional de um Estado, de modo que, se assim forem interpretadas as normas constitucionais, o conflito torna-se constitutivo, produtivo. A Justiça constitucional, para Dworkin, é uma Justiça de ouriço.

É nesse sentido que Dworkin se opõe à ideia de que liberdade e igualdade entrem em colisão, afirmando que elas não são virtudes independentes, "mas aspectos do mesmo ideal de associação política". 593

Percebemos que o uso do princípio da proporcionalidade impossibilita o alcance da única decisão correta, uma vez que demanda a perseguição a um método pré-fixado, que em nada garante a verdade, e que não matiza os valores de quem os aplica. Percebemos que, amparando-se do mesmo método, os Ministros Marco Aurélio e Gilmar Mendes chegaram a decisões diametralmente opostas. Como solução a essa deficiência, recorremos, mais uma vez, a Dworkin, tendo em vista que, se o Direito é valor, isso não implica que devo aplicá-lo na maior medida possível em seu grau ótimo, como pretende Alexy, "mas sim que ou o valor vale ou não vale". 594

Se perquirirmos o caminho proposto por Alexy, deparar-nos-emos diante da tensão conflituosa entre igualdade e liberdade, de modo que os princípios que decorrem desses dois postulados passarão sempre por uma graduação que dificilmente realizará o ideal exigido pela justiça. A crença no método heurístico, insistimos, não é garantia de defesa, não é garantia da verdade. Por outro lado, a única resposta correta é alcançada mediante o esforço interpretativo do juiz, à guisa da Justiça de ouriços.

Pois bem, vale agora analisar o espaço que ocupa a liberdade de expressão na modalidade do hate speech para que os direitos sejam levados a sério.

\footnotetext{
${ }^{592}$ Cf. DWORKIN, Ronald. A raposa e o porco-espinho: justiça e valor. Tradução de Marcelo Brandão Cipolla. São Paulo: Editora WMF Martins Fontes, 2014.

${ }^{593}$ Cf. DWORKIN, Ronald. A raposa e o porco-espinho: justiça e valor. Tradução de Marcelo Brandão Cipolla. São Paulo: Editora WMF Martins Fontes, 2014.

${ }^{594}$ OMMATI. José Emílio Medauar. Liberdade de Expressão e Discurso de Ódio na Constituição de 1988. 2.ed. Rio de Janeiro: Lumen Juris, 2014, p. 6.
} 
3.3 A DECISÃO DO STF ATENDEU A EXIGÊNCIA DE SE LEVAR OS DIREITOS A SÉRIO? É POSSÍVEL A RECONCILIAÇÃO ENTRE LIBERDADE E IGUALDADE NO DISCURSO DO ÓDIO? LEIS ANTIDISCRIMINATÓRIAS CONVIVEM COM A LIBERDADE DE EXPRESSÃO EM UM CENÁRIO DE INCLUSÃO DE MINORIAS?

Ao enfrentarem o incômodo e desconcertante tema do discurso do ódio (hate speech), as pessoas podem discordar ou não saber ao certo se a censura pode coibir uma liberdade de expressão na modalidade do discurso do ódio. O certo é que nenhum método é capaz de nos entregar uma resposta ao caso, que demanda um esforço interpretativo coerente.

\subsubsection{Liberdade de expressão restringida: a impossibilidade do discurso do ódio no cenário jurídico brasileiro}

Iniciaremos nossa colocação a partir da leitura de que a decisão do Supremo foi acertada, na medida em que cumpriu com o compromisso histórico exigido pelo constituinte de 1988, e, portanto, atendeu à demanda da história jurídica e institucional da sociedade brasileira.

Para os sectários dessa ideia, a história jurídico-institucional brasileira não abre espaço para o discurso do ódio, por se tratar de um discurso racista e discriminatório. Estes acreditam ser impossível a convivência entre o discurso do ódio e as leis antidiscriminatórias. Ademais, a permissão do discurso do ódio violaria o compromisso histórico-democrático, por dificultar a inclusão das minorias.

Nesse cenário, o discurso do ódio ultrapassaria as barreiras da liberdade de expressão, por se tratar de um discurso violador de direitos. Entender-se-ia, portanto, que a Constituição, de 1988, ao criminalizar a prática de racismo, juntamente à Lei n. 7.716/89, com redação dada pela Lei n. 8.081/90, proibiram o discurso do ódio.

José E. Medauar Ommati ${ }^{595}$ aponta "uma contradição interna insanável” na perspectiva de Dworkin acerca da permissibilidade de discursos do ódio, mesmo os mais perversos e racistas, que não podem ser proibidos, em nome da igual consideração e respeito. Para Ommati, uma Constituição que garante os princípios da igualdade e da liberdade em um ordenamento democrático somente poderá ser entendida corretamente da seguinte maneira:

(...) como um projeto inacabado, passível de ser reapropriado pelas gerações futuras e, sendo um aprendizado histórico, a nossa Constituição é fruto e herdeira, não apenas do Holocausto e da imensa perversidade cometida contra os judeus, mas

\footnotetext{
${ }^{595}$ OMMATI. José Emílio Medauar. Liberdade de Expressão e Discurso de Ódio na Constituição de 1988. 2.ed. Rio de Janeiro: Lumen Juris, 2014, p. 100.
} 
também das perversidades que praticamos historicamente contra os negros, mulheres, homossexuais, e outras categorias de pessoas. ${ }^{596}$

Aqui surge a tipificação do crime de racismo, verdadeiro escudo a ser utilizado na defesa contra essas perversidades, sendo plausivelmente dotado de imprescritibilidade e de inafiançabilidade. A previsão constitucional inserida no art. $5^{\circ}$, incisos XLI e XLII é, portanto, fruto da sinalização de uma tentativa da sociedade brasileira de repudiar o racismo e suas formas discriminatórias. Lembremo-nos que, ao contrário da interpretação restrita dos Ministros Moreira Alves e Marco Aurélio, a história institucional brasileira mostra que não somos apenas intolerantes com os negros, mas também com as mulheres, com os judeus, com os homossexuais, dentre outras minorias, todas merecedoras de igual proteção constitucional e legal.

Autores como Stephen Holmes e Cass Sustein ${ }^{597}$, bem como Owen Fiss ${ }^{598}$ e, ainda, Jeremy Waldron ${ }^{599}$ sustentam a favor da proibição de alguns discursos, na medida em que há discursos que calam outras pessoas. Fiss questiona, ainda, se o hate speech estaria albergado pela liberdade de expressão.

Em “The Harm in Hate Speech”, Jeremy Waldron argumenta que a liberdade de expressão nos Estados Unidos é tão absoluta, tanto na lei como na opinião pública, que lhes falta regulação significativa contra o discurso do ódio, dirigido a humilhar ou difamar minorias. Baseando-se em investigações legais e históricas, o tratado de Jeremy Waldron consiste, principalmente, em uma defesa filosófica da regulação do hate speech. Ele aponta esse tipo de discurso como um problema ambiental que polui a atmosfera da segurança e da dignidade que a sociedade deve conferir a seus membros:

\begin{abstract}
In a well-ordered society (...) everyone can enjoy a certain assurance as they go about their business. They know that when they leave home in the morning, they can count on not being discriminated against or humiliated or terrorized...they can face social interactions without the elemental risks that such interaction would involve if one could not count on others to act justly. ${ }^{600}$
\end{abstract}

Recorrendo ainda aos argumentos em prol do bem-estar geral, Waldron considera que o hate speech configura, por si, uma gravidade, um mal, e acrescenta: "the tiny impacts of

\footnotetext{
${ }^{596}$ OMMATI. José Emílio Medauar. Liberdade de Expressão e Discurso de Ódio na Constituição de 1988. 2.ed. Rio de Janeiro: Lumen Juris, 2014, p. 9.

${ }^{597}$ Cf. HOLMES, Stephen e SUSTEIN, Cass. El Costo de los Derechos: Por qué la libertad depende de los impuestos. Buenos Aires: Siglo XXI Editores, 2011.

${ }^{598}$ Cf. FISS, Owen. A Ironia da Liberdade de Expressão: Estado, Regulação e Diversidade na Esfera Pública. Rio de Janeiro: Editora Renovar, 2005.

${ }^{599}$ Cf. WALDRON, Jeremy. The Harm in Hate Speech. Cambridge: Harvard University Press, 2012.

${ }^{600}$ WALDRON, Jeremy. The Harm in Hate Speech. Cambridge: Harvard University Press, 2012 apud

TOWNSEND, Daniel. Where to Draw the Line on Hate Speech? In: The American Prospect, June, 2012.

Disponível em: < http://prospect.org/article/where-draw-line-hate-speech>. Acesso em 15 jan. 2016.
} 
millions of actions - each apparently inconsiderable in itself-can produce a large-scale toxic effect." 601

A Lei n. 7.716/89 criminaliza os atos de racismo utilizando-se de verbos referentes à exclusão, tais como impedir, obstar, recusar, negar, referindo-se ao acesso a ambientes públicos e privados, a estabelecimentos, a atendimentos etc. Posteriormente, adveio o art. 20, que incluiu aos quadros do racismo a prática, a indução, ou a incitação da discriminação ou preconceito de raça, cor, etnia, religião ou procedência nacional.

Haveria, então, como compatibilizar esses discursos com a proibição do racismo no cenário brasileiro? A nosso ver, a questão gira em torno do enquadramento do discurso do ódio ao tipo penal incriminador. O discurso do ódio mergulha nos verbos (praticar, induzir e incitar) elencados pelo art. 20 da Lei de Discriminação Racial brasileira?

Praticar a discriminação ou o preconceito significa levá-lo a efeito, realizá-lo. A prática do racismo configura, aparentemente, um caso cristalino, como, por exemplo, a recusa de atendimento a negros em uma determinada loja comercial. O problema é que a discriminação segregacionista, nesses casos, acontece, de forma sutil e disfarçada, "transnominada" de termos como, por exemplo, a exigência de "boa aparência" para ocupação de empregos, o "uso de elevadores de serviço" para funcionários, "mérito escolar", por motivação técnica ou mesmo cultural para a ocupação de determinado cargo. Pois bem, sem a pretensão de adentrar nas formas disfarçadas de discriminação, prossigamos.

Induzir a discriminação ou o preconceito seria persuadir, convencer as pessoas àquele preconceito ou discriminação. Enquanto incitar seria estimular, incentivar, instigar a discriminação ou o preconceito. É na indução e na incitação que se enquadraria o discurso do ódio no contexto brasileiro, que preferiu não correr o risco de pagar o preço do racismo.

A partir do resultado a que chegou o STF, percebemos ser incompatível o hate speech com nossa lei antidiscriminatória. Portanto, Medauar Ommati encontra, em Dworkin, o que ele chama de incongruência insanável, uma vez que "o autor americano, nesse ponto, não conseguiu compreender corretamente a própria história institucional de seu país e as exigências de integridade". ${ }^{602}$ Assim, Medauar Ommati defende que a ideia de integridade depende não apenas da análise da teoria em si, mas, principalmente, da história jurídica e

\footnotetext{
${ }^{601}$ WALDRON, Jeremy. The Harm in Hate Speech. Cambridge: Harvard University Press, 2012 apud TOWNSEND, Daniel. Where to Draw the Line on Hate Speech? In: The American Prospect, June, 2012. Disponível em: < http://prospect.org/article/where-draw-line-hate-speech>. Acesso em 15 jan. 2016.

${ }^{602}$ OMMATI. José Emílio Medauar. Liberdade de Expressão e Discurso de Ódio na Constituição de 1988. 2.ed. Rio de Janeiro: Lumen Juris, 2014, p. 97.
} 
institucional de cada comunidade de princípios. ${ }^{603}$ No Brasil, não se poderia afirmar em qualquer hipótese que a liberdade de expressão seja entendida como a possibilidade de se proferir o discurso do ódio que se configure como racista e discriminatório.

\subsubsection{Uma abertura à possibilidade do discurso do ódio em nosso contexto}

Acabamos de afirmar a visão majoritária de nossa Suprema Corte, segundo a qual, no Brasil, não se poderia afirmar, em qualquer hipótese, que a liberdade de expressão seja entendida como a possibilidade de se proferir o discurso do ódio que se configure como racista e discriminatório.

Contudo, ocorre que, à luz da nossa lei de crimes raciais, praticamente todo discurso do ódio desembocará no racismo, porque compreendemos, majoritariamente, que esse discurso promove, instiga e incita a violência e a discriminação racial, uma vez que traçamos a tênue linha divisória antes do marco do respeito à independência ética, postulado decorrente da igual consideração e respeito.

O que gostaríamos, neste estudo, é, à luz da perspectiva dworkineana, convidar o leitor à busca de uma abertura capaz de superar o medo do risco especulativo que o discurso do ódio pode representar.

Que a censura prévia ao discurso do ódio seja proibida, não se discute. Assim, os discursos do ódio, a priori, não devem ser proibidos, em respeito à exigência do princípio democrático. Isso porque "a priori, ninguém é capaz de realizar discurso de ódio ou discurso racista. Para que um discurso possa ser visto como racista ou discriminador, ele deve passar pelo espaço público". ${ }^{604}$ Posteriormente, se ficar comprovado, pela discussão pública, que esse discurso fere as garantias legais e constitucionais brasileiras, será proibido, e o proferidor, responsabilizado. O que se polemiza, portanto, é a permissibilidade de se conferir espaço a um discurso do ódio, ainda que, depois de proferido, acarrete em um mal-estar comunitário.

Já discorremos, na Parte I do presente estudo, acerca da identidade constitucional. Vale lembrar que sua formação encontra consonância com o pressuposto do postulado da igual consideração e respeito. Pois bem, é inegável que a inclusão dos indivíduos

\footnotetext{
${ }^{603}$ OMMATI. José Emílio Medauar. Liberdade de Expressão e Discurso de Ódio na Constituição de 1988. 2.ed. Rio de Janeiro: Lumen Juris, 2014, p. 99.

${ }^{604}$ OMMATI. José Emílio Medauar. Liberdade de Expressão e Discurso de Ódio na Constituição de 1988. 2.ed. Rio de Janeiro: Lumen Juris, 2014, p. 100.
} 
pressuponha, nas palavras de Habermas, o "igual acesso a relações e tradições sociais constitutivas-de-identidade", 605

A identidade constitucional contemporânea é conformada, dentre outras coisas, pelo respeito aos direitos fundamentais de igualdade e de liberdade de expressão. Não obstante , "se desvinculados de todos os laços e identidades nacionais ou culturais relevantes, esses direitos constitucionais fundamentais permaneceriam por demais amorfos para permitir aplicações cogentes”. Sem dúvida, as decisões constitucionais clamam por referências à identidade nacional e/ou cultural, como é o caso de se decidir se a liberdade de expressão do pensamento envolve ou não o direito a proferir discursos extremistas. ${ }^{606}$

Já demonstramos que o giro linguístico decorrente do atual paradigma democrático pressupõe que o Estado trate a todos com igual consideração e respeito pela responsabilidade pessoal (equal concern and respect for responsability), o que desemboca no reinado do princípio da igualdade, do qual decorrem a liberdade (liberty) e a independência ética (ethical independence).

Assim, liberdade e igualdade não entram em conflito, mas se complementam sempre que os direitos individuais a diferentes liberdades serão reconhecidos somente quando se puder mostrar que o direito fundamental a ser tratado como igual (treatment as an equal) exige tais direitos. Se uma determinada liberdade for exigida pelo princípio da igual consideração e respeito, então ela merece reconhecimento enquanto um direito forte, um verdadeiro trunfo contra o Estado.

A partir da leitura dworkineana, Samantha Ribeiro Meyer-Pflug ${ }^{607}$ afirma que a liberdade de expressão encontra justificativa tanto em uma perspectiva independente, pois a liberdade de expressão é um direito-trunfo-fundamental como em uma perspectiva instrumental, pois a liberdade de expressão é um direito na medida em que promove a democracia.

Defendemos a concepção de direitos fundamentais enquanto trunfos inerentes a todo e qualquer cidadão, de modo que o Estado comete um erro ao restringir esses trunfos com base no interesse geral. É nesse sentido que já apontamos nossas críticas aos argumentos

\footnotetext{
${ }^{605}$ HABERMAS, Jürgen. Notas sobre a tríade de Denninger: diversidade, segurança e solidariedade. Tradução livre, p. 6.

${ }^{606}$ ROSENFELD, Michel. A identidade do sujeito constitucional. Texto original: The identity of the constitutional subject. In: Cardoso Law Review: A Mentalidade Pós-Moderna e o Direito, Nova Iorque: Yeshiva University Press, p. 1049-1109, Janeiro de 1995. Copyright: Yeshiva University e Michel Rosenfeld, p.3.

${ }^{607}$ Cf. MEYER-PFLUG, Samantha Ribeiro. Liberdade de expressão e discurso do ódio. São Paulo: Editora Revista dos Tribunais, 2009
} 
utilitaristas, na medida em que eles impingem um determinado modo de viver, o que desrespeita o postulado da independência ética.

Neste momento, devemos lembrar que a democracia pressupõe mais que o consenso: ela clama pela abertura ao dissenso. Alertemos para o risco de quando uma maioria tenta impor às pessoas o que ela entende por certo ou por errado. A liberdade de expressão é um direito particularmente necessário a um justo e adequado sistema democrático de governo. $\mathrm{E}$ ela encontra refúgio no respeito à independência ética, tendo em vista que uma maioria não tem o direito de me impor suas convicções externas, ou seja, suas preferências sobre o bem viver.

Entendemos que a inclusão de minorias, pressuposto crucial para a formação de uma identidade constitucional, não resta prejudicada com a proteção do discurso do ódio. Pois o direito-trunfo à voz igual de cada cidadão não deve ser seletivo. Ora, a voz é igual, independentemente de se configurar em uma voz odiosa, ou bondosa. Portanto, a liberdade de expressão é pressuposto da abertura democrática e da igual consideração e respeito que o Estado deve aos seus concidadãos. A censura ao discurso do ódio configura, em verdade, na censura ao mau caráter de um cidadão, na censura à sua postura detestável diante do apreço de certas vidas. A censura configura, portanto, a tentativa de em uma imposição de uma determinada forma de viver, de ser, de bom viver. Retomando a didática imagem proposta por Dworkin, ou seja, a imagem de pessoas a nadarem em suas próprias raias, destacamos que cada um nada da forma que bem entender, desde que não atravesse a raia do próximo, que é dividida pelos códigos do direito, pelas suas regras, principiologicamente densificadas.

Assim, o hate speech não somente convive em um cenário que protege as liberdades, como também decorre e se pressupõe em um cenário onde cada indivíduo é tratado com igual consideração e respeito. Por isso, a aceitação do discurso do ódio não anula os postulados da igualdade e da liberdade, mas os complementa.

É certo que nenhum direito é absoluto, nem mesmo a liberdade de expressão. Não estamos aqui pregando que o discurso do ódio não tenha limites. Isso não se coadunaria com toda a coerência da teoria dworkineana a qual defendemos.

Lembremo-nos da linha divisória que separa a liberdade de expressão na forma do discurso do ódio e a pretensão abusiva discriminatória racial. Além disso, negaremos o argumento segundo o qual a existência do discurso do ódio anula ou viola as leis antidiscriminatórias.

Para isso, Dworkin, mais uma vez, ressalta a importância da distinção entre argumentos de princípio e argumentos de política, em especial, no caso em discussão. 
À luz das justificativas de princípio "uma forma específica é necessária para proteger um direito individual que alguém (ou, talvez, um grupo) tenha contra outras pessoas ou contra a sociedade ou contra o governo como um todo". É o caso das leis antidiscriminação. ${ }^{608}$

É importante compreender que a proteção à existência de leis antidiscriminatórias, que decorrem de argumentos de princípio, de modo algum resvala em incoerência com a disposição da liberdade de expressão defendida por Dworkin, incluindo-se, aqui, a livre expressão do discurso do ódio, que também consiste em um argumento de princípio, e pressuposto do respeito à voz igual e à independência ética que todos os indivíduos possuem enquanto verdadeiros trunfos contra o Estado e seus argumentos de política. Ressalte-se que a existência de leis antidiscriminatórias é exigência do postulado da igual consideração e respeito e isso não implica na censura ao discurso do ódio. Também não estamos dizendo que a liberdade de expressão e o conseguinte discurso do ódio configurem direito absoluto, irrestringível. A convivência entre as leis antidiscriminatórias e o discurso do ódio se complementam e se pressupõem a partir da compreensão de onde se encontra o delineamento que as divide. Ora, leis antidiscriminação proíbem a discriminação e o preconceito enquanto perigos graves, iminentes e reais. São leis que tipificam condutas como o preconceito na oferta de emprego ou habitação, por exemplo. Essas leis justificam-se em argumentos de princípio, pois "os indivíduos realmente têm um direito de não serem prejudicados na distribuição de recursos importantes porque outros sentem desprezo pela sua raça". Assim, o reinado da igual consideração e respeito atende ao imperativo da inclusão de minorias, na medida em que impõe o igual acesso a todos a ambientes físicos, a oportunidades de emprego, à saúde, e à voz igual, independentemente de sua cor, origem étnica, religião ou não religião, opção sexual. Aqui afirmamos que o direito à voz igual dos detestáveis também se inclui, sem que isso acarrete na exclusão das minorias.

Contrariamente, as justificativas de política "sustentam que uma norma específica é desejável porque trabalhará pelo interesse geral, isto é, pelo benefício da sociedade como um todo". 609

Tal diferenciação não impede que uma determinada norma seja justificada pelos dois tipos de argumentos. Mas a distinção ganha importância especial quando princípio e política argumentam em sentidos opostos e, quando isso acontece, a menos que as considerações de

\footnotetext{
${ }^{608}$ DWORKIN, Ronald. Uma questão de princípio. Título original: A Matter of Principle. Tradução de Luís Carlos Borges. 2. ed. São Paulo: Martins Fontes, 2005, p. 558.

${ }^{609}$ DWORKIN, Ronald. Uma questão de princípio. Título original: A Matter of Principle. Tradução de Luís Carlos Borges. 2. ed. São Paulo: Martins Fontes, 2005, p. 558 - 59.
} 
política tenham importância crucial, de maneira que a comunidade venha a sofrer uma catástrofe real se tais considerações forem ignoradas, a política deverá ceder ao princípio. ${ }^{610}$

Esse é um raciocínio que nos permite, com clareza e segurança, afirmar o quanto a liberdade de expressão queda-se diminuída e depreciada se a enxergamos com as cores de argumentos de política, baseados na utilidade geral.

\title{
4. HITLER CENSURADO: A DECISÃO BRASILEIRA QUE ORDENOU O RECOLHIMENTO DO LIVRO "MEIN KAMPF"
}

Em fevereiro de 2016, o pedido do Ministério Público do Estado do Rio de Janeiro foi atendido, em primeiro grau, pelo juiz Alberto Salomão Junior, da $33^{\mathrm{a}}$ Vara Criminal da Capital, que determinou a proibição no Rio de Janeiro da comercialização, exposição e divulgação do livro "Mein Kampf - Minha Luta", de Adolf Hitler, escrito em 1925 pelo líder nazista. A decisão amparou-se na prevalência da tutela dos direitos humanos, em detrimento de atos discriminatórios e incentivadores de ódio e violência, encontrando respaldo no precedente do caso Ellwanger. Nesse sentido, o juiz destacou que:

\begin{abstract}
(...) a venda de livros que veiculam ideias e ideais nazistas ferem gravemente a ordem pública, pois afronta a norma penal insculpida no artigo $20 \S 2^{\circ}$, da Lei $n^{\circ}$ 7.716/89 (...). Registre-se que a questão relevante a ser conhecida por este juízo é a proteção dos direitos humanos de pessoas que possam vir a ser vítimas do nazismo, bem como a memória daqueles que já foram vitimados. A obra em questão tem o condão de fomentar a lamentável prática que a história demonstrou ser responsável pela morte de milhões de pessoas inocentes, sobretudo, nos episódios ligados à Segunda Guerra Mundial e seus horrores oriundos do nazismo preconizado por Adolf Hitler. ${ }^{611}$
\end{abstract}

Sabemos que a autobiografia de Hitler "caiu em domínio público", fazendo parte do conjunto de obras não mais protegidas pelos direitos autorais. A proibição do livro não é, portanto, uma questão patrimonial de direito autoral, mas uma restrição estatal fundamentada num suposto risco de práticas racistas.

É certo e inegável o cunho altamente reprovável da obra, que defendia práticas denegridoras, discriminatórias e violadoras de certas vidas humanas, hoje reconhecidamente intoleráveis.

No entanto, a censura esquece-se de alguns detalhes peculiares da obra. Mais que um culto ao nazismo, a obra de Hitler, em virtude das consequências fáticas da tentativa de

\footnotetext{
${ }^{610}$ DWORKIN, Ronald. Uma questão de princípio. Título original: A Matter of Principle. Tradução de Luís Carlos Borges. 2. ed. São Paulo: Martins Fontes, 2005, p. 559.

${ }^{611}$ PODER JUDICIÁRIO DO ESTADO DO RIO DE JANEIRO, JUÍZO DE DIREITO DA $33^{\text {a }}$ VARA CRIMINAL DA CAPITAL. Decisão. Disponível em: <http://s.conjur.com.br/d1/livro-hitler-rj.pdf >. Acesso em fev. 2016.
} 
concretização teórica, é considerada um documento de cunho nitidamente histórico. Nesse sentido, "não é uma leitura apenas por prazer que se pode extrair da obra, mas uma chance analítica de observar um documento que levou milhares de pessoas a seguir um entendimento assassino e discriminatório". ${ }^{612}$ Assim, as raízes dos piores males da civilização humana também são objeto de uma análise capaz de ensejar pesquisas produtivas.

A censura à referida obra destina-se a proteger os valores da sociedade, de forma a afastar a propagação das ideias da obra de sua leitura. Convenhamos, no entanto, que o risco está no mal que a leitura da obra pode provocar, sendo, por isso, especulativo. É justamente esse, mais uma vez, o problema: a censura com base em argumentos especulativos de utilidade geral.

Vejamos o outro lado: imaginemos o leitor que, desavisadamente leia o livro hitleriano e aceite as ideias nele contidas como concebíveis e dignas de serem seguidas. Percebemos que, antes de ser vítima da "magia" das palavras, o leitor já possuía, em si, uma semente de ódio recrudescido implantada, que encontrou no livro a água para brotar sua manifestação discriminatória. Portanto, não podemos, nem conseguimos, permear e controlar o âmbito subjetivo da mente das pessoas. Da mesma forma, não podemos controlar nem evitar que pessoas de origem judaica sintam-se ofendidas com o pensamento de outrem, desde que, ressalte-se, esse pensamento não se concretize em atos, de fato, discriminatórios, como, por exemplo, impedir o acesso de judeus em um restaurante, ou negar-lhes acesso a um cargo de emprego por terem essa origem étnica. $\mathrm{O}$ que aqui exemplificamos se estende, obviamente, a quaisquer minorias, que são merecedoras de proteção estatal, ao atendimento da exigência da igualdade e respeito que lhes são deferidos.

Ademais, faz-se pertinente o seguinte raciocínio:

Somente quando aquele intolerante estiver a colocar em risco a própria ordem democrática, o que só se pode fazer por meio de ações e jamais por simples expressões do pensamento, transmissão de ideias e publicação de livros, é que se poderá tolher o intolerante. Trata-se de fazer aos nazistas de hoje o que os nazistas do passado não souberam fazer com os democratas de ontem. ${ }^{613}$

A censura à liberdade de expressão poderia representar um risco à publicação, por exemplo, de obras de Agatha Christie, "a rainha do crime", por representarem um risco de contaminar os leitores pela sanha homicida de matar seus rivais porque o vilão da história

\footnotetext{
${ }^{612}$ LIMA, Lucas Correia de. Hitler censurado!. In: Mega Jurídico. Disponível em: < http://www.megajuridico.com/hitler-censurado/>. Acesso em fev. 2016.

${ }^{613}$ COSTA NETO, João. Dignidade humana. Visão do Tribunal Constitucional Federal Alemão, do STF e do Tribunal Europeu. São Paulo: Saraiva, 2014, p.48.
} 
assim o fez. Isso configura um insulto aos cidadãos. Ronald Dworkin afirma, nesse sentido, que "o Estado insulta os seus cidadãos e nega a eles responsabilidade moral, quando decreta que não se pode confiar neles para ouvir opiniões que possam persuadi-los a adotar convicções perigosas ou ofensivas". 614

A partir da referida decisão, percebemos, uma vez mais, que o contexto jurídico brasileiro não possibilita o convívio da liberdade de expressão no mesmo cenário das leis antidiscriminatórias, por traçar a linha divisória um pouco antes do momento em que o discurso do ódio configura uma violação, de fato, discriminatória.

${ }^{614}$ DWORKIN, Ronald. O direito de liberdade: a leitura moral da Constituição americana. Trad. Marcelo Brandão Cipolla. São Paulo: Martins Fontes, 2006, p. 319. 


\section{CONCLUSÃO}

O atual paradigma moderno, a saber, o Estado Democrático de Direito, constitucionalmente consagrado no Brasil, é fruto do giro linguístico orientado por um ordenamento principiológico enquanto exigência da própria sociedade democrática, que pressupõe, enquanto ideia central, o reinado da igualdade.

No intento de aclamar o projeto iluminista de conferir luz às trevas, o positivismo resvalou por criar o maior dos mitos, o mito da perfeição científica, a crença em um método heurístico. É possível verificar que a prevalência do positivismo jurídico implementador do paradigma do Estado Social ainda ocupa espaço não só como marco teórico explícito, senão como "pano de fundo tacitamente acolhido" ${ }^{615}$ que insiste em orientar o ensino e a prática aos vários operadores jurídicos.

A partir da década de 90, as lições trazidas por dois notáveis filósofos do Direito contemporâneo - Ronald Dworkin e Robert Alexy -, ensejaram a virada principiológica na literatura jurídica mundial. Os direitos fundamentais foram ressignificados, na medida em que cada geração foi capaz de revisitar elementos herdados pelo passado, conferindo-lhe novas cores, refletidas em desafios futuros.

Para uma melhor compreensão das concepções acerca das regras e dos princípios, intentou-se analisar os critérios clássicos distintivos entre eles, a saber, as distinções quantitativas e as qualitativas. A partir de então, conseguimos enxergar, racionalmente inspirados pelo modelo normativo dos princípios, que as normas gerais e abstratas são incapazes de regular suas próprias condições de aplicação e que a pretensão de Alexy revelase como uma tentativa de controlar metodologicamente a indeterminação estrutural do Direito.

Analisamos o debate entre as considerações trazidas pelas teorias interna e externa dos direitos fundamentais. Propõe a teoria externa a visão dos direitos como, a princípio, ilimitados, que encontrarão reservas em atos externos legislativos ou judiciais. Contudo, o problema do Direito moderno não encontra solução através da edição de normas, pelo contrário, depara-se com o desafio da aplicação adequada de normas gerais e abstratas a situações de vida sempre individualizadas e concretas, à situação de aplicação, sempre única e irrepetível, por definição. Destarte, a complexidade do Direito requer irmos além da edição de normas. Considerar a unicidade de cada caso é reflexo do alerta de que pretensões abusivas

${ }^{615}$ CARVALHO NETTO, Menelick de; SCOTTI, Guilherme. Os Direitos Fundamentais e a (in)certeza do Direito: a produtividade das tensões principiológicas e a superação do sistema de regras. Belo Horizonte: Editora Fórum, 2011, p. 10. 
possam encontrar refúgio e travestir-se por trás das normas. Por isso necessitamos de uma visão de integridade no Direito. A teoria interna, então, atende a uma leitura principiológica e sistêmica da Constituição. Ora, independentemente de menções externas, todo direito individual deve cumprir uma função social, o que é intrínseco ao seu próprio sentido. $\mathrm{O}$ sentido - interno - de um direito fundamental é a própria densificação de valores clamados pela própria comunidade de princípios.

A emancipação do Direito moderno de fundamentos sagrados e metafísicos permitiu uma passagem ao momento da indisponibilidade, que se afirma no sentido de "validade deontológica dos direitos", sinalizador de uma averiguação, orientada por princípios, das "únicas decisões corretas". ${ }^{616}$ É neste momento que se admite a complexidade do modelo de um ordenamento de princípios, que se apresenta por inteiro, e que permite o reconhecimento de uma tensão produtiva e reciprocamente constitutiva, da qual se extrai a única decisão correta mediante um esforço interpretativo, capaz de distinguir argumentos de princípio de argumentos de política diante de cada caso concreto, único e irrepetível. Esse esforço interpretativo é, portanto, exigência de que os direitos sejam levados a sério. Neste momento, valemo-nos das palavras de Dworkin: “We are governed not by a list but by an ideal, and controversy is therefore at the heart of our story". 617

À luz dessa perspectiva, rechaçamos o apego à aplicação de um direito metodológico e metafísico, é dizer, a recorrência ao erro mitológico baseado na crença em um método heurístico, supostamente capaz de garantia de certezas. Insuflados pelo excesso do Estado Social, podemos aprender que não é possível regular todas as situações formadoras de casos que estão se formando, neste exato momento. $\mathrm{O}$ recurso ao método com a pretensão de que ele garante certezas, na maioria das vezes, amparadas pela perquirição de fórmulas matemáticas, leva a teoria dos direitos fundamentais de Alexy a um resultado de aplicação prática que nem sempre atenderá ao respeito de direitos enquanto trunfos.

Dessa forma, a perspectiva axiológica dos direitos, o uso da técnica da ponderação, e da máxima da proporcionalidade, em Alexy, acaba por tratar o Direito e a Constituição enquanto uma ordem concreta de valores enxergados como passíveis de gradação em casos de conflito. Verificamos que o problema não está em tratar os princípios e o Direito como um todo enquanto valor. O que não devemos é resvalar-nos na ideia de que valores entrem em conflito, tendo em vista que é possível uma teoria capaz de unificar os valores em um todo

\footnotetext{
${ }^{616}$ HABERMAS, Jürgen. Direito e democracia: entre facticidade e validade, vol. I, 2.ed., tradução: Flávio Beno Siebeneichler. Rio de Janeiro: Tempo Brasileiro, 2012, p. 259.

${ }^{617}$ Cf. DWORKIN, Ronald. The concept of non enumerated rights. In: University of Chicago Law Review. Vol. 59, 1992.
} 
coerente, o que delineia a ideia de integridade no direito, a Justiça de ouriços. O valor é uma coisa muito importante. O empréstimo da citação do dramaturgo grego Arquíloco, segundo o qual "a raposa sabe muitas coisas, e o ouriço sabe uma só, mas o que o ouriço sabe é muito importante" é utilizado em "Justice for Hedgehogs" tese principal da unidade do valor. E se o valor é tão importante, não devemos aplicá-lo na maior medida possível de sua satisfação, como pretende o método da proporcionalidade, mas sim a partir da compreensão coerente ao seu sentido, analisando se o valor vale ou não. A Justiça de ouriços é, portanto, formada por um tecido que se interliga através de fios argumentativos estruturalmente coerentes.

É nesse sentido que Dworkin sugere um processo interpretativo integrativo, que "busca compreender cada parte e cada filamento do valor à luz das outras partes e filamentos". 619

A aplicação de princípios como preceitos de otimização pelas doutrinas metodológicas, no mínimo, inibe o caráter de validade deontológica dos princípios. Portanto, a leitura alexiana convida os direitos fundamentais a caírem em uma análise de custos e vantagens, mesclando-os com determinações de objetivos, ou seja, com argumentos de política.

Em vez de serem as normas mandamentos de otimização, elas serão ou adequadas, ou não adequadas. E, adequação, nesse sentido, significa "a validade de um juízo deduzido de uma norma válida, através do qual a norma subjacente é satisfeita". Portanto, "uma jurisprudência orientada por princípios precisa definir qual pretensão e qual ação deve ser exigida num determinado conflito", ao invés de "arbitrar sobre o equilíbrio de bens ou sobre o relacionamento entre os valores", 620

É assim que nos deparamos com o ordenamento principiológico tecido por Dworkin, que supera o questionamento acerca do que é a Constituição, preferindo demonstrar o que ela constitui. No célebre debate com Posner acerca do tema dos direitos implícitos, Dworkin afirma não ser partidário da distinção entre direitos constitucionais expressos (enumerated rights) e implícitos (unenumerated rights), tendo em vista que a história jurídica tem rejeitado uma interpretação estreita e, no entanto, no momento em que compreendemos que os dispositivos constitucionais são tão substantivos quanto procedimentais, o seu âmbito revela-

\footnotetext{
${ }^{618}$ DWORKIN, Ronald. A raposa e o porco-espinho: justiça e valor. Tradução de Marcelo Brandão Cipolla. São Paulo: Editora WMF Martins Fontes, 2014.

${ }^{619}$ DWORKIN, Ronald. A raposa e o porco-espinho: justiça e valor. Tradução de Marcelo Brandão Cipolla. São Paulo: Editora WMF Martins Fontes, 2014, p. 180-183.

${ }^{620}$ HABERMAS, Jürgen. Direito e democracia: entre facticidade e validade, vol. I, 2.ed., tradução: Flávio Beno Siebeneichler. Rio de Janeiro: Tempo Brasileiro, 2012, p. 322-323.
} 
se de uma amplitude espantosa (breathtaking). Com isso, fica claro que a Bill of Rights, nas palavras de Dworkin, "orders nothing less than that government treat everyone subject to its dominion with equal concern and respect, and that it not infringe their most basic freedoms, those liberties essential". 621

Nesse ínterim, o caráter interpretativo do argumento ganha destaque, e exclui qualquer limite semântico que a distinção impõe. Assim, “a interpretação jurídica é essencialmente holística, ainda quando o alvo aparente da interpretação seja um determinado dispositivo ou expressão e não o documento como um todo". ${ }^{62}$ Nesse sentido, Dworkin alerta-nos, uma vez mais, para a não existência de uma fórmula capaz de garantir que todos os juízes alcançarão a mesma resposta nos casos constitucionais cruciais, novos ou complexos. Assim, é nítido o grito de Dworkin, segundo o qual a recorribilidade a fórmulas não é garantia de defesa contra más decisões: "No formula can protect us (...)". 623

Com isso, ao invés de buscarmos o falso amparo de uma fórmula, orientamos nossa interpretação jurídica rumo ao limite independente e superior da integridade (an independent and superior constraint of integrity ${ }^{624}$ ), que insiste que a decisão judicial seja uma questão de princípio, e não um compromisso ou uma estratégia de acomodação política.

Compreendemos, portanto, que Dworkin apregoa que a Constituição constitui uma comunidade de princípios, é dizer, uma comunidade fundada sobre princípios, calcada no reconhecimento recíproco da igualdade e da liberdade de todos e cada um de seus membros. Esse cenário é figurado pela recepção do abstrato conteúdo moral pelo Direito que, por sua vez, confere maior densidade e concretude a esse conteúdo, que o torna legítimo. Esse conteúdo moral, então, passa a ser incorporado ao Direito enquanto direitos fundamentais e princípios constitucionais. ${ }^{625}$

Mas então qual é o ajuste político exigido por essa comunidade de princípios? Quando a aplicação dos direitos é levada a sério?

Sob a ótica de uma teoria moderada de direitos contra o Estado, a reivindicação de um direito é entendida, no sentido restrito, como um "tipo de juízo sobre o que é certo ou errado

\footnotetext{
${ }^{621}$ DWORKIN, Ronald. The concept of non enumerated rights. In: University of Chicago Law Review. Vol. 59, 1992, p. 382.

${ }^{622}$ DWORKIN, Ronald. The concept of non enumerated rights. In: University of Chicago Law Review. Vol. 59, 1992 , p. 384 e ss.

${ }^{623}$ DWORKIN, Ronald. The concept of non enumerated rights. In: University of Chicago Law Review. Vol. 59, 1992, p. 393.

${ }^{624}$ DWORKIN, Ronald. The concept of non enumerated rights. In: University of Chicago Law Review. Vol. 59, 1992 , p. 393.

${ }^{625}$ NETTO, Menelick de Carvalho; SCOTTI, Guilherme. Os Direitos Fundamentais e a (in)certeza do Direito: a produtividade das tensões principiológicas e a superação do sistema de regras. Editora Fórum, 2011, p. 71-72.
} 
que os aplicadores do direito façam". ${ }^{626}$ Dessa forma, Dworkin confirma que um homem possui um direito contra o Estado, "se pudermos mostrar que este comete um erro ao tratá-lo de uma determinada maneira, ainda que o faça tendo em vista o interesse geral". ${ }^{627}$

Ao encararmos os direitos de tal forma, podemos afirmar, despidos de estranheza, "que os direitos podem variar em força e características de um caso para outro e de um momento a outro na história". ${ }^{628}$ Assim, o contexto pertencente ao paradigma vivido por cada momento permite a ressignificação da importância que cada direito ocupa na comunidade de princípios.

A existência de um direito contra o Estado, então, nos conduz à compreensão de que temos o direito de fazer algo mesmo quando a maioria considera errado fazer tal coisa, ainda que a maioria reste prejudicada em razão disso. Mas que direitos são esses, tão fortes que são capazes de se configurarem como um escudo contra o Estado e contra a maioria? São os verdadeiros trunfos que temos contra o Estado, são direitos fundamentais especiais, são direitos-trunfos sobre a utilidade geral. E negar tal característica é negar a própria existência desses direitos. Logo, aos trunfos não deve se sobrepor a perspectiva de ganhos utilitaristas.

Qual o risco dos argumentos utilitaristas? Qual o risco da maioria? A afirmação de que um homem possui um direito a fazer algo, ainda que a maioria fique com isso prejudicada pode soar muito radical se não compreendermos a noção de que um homem possui direitos fortes contra o Estado. Lembremo-nos que a preservação de uma gama de direitos que agasalham a maioria social depende, em verdade, de reconhecermos enquanto direitos concorrentes apenas aqueles pertencentes a outros membros da sociedade, tomados como indivíduos. Nessa esteira, apontamos a diferenciação-chave na teoria dworkineana entre argumentos de princípio, que são destinados a estabelecer um direito individual, e argumentos de política, que são destinados a estabelecer um objetivo coletivo. ${ }^{629}$

Mas, ainda assim, por que devemos criticar o fato de uma maioria democrática fazer valer sua vontade?

O utilitarismo pode ser localizado enquanto grupo proeminente das teorias que se ancoram na argumentação orientada sobre qual deve ser o objetivo da ação política, em prol de um bem-estar da comunidade. O utilitarismo, portanto, "supõe que a comunidade está em

\footnotetext{
${ }^{626}$ DWORKIN, Ronald. Levando os direitos a sério. Tradução: Nelson Boeira, 3.ed. São Paulo: Editora WMF Martins Fontes, 2010, p. 218.

${ }^{627}$ DWORKIN, Ronald. Levando os direitos a sério. Tradução: Nelson Boeira, 3.ed. São Paulo: Editora WMF Martins Fontes, 2010, p. 218.

${ }^{628}$ DWORKIN, Ronald. Levando os direitos a sério. Tradução: Nelson Boeira, 3.ed. São Paulo: Editora WMF Martins Fontes, 2010, p. 218.

${ }^{629}$ DWORKIN, Ronald. Levando os direitos a sério. Tradução: Nelson Boeira, 3.ed. São Paulo: Editora WMF Martins Fontes, 2010, p. 141.
} 
melhor situação se seus membros forem, na média, mais felizes ou se tiverem mais preferências satisfeitas". 630

$\mathrm{Na}$ política das democracias ocidentais, percebemos que o direito tende a conferir prevalência a justificativas utilitaristas enquanto justificativas de fundo sobre decisões políticas. Os argumentos utilitaristas figuram, hoje, as justificativas mais influentes. Destarte, "o utilitarismo deve seu apelo, qualquer que seja ele, ao que poderíamos chamar de seu matiz igualitário", 631 que, por sua vez, convida as pessoas serem tratadas como iguais, levando em conta os desejos dos membros da comunidade com equivalência. $\mathrm{O}$ argumento utilitarista é, portanto, atraentemente encantador. Não obstante, verificamos que o caráter igualitário de um argumento utilitarista é frequentemente uma ilusão, tendo em vista que "é impossível conceber procedimentos políticos que discriminem com precisão entre preferências pessoais e externas". 632

Nesse sentido, acatamos a crítica dworkineana à democracia representativa: ela funciona imperfeitamente, pois a regra de decisão pela maioria não consegue levar suficientemente em conta a intensidade das preferências particulares, ou seja, ela não é capaz de discriminar os componentes pessoais - convicções que o indivíduo escolhe para si mesmos -, dos externos - preferências para impor uma forma de vida apropriada às outras pessoas.

O utilitarismo, é possível dizer, ampara-se em motivos de preferências morais sobre como os outros devem comportar-se.

Sem o intento de desprezar as qualidades e os benefícios da democracia representativa, é importante, contudo, alertar para o risco de imposições advindas pelas maiorias. Qual seria o perigo das maiorias? É também neste ponto que a crítica tecida por Dworkin aos argumentos utilitaristas coaduna-se com o discurso comunicativo habermasiano.

Nesse cenário, lembremo-nos do lado obscuro do pressuposto da homogeneidade nacional, demandada por Carl Schmitt, que implicaria em unidade política, na retomada da ideia grega de democracia enquanto identidade substantiva entre governante e governado. A ideia de democracia, para Schmitt, pode ser facilmente resgatada na forma de uma ditadura. Ao considerar o pressuposto da homogeneidade do povo, Schmitt desconsidera a intersubjetividade dos cidadãos - direitos fundamentais e uso das liberdades subjetivas. Quando uma democracia é introduzida com a ideia de auto-afirmação coletiva, o cidadão não

\footnotetext{
${ }^{630}$ DWORKIN, Ronald. Uma questão de princípio. Título original: A Matter of Principle. Tradução de Luís Carlos Borges. 2. ed. São Paulo: Martins Fontes, 2005, p. 534.

${ }^{631}$ DWORKIN, Ronald. Uma questão de princípio. Título original: A Matter of Principle. Tradução de Luís Carlos Borges. 2. ed. São Paulo: Martins Fontes, 2005, p. 537.

${ }^{632}$ DWORKIN, Ronald. Levando os direitos a sério. Tradução: Nelson Boeira, 3.ed. São Paulo: Editora WMF Martins Fontes, 2010, p. 425.
} 
consegue exercer uma série de direitos fundamentais fora do contexto de um povo constituído em nação. ${ }^{633}$ A homogeneidade destaca o inimigo, que é caçado e eliminado, mas, sobretudo, essencial para a formação de uma unidade política, onde antes não havia. Devemos, portanto, direcionar nossas lutas por uma ordem política aberta que inclua marginalizados sem confinálos na ideia de comunidade homogênea de um povo.

Vale apontar, dessa forma, para o risco de uma cultura majoritária dominante, que impinge invisivelmente regras repressivas, ainda que inserta em uma comunidade republicana que garanta formalmente a igualdade de direitos para todos.

Preocupamo-nos, portanto, com o utilitarismo irrestrito, que conduz a resultados evidentemente inegualitários. Como resposta aos defeitos filosóficos do utilitarismo, Dworkin elabora uma teoria geral dos direitos baseada no conceito de direito político individual, no sentido antiutilitarista forte ${ }^{634}$.

Levar os direitos a sério pressupõe a orientação de nossos atos pelo reinado de dois princípios legitimadores do atual paradigma democrático: igual consideração e respeito (equal concern); e respeito às responsabilidades individuais (equal respect for responsability).

A violação de um direito em sentido forte é uma questão muito séria. Significa "tratar um homem como menos que um homem ou como se fosse menos digno de consideração que outros homens", o que insistiria em violar o trunfo da dignidade humana. ${ }^{635}$

Nesse sentido, Dworkin acrescenta que os princípios de dignidade declaram direitos políticos muito abstratos, que ganham, como trunfos, das políticas coletivas do governo; e que "todos os direitos políticos derivam desse direito fundamental". ${ }^{636}$ No que tange à universalidade da dignidade humana, Dworkin afirma que o juízo interpretativo deve ser sensível às diferenças. Porém, a compreensão básica de que a dignidade humana exige preocupação e respeito iguais e o respeito pela responsabilidade pessoal compõe um "padrão abstrato" que não é relativo, mas "genuinamente universal". 637

A teoria substantiva dos direitos políticos como trunfos é construída sobre os conceitos interpretativos principais dos dois princípios fundamentais da dignidade, "de modo

\footnotetext{
${ }^{633}$ HABERMAS, Jürgen. A Inclusão do Outro: estudos de teoria política. São Paulo: Loyola, 2002, p. 153-155.

${ }^{634}$ DWORKIN, Ronald. Levando os direitos a sério. Tradução: Nelson Boeira, 3.ed. São Paulo: Editora WMF Martins Fontes, 2010, p. 426.

${ }^{635}$ DWORKIN, Ronald. Levando os direitos a sério. Tradução: Nelson Boeira, 3.ed. São Paulo: Editora WMF Martins Fontes, 2010, p. 305 e ss.

${ }^{636}$ DWORKIN, Ronald. A raposa e o porco-espinho: justiça e valor. Tradução de Marcelo Brandão Cipolla. São Paulo: Editora WMF Martins Fontes, 2014, p. 504.

${ }^{637}$ DWORKIN, Ronald. A raposa e o porco-espinho: justiça e valor. Tradução de Marcelo Brandão Cipolla. São Paulo: Editora WMF Martins Fontes, 2014, p. 507-517.
} 
que cada um deles complemente o outro e o reforce". ${ }^{638}$ Para isso, a teoria de Dworkin rejeita a opinião ainda popular de que a liberdade e a igualdade são valores conflitantes. Nesse sentido, podemos ressignificar a noção tradicional e ultrapassada que resvala na tensão entre esses dois conceitos. Torna-se possível, e mais que isso, crucial, que reconciliemos as noções de igualdade e liberdade.

Os postulados dworkineanos são melhor compreendidos a partir do aprofundamento da concepção de liberdade e igualdade enquanto princípios conjuntos, inextricavelmente ligados: A partir de então, podemos percorrer um verdadeiro tecido unitário, que se interliga coerentemente mediante fios condutores argumentativos.

Verificamos, com frequência, a inserção de grandes questões sociais de política interna e, em particular, a questão racial em paradigmas onde as exigências da liberdade e da igualdade conflituam entre si. Nesse sentido, é possível que os pobres, os negros, os trabalhadores não especializados, os carentes de educação, as mulheres, os idosos, os homossexuais, por exemplo, tenham um direito abstrato à igualdade. Não obstante, os prósperos, os brancos, os instruídos, e os trabalhadores especializados, os homens, os heterossexuais, também têm um direito à liberdade. Portanto, os dois conjuntos de direitos merecem consideração e respeito.

A partir da tensão entre igualdade e liberdade, perguntamos: Afinal de contas, temos um direito à liberdade? Se temos direito a liberdades, então devemos compreender que os demais também possuem esse direito em igual quota de respeito.

A definição tradicional de sentido neutro e abrangente de liberdade enquanto licença desemboca, inevitavelmente, na competição entre liberdade e igualdade. Ora, leis são necessárias para proteger a igualdade e, inevitavelmente, envolverão limitações à liberdade. Portanto, o sentido neutro da liberdade parece causar mais confusão que esclarecimento, pois dilui a noção de direito e enfraquece a de liberdade, uma vez que, sob a perspectiva clássica, uma pessoa tem um direito à liberdade se for de seu interesse ter essa liberdade, e o "querer" liberdade não exige nenhuma concessão quanto aos esforços necessários para conferir a outros homens a igualdade que é sua prerrogativa. Verifica-se, a partir de então, que a liberdade precisa configurar um direito muito mais forte para que desempenhe o papel a ela talhado no debate político. Inexiste, portanto, um direito geral à liberdade.

Então por que determinadas restrições à liberdade são consideradas injustas, e outras, não? Por que há restrições à liberdade que ocasionam um impacto especial sobre a liberdade

\footnotetext{
${ }^{638}$ DWORKIN, Ronald. A raposa e o porco-espinho: justiça e valor. Tradução de Marcelo Brandão Cipolla. São Paulo: Editora WMF Martins Fontes, 2014, p. 504-505.
} 
enquanto tal? Por que, em uma democracia, os cidadãos têm direitos a algum tipo específico de liberdade, como a liberdade de expressão e a liberdade religiosa?

Devido à incapacidade de defender os direitos enquanto tais, buscamos um argumento para além da utilidade geral.

$\mathrm{O}$ postulado orientador exigido pela justiça corresponde à igual consideração $e$ respeito. Chegamos a um momento muito importante do nosso estudo: a compreensão de que os direitos individuais a diferentes liberdades devem ser reconhecidos somente quando se puder mostrar que o direito fundamental a ser tratado como igual (treatment as an equal) exige tais direitos. Dessa forma, se uma determinada liberdade for exigida pelo princípio da igual consideração e respeito, então ela merece reconhecimento enquanto um direito forte, um verdadeiro trunfo contra o Estado.

A teoria da liberdade sugerida por Dworkin é agraciada por uma universalidade indiscutível. Que liberdades temos, de fato? Qual o alcance pode tomar o édito estatal em minha vida?

Dworkin $^{639}$ realiza uma estipulação terminológica para aclarar o conceito de liberdade: "freedom" configura a autonomia total de uma pessoa, a sua capacidade de agir como quiser, livre de condicionalismos ou ameaças impostas por outros ou por uma comunidade política. Já a liberdade negativa, ou apenas liberdade (liberty), é a porção da sua autonomia que uma comunidade não lhe pode retirar sem a ofender de algum modo especial, comprometendo a sua dignidade, ao negar-lhe a preocupação igual ou uma característica essencial da responsabilidade pela sua própria vida. ${ }^{640}$

Destarte, freedom e liberty não se confundem, porque não são coextensivas, logo, qualquer limite à primeira não implica numa invasão à segunda. Portanto, o Estado não compromete a liberdade dos cidadãos nem os insulta quando os proíbe de matar uns aos outros, por exemplo. Pelo contrário, nossa dignidade enquanto cidadãos exige que o Estado nos proteja dessa maneira. Portanto, a liberdade não seria uma autonomia total, mas autonomia substancial. Mas como medir uma quantidade de autonomia perdida mediante uma lei em particular?

Tal questionamento encontra resposta justamente no delineamento traçado por um valor mais profundo, a saber, o da responsabilidade pessoal ou independência ética (ethical independence).

\footnotetext{
${ }^{639}$ DWORKIN, Ronald. Justice for Hedgehogs. Keynote address. In: Boston University. Disponível em: < http://www.bu.edu/law/journals-archive/bulr/documents/dworkin_k.pdf>. Acesso em 15 fev. 2015.

${ }^{640}$ DWORKIN, Ronald. A raposa e o porco-espinho: justiça e valor. Tradução de Marcelo Brandão Cipolla. São Paulo: Editora WMF Martins Fontes, 2014, p. 561.
} 
Vejamos um exemplo: não seria ofensiva a imposição de regras de trânsito - desde que não sejam disparatadas, ou que uma lei proíba as pessoas de matarem umas às outras, como já foi mencionado, ou que tenham direitos sobre suas propriedades. Não obstante, seria ofensivo para uma pessoa ter que aceitar que uma maioria impusesse uma determinada convicção religiosa, ou quais opiniões devem ou não ser seletivamente expressas em debates políticos.

Um Estado justo deve reconhecer que cada cidadão possui o direito à independência ética, que engloba as nossas escolhas no âmbito de questões essenciais, que envolvam valores éticos. Nas palavras de Dworkin: "We have a right to make fundamental choices about the meaning and importance of human life for ourselves."641

Quando o Estado nos pressiona a pagar impostos, a dirigir de forma cautelosa, quando nos proíbe de praticar atos de violência, por exemplo, ele utiliza-se de um argumento ou uma justificação moral, e não ética, e, portanto, não ofende nossa independência ética, tendo em vista que ele não nega nossa responsabilidade de definir valores éticos para nós mesmos, não usurpando nossa responsabilidade de identificar uma vida de sucesso. Assim, a independência ética não é ultrajada quando um assunto não é fundamental e as restrições estatais não supõem nenhuma justificativa ética.

Por outro lado, existem leis coercitivas que violam a independência ética por negarem às pessoas o poder de tomar suas próprias decisões acerca de questões éticas fundamentais. Sobre a trilha das questões fundamentais percorrem, por exemplo, as escolhas referentes à religião, as escolhas pessoais íntimas, os ideais éticos, morais e políticos. As pessoas possuem um direito a essa independência, desde que não coloquem em risco a igual independência de outras pessoas.

Há leis violadoras desse postulado por motivações nas quais o Estado se ampara ao promulgá-las, é quando a autonomia do indivíduo é restringida com base numa justificativa que pressuponha a superioridade ou a popularidade de quaisquer valores éticos controversos na comunidade. São leis que, por exemplo, censuram a literatura sexual e as que impõem a obrigatoriedade da saudação à bandeira. Ora, elas refletem uma imposição a uma escolha sobre as virtudes pessoais formadoras de uma boa vida. Ademais, há leis que violam a independência ética das todas as maneiras: é o caso da proibição do casamento entre pessoas do mesmo sexo e a censura política, por exemplo.

\footnotetext{
${ }^{641}$ DWORKIN, Ronald. Justice for Hedgehogs. Keynote address. In: Boston University, p. 471-472. Disponível em: < http://www.bu.edu/law/journals-archive/bulr/documents/dworkin_k.pdf>. Acesso em 15 fev. 2015.
} 
Assim, as leis com motivos adequados fazem parte do pano de fundo no qual faço as minhas escolhas éticas. A minha responsabilidade ética de fazer essas escolhas não é diminuída por esse pano de fundo. ${ }^{642}$

Qual o limite aceitável das decisões coletivas nas vidas das pessoas? Dworkin propõe uma interessante imagem: pessoas a nadarem em suas próprias raias, que podem passar para raias de outras para lhes auxiliar, mas não para lhes causar danos. A moral, entendida de modo amplo, define as raias que separam os nadadores. Estipula quando uma pessoa deve atravessar para ajudar e quando o atravessamento é danoso e proibido (seriam os códigos do direito). Já a ética rege o modo como uma pessoa deve nadar na sua própria raia para nadar bem. Essa imagem demonstra os aspectos da moral como anterior à ética na política: "deve ser considerada anterior na definição das oportunidades e recursos que as pessoas têm o direito de ter e, assim, no estabelecimento de seus direitos à liberdade". A partir dessa concepção interpretativa de liberdade Dworkin afirma ser possível compreender a não subordinação nem da moral à ética nem da ética à moral, já que "elas não competem, mas cooperam entre si”. ${ }^{643}$

A distinção entre os argumentos de princípio e os argumentos de política dá um salto considerável na teoria dworkineana. Ao discorrer sobre a censura, Dworkin assevera que a defesa da liberdade de expressão encontra guarida em argumentos de princípio, uma vez que decorre da independência ética.

Ressaltamos que a confusão entre política e princípio põe em risco o "genuíno e frágil direito à livre expressão", de forma que o risco de comprometer esse direito é maior que os benefícios advindos da política. Confundir os dois é um perigo à liberdade. Dworkin vai além: "A advertência é genérica. Se nos importamos tão pouco com o princípio que emprestamos suas cores à política quando isso serve a nosso propósito, depreciamos o princípio e diminuímos sua autoridade" ${ }^{644}$

É, portanto, imperiosa a diferenciação entre direitos e objetivos. Não devemos confundir um direito com um objetivo político, "a menos que ele tenha um certo peso contra as metas coletivas em geral", como uma meta de urgência especial, um perigo grave, concreto, real e iminente.

Suponhamos a seguinte situação: um homem diz que reconhece o direito à liberdade

\footnotetext{
${ }^{642}$ DWORKIN, Ronald. A raposa e o porco-espinho: justiça e valor. Tradução de Marcelo Brandão Cipolla. São Paulo: Editora WMF Martins Fontes, 2014, p. 565-566.

${ }^{643}$ DWORKIN, Ronald. A raposa e o porco-espinho: justiça e valor. Tradução de Marcelo Brandão Cipolla. São Paulo: Editora WMF Martins Fontes, 2014, p. 567-568.

${ }^{644}$ DWORKIN, Ronald. Uma questão de princípio. Título original: A Matter of Principle. Tradução de Luís Carlos Borges. 2. ed. São Paulo: Martins Fontes, 2005, p. 497 e ss.
} 
de expressão, mas acrescenta que tal liberdade deve ficar em segundo plano sempre que seu exercício possa ser inconveniente para o público. Ele reconhece a meta amplamente disseminada do bem-estar coletivo, mas reconhece a distribuição da liberdade de expressão apenas nos termos recomendados por essa meta coletiva para circunstâncias específicas. Sua posição política é, dessa forma, exaurida pela meta coletiva. O direito putativo nada acrescenta e não há nenhuma razão para reconhecê-lo como um direito. ${ }^{645}$

Esse é um raciocínio que nos permite, com clareza e segurança, afirmar o quanto a liberdade de expressão queda-se diminuída e depreciada se a enxergamos com as cores de argumentos de política, baseados na utilidade geral.

Portanto, uma solução política não respeita os direitos-trunfos e, por isso, deve-se buscar uma solução constitucional, que se configura numa exigência de justiça. Entregar os trunfos às considerações de pessoas diferentes, que farão avaliações diferentes, é correr o risco de se colher imperfeições e injustiças. O Direito constitucional norte-americano, diga-se de passagem, recusou-se a pagar esse preço e, portanto, tornou-se motivo de inveja de sistemas jurídicos mais formalistas.

Enfim, devemos advertir que a busca de uma solução constitucional, no lugar de uma solução política, não implica que os juízes não possam proferir decisões que sejam políticas em algum sentido. O que rejeitamos é o uso de fundamentos políticos para a tomada dessas decisões. Enquanto verdadeiros trunfos que são, os direitos fundamentais merecem ser tratados enquanto questão de princípio, portanto, a eles não se deve dirigir uma solução judicial baseada em argumentos de utilidade geral.

Não obstante, uma análise em torno de diversos casos julgados pelo Supremo Tribunal Federal, dentre eles, do caso Ellwanger, que será em breve retomado, permite-nos apontar que a referida Corte Constitucional, no lugar de uma leitura deontológica, realiza uma leitura axiológica da Constituição Federal, uma vez que, não raramente, opta pela solução de casos a partir da aplicação do princípio da proporcionalidade, utilizando-se, portanto da técnica de ponderação de bens, ou do sopesamento. Aqui, Damião Azevedo acrescenta que o Estado Democrático de Direito demanda a existência de uma democracia pluralista bem como a convivência entre diferentes formas de vida sem que seja necessário sopesar valores culturais existentes na sociedade, não devendo o juiz substituir os valores das partes pelos seus

\footnotetext{
${ }^{645}$ DWORKIN, Ronald. Levando os direitos a sério. Tradução: Nelson Boeira, 3.ed. São Paulo: Editora WMF Martins Fontes, 2010, p. 145.
} 
próprios ou por aquilo que acredita a melhor forma de bem-viver. ${ }^{646} \mathrm{Com}$ isso, é possível dizer que, ao utilizar o princípio da proporcionalidade para a solução dos conflitos entre normas, a nossa Corte Constitucional apresenta fundamentos que refletem uma confusão entre a política e Direito, entre argumentos de política e argumentos de princípios, o que compromete a concretização dos trunfos que cada cidadão possui.

Diante da tese da única decisão correta, os céticos (visão comum), que não concordam com ela, dirão que existem apenas respostas diferentes para a questão de direito e nenhuma resposta correta, ou melhor. Eles utilizam-se de argumentos como o da submissão dos juízes a instâncias mais representativas, como as legislativas, ou argumentos de que os juízes deverão pautar suas decisões de acordo com o que for melhor para o futuro da nação. ${ }^{647}$

No entanto, com o entendimento de que o argumento e a análise jurídica são dotados de caráter fundamentalmente interpretativo, esse desafio cético queda-se alterado e minimizado.

O cenário da única decisão correta assenta-se na unicidade e na irrepetibilidade inerentes a cada caso. Esse cenário é figurado pelo modelo de um ordenamento de princípios, onde mesmo as regras devem ser principiologicamente lidas. $\mathrm{O}$ ordenamento principiológico é complexamente formado por princípios reciprocamente constitutivos e igualmente válidos, que, por derradeiro, dependem do caso concreto. Essa leitura nos permite discernir pretensões abusivas da correta.

Robert Alexy releva-nos, aqui, e mais uma vez, sua incompreensão diante da tese da única resposta correta, uma vez que, para ele, ela pressupõe um consenso. Ora, a única resposta correta não depende de um real consenso sobre a sua correção, mas de uma postura hermenêutica diante do caso, que será regida pela comunidade principiológica exigida pela sociedade. $^{648}$

Chegamos, então, ao cenário ao qual ocupa a dimensão da liberdade de expressão sob a forma do discurso do ódio. Poderíamos apregoar tão somente sua crucialidade em um Estado que se supõe Democrático de Direito. Contudo, desejamos ir além. Ansiamos, despindo-nos de quaisquer pré-considerações, e de juízos passionais, enfrentar a incômoda questão do discurso do ódio ou hate speech.

\footnotetext{
${ }^{646}$ AZEVEDO, Damião Alves de. Ao encontro dos princípios: crítica à proporcionalidade como solução aos casos de conflito aparente de normas jurídicas, Pós-graduação lato sensu em Direito Público, 2008, p. 17. Disponível em: <http://moodle.cead.unb.br/agu/course/view.php?id=9>.

${ }^{647}$ DWORKIN, Ronald. Uma questão de princípio. Título original: A Matter of Principle. Tradução de Luís Carlos Borges. 2. ed. São Paulo: Martins Fontes, 2005, p. 175 e ss.

${ }^{648}$ CARVALHO NETTO, Menelick de; SCOTTI, Guilherme. Os Direitos Fundamentais e a (in)certeza do Direito: a produtividade das tensões principiológicas e a superação do sistema de regras. Belo Horizonte: Editora Fórum, 2011, p. 50 e ss.
} 
O hate speech pode ser compreendido como o discurso destinado a promover o ódio ou a aversão, por razões de sexo, origem étnica, nacionalidade ou religião. Esses discursos podem tomar a forma de palavras faladas, mensagens escritas, gestos ou outras modalidades de atos que insultam ou intimidam pessoas ou grupos. Nesse cenário, a Suprema Corte norteamericana tem conferido ampla proteção à liberdade de expressão, declarando a inconstitucionalidade das leis que procuraram restringir essa liberdade devido a inadequabilidade e na ofensa desses atos. De acordo com a Suprema Corte, a democracia pressupõe a proteção de todas as formas de expressão e, por conseguinte, a garantia de um debate aberto, vigoroso e desinibido. ${ }^{649}$

A teoria da liberdade (liberty) de Dworkin é dotada de notável coerência estrutural, podendo ser justificada por três tipos de argumento: (1) Necessitamos de algumas liberdades, particularmente, a liberdade de expressão (liberty of speech), pois liberdades desse tipo são necessárias a um justo e adequado sistema democrático de governo. (2) O direito à independência ética, que decorre do primado do igual respeito à responsabilidade dos cidadãos. Temos o direito de realizar escolhas fundamentais, por conta própria, sem interferência do Estado, sobre o significado e importância da vida humana, por exemplo. (3) O direito também baseado na independência ética, de não ter negada qualquer autonomia (freedom) quando a justificação do Estado repousar na popularidade ou na superioridade de algumas concepções sobre um modo melhor de vida a ser seguido. ${ }^{650}$

Não podemos negar que o direito à livre expressão ocupa lugar central na teoria tradicional dos direitos liberais e deve, para Dworkin, "ser tratado com mais sutileza".

Dworkin compreende que "uma estrutura constitucional que garante a liberdade de expressão contra a censura oficial protege os cidadãos em seu papel democrático como soberanos". Enquanto complementar à concepção de igualdade, a liberdade de expressão "resulta essencial para a associação democrática", devendo ser garantido o direito de se expressar qualquer opinião relevante, sem se importar se ditas opiniões são rechaçadas, odiadas ou temidas por outros cidadãos. ${ }^{651}$

Assim sendo, leis que proíbam marchas de neonazistas, por exemplo, “desfiguram a democracia”, uma vez que se uma maioria de cidadãos tem o poder de negar a um concidadão o direito de falar quando considere que suas ideias resultam perigosas ou ofensivas, "então

\footnotetext{
${ }^{649}$ A nível de jurisprudência norte-americana, vale mencionar a famosa decisão acerca do caso Ku Klux Klan, em Brandenburg vs. Ohio, julgado em 1969.

${ }^{650}$ DWORKIN, Ronald. Justice for Hedgehogs. Keynote address. In: Boston University, p. 471-472. Disponível em: < http://www.bu.edu/law/journals-archive/bulr/documents/dworkin_k.pdf>. Acesso em 15 fev. 2015.

${ }^{651}$ DWORKIN, Ronald. Virtud Soberana. La teoría y la práctica de la igualdad. Traducción de Fernando Aguiar y de María Julia Bertomeu. Barcelona: Ediciones Paidós Ibérica S.A., 2003, p. 396-397.
} 
este não é um igual na competição argumentativa do poder". Por derradeiro, deve-se permitir que todos os cidadãos que estão submetidos às leis possuam voz igual no processo que as produz, "ainda quando temos razões para detestar suas convicções ou quando sacrifiquemos nosso direito a impor nossas leis sobre eles". 652

Do postulado da igual consideração e respeito, e do respeito à independência ética, decorre que é preciso ser tolerante com o intolerante. É essa a essência e o valor da democracia. Se não conseguimos deferir tolerância ao intolerante, então como defenderemos a solidariedade em nossa comunidade?

Perguntamos: respeitamos o trunfo da igual consideração e respeito de um cidadão, que merece tratamento enquanto igual membro da sociedade que ele é quando regemos, majoritariamente, um modo de vida que consideramos melhor, porque pessoas que seguem esse bom viver são pessoas melhores? Ao fazer isso, não estamos considerando o diferente, que se destaca por sua diferente opinião, como menos que um homem, por ser pior e detestável? Ora, a escolha de como cada um irá viver, de quais valores e opiniões essenciais ele irá adotar cabe a ele próprio, desde que ele nade em sua própria raia, onde ele nadará como desejar, desde que não transgrida as raias alheias. O discurso do ódio transgride as raias alheias?

A liberdade de expressão configura o distinto rol dos "special rights" que, por sua vez, impõem restrições poderosas ao Estado. Eis o limite dessas liberdades: "government may not infringe that special freedom unless it has what American lawyers have come to call a 'compelling' justification". 653

Logo, o discurso do ódio, assim como todos os direitos, encontra, obviamente, limites. Ele transgride as "raias alheias", devendo ser abreviado em situações emergenciais, a saber: para prevenir um perigo claro, iminente e grave. ${ }^{654}$ Esses são os traços delineados por Dworkin ao hate speech, em sua última obra (Religion Without God).

A concepção dworkineana inevitavelmente agasalha os direitos dos detestáveis. A censura ao livre discurso do ódio configura, sob a ótica de Dworkin, a violação da independência ética. Ora, "nossas convicções a respeito da liberdade de expressão não são provisórias, mornas nem marginais". ${ }^{655}$ São mais que convicções. Na verdade, a

\footnotetext{
${ }^{652}$ DWORKIN, Ronald. Virtud Soberana. La teoría y la práctica de la igualdad. Traducción de Fernando Aguiar y de María Julia Bertomeu. Barcelona: Ediciones Paidós Ibérica S.A., 2003, p. 396-397.

${ }^{653}$ DWORKIN, Ronald. Religion without god. Cambridge, Mass.: Harvard University Press, 2013, p. 131.

${ }^{654}$ DWORKIN, Ronald. Religion without god. Cambridge, Mass.: Harvard University Press, 2013, p. 131-132.

${ }^{655}$ DWORKIN, Ronald. Uma questão de princípio. Título original: A Matter of Principle. Tradução de Luís Carlos Borges. 2. ed. São Paulo: Martins Fontes, 2005, p. 523.
} 
independência ética cintila como um argumento capaz de atender às estratégias baseadas em direitos, e não em objetivos.

Do mesmo modo que livros pornográficos poderiam incitar crimes de violência sexual ou um deletério sobre a economia geral, por causar absenteísmo no trabalho, livros de Shakespeare e a Bíblia também poderiam gerar essas infelizes consequências. Mas estes últimos são amplamente aceitos pela comunidade, que os compreende como aceitáveis dentro de um parâmetro do bem viver.

A censura à liberdade de expressão poderia representar um risco à publicação, por exemplo, de obras de Agatha Christie, "a rainha do crime", por representarem um risco de contaminar os leitores pela sanha homicida de matar seus rivais porque o vilão da história assim o fez. Isso configura um insulto aos cidadãos. Ronald Dworkin afirma, nesse sentido, que "o Estado insulta os seus cidadãos e nega a eles responsabilidade moral, quando decreta que não se pode confiar neles para ouvir opiniões que possam persuadi-los a adotar convicções perigosas ou ofensivas". ${ }^{656}$

Buscamos, e defendemos, portanto, que o esquema de regulamentação do discurso do ódio seja sensato, ou seja, que ele lide com um perigo real, e não com possibilidades mascaradas pelo medo, especulativo, de uma maioria. O risco de que o discurso do ódio gere violência é especulativo, e o Estado não deve trabalhar com experimentos, tentativas, extremas incertezas. Dworkin ressalta ser "arrogância da maioria pressupor que os métodos ortodoxos de expressão sejam as maneiras adequadas de falar, pois isso é uma negação ao direito da igual consideração e respeito". ${ }^{657}$

Portanto, a justificativa utilitarista não logra encontrar sucesso sem recorrer "às preferências moralistas sobre como a minoria deve viver, e o Estado, não obstante, insiste nessa justificativa", formando uma imagem de atuação política, para Dworkin, repulsiva. ${ }^{658}$ Trata-se, afinal, de uma imposição ao sofrimento impingida pela maioria sobre a minoria - e como ela deve viver. Apelos ao bem-estar geral atraem a censura, "a maioria viola o direito do falante ao censurá-lo" "659. É, por isso, uma grande injustiça que alguém que quer falar o que pensa seja amordaçado, detido, censurado ou retardado.

Insistimos em questionar: a restrição deixará alguma pessoa numa condição que se

\footnotetext{
${ }^{656}$ DWORKIN, Ronald. $O$ direito de liberdade: a leitura moral da Constituição americana. Trad. Marcelo Brandão Cipolla. São Paulo: Martins Fontes, 2006, p. 319.

${ }^{657}$ DWORKIN, Ronald. Levando os direitos a sério. Tradução: Nelson Boeira, 3.ed. São Paulo: Editora WMF Martins Fontes, 2010, p. 309.

${ }^{658}$ DWORKIN, Ronald. Uma questão de princípio. Título original: A Matter of Principle. Tradução de Luís Carlos Borges. 2. ed. São Paulo: Martins Fontes, 2005, p. 547.

${ }^{659}$ DWORKIN, Ronald. Uma questão de princípio. Título original: A Matter of Principle. Tradução de Luís Carlos Borges. 2. ed. São Paulo: Martins Fontes, 2005, p. 589.
} 
considera negar a igualdade pela Constituição?

No cenário brasileiro, deparamo-nos com um julgamento histórico enfrentado pelo Supremo Tribunal Federal: o paciente do HC n. 82424/RS, Siegfried Ellwanger, editor gaúcho, que foi acusado de incorrer no crime de "incitar e induzir a discriminação racial", previsto na Lei n. 7.716/89, com a redação da Lei n. 8.081/90, art. 20, caput, que, por sua vez, estabelece pena de reclusão de um a três anos para quem "praticar, induzir ou incitar a discriminação ou preconceito de raça, cor, etnia, religião ou procedência nacional”.

Em 17/9/2003, o Supremo Tribunal Federal concluiu o julgamento do habeas corpus, mantendo a condenação do editor Siegfried Ellwanger a ele imposta pelo Tribunal de Justiça do Rio Grande do Sul por crime de racismo. Por maioria de sete a três, o Plenário negou o recurso, vencidos os ministros Moreira Alves, Marco Aurélio e Carlos Ayres Britto.

De um lado, tínhamos Siegfried Ellwanger, um editor e escritor gaúcho, que publicara obras de sua autoria bem como de outros autores, buscando um suposto revisionismo histórico em torno do Holocausto dos judeus. De outro lado, tínhamos os judeus de todo o país, que se sentiram diminuídos com o que Elwanger escrevera - que o Holocausto não passara de um golpe judaico voltado a ganhar vantagens políticas, econômicas e sociais.

Inicial e aparentemente, colocou-se, enquanto questão central, o questionamento perverso de se os judeus configurariam uma raça ou não, o que esvaziaria o texto constitucional, uma vez que a Genética mais moderna nos mostrou que, biologicamente, raça não existe, se tratando de uma construção social, o que nos levaria à esdrúxula conclusão de que o texto constitucional que veda a prática do racismo jamais poderia ser aplicado, porque teríamos, então, "uma tipificação constitucional de um crime impossível!",660. Nossa Constituição, enquanto projeto aberto para o futuro, proíbe, nitidamente, qualquer espécie de discriminação, seja contra judeus, negros, nordestinos etc. Contudo, o que realmente esteve em jogo durante todo o processo foi exatamente qual a configuração do direito de liberdade de expressão no Texto Constitucional de 1988. Portanto, o que foi objeto de análise pelos aplicadores do direito foi a localização da liberdade de expressão, sua abrangência, seus limites, e o que ela significa em nosso cenário.

É nítido o uso da ponderação de valores como método aclamado pela doutrina e jurisprudência brasileiras como forma de solução de conflitos entre direitos. No caso Ellwanger, não foi diferente. Percebemos que a interpretação dos nossos juízes não se deixou orientar pela única resposta correta, resposta essa que não nos é dada mediante o uso de um

\footnotetext{
${ }^{660}$ OMMATI. José Emílio Medauar. Liberdade de Expressão e Discurso de Ódio na Constituição de 1988. 2.ed.
} Rio de Janeiro: Lumen Juris, 2014, p. 91. 
método, mas construída, e reconstruída, pelos argumentos, de cada caso concreto, dotado de unicidade e de irrepetibilidade, onde se propõe o respeito aos direitos enquanto trunfos.

Assim, o uso do princípio da proporcionalidade impossibilitou o alcance da única decisão correta, uma vez que demanda a perseguição a um método pré-fixado, que em nada garante a verdade, e que não matiza os valores de quem os aplica. Percebemos que, amparando-se do mesmo método, os Ministros Marco Aurélio e Gilmar Mendes chegaram a decisões diametralmente opostas. Como solução a essa deficiência, recorremos, mais uma vez, a Dworkin, tendo em vista que, se o Direito é valor, isso não implica que devo aplicá-lo na maior medida possível em seu grau ótimo, como pretende Alexy, "mas sim que ou o valor vale ou não vale". ${ }^{661}$ A lógica, portanto, é binária, e não múltipla.

Se perquirirmos o caminho proposto por Alexy, deparar-nos-emos diante da tensão conflituosa entre igualdade e liberdade, de modo que os princípios que decorrem desses dois postulados passarão sempre por uma graduação que dificilmente realizará o ideal exigido pela justiça. A crença no método heurístico, insistimos, não é garantia de defesa, não é garantia da verdade. Por outro lado, a única resposta correta é alcançada mediante o esforço interpretativo do juiz, à guisa da Justiça de ouriços.

Diante do caso Ellwanger, quedamo-nos instigados a analisar o espaço que ocupa a liberdade de expressão na modalidade do hate speech em um cenário onde se pretende levar os direitos a sério.

O STF entendeu pelo cumprimento do compromisso histórico exigido pela sociedade brasileira contra o racismo, que foi uma das últimas sociedades, do mundo, a abolir a escravatura, que se ancorava na questão racial, e que viveu, em especial na Era Vargas, inúmeros casos de antissemitismo. Sob tal perspectiva, a história jurídico-institucional brasileira não abre espaço para o discurso do ódio, por se tratar de um discurso racista e discriminatório. Resta-nos impossível a convivência entre o discurso do ódio e as leis antidiscriminatórias.

Recorrendo aos argumentos em prol do bem-estar geral, aqueles que entendem pelo acerto da decisão da nossa Suprema Corte, poderiam concordar com Jeremy Waldron, quando ele considera que o hate speech configura, por si, uma gravidade, um mal, e acrescenta: "the tiny impacts of millions of actions-each apparently inconsiderable in itself-can produce a

\footnotetext{
${ }^{661}$ OMMATI. José Emílio Medauar. Liberdade de Expressão e Discurso de Ódio na Constituição de 1988. 2.ed. Rio de Janeiro: Lumen Juris, 2014, p. 6.
} 
large-scale toxic effect." ${ }^{662}$ Em "The Harm in Hate Speech”, o referido autor argumenta que a liberdade de expressão nos Estados Unidos é tão absoluta, tanto na lei como na opinião pública, que lhes falta regulação significativa contra o discurso do ódio, dirigido a humilhar ou difamar minorias. Baseando-se em investigações legais e históricas, o tratado de Jeremy Waldron consiste, principalmente, em uma defesa filosófica da regulação do hate speech. Ele aponta esse tipo de discurso como um problema ambiental que polui a atmosfera da segurança e da dignidade que a sociedade deve conferir a seus membros ${ }^{663}$.

Já discorremos, na Parte I do presente estudo, acerca da identidade constitucional. Pois bem, é inegável que a inclusão dos indivíduos pressuponha, nas palavras de Habermas, o "igual acesso a relações e tradições sociais constitutivas-de-identidade". ${ }^{664}$

A identidade constitucional contemporânea é conformada, dentre outras coisas, pelo respeito aos direitos fundamentais de igualdade e de liberdade de expressão. Sem dúvida, as decisões constitucionais clamam por referências à identidade nacional e cultural, como é o caso de se decidir se a liberdade de expressão do pensamento envolve ou não o direito a proferir discursos extremistas. ${ }^{665}$

No cenário brasileiro, o discurso do ódio ultrapassaria as barreiras da liberdade de expressão, por se tratar de um discurso violador de direitos. Entender-se-ia, portanto, que a Constituição, de 1988, ao criminalizar a prática de racismo, juntamente à Lei n. 7.716/89, com redação dada pela Lei n. 8.081/90, proibiram o discurso do ódio.

Aqui surge a tipificação do crime de racismo, verdadeiro escudo a ser utilizado na defesa contra essas perversidades, sendo plausivelmente dotado de imprescritibilidade e de inafiançabilidade. A previsão constitucional inserida no art. $5^{\circ}$, incisos XLI e XLII é, portanto, fruto da sinalização de uma tentativa da sociedade brasileira de repudiar o racismo e suas formas discriminatórias. Lembremo-nos que, ao contrário da interpretação restrita dos Ministros Moreira Alves e Marco Aurélio, a história institucional brasileira mostra que não somos apenas intolerantes com os negros, mas também com as mulheres, com os judeus, com

\footnotetext{
${ }^{662}$ WALDRON, Jeremy. The Harm in Hate Speech. Cambridge: Harvard University Press, 2012 apud TOWNSEND, Daniel. Where to Draw the Line on Hate Speech? In: The American Prospect, June, 2012. Disponível em: < http://prospect.org/article/where-draw-line-hate-speech>. Acesso em 15 jan. 2016. ${ }^{663}$ WALDRON, Jeremy. The Harm in Hate Speech. Cambridge: Harvard University Press, 2012 apud TOWNSEND, Daniel. Where to Draw the Line on Hate Speech? In: The American Prospect, June, 2012. Disponível em: < http://prospect.org/article/where-draw-line-hate-speech>. Acesso em 15 jan. 2016. ${ }^{664}$ HABERMAS, Jürgen. Notas sobre a tríade de Denninger: diversidade, segurança e solidariedade. Tradução livre, p. 6. ${ }^{665}$ ROSENFELD, Michel. A identidade do sujeito constitucional. Texto original: The identity of the constitutional subject. In: Cardoso Law Review: A Mentalidade Pós-Moderna e o Direito, Nova Iorque: Yeshiva University Press, p. 1049-1109, Janeiro de 1995. Copyright: Yeshiva University e Michel Rosenfeld, p.3.
} 
os homossexuais, dentre outras minorias, todas merecedoras de igual proteção constitucional e legal.

A Lei n. 7.716/89 criminaliza os atos de racismo utilizando-se de verbos referentes à exclusão, tais como impedir, obstar, recusar, negar, referindo-se ao acesso a ambientes públicos e privados, a estabelecimentos, a atendimentos etc. Posteriormente, o art. 20 incluiu aos quadros do racismo a prática, a indução, ou a incitação da discriminação ou preconceito de raça, cor, etnia, religião ou procedência nacional.

Haveria, então, como compatibilizar o discurso do ódio com a proibição do racismo no cenário brasileiro? Intentemos enquadrar o discurso do ódio ao tipo penal incriminador: o referido discurso mergulha nos verbos (praticar, induzir e incitar) elencados pelo art. 20 da Lei de Discriminação Racial brasileira?

Praticar a discriminação ou o preconceito significa levá-lo a efeito, realizá-lo. A prática do racismo configura, aparentemente, um caso cristalino, como, por exemplo, a recusa de atendimento a negros em uma determinada loja comercial. O problema é que a discriminação segregacionista, nesses casos, acontece, de forma sutil e disfarçada, "transnominada" de termos como, por exemplo, a exigência de "boa aparência" para ocupação de empregos e o "uso de elevadores de serviço" para funcionários. Pois bem, sem a pretensão de adentrar nas formas disfarçadas, e lamentáveis, de discriminação, prossigamos.

Induzir a discriminação ou o preconceito seria persuadir, convencer as pessoas àquele preconceito ou discriminação. Enquanto incitar seria estimular, incentivar, instigar a discriminação ou o preconceito. É na indução e na incitação que se enquadraria o discurso do ódio no contexto brasileiro, que preferiu não correr o risco de pagar o preço do racismo.

A partir do resultado a que chegou o STF, percebemos ser incompatível o hate speech com nossa lei antidiscriminatória. Portanto, José E. Medauar Ommati ${ }^{666}$ encontra, em Dworkin, o que ele chama de "uma contradição interna insanável" acerca da permissibilidade de discursos do ódio, mesmo os mais perversos e racistas, que não podem ser proibidos, em nome da igual consideração e respeito. Para Ommati, “o autor americano, nesse ponto, não conseguiu compreender corretamente a própria história institucional de seu país e as exigências de integridade". ${ }^{667}$ Assim, a ideia de integridade dependeria não apenas da análise da teoria em si, mas, principalmente, da história jurídica e institucional de cada comunidade

\footnotetext{
${ }^{666}$ OMMATI. José Emílio Medauar. Liberdade de Expressão e Discurso de Ódio na Constituição de 1988. 2.ed. Rio de Janeiro: Lumen Juris, 2014, p. 100.

${ }_{667}$ OMMATI. José Emílio Medauar. Liberdade de Expressão e Discurso de Ódio na Constituição de 1988. 2.ed. Rio de Janeiro: Lumen Juris, 2014, p. 97.
} 
de princípios. ${ }^{668}$ No Brasil, não se poderia afirmar, em qualquer hipótese, que a liberdade de expressão seja entendida como a possibilidade de se proferir o discurso do ódio que se configure como racista e discriminatório.

À luz da nossa lei de crimes raciais, praticamente todo discurso do ódio desembocará no racismo, porque compreendemos, majoritariamente, que esse discurso promove, instiga e incita a violência e a discriminação racial, uma vez que traçamos a tênue linha divisória antes do marco do respeito à independência ética, postulado decorrente da igual consideração e respeito.

O que gostaríamos, neste estudo, é, à luz da perspectiva dworkineana, convidar o leitor à busca de uma abertura capaz de superar o medo do risco especulativo que o discurso do ódio pode representar.

Que a censura prévia ao discurso do ódio seja proibida, não se discute. Assim, os discursos do ódio, a priori, não devem ser proibidos, em respeito à exigência do princípio democrático. Assim, "para que um discurso possa ser visto como racista ou discriminador, ele deve passar pelo espaço público" ${ }^{669}$ Posteriormente, se ficar comprovado, pela discussão pública, que esse discurso fere as garantias legais e constitucionais brasileiras, será proibido, e o proferidor, responsabilizado. O que se polemiza, portanto, é a permissibilidade de se conferir espaço a um discurso do ódio, ainda que, depois de proferido, acarrete em um malestar comunitário.

Insistimos que liberdade e igualdade não entram em conflito, mas se complementam, de forma que, se uma determinada liberdade for exigida pelo princípio da igual consideração e respeito, então ela merece reconhecimento, por ter a força de um verdadeiro trunfo contra o Estado.

Ademais, devemos lembrar que a democracia pressupõe mais que o consenso: ela clama pela abertura ao dissenso. Alertemos para o risco de quando uma maioria tenta impor às pessoas o que ela entende por certo ou por errado. A liberdade de expressão é um direito particularmente necessário a um justo e adequado sistema democrático de governo.

Entendemos que a meta a ser perseguida para que logremos a inclusão de minorias, pressuposto crucial para a formação de uma identidade constitucional, pode coadunar-se com a proteção do discurso do ódio. Pois o direito-trunfo à voz igual de cada cidadão não deve ser seletivo. Ora, a voz é igual, independentemente de se configurar uma voz odiosa, ou bondosa.

${ }^{668}$ OMMATI. José Emílio Medauar. Liberdade de Expressão e Discurso de Ódio na Constituição de 1988. 2.ed. Rio de Janeiro: Lumen Juris, 2014, p. 99.

${ }^{669}$ OMMATI. José Emílio Medauar. Liberdade de Expressão e Discurso de Ódio na Constituição de 1988. 2.ed. Rio de Janeiro: Lumen Juris, 2014, p. 100. 
Portanto, a liberdade de expressão é pressuposto da abertura democrática e da igual consideração e respeito que o Estado deve aos seus concidadãos.

A censura ao discurso do ódio configura, em verdade, na censura ao mau caráter de um cidadão, na censura à sua postura detestável diante do apreço de certas vidas. A censura configura, portanto, a tentativa de uma imposição de uma determinada forma de viver, de ser, de bom viver, de controle sobre o outro. Retomando a didática imagem de pessoas a nadarem em suas próprias raias, cada um nada da forma que bem entender, desde que não atravesse a raia do próximo, que é dividida pelos códigos do direito. Entendemos que o discurso do ódio não atravessa as raias alheias.

Assim, o hate speech não somente convive em um cenário que protege as liberdades, como também decorre e se pressupõe em um cenário onde cada indivíduo é tratado com igual consideração e respeito. Eis a reconciliação entre liberdade e igualdade.

É certo que nenhum direito é absoluto, nem mesmo a liberdade de expressão. Não estamos aqui pregando que o discurso do ódio seja ilimitado. Isso não se coadunaria com toda a coerência da teoria dworkineana a qual defendemos.

Lembremo-nos da linha divisória que separa a liberdade de expressão na forma do discurso do ódio e a pretensão abusiva discriminatória racial.

Retomamos, tediosamente, à distinção entre princípios e objetivos. À luz das justificativas de princípio "uma forma específica é necessária para proteger um direito individual que alguém (ou, talvez, um grupo) tenha contra outras pessoas ou contra a sociedade ou contra o governo como um todo". É o caso das leis antidiscriminação. ${ }^{670}$

É importante compreender que a proteção à existência de leis antidiscriminatórias, que decorrem de argumentos de princípio, de modo algum resvala em incoerência com a disposição da liberdade de expressão defendida por Dworkin, incluindo-se, aqui, a livre expressão do discurso do ódio, que também consiste em um argumento de princípio, e pressuposto do respeito à voz igual e à independência ética que todos os indivíduos possuem enquanto verdadeiros trunfos contra o Estado e seus argumentos de política.

Ressalte-se que a existência de leis antidiscriminatórias é exigência do postulado da igual consideração e respeito e isso não implica, necessariamente, na censura ao discurso do ódio. A convivência entre as leis antidiscriminatórias e o discurso do ódio se complementam e se pressupõem a partir da compreensão de onde se encontra o delineamento que as divide.

\footnotetext{
${ }^{670}$ DWORKIN, Ronald. Uma questão de princípio. Título original: A Matter of Principle. Tradução de Luís Carlos Borges. 2. ed. São Paulo: Martins Fontes, 2005, p. 558.
} 
Ora, leis antidiscriminatórias proíbem a discriminação e o preconceito enquanto perigos graves, iminentes e reais. São leis que tipificam condutas como o preconceito na oferta de emprego ou habitação, por exemplo. Essas leis justificam-se em argumentos de princípio, pois "os indivíduos realmente têm um direito de não serem prejudicados na distribuição de recursos importantes porque outros sentem desprezo pela sua raça". Isso é incontestável. Assim, o reinado da igual consideração e respeito atende ao imperativo da inclusão de minorias, na medida em que impõe o igual acesso a todos a ambientes físicos, a oportunidades de emprego, à saúde, e à voz igual, independentemente de sua cor, origem étnica, religião ou não religião, opção sexual. Aqui afirmamos que o direito à voz igual dos detestáveis também se inclui, sem que isso acarrete na exclusão das minorias.

O livro de Ellwanger, reflexo do plano de suas ideias, não cria barreira alguma que impeça, faticamente, o acesso de judeus a ambientes, a recursos, a ofertas de emprego, ao ensino. O risco de que o livro influencie outras pessoas e acarrete em práticas racistas é especulativo. Devemos traçar a linha divisória para a configuração do racismo para além do discurso do ódio, quando este configure uma situação real e iminente.

A decisão obtida a partir do caso Ellwanger é prova de que, o contexto jurídico brasileiro optou por traçar a linha divisória um pouco antes do momento em que o discurso do ódio configura uma violação, de fato, discriminatória. A existência de leis antidiscriminatórias anula a liberdade de expressão na modalidade do discurso do ódio, de forma que ambas não convivem em um mesmo cenário, sendo que a liberdade é anulada pela suposta proteção à igualdade. Sim, suposta, porque a igualdade de minorias não é ultrajada por um discurso resultante do plano de ideias nefastas e odiosas, que não chegam a impedir o acesso fático dessas minorias.

O que almejamos é uma reconciliação entre a liberdade e igualdade, é uma reconciliação entre a proteção contra crimes raciais e a liberdade de expressão, a reconciliação entre leis antidiscriminatórias, que decorrem do postulado da igualdade da mesma forma que decorre a liberdade de expressão, que, por sua vez, não deve ser censurada por um risco especulativo, nem pela repugnância que uma maioria tenha ao pensamento de certas pessoas, pois se essa maioria impõe um modo ético de ser ao detestável, ela também é um risco, pois o desconsidera, por ser detestável, impingindo-lhe menos valia, e, portanto, retirando o significado do respeito à independência ética e à igualdade desse detestável. Nesse sentido, o problema é quando uma voz vale menos que outra por ser detestável. Se isso é válido, então, a ideia de trunfo perde seu sentido.

Permitir o discurso do ódio não nega a plausibilidade nem a exigência de que nossa 
herança histórica clame por uma especial proteção contra discriminações, uma vez que as leis antidiscriminatórias são exigência da dignidade humana e da igual consideração e respeito. Mas, a nosso ver, quando uma lei censura o discurso do ódio como o fez no caso Ellwanger, ela viola a independência ética do editor em nome de uma proteção especulativa da comunidade.

A censura ao discurso do ódio perde em coerência, e é seletiva. O que se quer dizer, com isso, é que, se censuramos a edição de livros que se proponham a um revisionismo histórico e ao vômito de pensamentos detestáveis, porque esses pensamentos impressos em folhas de papel violam os judeus, os negros e, em geral, as minorias, deveríamos também censurar comerciais e publicações internéticas que ridicularizam e diminuem a figura feminina, por exemplo.

Existirão estratégias alternativas políticas para se perseguir qualquer conjunto de metas coletivas para a inclusão social das minorias, como é o caso das políticas afirmativas. Não é restringindo o direito à voz igual, inerente a todo e qualquer cidadão, sem distinções, que alcançaremos o respeito aos negros, aos índios, aos judeus, às mulheres, à população LGBT, aos pobres, e às outras minorias, mas sim mediante políticas de inclusão, de educação, de informação, de solidarização e de conscientização da sociedade como um todo. O melhor é que se dê educação qualificada aos cidadãos para que exerçam por si sós sua avaliação pessoal diante da exposição de determinado dado ou narração de violência.

O preço de emprestar as cores da política ao caso concreto, em detrimento de um direito-trunfo, é desconfigurá-lo enquanto tal.

Portanto, a teoria de Dworkin oferece-nos um verdadeiro tecido unitário, sobre o qual percorremos coerentemente através de fios condutores argumentativos. Por isso, Hércules não é uma metáfora, nem um ideal. É qualquer juiz, advogado, ou cidadão que se esforce para que suas capacidades intelectuais sejam medidas à equiparação das forças físicas de um Hércules, que aceite o Direito, e que o leve a sério, esforçando-se para enxergá-lo à sua melhor luz. ${ }^{671}$

É o caso de analisarmos se o nosso contexto pertencente ao paradigma vivido por este dado momento, está preparado para admitir a ressignificação da importância que a liberdade de expressão ocupa na comunidade de princípios. Parece-me que não.

${ }^{671}$ Cf. DWORKIN, Ronald. A Justiça de Toga. São Paulo: Martins Fontes, 2010. 


\section{REFERÊNCIAS BIBLIOGRÁFICAS}

ALEXY, Robert. Balancing, constitutional review, and representation. International Journal of constitutional Law. Oxford University Press e New York University School of Law, 2005. v. 3. n. 4.

Palestra proferida na Fundação Casa de Rui Barbosa. Rio de Janeiro, em 10/12/98, apud Ministro Gilmar Mendes, nos autos do HC 82.424/RS, p. 71. In: SUPREMO TRIBUNAL FEDERAL. Crime de Racismo e Anti-Semitismo: Um Julgamento Histórico do STF (Habeas Corpus n. 82.424/RS). Brasília: Brasília Jurídica, 2004.

. Sistema jurídico, principios jurídicos y razón práctica. In: ALEXY, Robert. Derecho y razón práctica.Traducción de Manuel Atienza. México: Fontamara, 1993.

.Teoria dos Direitos Fundamentais (2 ${ }^{\mathrm{a}}$ ed.). Tradução de Virgílio Afonso da Silva da $5^{\text {a }}$ edição alemã Theorie der Grundrechte. São Paulo: Malheiros Editores, 2009.

ALFONSO, Luciano Parejo. El contenido esencial de los derechos fundamentales en la jurisprudencia constitucional. A propósito de la sentencia del Tribunal Constitucional del 8 de abril de 1981. Revista Española de Derecho Constitucional, Vol. I, N 3, Madrid, 1981.

ANDRADE, José Carlos Vieira. Os direitos fundamentais na Constituição portuguesa de 1976. Coimbra: Livraria Almedina, 1998.

ATALIBA, Geraldo. República e Constituição. São Paulo: Malheiros, 1985.

ÁVILA, Humberto. Neoconstitucionalismo: entre a ciência do direito e o direito da ciência. In: SOUZA NETO, Cláudio Pereira de; SARMENTO, Daniel; BINENBOJM, Gustavo (Org.). Vinte anos da Constituição Federal de 1988.

ÁVILA, Humberto. Teoria dos princípios. 11.ed. São Paulo: Malheiros, 2010.

AZEVEDO, Damião Alves de. Ao encontro dos princípios: crítica à proporcionalidade como solução aos casos de conflito aparente de normas jurídicas, Pós-graduação lato sensu em Direito Público, 2008, p. 16. Disponível em: <http://moodle.cead.unb.br/agu/course/view.php?id=9>.

BACIGALUPO, Mariano. La aplicación de la doctrina de los "límites inmanentes" a los derechos fundamentales sometidos a reserva de limitación legal (A propósito de la sentencia del Tribunal Administrativo Federal alemán de 18 de octubre de 1990).In: Revista Española de Derecho Constitucional, Madrid, a. 13, mayo/ago., 1993.

BANDEIRA DE MELLO, Celso Antônio. Elementos de direito administrativo. São Paulo: Revista dos Tribunais, 1986.

BARAK, Aharon. Proportionality: Constitutional Rights and their Limitations. Cambridge: Cambridge University Press, 2012.

BARCELLOS, Ana Paula de. A eficácia jurídica dos princípios constitucionais: o princípio da dignidade da pessoa humana. Rio de Janeiro: Renovar, 2002. 
BARCELLOS, Ana Paula. Ponderação, racionalidade e atividade jurisdicional. Rio de Janeiro: Renovar, 2005, p. 186-187; BARROSO, Luís Roberto. Curso de direito constitucional contemporâneo: os conceitos fundamentais e a construção do novo modelo. 2. Ed. São Paulo: Saraiva, 2010.

BARROSO, Luís Roberto. JURISDIÇÃO CONSTITUCIONAL: A TÊNUE FRONTEIRA ENTRE $O$ DIREITO $E$ A POLÍTICA. Disponível em: <http://www.luisrobertobarroso.com.br/?p=1000>. Acesso em: 2 mar. 2014.

BERLIN, Isaiah. Two Concepts of Liberty (1958). In: Liberty (Oxford University Press, Oxford 2002).

BERNAL PULIDO, Carlos. El principio de proporcionalidad y los derechos fundamentales. 3.ed. Madrid: Centro de Estudios Constitucionales, 2007.

BONAVIDES, Paulo. Curso de direito constitucional. 8. ed. São Paulo: Malheiros, 1999.

BOMHOFF, Jacco. Balancing Constitutional Rights: The Origins and Meanings of Postwar Legal Discourse. Cambridge University Press.

BOROWSKI, Martin. La restricción de los derechos fundamentales. In: Revista Española de Derecho Constitucional, Madrid, a. 20, n. 59, mayo/ago., 2000, p. 56 e ss.

BRANCO, Paulo Gustavo Gonet. Juízo de ponderação na jurisdição constitucional. São Paulo: Saraiva, 2009.

CAMAZANO, Joaquín Brage. Los Límites a los Derechos Fundamentales. Madrid: Dylinson, 2004.

CANARIS, Claus Wilhelm. Pensamento sistemático e conceito de sistema na ciência do direito. Tradução de A, Menezes Cordeiro. Lisboa: Fundação Calouste Gulbenkian, 1989, p. 76-102.

CANOTILHO, J. J. Gomes; MACHADO, Jónatas E. M.. Constituição e código civil brasileiro: âmbito de proteção de biografias não autorizadas. In: JÚNIOR, Antônio Pereira Gaio; SANTOS, Márcio Gil Tostes dos. Constituição Brasileira de 1988. Reflexões em comemoração ao seu $25^{\circ}$ aniversário. Curitiba: Juruá, 2014.

CANOTILHO, José Joaquim Gomes. Direito constitucional e teoria da Constituição. Coimbra: Almedina, 2003.

CARA, Juan Carlos Gavara de. Derechos Fundamentales y Desarrollo Legislativo. La garantía del contenido esencial de los derechos fundamentales en la Ley Fundamental de Bonn. Madrid: Centro de Estudios Constitucionales, 1994.

CARVALHO NETTO, Menelick de; SCOTTI, Guilherme. Os Direitos Fundamentais e a (in) certeza do Direito: a produtividade das tensões principiológicas e a superação do sistema de regras. Belo Horizonte: Editora Fórum, 2011. 
CHEQUER, Cláudio. A liberdade de expressão como direito fundamental preferencial prima facie: análise crítica e proposta de revisão ao padrão jurisprudencial brasileiro. Rio de Janeiro: Lumen Juris, 2011.

COSTA NETO, João. Dignidade humana. Visão do Tribunal Constitucional Federal Alemão, do STF e do Tribunal Europeu. São Paulo: Saraiva, 2014.

COSTA NETO, João. Entre Cila e Caríbdis: a liberdade de expressão em meio ao conflito entre a discricionariedade do Legislador e a intensidade do controle exercido pelo Juiz Constitucional. São Paulo: Saraiva, no prelo.

DECLARAÇÃO UNIVERSAL DOS DIREITOS DO HOMEM. Disponível em: $<$ http://www.humanrights.com/pt/what-are-human-rights/universal-declaration-of-humanrights.html>. Acesso em 20 dez. 2015.

DESANTES GUANTER, José María; SORÍA, Carlos. Los límites de la información: la información en la jurisprudencia del Tribunal Constitucional, las 100 primeras sentencias. Madrid: Asociación de Prensa de Madrid, 1991.

DEUTSCHER BUNDESTAG. Lei Fundamental da República Federal da Alemanha. Disponível em: < https://www.btg-bestellservice.de/pdf/80208000.pdf> . Acesso em 5 out. 2015.

DWORKIN, Ronald. A Justiça de Toga. São Paulo: Martins Fontes, 2010.

. A matter of principle. Harvard University Press, 1985, p. 69-71.

. A raposa e o porco-espinho: justiça e valor. Tradução de Marcelo Brandão Cipolla. São Paulo: Editora WMF Martins Fontes, 2014, p. 180.

. Do liberty and equality conflict? In: BARKER, Paul. Living as equals, p.39-58; DWORKIN, Ronald. Moral Pluralism. In: DWORKIN, Ronald. Justice in Robes.

. Justice for Hedgehogs. Cambridge, MA: Harvard University Press.

. Justice for Hedgehogs. Keynote address. In: Boston University. Disponível em: < http://www.bu.edu/law/journals-archive/bulr/documents/dworkin_k.pdf>. Acesso em 15 fev. 2015.

. Law's Empire. Cambridge: Harvard University Press, 1986.

. Levando os direitos a sério. Tradução: Nelson Boeira, 3.ed. São Paulo: Editora WMF Martins Fontes, 2010.

. O direito de liberdade: a leitura moral da Constituição americana. Trad. Marcelo Brandão Cipolla. São Paulo: Martins Fontes, 2006.

2013.

. Religion without god. Cambridge, Mass.: Harvard University Press, 
. Sovereign Virtue: The Theory and Practice of Equallity. Cambridge; London: Harvard University Press, 2000.

.Taking Rights Seriously. Cambridge: Harvard University Press, 1977.

Review. Vol. 59, 1992.

The concept of non enumerated rights. In: University of Chicago Law

. Uma questão de princípio. Título original: A Matter of Principle. Tradução de Luís Carlos Borges. 2. ed. São Paulo: Martins Fontes, 2005.

.Virtud Soberana. La teoría y la práctica de la igualdad. Traducción de Fernando Aguiar y de María Julia Bertomeu. Barcelona: Ediciones Paidós Ibérica S.A., 2003.

ELSTER, John. Juicios salomónicos. Las limitaciones de la racionalidad como principio de decisión (traducción de Carlos Gardini). Gedisa, Barcelona, 1999.

ECHAVARRIA, Juan Jose Solozabal. Algunas questiones básicas de la teoría de los derechos fundamentales. In: Revista de Estudios Políticos. Nueva Época: Madrid, n. 71, p. 98, ene./mar. 1991.

ESPÍNDOLA, Ruy Samuel. Conceito de princípios constitucionais: elementos teóricos para uma formulação dogmática adequada. 1999.

FARIAS, Cristiano Chaves de; ROSENVALD, Nelson. Curso de Direito Civil. Parte Geral e LINDB. Vol. 1. 13. ed. 2015.

FISS, Owen. A Ironia da Liberdade de Expressão: Estado, Regulação e Diversidade na Esfera Pública. Rio de Janeiro: Editora Renovar, 2005.

GADAMER, Hans-George. Verdad y Método. Tradução por Ana Agud Aparicio y Rafael de Agapino. Salamanca: Sígueme, 1977.

GARCIA, Emerson. Conflito entre normas constitucionais: esboço de uma teoria geral. Rio de Janeiro: Lumen Juris, 2008.

GRAU, Eros Roberto. A ordem econômica na Constituição de 1988: interpretação e crítica, 2. ed. São Paulo: Revista dos Tribunais, 1990.

GÜNTHER, Klaus. Teoria da argumentação no direito e na moral: justificação e aplicação. Tradução de Cláudio Molz. São Paulo: Landy, 2004.

GÜNTHER, Klaus. Uma concepção normativa de coerência para uma teoria discursiva da argumentação jurídica. Cadernos de Filosofia Alemã, n. 06, São Paulo, 2000.

HÄBERLE, Peter. La garantía del contenido esencial de los derechos fundamentales en la ley fundamental de Bonn. Una contribución a la concepción institucional de los derechos fundamentales y a la teoría de la reserva de la ley. Madrid: Dykinson-Constitucional, 2003. 
HABERMAS, Jürgen. A Inclusão do Outro: estudos de teoria política. São Paulo: Loyola, 2002.

HABERMAS, Jürgen. Direito e democracia: entre facticidade e validade, vol. I, 2.ed., tradução: Flávio Beno Siebeneichler. Rio de Janeiro: Tempo Brasileiro, 2012.

HABERMAS, Jürgen. Notas sobre a tríade de Denninger: diversidade, segurança e solidariedade. Tradução provisória de Menelick Carvalho Netto, da tradução de Christopher Long e William Scheuerman. In: Revista Constellations, vol. 07, n. 4, 2000.

HABERMAS, Jürgen. Reply to symposium participants - Benjamin N. Cardoso School of Law. Cardozo Law Review, v. 17, março de 1996.

HART, H.L.A. Law, Liberty, and Morality. Stanford University Press, 1963.

HART, H.L.A (1961). The Concept of Law. Oxford University Press: Oxford, 2012.

HESSE,Konrad. La interpretación de la Constitución. In: HESSE,Konrad. Escritos de derecho constitucional. Traducción de Pedro Cruz Villalón. 2. Ed. Madrid: Centro de Estudios Constitucionales, 1992, p. 45-46.

HOLMES, Stephen e SUSTEIN, Cass. El Costo de los Derechos: Por qué la libertad depende de los impuestos. Buenos Aires: Siglo XXI Editores, 2011.

INFORMATIVO STF $\mathrm{N}^{\circ}$ 369. HC n. 84219/SP, rel. Min. Marco Aurélio, 9.11.2004. Disponível em: <http://www.stf.jus.br/arquivo/informativo/documento/informativo369.htm>. Acesso em 2 dez. 2015.

KELSEN, Hans. Teoria pura do direito, 5.ed., p. 463-473 apud SOUZA NETO, Cláudio Pereira de; SARMENTO, Daniel. Direito Constitucional: Teoria, história e métodos de trabalho. 2. ed. Belo Horizonte: Fórum, 2014.

KLATT, Matthias; MEISTER, Moritz. The Constitutional Structure of Proportionality. Oxford: Oxford University Press, 2012.

KOMMERS, Donald P. The constitutional jurisprudence of the Federal Republic of Germany. $3^{\text {rd }}$ ed., rev and expanded.

KRIELE, Martin. Introducción a la teoría del Estado. Fundamentos históricos de la Legitimidad del Estado Constitucional Democrático. Traducción por Eugenio Bulygin. Buenos Aires: De Palma, 1980.

LIMA, Lucas Correia de. Hitler censurado!. In: Mega Jurídico. Disponível em: < http://www.megajuridico.com/hitler-censurado/>. Acesso em fev. 2016.

LOPERA MESA, Gloria-Patricia. El principio de proporcionalidad y los dilemas del constitucionalismo. Comentario al libro de CARLOS BERNAL PULIDO: El principio de proporcionalidad y los derechos fundamentales, Madrid, Centro de Estudios Políticos y Constitucionales, 2003. In: Revista Española de Derecho Constitucional, Nueva Época, ISSN: 0211-5743, n. 73, enero-abril (2005). 
MARINONI, Luiz Guilherme. MITIDIERO, Daniel. Curso de Direito Constitucional. 3.ed. São Paulo: Revista dos Tribunais, 2014.

MARQUES, Raphael Peixoto de Paula. Teoria dos direitos fundamentais e argumentação jurídica: reconstruindo o debate entre Jürgen Habermas e Robert Alexy. Disponível em: < www.agu.gov.br/page/download/index/id/13836048>. Acesso em 20 out.

MARRAFON, Marco Aurélio. Texto constitucional não é norma, mas vincula. Disponível em: <http://www.conjur.com.br/2015-dez-28/constituicao-poder-texto-constitucional-naonorma-vincula $>$. Acesso em 3 jan. 2016.

MARTÍN-RETORTILLO BAQUER, Lorenzo; OTTO Y PARDO, Ignacio. Derechos fundamentales y Constitución. Madrid: Editorial Civitas S.A., 1992, p. 110.

MEDINA GUERRERO, Manuel. La vinculación negativa del legislador a los derechos fundamentales. Madrid: Ciencias Jurídicas, 1996, p. 93.

MEYER-PFLUG, Samantha Ribeiro. Liberdade de expressão e discurso do ódio. São Paulo: Editora Revista dos Tribunais, 2009.

MÜLLER, Friedrich. Tesis acerca de la estructura de las normas jurídicas. Traducción de Luis Villacorta Mancebo. Revista Española de Derecho Constitucional. Año 9. N. 27. Septiembre-Diciembre, 1989, p. p. 125.

NEVES, MARCELO. Entre Hidra e Hércules: princípios e regras constitucionais como diferença paradoxal do sistema jurídico. São Paulo: Editora WMF Martins Fontes, 2013.

OMMATI. José Emílio Medauar. Liberdade de Expressão e Discurso de Ódio na Constituição de 1988. 2.ed. Rio de Janeiro: Lumen Juris, 2014.

PEDRON, Flávio Quinaud. A contribuição e os limites da teoria de Klaus Günther: A distinção entre discursos de justificação e discursos de aplicação como fundamento para uma reconstrução da função jurisdicional. Disponível em: $<$ http://dspace/xmlui/bitstream/item/6243/Biblioteca\%20Digital\%20-

$\%$ 20Editora\%20F\%C3\%B3rum.pdf?sequence=1>. Acesso em 10 out. 2015.

PEREIRA, Jane Reis Gonçalves. Interpretação constitucional e direitos fundamentais. Rio de Janeiro: Renovar, 2006.

PODER JUDICIÁRIO DO ESTADO DO RIO DE JANEIRO, JUÍZO DE DIREITO DA $33^{\mathrm{a}}$ VARA CRIMINAL DA CAPITAL. Decisão. Disponível em: <http://s.conjur.com.br/dl/livrohitler-rj.pdf>. Acesso em fev. 2016.

PULIDO, Carlos Bernal. El principio de proporcionalidad y los derechos fundamentales. Madrid: Centro de Estudios Políticos y Constitucionales, 2003.

PULIDO, Carlos Bernal. La Racionalidad de la Ponderación. In: Revista Española de Derecho Constitucional, ISSN: 0211-5743, n. 77, mayo-agosto, 2006. 
RAWLS, John. The Basic Liberties and Their Priority. In: ID.: The Tanner Lectures on Human Values, Salt Lake City, 1983.

REIS NOVAIS, Jorge. Direitos Fundamentais e Justiça Constitucional em Estado de Direito Democrático. Coimbra: Coimbra Editora, 2012.

ROSENFELD, Michel. A identidade do sujeito constitucional. Texto original: The identity of the constitutional subject. In: Cardoso Law Review: A Mentalidade Pós-Moderna e o Direito, Nova Iorque: Yeshiva University Press, p. 1049-1109, Janeiro de 1995. Copyright: Yeshiva University e Michel Rosenfeld.

SARLET, Ingo Wolfgang. Direitos Fundamentais em espécie. In: SARLET, Ingo Wolfgang,

SARMENTO, Daniel. Ubiquidade constitucional: os dois lados da moeda. In: SARMENTO, Daniel. Livres e iguais: estudos de direito constitucional, p. 198-204; BARCELLOS, Ana Paula de. $O$ direito constitucional em 2006. Revista de Direito do Estado, n. 5.

SARMENTO, Daniel. A ponderação de interesses na Constituição Federal. Rio de Janeiro: Lumen Juris, 1999.

SEGADO, Francisco Fernández. La dogmática de los derechos humanos. Lima: Ediciones Jurídicas, 1994.

SEGADO, Francisco Fernández. La teoría jurídica de los derechos fundamentales en la doctrina constitucional. In: "Revista Española de Derecho Constitucional", Madrid, n. 39, Septiembre/Diciembre, 1993, p. 242 e ss. Disponível em: < http://www.cepc.gob.es/gl/publicaci\%C3\%B3ns/revistas/revistas-

electronicas?IDR=6\&IDN=341\&IDA=25145 >. Acesso em 4 nov. 2014.

SERNA, Pedro; TOLLER, Fernando. La Interpretación Constitucional de Los Derechos Fundamentales. Una alternativa a los Conflictos de Derechos. Buenos Aires: La Ley, 200.

SILVA, Virgílio Afonso da. Comparing the Incommensurable: Constitutional Principles, Balancing and Rational Decision. Oxford Journal of Legal Studies, n. 31, p. 273-301, 2011.

SILVA, Virgílio Afonso da. Interpretação constitucional e sincretismo metodológico. In: SILVA, Virgílio Afonso da (Org.) Interpretação Constitucional. Rio de Janeiro: Malheiros, 2005.

SILVA, Virgílio Afonso da. Princípios e regras: mitos e equívocos acerca de uma distinção. In: Revista Latino Americana de Estudos Constitucionais, n. 1, 2003.

STEINMETZ, Wilson Antônio. Colisão de direitos fundamentais e o princípio da proporcionalidade. Porto Alegre: Livraria do Advogado, 2001.

STRECK, Lenio. Jurisdição constitucional e hermenêutica: uma nova crítica do direito. 2 ed. Rio de Janeiro: Forense, 2004. p. 246 apud MARRAFON, Marco Aurélio. Texto constitucional não é norma, mas vincula. Disponível em: <http://www.conjur.com.br/2015dez-28/constituicao-poder-texto-constitucional-nao-norma-vincula >. Acesso em 3 jan. 2016. 
SOUZA NETO, Cláudio Pereira de; SARMENTO, Daniel. Direito Constitucional: Teoria, história e métodos de trabalho. 2. ed. Belo Horizonte: Fórum, 2014.

SUPREMO TRIBUNAL FEDERAL. Ação Direta de Inconstitucionalidade n. 4.815 Distrito Federal. Relatora: Min. Carmen Lúcia. Disponível em: < http://www.stf.jus.br/arquivo/cms/noticiaNoticiaStf/anexo/ADI4815relatora.pdf $>$. Acesso em 26 mai.2015.

SUPREMO TRIBUNAL FEDERAL. Crime de Racismo e Anti-Semitismo: Um Julgamento Histórico do STF (Habeas Corpus n. 82.424/RS). Brasília: Brasília Jurídica, 2004.

SUPREMO TRIBUNAL FEDERAL. STF nega Habeas Corpus a editor de livros condenado por racismo contra judeus. Disponível em: http://www.stf.jus.br/portal/cms/verNoticiaDetalhe.asp?idConteudo=61291\&caixaBusca=N $>$. Acesso em 15 fev. 2015.

TOWNSEND, Daniel. Where to Draw the Line on Hate Speech? In: The American Prospect, June, 2012. Disponível em: < http://prospect.org/article/where-draw-line-hate-speech>. Acesso em 15 jan. 2016.

WALDRON, Jeremy. The Harm in Hate Speech. Cambridge: Harvard University Press, 2012.

WEBBER, Grégoire C. N.. The Negotiable Constitution: On the Limitation of Rights. New York: Cambridge University Press, 2009.

ZEKOLL, Joaquim; REIMANN, Mathias. Introduction to German Law. 2nd ed. Washington: Kluwer Law International, 2005. 